RICARDO DE SOUZA VIEIRA

HOMOPARENTALIDADE:

\title{
ESTUDO PSICANALÍTICO SOBRE PAPÉIS E
ES PARENTAIS EM CASAIS HOMOSSEXUAIS COM \\ ESTUDO PSICANALÍTICO SOBRE PAPÉIS E
FUNÇÕES PARENTAIS EM CASAIS HOMOSSEXUAIS COM FILHOS
}

Dissertação apresentada ao Departamento de Psicologia Clínica do Instituto de Psicologia da Universidade de São Paulo como parte dos requisitos necessários à obtenção do título de Mestre em Psicologia Clínica - versão original.

Área de Concentração: Psicologia Clínica.

Orientadora: Profa. Dra. Maria Lúcia de Araújo Andrade. 
AUTORIZO A DIVULGAÇÃO OU REPRODUÇÃO TOTAL OU PARCIAL DESTE TRABALHO, POR QUALQUER MEIO CONVENCIONAL OU ELETRÔNICO, PARA FINS DE ESTUDO E PESQUISA, DESDE QUE CITADA A FONTE.

Catalogação na publicação

Biblioteca Dante Moreira Leite

Instituto de Psicologia da Universidade de São Paulo

VIEIRA, Ricardo de Souza.

Homoparentalidade: estudo psicanalítico sobre papéis e funções parentais em casais homossexuais com filhos. / Ricardo de Souza Vieira; orientadora Maria Lúcia de Araújo Andrade. - São Paulo: IP - USP, 2011.

206 p.

Dissertação (Mestrado - Programa de Pós-graduação em Psicologia. Área de Concentração: Psicologia Clínica) - Universidade de São Paulo - Instituto de Psicologia

1.Homossexualidade 2.Funções Parentais 3.Família 4. Psicanálise
I. USP/IP
II. Título. 


\section{RICARDO DE SOUZA VIEIRA}

Homoparentalidade: estudo psicanalítico sobre papéis e funções parentais em casais homossexuais com filhos.

Dissertação apresentada ao Departamento de Psicologia Clínica do Instituto de Psicologia da Universidade de São Paulo como parte dos requisitos necessários à obtenção do título de Mestre em Psicologia Clínica - versão original.

Área de Concentração: Psicologia Clínica.

Orientador: Profa. Dra. Maria Lúcia de Araújo Andrade.

Aprovado em:

\section{Banca Examinadora}

Prof. Dr.

Instituição:

Ass.:

Prof. Dr.

Instituição:

Ass.:

Prof. Dr.

Instituição:

Ass.:

SÃO PAULO

2011 
Aos meus pais,

E a Antonio, pelo companheirismo e compreensão nos momentos de ausência. 
AGRADECIMENTOS

À Profa Maria Lúcia Araújo Andrade,
pela paciência, atenção e incentivo.

Ao Prof. Andrés Eduardo Aguirre Antúnez, por ter gentilmente aceitado participar do Exame de Qualificação num momento delicado, e com relevante contribuição, e por aceitar participar desta Banca Examinadora.

Ao Prof. Fernando Carlos Santaella Megale, pela participação na Banca Examinadora.

À Prof ${ }^{a}$ Silvia Maria Alessandri Barile, pela atenciosa leitura e apontamentos relevantes na qualificação.

E a todos que me auxiliaram direta e indiretamente na elaboração deste trabalho. 


\section{RESUMO}

VIEIRA, R. S. - Homoparentalidade - estudo psicanalítico sobre papéis e funções parentais em casais homossexuais com filhos. 2011. 206 p. Dissertação (Mestrado) - Instituto de Psicologia, Universidade de São Paulo, São Paulo, 2011.

Mudanças ocorreram na composição familiar, surgindo as famílias homoparentais, ou seja, casais de pessoas de mesmo sexo que criam filhos. Diante dessa nova realidade cada vez mais visível, tornam-se necessárias a revisão e reconsideração dos conceitos de maternidade e paternidade. Dessa forma, o presente trabalho visa o estudo da homoparentalidade, examinando de que forma os papéis e funções parentais vêm sendo partilhados e regulados pelos membros do casal de pessoas de mesmo sexo que criam filhos. Para tal, foi utilizado o referencial teórico da Psicanálise em Freud e Lacan. Além disso, buscou-se aporte em estudos socioantropológicos da sexualidade, a partir da articulação teórica dos conceitos de homossexualidade, família tradicional e homoparental, função materna e paterna do ponto de vista psicanalítico e sua diferença em relação aos papéis (sociais) parentais. Papel e função parental foram as categorias eleitas para análise de fragmentos de discursos de homossexuais com filhos, colhidos em um estudo socioantropológico.

Palavras-chave: Homossexualidade, Funções Parentais, Família, Psicanálise. 


\begin{abstract}
VIEIRA, R. S. - Homoparenthood - psychoanalytic study on parental roles and homosexual couples with children. 2011. 206 p. Dissertation (Master's Degree) Instituto de Psicologia, Universidade de São Paulo, São Paulo, 2011.
\end{abstract}

Changes have occurred in household composition, the emerging same-sex families, or same-sex couples raising children. Given this new reality increasingly visible, become necessary to review and reconsideration of concepts of motherhood and fatherhood. Thus, this research aims at studying the homoparenthood, examining how parental roles and functions are being shared and regulated by the members of the pair of same-sex couples raising children. To this end, we used the theoretical framework of psychoanalysis in Freud and Lacan. In addition, we sought input from socioanthropological studies on sexuality, from the theoretical articulation of the concepts of homosexuality, traditional and homoparental family, maternal and paternal functions of the psychoanalytic point of view and its difference in relation to the roles (social) parents. Parental role and function categories were chosen for analysis of fragments of speeches by homosexual persons with children, gathered in a socio-anthropological study.

Keywords: Homosexuality, Parental Roles, Family, Psychoanalysis. 


\section{SUMÁRIO}

INTRODUÇÃO

1: HOMOSSEXUALIDADE: UMA CATEGORIA PSICOSSOCIAL

1.1: HISTÓRICO (BREVE) DA HOMOSSEXUALIDADE. DA MALDIÇÃO À CONSTITUIÇÃO DE UMA IDENTIDADE.

1.2: A IDENTIDADE HOMOSSEXUAL SOB ENFOQUE SOCIOANTROPOLÓGICO E SUA ARTICULAÇÃO COM A IDENTIDADE DE GÊNERO.

1.3: AS HOMOSSEXUALIDADES VISTAS PELA PSICANÁLISE. O PROBLEMA DO CONCEITO DE IDENTIDADE EM PSICANÁLISE.

2: A CONSTITUIÇÃO DO SUJEITO DESEJANTE: O COMPLEXO DE ÉDIPO EM FREUD E LACAN E A TEORIA DA SEXUAÇÃO

2.1: SOBRE O CONCEITO DE SEXUALIDADE EM PSICANÁLISE

2.2: ÉDIPO EM FREUD E LACAN

2.2.1: O Complexo de Édipo em Freud

2.2.2: O Édipo em Lacan

2.3: A TEORIA DA SEXUAÇÃO EM LACAN

2.4: CONSIDERAÇÕES SOBRE O ÉDIPO, A TEORIA DA SEXUAÇÃO E A DIFERENÇA SEXUAL

3: FAMÍLIA: ASPECTOS HISTÓRICO, SOCIOANTROPOLÓGICO E PSICANALÍTICO

3.1: ASPECTOS HISTÓRICO E SOCIOANTROPOLÓGICO DA INSTITUIÇÃO FAMILIAR 
3.2: A INSTITUIÇÃO FAMILIAR SOB ENFOQUE PSICANALÍTICO

4: FAMÍLIA HOMOPARENTAL - POSIÇÕES PSICANALÍTICAS E SOCIOANTROPOLÓGICAS

4.1: A FAMILIA HOMOPARENTAL: BREVE HISTÓRICO POLÍTICO DE UM "NOVO" FENÔMENO DA CULTURA HODIERNA

4.2: "FAMÍLIA HOMOPARENTAL": A DESIGNAÇÃO E SUA FORMAÇÃO

4.3: O DEBATE SOCIOPOLÍTICO E JURÍDICO A RESPEITO DA FAMÍLIA

HOMOPARENTAL: UMA LUTA CONTRA A HOMOFOBIA

4.3.1: O Debate no Campo Jurídico

5: FUNÇÕES PARENTAIS EM PSICANÁLISE - A DIFERENÇA ENTRE PAPÉIS E FUNÇÕES MATERNA E PATERNA

5.1: A FUNÇÃO MATERNA E A MÃE-MULHER

5.2: O PAPEL DE PAI, A FUNÇÃO PATERNA E O PAI-SINTOMA 138

6: FUNÇÕES PATERNA E MATERNA NA HOMOPARENTALIDADE

6.1: PESQUISA SOBRE OS PAPÉIS PARENTAIS COM CASAIS HOMOPARENTAIS

6.2: IDENTIDADE SEXUAL, PATERNIDADE E MATERNIDADE 168

6.2.1: A Paternidade Homossexual 168

6.2.2: Maternidade Homossexual 175

6.2.3: A Desproteção Legal 178

6.2.4: Buscando o Reconhecimento Social 181

CONSIDERAÇÕES FINAIS 188

REFERÊNCIAS 197 


\section{INTRODUÇÃO}

Atualmente vê-se que a organização tradicional de família tem sido afetada tanto pelas questões macrossociais e políticas, como pelos avanços tecnológicos. Mudanças ocorreram na composição das famílias a ponto de se poder afirmar que enfrentamos uma crise em sua concepção. (ROUDINESCO ${ }^{1}, 2003$ ). Com o advento do divórcio, as famílias se reconfiguram nas chamadas famílias recompostas, ou ainda, em famílias monoparentais quando só um dos pais, geralmente a mãe, convive com o(s) filho(s). Somadas a essas alterações na configuração familiar, surgem ainda as famílias formadas por pais homossexuais, ou seja, por pares de pessoas de mesmo sexo que criam filhos.

Pode-se questionar de que forma homossexuais podem exercer a parentalidade. Segundo Zambrano ${ }^{2}$, estão descritas na literatura quatro formas principais de acesso à homoparentalidade. A primeira delas é por filhos havidos em uma ligação heterossexual anterior. Depois do rompimento da união, o pai ou a mãe (ou ambos) podem estabelecer uma relação com parceiro/a do mesmo sexo, constituindo assim uma nova família. A nova configuração será considerada um tipo de família recomposta, cuja especificidade é o contexto homoparental.

A segunda maneira é pela adoção, podendo ser legal ou informal. Atualmente, a adoção legal por homossexuais é buscada, na maioria das vezes, individualmente. Existe o temor da recusa se o pedido for feito pelo casal, quando ficaria explicitada a homossexualidade. A adoção legal implica o estabelecimento de um vínculo de filiação irrevogável, unindo o adulto adotante e a criança adotada, com os direitos e deveres daí decorrentes. Quando a adoção é informal, não estabelece vinculação legal entre os participantes, apenas vínculos afetivos, sem os direitos de filiação.

Uma terceira forma é a busca de filhos pelo uso de novas tecnologias reprodutivas, possibilitando o nascimento de filhos biológicos. O método mais utilizado

\footnotetext{
${ }^{1}$ ROUDINESCO, E. - A Família em desordem. RJ: Jorge Zahar, 2003.

2 ZAMBRANO, E. "Parentalidades 'impensáveis': pais/mães homossexuais, travestis e transexuais". In Revista. Horizontes antropológicos. Direitos sexuais. Porto Alegre, ano 12, n. 16, jul/dez, 2006.
} 
pelas mulheres lésbicas é a inseminação artificial ou fertilização medicamente assistida. Pode ser com doador conhecido, geralmente um amigo gay, ou doador desconhecido, através de um banco de esperma. Os homens gays que quiserem filho biológico sem relação sexual com uma mulher têm de fazer uso da "barriga de aluguel", procedimento considerado ilegal no Brasil. Nesses casos, se for cumprido o anteriormente combinado com o pai, a mãe entregará a ele o filho recém-nascido e abrirá mão dos direitos e vínculos legais com a criança.

Finalmente, a quarta possibilidade é a chamada co-parentalidade, na qual os cuidados cotidianos são exercidos de forma conjunta e igualitária pelos parceiros, podendo aparecer entrelaçada com as formas de acesso citadas anteriormente. A parceria pode dar-se pelo planejamento conjunto do casal homossexual, no qual os parceiros decidem pela adoção de uma criança ou pelo uso de novas tecnologias reprodutivas para formar uma família, sendo a parentalidade, desde o início, exercida igualmente pelos dois, mesmo que apenas um deles seja o pai biológico ou legal. Em outros casos, pode ser uma parentalidade exercida conjuntamente pelo companheiro/a do pai/mãe legal de um filho nascido antes da relação de parceria como, por exemplo, na situação muito comentada na mídia, vivida por Eugênia, parceira da cantora Cássia Eller. O planejamento conjunto pode, também, incluir dois casais homossexuais, um masculino e o outro feminino, que decidem ter um filho através de inseminação artificial caseira (coleta de sêmen do pai e introdução do esperma na vagina da mãe, com o auxílio de uma seringa, sem a presença do médico) ou medicamente assistida (feita em clínica médica especializada). Nesse caso, a criança terá dois pais e duas mães, sendo dois deles pai e mãe biológicos. Tarnovski ${ }^{3}$ afirma que:

Durante os últimos anos, esse novo tipo de configuração familiar, as famílias formadas por gays e lésbicas, vem gradativamente conquistando as atenções da mídia nacional e internacional. Vários países, na sua maioria europeus, aprovaram ou colocaram em discussão leis específicas regulamentando as possibilidades de existência jurídica de tais famílias. $\mathrm{Na}$ maioria dos casos, o reconhecimento oficial da união homossexual marca uma etapa, a primeira e talvez mais importante, que, uma vez conquistada, abre

3 TARNOVSKI, L. - "'Pai é tudo igual?': significado da paternidade para homens que se autodefinem como homossexuais". In: PITISCELLI, A. GREGORI, M. F. e CARRARA S. (orgs.) Sexualidade e saberes: convenções fronteiras. RJ: Garamond, 2004. Pp. 385-414. 
espaço para a reivindicação de leis que permitam ao casal homossexual adotar ou ter acesso a novas tecnologias reprodutivas. A pressão por transformações gerou um intenso debate, político, acadêmico e popular, principalmente no que se refere à legitimidade e competência de gays e lésbicas para a criação de filhos, debate esse, não raro, permeado por julgamentos de valor e estereótipos negativos.

Diante dessa realidade cada vez mais visível, tornam-se necessárias a revisão e a reconsideração dos conceitos fundantes da família, a maternidade, a paternidade, filiação, pertinência, forçando-nos a rever valores e a buscar uma ética reguladora.

A família nuclear tradicional tornou-se uma referência normativa, um modelo a ser seguido e incentivado por médicos, juristas, psicólogos e outros profissionais representantes dos discursos disciplinares. Uziel ${ }^{4}$ afirma que a ideia de uma família natural, formada por pai, mãe e filhos, prossegue como uma referência marcante, alçada à condição de arranjo ideal (em detrimento dos demais) e não como uma possibilidade dentre outras. Ou seja, continua-se a utilizar o ideal heterossexista como ideal de família e a família homoparental tem que seguir, de alguma maneira, tais parâmetros, tanto para se sustentar enquanto família - grupo vincular afetivamente "indissolúvel" e "seguro" - como para conseguir reconhecimento social e jurídico. O que implica que nem se trata de uma família tão "estranha" ou "diferente", mas também não se trata de uma família como outra qualquer, isto é, modelar, ideal, a mais frequente, normatizada. Então, o que permanece das famílias normatizadas, heterossexistas, nas famílias homoparentais? O exercício das funções parentais? O desempenho dos papéis? Essas são algumas das questões que norteiam este trabalho.

No interior da abordagem psicanalítica, a parentalidade (função materna e paterna) é tida como lugar simbólico em que comparecem componentes sociocultural, político, simbólico e libidinal, conscientes e inconscientes, encarnado pelos representantes sociais - pais - e que tem a função de garantir a modalidade de inserção da criança e/ou filho no laço social. A relação de lugares e funções que se articulam, através da linguagem, da fala, afetos, gestos e atitudes, entre os pais e entre

\footnotetext{
${ }^{4}$ UZIEL, A. P. - Homossexualidade e Adoção. RJ: Garamond, 2007.
} 
estes e os filhos forma a estrutura simbólica da composição familiar, sendo de fundamental importância para a constituição subjetiva da criança.

Dessa forma, o presente trabalho tem como objetivo central o estudo da homoparentalidade, examinando o desempenho das funções materna e paterna, a partir de fragmentos de discursos de alguns sujeitos homossexuais que criam filhos, utilizando como referencial teórico a psicanálise de vertente de Freud e Lacan, bem como estudos socioantropológicos da sexualidade.

A importância deste trabalho se justifica pela atualidade do processo de novas configurações familiares, com famílias monoparentais e homoparentais implicadas com questões jurídicas, políticas e sociais que figuram na atualidade da cultura e da nossa sociedade.

Considerando-se ainda a complexidade e visibilidade do tema, além do fato de que as identidades sexuais alternativas ainda hoje é objeto de preconceitos; e de que estudos nessa área apenas se iniciam, acredita-se que a realização deste projeto de pesquisa se reveste de importância.

Além disso, espera-se que tal estudo possa trazer subsídios à compreensão de novas demandas que surgem ou que poderão surgir na clínica contemporânea, em relação às novas configurações familiares; e também que possa contribuir para a desconstrução (ou relativização) de discursos pré-concebidos a respeito da constituição da identidade sexual e de gênero, fortemente calcados em pré-conceitos de cunho moral, religioso ou até mesmo científico-naturalista (biológico), que desprezam ou minimizam o caráter subjetivo e as influências psíquicas e socioculturais que envolvem tal questão, visando a construção de uma sociedade mais justa, em que os sujeitoscidadãos possam ser melhor compreendidos e respeitados em seu direito à diferença.

Pretende-se dialogar e contrastar com as idéias e concepções de homossexualidade, família e parentalidade, a fim de se contextualizar os conceitos que embasam a análise dos fragmentos de discursos da pesquisa com sujeitos homossexuais com filhos. Como metodologia, foi a partir da pesquisa bibliográfica dos campos psicanalítico e sócio-antropológico, bem como do cotejamento conceitual entre ambos que se pensou os conceitos de paternidade e maternidade em sujeitos homossexuais que exercem ou desejam desempenhar essas funções parentais. 
Para dar início ao estudo da homoparentalidade, ou da articulação entre a homossexualidade e a parentalidade, faz-se necessário retomar algumas idéias a respeito da identidade sexual, mais especificamente da homossexualidade enquanto uma identidade psicossocial contemporânea.

O primeiro capítulo abordará a homossexualidade enquanto categoria aqui denominada psicossocial. Tratará de seu aspecto histórico a partir das vicissitudes das concepções e valores a ela atribuídos na cultura ocidental ao longo dos séculos, passando pela concepção médico-psicológica até a construção recente de uma categoria social e política. Em seguida, deter-se-á um pouco mais no aspecto sócioantropológico da identidade homossexual até chegar-se à articulação da(s) homossexualidade(s) e Psicanálise, abordando a posição dessa última a respeito da identidade e da sua concepção clínica, a fim de serem apontadas diferenças.

No segundo capítulo, tratar-se-á da constituição do sujeito segundo a abordagem psicanalítica. O processo edípico, conceito central dessa teoria, traz a marca da hierarquia de lugares simbólicos no interior do grupo familiar. Enquanto tal, traz a possibilidade de articulação entre a constituição do sujeito desejante, sua escolha de objeto e posição em relação à parentalidade como processo inconsciente.

O terceiro capítulo abordará justamente os aspectos e características da instituição familiar, tanto do ponto de vista histórico quanto sociocultural e psicanalítico.

O quarto capítulo trará, em seguida, a caracterização e os aspectos da família homoafetiva ou homoparental, seguindo a metodologia adotada neste trabalho de abordagem tanto sócio-antropológica quanto psicanalítica.

Adentrando os processos psíquicos presentes no grupo familiar, no quinto capítulo tratar-se-á dos conceitos psicanalíticos de função parental. Seguindo a abordagem de Freud e Lacan, será trazida a noção de função materna e função paterna bem como a diferença entre o conceito (psicanalítico) de função e o de papel (social) parental. Este capítulo é de fundamental importância para a delimitação dos operadores conceituais de análise, utilizados no capítulo seguinte.

No sexto capítulo, será trazida a análise dos fragmentos de discurso dos pares homossexuais com filhos, buscando demarcar a diferença entre papéis e funções, bem 
como analisar a manifestação e desempenho das funções parentais nesta outra forma de configuração familiar.

O trabalho será finalizado com reflexões advindas de todo o levantamento teórico e histórico realizado e da análise da referida pesquisa. 


\section{1: HOMOSSEXUALIDADE: UMA CATEGORIA PSICOSSOCIAL.}

Ao longo da história ocidental, a homossexualidade adquiriu diversas significações e entendimentos. Uma rápida revisão na História nos mostra a homossexualidade passando de um rito de iniciação para os jovens da Grécia antiga, uma prática sexual aceita no mundo latino, a um pecado, uma "abominação", na Idade Média até tornar-se um ato criminalizado durante a ldade Moderna até meados do século XIX, quando passa a ocupar um espaço entre as enfermidades, e, já na era contemporânea, especificamente, dentro da psicopatologia.

Hodiernamente, a homossexualidade saiu dos códigos de transtornos e doenças mentais e é considerada uma simples variante dentre a miríade de possibilidades da sexualidade humana. Vários percalços tiveram de ser superados até se chegar a essa concepção. Entretanto, ainda se enfrentam discursos opositores do campo moral e, principalmente, religioso, o que impede o avanço na conquista de direitos dos sujeitos que se reconhecem e se identificam como homossexuais.

$\mathrm{Na}$ Psicanálise, a homossexualidade já passou pelo rol das perversões, mobilizando pesquisas que se interessavam pela etiopatogenia ou psicogênese dessa variante da sexualidade humana. A partir da consolidação da ética desse campo de investigação e tratamento em direção à valorização cada vez maior da singularidade, a homossexualidade passa a fazer parte do modo de relação que o sujeito estabelece com os objetos e com o outro, o qual pode acentuar ou não o mal-estar do sujeito.

Tratar-se-á, neste capítulo, das diferentes posições que a homossexualidade ocupou na civilização ocidental até sua configuração no cenário atual como mote para o desenvolvimento da política de identidade(s) sexual(ais). Será abordada a articulação da identidade homossexual com a identidade de gênero numa perspectiva socioantropológica, além da visão atual da Psicanálise de vertente freudiana e lacaniana sobre a homossexualidade. 


\section{1: HISTÓRICO (BREVE) DA HOMOSSEXUALIDADE. DA MALDIÇÃO À CONSTITUIÇÃO DE UMA IDENTIDADE.}

Segundo Morici ${ }^{5}$, as distintas posições que ocupou ao longo da História sempre estiveram em relação com os graus e tolerância social que demonstraram ter as diferentes culturas em distintas épocas. Para a psicanalista, a tolerância social de uma cultura é dada pela relação entre a organização social particular de cada uma e a moral sexual hegemônica da época.

No Mundo Antigo greco-romano, a homossexualidade era tida como amor superior. Nos textos de filósofos gregos, tal como a "Ética a Nicômaco", de Aristóteles citado por Morici ${ }^{6}$, se pode ler o seguinte parágrafo: "esta disposição(homossexual) se dá naturalmente em certas pessoas... quando a natureza é responsável, não ocorreria a ninguém chamar de imorais a essas pessoas em maior grau que às mulheres, porque, no coito, estas são bem mais passivas do que ativas... e o fato de que um indivíduo com essa disposição a vença ou ceda a ela não é um problema moral propriamente dito".

Percebe-se que Aristóteles distancia a tendência homossexual de um problema moral, atrelando a tendência à "natureza" do ser humano. O que fica ressaltado no texto aristotélico, como particularidade, não é a escolha do sexo do objeto do desejo, e sim a referência aos desejos passivos nos varões. Os aspectos da conduta homossexual que Aristóteles considerava mais inusuais e menos "normais", como passividade nos varões, Ihe pareciam, inclusive, "naturais", posto que, no pensamento aristotélico, a "Natureza" era a criadora tanto do estatisticamente ordinário como do menos comum.

Alguns historiadores, tomando esse conceito da estética associada à juventude, deduziram, através da mitologia grega da época, que a pederastia (homem adulto em relação a um jovem) constituía praticamente um rito de iniciação para o jovem grego. No relato de Aristófanes, no texto clássico "O Banquete", de Platão, esses jovens efebos "erómanos" (jovens dos quais se obtinha prazer) do "eraste" (o amante, adulto

\footnotetext{
${ }^{5} \mathrm{MORICl}$, Silvia. "Homossexualidade: um lugar na História da intolerânca social, um lugar na clínica". In: GRAÑA, Roberto B. (org.) - Homossexualidade: formulações psicanalíticas atuais. Porto Alegre: Artes Médicas, 1998.

${ }^{6}$ ld., ibid.
} 
que outorgava prazer) estavam melhor dotados para a política. Era uma honra ser escolhido pelo "erasta".

Outros estudiosos consideram pouco provável que a prática da homossexualidade se tenha reduzido à pederastia. Supõem que esta teve uma prática extensiva entre adultos também.

Platão, que caracterizava o desejo sexual como quase exclusivamente homossexual, em sua obra "As Leis" afirma, de modo a surpreender os estudiosos desse filósofo, que "fazer uso do sexo com qualquer outra finalidade que não seja a reprodução é uma injúria ao nascimento, isto é, à natureza; é contranatura".

Platão, na verdade, não condena a homossexualidade em si, mas qualquer ato que fique aquém do que a própria natureza exige. O que há, segundo o filósofo, de antinatural na pederastia não é tanto o erro na escolha do sexo do parceiro como a artificiosidade no prazer: a pederastia, para Platão, não constitui um ato aberrante digno de fogueira, mas sim um ato abusivo, pelas "posturas" adotadas na relação. Ou seja, Platão não condenava a homossexualidade em si como antinatural (o amor pelo mesmo sexo, por exemplo), mas as atitudes por meio das quais se realizava. $O$ pederasta, na concepção grega via Platão, não era um monstro pertencente a uma raça de homens com pulsões incompreensíveis, era simplesmente um libertino movido pelo instinto universal do prazer, que o induzia a cometer um ato, o da sodomia, que, segundo acreditava, não existiria entre os animais.

Roma, apesar de compartilhar algumas atitudes socialmente tolerantes, apresentava algumas diferenças em relação aos sentimentos homófilos que imperavam entre os gregos.

Os romanos constituíam uma sociedade em que, com respeito à sexualidade, os censores mais severos não viam a sodomia mais do que como um ato libertino; a homofilia ativa não se ocultava, e os que se dedicavam aos jovens eram tão numerosos como os que gostavam das mulheres.

Para os romanos, numa relação sexual, o que importava era ser o que penetra (atividade) quanto ao mais, pouco importando o sexo do outro.

Se bem que a Grécia compartilhasse o mesmo princípio, havia uma diferença fundamental entre ambas as culturas com respeito à pederastia. Na Grécia, o amor 
pretensamente platônico dos adultos pelos efebos de estirpe livre estava amplamente difundido. Em troca, em Roma, o efebo de condição livre havia sido substituído pelo escravo, que fazia as vezes do favorito.

A censura recaía no caráter passivo da relação, e não na escolha do objeto, na medida em que a passividade implicava debilidade de caráter.

A homofilia aceita era, então, a relação do adulto livre com o adolescente escravo, na qual o gozo é só privativo do primeiro.

Fica clara, assim, na antiga Roma, a relação entre atividade-masculinidadepoder político e passividade-feminilidade-carência de poder.

Sociedades posteriores, longe de conservar a atitude aberta dos romanos para com a homossexualidade, dirigiram-se para uma intolerância cada vez maior quanto a este tipo de relação sexual.

O salto que se produziu, de uma sociedade extremamente tolerante à estreiteza de pensamento e intolerância social que caracterizou a Idade Média, foi abismal.

Sodoma deu seu nome às relações homossexuais em língua latina; ao longo da Idade Média. Tanto em latim como em qualquer língua vernácula, a palavra mais próxima a homossexual foi sodomita. No entanto, estudiosos do tema afirmam que a interpretação puramente homossexual do relato bíblico de Sodoma e Gomorra é relativamente recente. As interpretações que deram conteúdo sexual ao capítulo 19 do Gênesis, provavelmente, correspondem a um meio intelectual que se opôs vigorosamente ao despreocupado hedonismo do mundo helenístico, tendo seu auge nas interpretações do texto que se realizaram na Idade Média. A palavra sodomita, se bem aplicada à homossexualidade, em realidade se referia a atos sexuais não naturais de todo tipo.

Os escritos de Paulo refletem como, na moral cristã, existe uma profunda desconfiança para com os prazeres carnais, porque fazem do espírito um prisioneiro do corpo, impedindo-o de elevar-se até Deus.

A moralidade cristã não legitimava a união sexual, nem sequer no matrimônio, a não ser que encaminhasse a ter filhos ou a dar ao cônjuge o que the havia sido prometido mediante o contrato matrimonial. O casamento era considerado como um remédio que Deus deu ao homem par preservá-lo da impudicícia. 
Fica claro que, para o Cristianismo, a paixão erótica é um pecado com o qual o homossexual fica condenado por definição. Sua união implica todas aquelas práticas condenadas enquanto 'contranatura', já que não perseguem como fim a procriação.

O amor carnal, enquanto está associado ao prazer, é um rival do amor a Deus. $\mathrm{O}$ próprio do pecado mortal é distanciar o homem de Deus.

A partir do Cristianismo, então, existirá uma moral sexual relativa aos pecados contra o corpo, devido ao uso e abuso das inclinações sexuais, que se denominará concupiscência, isto é, inclinação a gozar dos bens terrestres, mais particularmente dos prazeres carnais. Haverá atos sexuais maus e proibidos, quase tão maus quanto o homicídio. É claro que a homossexualidade, até esse momento tão propagada pelo mundo helenístico, se converteu num ato abominável e proibido. Um lugar dentro do pecado.

Os teólogos medievais, tomando ao pé da letra o texto de São Paulo, associaram o pecado à união carnal ligada ao prazer, mesmo entre esposos.

Em geral, a Idade Média se caracterizou pela hierarquia organizativa, tanto da Igreja quanto a do Estado, que se tornou cada vez mais fixa e inflexível. Foram redigidos novos Códigos. Inventou-se a Inquisição para eliminar os fios soltos da Teologia e as divergências de opinião. Perseguiu-se as minorias, enquanto diferentes: judeus, homossexuais, prostitutas, hereges. Expulsou-se os judeus de territórios ocidentais. A homossexualidade foi perseguida também, na medida em que era considerada heresia.

A homossexualidade fica transferida de sua posição anterior, entre os pecados de excesso ou desenfreamento, a um grau novo e singular de pecado entre os tipos de conduta mais temidos pelas pessoas comuns e mais severamente reprimidos pela Igreja, como o canibalismo , a bestialidade ou o comer imundícies.

Vê-se, assim, como o alto grau de intolerância social que caracterizou a ldade Média coincidiu com uma posição teológica católica conservadora. Até 1300, não só havia desaparecido toda a literatura que aludisse à homossexualidade, mas também acontecia que um só ato homossexual bastasse para impedir a ordenação em qualquer nível da hierarquia eclesiástica, para tornar-se passível de perseguição dos Tribunais Eclesiásticos ou para merecer a pena de morte. 
A partir do século XIV até o século XIX, as diversas instituições sociais principalmente a Medicina e o Direito - incorporam a concepção medieval e cristã da homossexualidade, sendo esta perseguida e vista como pecado e crime passível de severas punições nas diversas sociedades nascentes do mundo ocidental, principalmente europeu. A Medicina, desde a época medieval até fins do século XVIII, converte a homossexualidade em uma doença.

O vocábulo "homossexualismo" é introduzido na linguagem por psicólogos alemães nos finais do século XIX.

A primeira aparição conhecida do termo homossexual na impressão foi encontrada em um panfleto de 1869, publicado anonimamente, pelo romancista alemão nascido na Áustria, Karl-Maria Kertbeny, argumentando contra uma lei anti-sodomia prussiana. Em 1879, Gustav Jager usou os termos de Kertbeny em seu livro "Descoberta da Alma" (1880). Em 1886, Richard von Krafft-Ebing usou os termos homossexual e heterossexual, em seu livro "Psychopathia Sexualis", provavelmente emprestando-os de Jager.

A partir daí, o "homossexualismo" se constituirá em tema de abordagem da psicopatologia. No entanto, previamente já tinha ocupado uma posição no âmbito das enfermidades.

Em geral, a conduta que se desaprovava ou que se considerava particularmente individual, costumava ser depreciada sob a qualificação geral de "doença". Como visto, no final da Idade Média, a heresia era considerada uma enfermidade, e não são poucos os "diferentes" que as sociedades assinalam como "doentes". Nenhum escritor antigo parece ter considerado patológica a atração homossexual, mas alguns tinham por "doentia" a conduta sexual passiva nos varões adultos.

O diagnóstico médico se apoiava em duas evidências: uma física, a dos estigmas do "vício"; outra moral, a de uma tendência quase congênita para o vício e que entranhava um perigo de contaminação para os demais. Pertenciam ao mundo marginal dos perversos.

É somente nos anos finais do século XIX que o problema da homossexualidade atraiu pela primeira vez os cientistas. 
Em 1897, Havelock Ellis empregou o termo 'homossexual' em Studies in Psychology of Sex, mas observava que a denominação se tratava de um "barbarismo híbrido" entre o radical grego homo (igual) e o latino sexualis (sexo), e se desligava, por isso, de toda responsabilidade por esse termo.

A partir do ano 1930, o termo 'homossexualidade' substitui toda a terminologia prévia que fazia alusão a ela (inversão, sexo intermediário, terceiro sexo, amor homogêneo, etc.). A maioria dos estudiosos supunha que as inclinações homossexuais eram congênitas e só se diferenciavam em pensar que eram um defeito (Krafft-Ebbing) ou parte do leque normal de variação humana ( $M$. Hirschfeld). O triunfo dos enfoques psicanalíticos dos fenômenos sexuais humanos teve como resultado o abandono geral desse enfoque a favor das explicações psicológicas.

Durante os anos 70 até nossos dias, produziu-se (e produz-se) uma abundante especulação sobre a probabilidade de uma viabilidade genética para os sentimentos homossexuais.

Após ser retirada dos manuais estatísticos e com o crescimento do movimento, a psicologia foi uma das primeiras disciplinas a estudar a orientação homossexual como um fenômeno discreto. As primeiras tentativas de classificar a homossexualidade como uma doença foram feitas pelo movimento sexológico europeu no final do século XIX. Em 1886 o notável sexólogo Richard von Krafft-Ebing listou a homossexualidade junto com 200 outros estudos de casos de práticas sexuais desviantes em sua obra definitiva, Psychopathia Sexualis. Krafft-Ebing propôs que a homossexualidade era causada por uma "inversão congênita" (no momento do nascimento) ou uma "inversão adquirida". Nas duas últimas décadas do século XIX, uma visão diferente começou a predominar nos círculos médicos e psiquiátricos, a julgar o comportamento como indicativo de um tipo de pessoa com uma definida e relativamente estável orientação sexual. No final do século XIX e início do século $X X$, os modelos patológicos da homossexualidade eram padrão.

Em 1952, quando a Associação Americana de Psiquiatria publicou o seu primeiro Manual Diagnóstico e Estatístico de Transtornos Mentais (DSM), a homossexualidade foi incluída como uma desordem. Quase imediatamente, no entanto, que a classificação começou a ser submetida ao escrutínio crítico em matéria de pesquisa financiado pelo 
Instituto Nacional de Saúde Mental. Esse estudo e a pesquisa subsequente falharam em conseguir apresentar qualquer base empírica ou científica para considerar a homossexualidade como um distúrbio ou anormalidade, ao invés de uma orientação sexual normal e saudável. Como resultado dessa pesquisa acumulada, os profissionais em medicina, saúde mental e em ciências comportamentais e sociais chegaram à conclusão de que era incorreto classificar a homossexualidade como uma desordem mental e que a classificação DSM refletia pressupostos não testados com base em normas sociais prevalecentes e impressões clínicas a partir de amostras representativas compostas por pacientes que procuram tratamento e por indivíduos cujo comportamento os conduziu ao sistema de justiça criminal.

Em reconhecimento da evidência científica, a Associação Americana de Psiquiatria retirou a homossexualidade do DSM em 1973, afirmando que "a homossexualidade em si não implica qualquer prejuízo no julgamento, estabilidade, confiabilidade ou capacidades gerais sociais e vocacionais." Depois de uma profunda revisão de dados científicos, a Associação Americana de Psicologia adotou a mesma posição em 1975, e exortou todos os profissionais de saúde mental "para assumir a liderança em eliminar o estigma de doença mental que há muito tem sido associado com orientações homossexuais."

Numa perspectiva médico-psicológica, utiliza-se o conceito de orientação sexual compreendida como o conjunto de fantasias, desejos, sentimentos e/ou conduta sexual de um indivíduo que se direcionam a alguém: de mesmo sexo (homossexualismo), do sexo oposto (heterossexualismo), de ambos os sexos (bissexualismo) ou a ninguém (abstinência sexual).

Nas últimas décadas do século $X X$, teve início, em escala mundial, um movimento crescente de desmedicalização e descriminalização do amor e da sexualidade entre iguais biológicos. Mas o alcance dos discursos dos poucos grupos religiosos que advogam a legitimidade do amor sexualizado entre homens e entre mulheres ainda é incipiente. 
Segundo Mello ${ }^{7}$

Se na atualidade é certo que em parte expressiva do mundo ocidental os homossexuais não são mais vistos como criminosos ou doentes, por outro lado, seu estatuto de seres humanos ainda não se encontra plenamente assegurado, talvez porque ainda seja recorrente a ideia de que gays e lésbicas subvertem as leis de Deus, da natureza e dos homens, no próprio cerne do que tornaria humano um ser humano: a capacidade de amar e ser amado.

Mello ${ }^{8}$ aponta, além do discurso médico-psiquiátrico da passagem do século XIX para o XX, particularmente no contexto europeu, outra modalidade discursiva que contribuiu de forma mais sistematizada e decisiva para a construção de uma identidade fundada na especificidade da orientação sexual: a ativista-militante da última metade do século $X X$, oriunda dos Estados Unidos e Europa. Embora médicos e homossexuais quase sempre sejam vistos como opositores natos nas lutas em torno das representações sociais acerca das homossexualidades, o que se observa é que seus discursos também atuaram como aliados no processo de construção de uma identidade homossexual.

Atribuir ao desejo e ao comportamento homossexual estatuto de doença significou, em fins do século XIX, um avanço político paradoxalmente incontestável, por proteger parcialmente os amantes do mesmo sexo da perseguição religiosa e policial. Aliando-se aos médicos e psicólogos, os homossexuais aceitaram sua condição supostamente patológica, como estratégia política, com vistas a assegurar a descriminalização de suas vivências afetivo-sexuais. Se os médicos contribuíram para a construção da identidade homossexual como materialização de uma doença que condicionava e determinava todas as demais características individuais dos doentes, escritores homossexuais - como André Gide e Marcel Proust, por exemplo - também contribuíram decisivamente para a afirmação de uma identidade estruturada numa

\footnotetext{
${ }^{7}$ MELLO, Luiz. Novas Famílias - conjugalidade homossexual no Brasil contemporâneo. RJ: Garamond, 2005. Pp. 191-214.

${ }^{8}$ Id., ibid.
} 
proclamada e valorizada diferença entre uma "essência homossexual" e uma "essência heterossexual" (COSTA $\left.{ }^{9}, 1992\right)$.

Foucault foi a voz mais contundente a afirmar - e a denunciar - a responsabilidade dos médicos e moralistas do século XIX na transformação do sodomita reincidente no homossexual membro de uma espécie. Nos termos propostos por Badinter" ${ }^{10}$, "a ênfase na ideia de minoria homossexual tornou difícil perceber a homossexualidade, explícita ou recalcada, como constitutiva da sexualidade de todo e qualquer ser humano".

Já a partir da década de 60, os homossexuais passam a ser os principais responsáveis pela reivindicação de uma nova identidade homossexual.

A homossexualidade - e não mais homossexualismo enquanto um diagnóstico médico-psiquiátrico - passa a ser reinventada pelos próprios homossexuais. Provavelmente, o principal fator responsável pela consolidação de uma nova identidade homossexual seja o alargamento crescente, ao longo do século $X X$, do campo semântico da própria homossexualidade, que passou a representar progressivamente tanto a atividade quanto a passividade nas relações afetivo-sexuais entre iguais biológicos. Em outras palavras: o homossexual não é mais compreendido apenas como o homem afeminado por sua passividade sexual ou a mulher hiperviril que se porta como homem em sua prática sexual e seu papel identitário social. Se, até os anos 7080 , os "comedores de viados" não eram socialmente representados nem se autorepresentavam como homossexuais, esse quadro começou a mudar radicalmente nos anos mais recentes, provavelmente como resultado da influência de uma série de fatores conjugados, entre os quais se destacam: a atuação do movimento homossexual organizado na defesa de uma política identitária, em que tanto a atividade quanto a passividade sexual são valorizadas como esferas constitutivas do campo semântico da homossexualidade; o advento da AIDS (Síndrome da Imunodeficiência Adquirida) e suas nefastas consequências, ao revelar a existência de muitas vivências homossexuais - passivas e ativas - camufladas sob o manto de uma

\footnotetext{
${ }^{9}$ COSTA, Jurandir Freire. (1992) apud MELLO, op. cit.

${ }^{10}$ BADINTER, Elisabeth. (1993) apud MELLO, op. cit.
} 
heterossexualidade doméstica; e a afirmação crescente de uma estereotipia homossexual centrada na virilidade e na força física extremadas e ostensivas, rompendo com o predomínio da fragilidade e da delicadeza como indicativos de desejos e práticas homossexuais.

Especialmente nos anos 60, nos Estados Unidos, com os acontecimentos desencadeados pelos conflitos de Stonewall ${ }^{11}$, a população homossexual estadunidense, inspirada nos exemplos de luta por direitos civis dos negros e das mulheres, passa a afirmar a especificidade e o orgulho de sua identidade, funcionando como um pólo irradiador da consolidação dessa identidade em escala mundial. Ao procurar a afirmação de sua igualdade formal na esfera pública, os homossexuais estadunidenses lutam, ao mesmo tempo, pelo reconhecimento de sua diferença, de sua especificidade, decorrente do fato de escolherem iguais biológicos como parceiros afetivos sexuais. O "sair do armário" ou o "assumir-se" - internalizar e publicizar uma identidade homossexual - transformam-se em bandeiras de luta e em palavras de ordem.

Em relação às mulheres homossexuais, as lésbicas, fenômeno semelhante, se bem que menos visível socialmente, pode ser observado, uma vez que, em muitos contextos sociais, a mulher feminina e passiva sexualmente no contato com outras mulheres não era questionada acerca de sua orientação sexual, enquanto a masculinidade e a "atividade" sexual de uma mulher pareciam ser elementos fundantes de uma homossexualidade desfeminilizante. Em associação com as transformações que vêm ocorrendo no universo das práticas afetivo-sexuais entre homens, tornou-se hegemônica - tal qual será utilizada neste trabalho - a representação que define como 'lésbica' qualquer mulher que mantenha vínculos amorosos e sexuais com outras mulheres.

11 A data de 28 de junho de 1969 é um marco internacional para o ativismo homossexual contemporâneo. Nesse dia, lésbicas, gays e travestis reagiram contra as frequentes investidas da polícia nova-iorquina ao bar 'Stonewall Inn'. A polícia, sob os mais diversos argumentos, invadia sistematicamente os lugares frequentados por homossexuais e realizava prisões e extorsões de clientes e funcionários. Uma explosão de raiva e frustração prolongou-se por dois dias e duas noites, numa dimensão nunca antes vista. Daí em diante, o "orgulho de ser gay e lésbica" tornou-se, além de uma palavra de ordem, o ponto de partida na luta contra a discriminação, o preconceito e a intolerância social contra homossexuais. 
A identidade homossexual/gay e homossexual/lésbica não é mais percebida, portanto, como intrinsecamente excludente das identidades de macho/homem e de fêmea/mulher, respectivamente, mas são assumidas como uma particularidade a mais, própria a cada um dos sexos. Essa nova compreensão foi reforçada também com a emergência, na Europa e nos estados Unidos dos anos 80, dos Gay Studies (Estudos Gays), os quais distinguem as categorias sexo, gênero e orientação sexual e tentam mostrar que ser gay ou lésbica não significa renunciar às identidades de homem e de mulher, respectivamente, nem também, em contrapartida, enquadrar-se incondicionalmente nos limites das representações sociais dominantes acerca do masculino e do feminino (BADINTER $\left.{ }^{12}, 1993\right)$.

Desde os fins do século XIX, quando da construção do homossexual como categoria médico-psicológica, até os dias de hoje, quando esta mesma categoria já assumiu uma dimensão claramente política, muito já se falou, se afirmou, se reavaliou, se proibiu, se puniu e se abriu mão no tocante às homossexualidades. Gays e lésbicas, por sua vez, cotidianamente têm redefinido suas identidades e se encontram - em diversos níveis de engajamento - empenhados na conquista do reconhecimento de sua cidadania e de seus atributos humanos.

O movimento homossexual pode ser considerado um dos atores sociais mais importantes destas três últimas décadas. No início dos anos 1980, observou-se, em vários países ocidentais desenvolvidos, uma mudança significativa no que se refere à luta contra a discriminação da homossexualidade. Dois fatos podem ser considerados os mais importantes: a saída da homossexualidade do código internacional das doenças e o fim da condenação da prática homossexual no código penal. A atuação política desse grupo influenciou na retirada do homossexualismo do DSM - III (Manual de Diagnóstico e Estatísticas das Doenças Mentais), desde o final do século XIX, com a criação do termo, e até então, considerado como doença ou transtorno de conduta sexual, as denominadas perversões sexuais.

Dessa forma, o avanço do movimento gay na esfera pública tornou visível uma prática afetivo-sexual que esteve condenada às mais severas repressões, pelo menos desde o início da era cristã.

\footnotetext{
${ }^{12}$ Id., ibid.
} 
Uma das referências fundantes do que pode ser considerado o movimento gay contemporâneo está na passagem de Foucault ${ }^{13}$, na História da Sexualidade, em que o autor sugere pensar que o surgimento da categoria de homossexualidade na era moderna foi utilizada para definir uma identidade. Nas palavras de Foucault:

É necessário não esquecer que a categoria psicológica, psiquiátrica e médica da homossexualidade constituiu-se no dia em que foi caracterizada - o famoso artigo de Westphal, em 1870, sobre "as sensações sexuais contrárias" podem servir de data natalícia - menos como um tipo de relações sexuais do que como uma certa qualidade da sensibilidade sexual, uma certa maneira de interverter, [intervir e/ou inverter] em si mesmo, o masculino e o feminino. A homossexualidade apareceu como uma das figuras da sexualidade quando foi transferida, da prática da sodomia, para uma espécie de androginia interior, um hermafroditismo da alma. O sodomita era um reincidente, agora o homossexual é uma espécie (FOUCAULT $\left.{ }^{14}, 1985\right)$.

A partir daí, o paradoxo da convivência entre a desconstrução teórica da categoria de homossexualidade com a afirmação militante da homossexualidade, de forma positiva, passou a fazer parte desse movimento que teve um efeito considerável na cultura atual.

Apesar dos avanços conquistados, no final dos anos 1980, o advento da epidemia da AIDS reanimou a velha onda de preconceitos contra homossexuais. Porém, se em um primeiro momento os homossexuais sofreram uma massacrante e desanimadora derrota, em seguida, a reação organizada do movimento gay configurou uma das mais importantes redes de prevenção e solidariedade em torno de vítimas da AIDS jamais vista, promovendo um novo fôlego de organização, a qual teve repercussão importante nas mais diversas esferas da vida social.

Como conseqüência, nos anos 1990, assiste-se ao crescimento da política de visibilidade da homossexualidade, principalmente nos Estados Unidos, tendo como um marco o Dia do Orgulho Gay. Junto a isso, em vários países ocidentais, vê-se surgir a luta pelo reconhecimento jurídico de casais homossexuais, que, embora assumindo diferentes formas de lei, de acordo com as características de cada cultura, coloca na

\footnotetext{
${ }^{13}$ FOUCAULT, Michel. - História da Sexualidade. vol. 1: a vontade de saber. Tradução: Maria Thereza da C. Albuquerque. RJ: Graal, 1985.

${ }^{14}$ Id., ibid.
} 
ordem do dia uma rediscussão sobre casamento, família e filiação. Os desafios desse movimento se faz pela passagem da invisibilidade para a visibilidade - o que significa o reconhecimento dessa prática afetivo-sexual - para, em seguida, passar a proclamar a desconstrução desse particularismo. Assim, esse movimento instaura, a um só tempo, a necessidade de repensar a política, como também subverte a idéia de identidade.

Até os dias atuais, é importante para estes sujeitos o reconhecimento e afirmação de uma identidade homossexual, para que se consiga e se continue reivindicando igualdade de direitos civis, tais como o reconhecimento jurídico da conjugalidade homossexual, com direito à herança, à comunhão e divisão de bens adquiridos, direito à adoção e criação de filhos, enfim, todos aqueles que são destinados aos homens e mulheres que constituem uma família e que são negados aos sujeitos homossexuais, pelo não-reconhecimento dessa relação.

Já no Brasil, o movimento homossexual surgiu no final dos anos 1970, definindo seu projeto de politização da questão da homossexualidade em contraste com as alternativas presentes no "gueto" e em algumas associações existentes no período anterior ao seu surgimento.

Academicamente, o estudo sociológico de Silva ${ }^{15}$ (1960) é um dos primeiros trabalhos acadêmicos a discorrer sobre o tema, trazendo um rico e ilustrativo quadro do estilo de vida e das condições sociais em que os homossexuais viviam no Brasil, e mais especificamente em São Paulo.

James Green ${ }^{16}$, historiador norte-americano e um dos personagens mais citados na bibliografia sobre a "primeira onda" do movimento homossexual brasileiro, em sua tese de doutorado, publicada no Brasil em 2000, propõe-se a "um exame das dinâmicas que levaram ao surgimento de um movimento politizado de gays e lésbicas no fim dos anos 70. Segundo Facchini ${ }^{17}$, o autor retrata e descreve detalhadamente, no decorrer do século, muito mais a diversidade das vivências individuais e grupais do homoerotismo masculino no eixo Rio - São Paulo, no decorrer do século XX, do que a

\footnotetext{
${ }^{15}$ SILVA, José Fábio Barbosa da. "Homossexualismo em São Paulo: estudo de um grupo minoritário" (1960). In: GREEN, J. e TRINDADE, R. (org.) - Homossexualismo em São Paulo e outros escritos. SP: Editora UNESP, 2005. Pp. 39-212.

${ }^{16}$ GREEN, James. Além do Carnaval: a homossexualidade masculina no Brasil do século XX. SP: Editora UNESP, 2000.

17 FACCHINI, Regina. Sopa de Letrinhas?: movimento homossexual e produção de identidades coletivas nos anos 90. RJ: Garamond, 2005. Pp.88.
} 
articulação de "complexas subculturas" que convergem na formação de uma nova identidade e de um movimento homossexual.

Facchini ${ }^{18}$ ressalta a importância de se notar "o quanto a ditadura militar", instalada no país a partir do golpe militar de 1964, "estimulou a formação de resistências em diversos setores sociais e como ela pode ter sido, inclusive, responsável pelo perfil fortemente antiautoritário que marcou a 'primeira onda' do movimento homossexual brasileiro dos anos 70". A fundação do primeiro grupo reconhecido na bibliografia como tendo uma proposta de politização da questão da homossexualidade, o Somos, de São Paulo, ocorreu em 1978. Os diversos grupos, associações e entidades, mais ou menos institucionalizadas, as quais compõem o Movimento Homossexual do Brasil, que foram surgindo ao longo dos anos 70 e 80 com certa queda nessa última década - e seu ressurgimento nos anos 90, compartilham da mesma crença na necessidade de visibilidade, no sentido de "assumir" a homossexualidade - e , por conseguinte, a identidade homossexual - como estratégia sociopolítica cujo objetivo é defender e garantir direitos relacionados à livre orientação sexual e reivindicar direitos civis, tais como o reconhecimento da união civil, a possibilidade de adoção e o reconhecimento da família homoafetiva, com igualdade de direitos em relação às famílias tradicionais.

Pode-se dizer que o surgimento da Parada do Orgulho Gay, em São Paulo posteriormente Parada do Orgulho LGBT (Lésbicas, Gays, Bissexuais e Transgêneros) -, em 1997, é o corolário das conquistas no campo sociocultural do ativismo político dos grupos homossexuais brasileiros, marcando a transmutação do sentido cultural da homossexualidade de pecado-crime-doença para elemento de constituição de identidade psicossocial contemporânea.

${ }^{18}$ Id., ibid. 


\section{2: A IDENTIDADE HOMOSSEXUAL SOB ENFOQUE SÓCIO-ANTROPOLÓGICO E SUA ARTICULAÇÃO COM A IDENTIDADE DE GÊNERO.}

Considerando a posição da psicologia e da psiquiatria que recentemente retiraram a homossexualidade da categoria psicopatológica, reconhecendo-a como uma variante normal da sexualidade humana ou um outro tipo de orientação sexual, é importante verificar a visão da homossexualidade na cultura atual a partir dos estudos sócio-antropológicos da sexualidade, que articulam a identidade homossexual com a categoria de gênero e identidade de gênero.

As definições tradicionais de identidade de gênero, ou seja, o autoreconhecimento do sujeito enquanto masculino ou feminino estão baseadas no 'heterossexismo', a norma simbólico-cultural que tem a relação entre os gêneros distintos, tidos como opostos, como seu ideal. A partir das discussões suscitadas pela teoria de gênero ${ }^{19}$ e as consequentes transformações nas relações entre gênero e sexualidade, com a disjunção entre essas categorias, é possível que 'gays' homossexuais masculinos - possam se definir também como homens masculinos, e 'lésbicas' - homossexuais feminina - como mulheres femininas, ainda que, conforme discurso 'heteronormativo' hegemônico, costuma-se falar de homossexual, seja masculino ou feminino, como alternativa, logicamente excludente, à identidade de homem ou mulher. Isso quer dizer que se algum sujeito se identifica como 'gay' ou como 'lésbica', conforme a lógica do senso-comum eles deixam de pertencer à categoria homem - masculino, por conseguinte - e mulher - feminina -, respectivamente. Tal ideia demonstra que, no interior da lógica da cultura heterossexista, a distinção entre gênero e sexualidade não se dá. Isso pode deduzir-se de falas, como a seguinte: "Aquele 'cara' não é gay, ele é homem" ou "quando as lésbicas e mulheres se reuniram para um mesmo fim...". Com estas ilustrações, é possível denotar que na lógica da cultura, a identidade de gênero masculina - e a

\footnotetext{
19 Teoria desenvolvida pela filósofa norte-americana Judith Butler, que demonstra a determinação cultural da construção do(s) gênero(s) a partir de uma matriz "heteronormativa", criando os gêneros por ela designados "inteligíveis". Cf. BUTLER, Judith. - Problemas de Gênero - Feminismo e subversão da identidade._Tradução: Renato Aguiar. Rio de Janeiro: Civilização Brasileira, 2003.
} 
feminina - passa, neste caso, pela negação e exclusão da homossexualidade, isto é, da identidade sexual baseada numa escolha de objeto homossexual.

Joan Scott ${ }^{20}$, antropóloga norte-americana e estudiosa do tema Gênero, demonstra que na lógica 'heterossexista' "a idéia de masculinidade repousa sobre a repressão necessária de aspectos femininos - do potencial bissexual do sujeito - e introduz o conflito na oposição do masculino e do feminino".

Assim, é possível observar-se que, de um lado, o feminino é a grande ameaça à heterossexualidade do homem; cada época define a categoria do risco, isto é, do que é considerado como feminino, mas o feminino é sempre a ameaça ao homem. Por outro, a masculinidade é interdita à mulher, pois a mulher no lugar do homem é o "mundo às avessas", a ordem corrompida, a natureza ultrajada. Portanto, homens homossexuais rebaixam seu sexo escolhendo estar abaixo de outros homens; e as mulheres lésbicas, por sua vez, usurpam um poder que não lhes pertence, e ao qual sequer podem usar, já que são desprovidas dos meios da consumação da masculinidade. Pois sendo mulher, e bela, espera-se que abandone "esse fingimento de escrever e meditar, e [comece] a pensar num homem, ainda que seja num mateiro. $E$, contanto que seja num homem, ninguém se opõe a que uma mulher pense" (WOLF ${ }^{21}, 1972$, grifo nosso).

$\mathrm{Na}$ lógica hegemônica, na qual gênero e sexualidade se confundem, homens gays são definidos quase inteiramente em termos de sua ausência de masculinidade. Assim, para os homens, a maior ansiedade com relação à homossexualidade está nesta identificação com o feminino, com o ser dominado por outro homem como se fora uma mulher. Invariavelmente, questiona-se a masculinidade daquele que é penetrado, oral ou analmente, por situar-se na esfera do feminino. O homem penetrado é homem desvalorizado, é homem sem poder. Na sodomia articulam-se igualmente as forças e jogos de prazer e poder da ideologia masculina.

Esta visão está baseada num sistema de identidade binário, que opõe bem e mal, boa e má sexualidade ou identidade sexual, a partir de uma "interpretação binária do mundo". Tal visão binária do mundo e das relações de gênero identifica o masculino e o feminino como termos opostos, ainda que complementares: eles podem conviver

\footnotetext{
${ }^{20}$ SCOTT, Joan. (1990) apud TORRÃO FILHO, Amílcar. - "Uma questão de gênero: onde o masculino e o feminino se cruzam". In Cadernos Pagu n.24. Campinas jan./jun. 2005.

${ }^{21}$ WOOLF, Virginia. Orlando. São Paulo, Abril Cultural, 1972 apud TORRÃO FILHO, Amílcar, op. cit.
} 
um com o outro, mas nunca um no outro. Os atributos considerados femininos são positivos se encontrados em mulheres, mas desqualificam os homens que os possuem, o mesmo se dando com a masculinidade em relação às mulheres. Neste caso, a natureza, isto é, a dimensão biológica, explicaria a essência de cada sexo, e perverter esta distribuição de atributos é perverter a própria natureza, sempre sábia em suas "decisões". Neste domínio do binário, as práticas e comportamentos sexuais e afetivos que não obedecem esta distinção dual serão tomadas, como desvio, perversão, "vão ser categorizadas para serem assim melhor excluídas da norma, do 'normal'" $\left(\right.$ SCOTT $^{22}$, 1990). Contra esta visão redutora, propõe a autora, a inclusão da ambigüidade que o termo queer - designação à vertente originalmente norte-americana de estudos acadêmicos no campo das ciências humanas sobre a diversidade sexual, principalmente sobre a homossexualidade - oferece, não apenas enquanto uma sexualidade alternativa, mas como um caminho para exprimir os diferentes aspectos de uma pessoa, um espaço também para a criação e a manutenção de uma polimorfia de um discurso que desafia e interroga a heterossexualidade.

Gayle Rubin ${ }^{23}$, importante antropóloga feminista norte-americana, afirma que as sociedades ocidentais modernas avaliam os atos sexuais de acordo com um sistema hierárquico de valor sexual. Os casais heterossexuais, ligados pelo casamento, estão sozinhos no topo da pirâmide erótica. Muito mais embaixo, nessa escala, estão os casais heterossexuais monogâmicos não casados, seguidos pela maioria dos outros heterossexuais. O sexo solitário oscila ambiguamente. O terrível estigma do século XIX sobre a masturbação continua em formas mais brandas e alteradas, como a idéia de que a masturbação é um substituto inferior para o encontro de parceiros. Casais estáveis, de lésbicas e de gays estão próximos da respeitabilidade, mas lésbicas de bares e homossexuais promíscuos estão pouco acima dos grupos que ficam na parte mais baixa da pirâmide. As castas sexuais mais desprezadas atualmente são os transexuais, os travestis, os fetichistas, os sadomasoquistas, os trabalhadores do sexo

\footnotetext{
${ }^{22}$ SCOTT, Joan. (1990), op. cit.

${ }^{23}$ RUBIN, G. - "Pensando sobre sexo -Notas para uma teoria radical da política da sexualidade". In: Abelove, Henry; BARALE, Michèle Aina e HALPERIN, David. The Lesbian and Gay Studies Reader. London/New York, Routledge, 1992. Gayle S.Rubin, Publicado pela primeira vez em VANCE, Carole S. (ed.) Pleasure and Danger: Exploring Female Sexuality, 1984.
} 
como prostitutas e modelos pornôs e, abaixo de todas os outros, aqueles cujo erotismo ultrapassa as fronteiras das gerações.

Os indivíduos cujo comportamento os situa na escala mais alta dessa hierarquia são recompensados com o reconhecimento de sua saúde mental, respeitabilidade, legitimidade, mobilidade social e física, apoio institucional e benefícios materiais. À medida que se vai descendo na escala dos comportamentos sexuais ou ocupações, os indivíduos que os praticam tendem a ser considerados doentes mentais e criminosos, têm sua mobilidade social e física cerceada, sofrem sanções econômicas e carecem de apoio institucional.

O estigma extremo e punitivo mantém alguns comportamentos sexuais num status bem baixo, e isso constitui uma sanção bastante efetiva contra aqueles que os adotam. A intensidade desse estigma tem raízes nas tradições religiosas do ocidente. A maioria de seus conteúdos contemporâneos, porém, deriva de opróbrio médico e psiquiátrico.

É a fortificação e consolidação do movimento homossexual, movimentos gays surgidos na Europa e nos EUA nos anos 1960 e 70 como forma de contestação à violência e perseguição sofridas pelos homossexuais, que vai propiciar a afirmação da identidade homossexual ou identidade gay, conforme autodenominação dos integrantes do próprio movimento.

Ainda dentro dos estudos sobre gênero e homossexualidade, Carrara e Simões ${ }^{24}$ afirmam que os inúmeros trabalhos realizados no Brasil nas últimas décadas são bastante díspares e dificilmente se pode abordá-los em conjunto. Em relação a tal produção, entretanto, é possível destacar os trabalhos do antropólogo Peter Fry, elaborados em grande parte ao longo da década de 1970 e publicados no começo da década seguinte. Particularmente o artigo "Da hierarquia à igualdade: A construção histórica da homossexualidade no Brasil"25, é um texto crucial para a configuração dessa área de estudos e referência quase obrigatória para os que nela se aventuram.

\footnotetext{
24 CARRARA, S. e SIMÕES, J. A. - "Sexualidade, cultura e política: a trajetória da identidade homossexual masculina na antropologia brasileira". In: Cadernos Pagu n.28. Dossiê: Sexualidades Disparatadas. Campinas, jan./jun.,2007.

Essa é a versão publicada de um texto que, conforme conta o autor, teve uma longa história: foi esboçado em 1974 e circulou restritamente no âmbito acadêmico, recebendo modificações e ampliações posteriores (Fry, 1982:87-115, ver p.112, nota 1). Cf. CARRARA, S. e SIMÕES, J. A., op. cit.
} 
$\mathrm{Na}$ reflexão de $\mathrm{Fry}^{26}$, é possível rastrear as bases de alguns dos problemas e conceituações centrais dos atuais estudos sobre sexualidade que, influenciados pelas vertentes pós-estruturalistas e pelos estudos queer, enfatizam a instabilidade/fluidez das identidades sexuais e a imbricação da sexualidade em relações de poder e hierarquias sociais dinâmicas e contextuais, tal como apontado por Rubin (1984).

Em seu artigo sobre a construção histórica da homossexualidade no Brasil, Fry ${ }^{27}$ descreve três sistemas taxonômicos que estariam diferentemente disseminados no país segundo as distintas classes sociais. No primeiro deles, a hierarquia de gênero, articulada a partir da oposição masculinidade/atividade sexual vs. feminilidade/passividade sexual, englobaria de forma sistemática todas as identidades sexuais. A categoria "homem", nesse caso, abarcaria todos os indivíduos do sexo masculino que supostamente mantivessem posição "ativa" em relações sexuais com mulheres ou homens, indiferentemente. Homens sexualmente "passivos", tratados como "bichas", "viados" etc., seriam percebidos como uma espécie de híbridos, nos quais atributos anatômicos masculinos se misturariam a características de gênero femininas (as comumente denominadas almas femininas em corpos masculinos). $O$ segundo modelo teria sido formulado, sobretudo, por médicos e psiquiatras e, nele, orientação sexual e gênero se desarticulam progressivamente. Nos seus termos, os homens que mantivessem relações sexuais com outros homens seriam considerados "homossexuais", não importando mais a posição "ativa" ou "passiva" que assumissem no coito. Neste caso, uma certa hierarquia manter-se-ia, mas com base na oposição normalidade/anormalidade-doença, sendo a homossexualidade um desvio doentio ou anômalo em relação à heterossexualidade, instituída em norma. Por fim, historicamente derivado do segundo modelo, o terceiro representaria uma espécie de reação a ele. Mantendo a disjunção entre orientação sexual e gênero e apoiando-se no dualismo hetero/homossexualidade, apenas alteraria o valor dos termos, contestando o estigma de anormalidade ou doença atribuído à homossexualidade. Assim, ter-se-ia um modelo hierárquico (o primeiro) e um modelo igualitário (o último) de construção das identidades e categorias sócio-sexuais, mediados pelo modelo médico-psicológico.

\footnotetext{
${ }^{26}$ FRY, Peter (1982) apud CARRARA, S. e SIMÕES, J. A. , op. cit.

${ }^{27}$ Id., ibid.
} 
A gênese do modelo igualitário é, assim, localizada no pensamento médico da passagem do século, presente tanto na Europa quanto no Brasil. Essa formulação estaria na base dos movimentos gays surgidos na Europa e nos EUA nos anos 1960 que, invertendo o valor atribuído à homossexualidade, fariam, segundo Fry, com que tal taxonomia adquirisse uma "legitimidade avassaladora". Como escreve ele, "De vez, o modelo médico é consagrado pela sua própria criação, a subcultura homossexual" (Fry, 1982:104).

Para Parker ${ }^{28}$, a noção de homossexualidade como uma categoria sexual distinta seria relativamente nova e as idéias relacionadas à identidade gay teriam emergido nas últimas décadas do século $X X$, no confronto da tradição brasileira com um "conjunto mais amplo de símbolos culturais e significados sexuais em um sistema mundial cada vez mais globalizado" (Id. ib.:53). Como se vê, processos que antes apareciam como desenvolvimentos paralelos e nos quais se poderiam encontrar algumas características comuns e outras singulares, surgem agora sob o modelo da "influência", da "importação" e "exportação" cultural. Isso fica explícito quando o autor diz ser sua intenção contribuir para preencher uma lacuna no campo dos estudos sobre a homossexualidade, pois, embora a invenção das categorias relacionadas à nova ênfase na orientação sexual no discurso médico e científico ocidental já tenha sido descrita em detalhe por inúmeros autores, "a exportação e importação dessas categorias fora do mundo anglo-europeu quase não receberam atenção nenhuma". (Id. ib.:66, grifos nossos)

Segundo Parker ${ }^{29}$, "além de um ritmo mais lento de emergência (explicado pela teoria do desenvolvimento dependente que teria 'atrasado' a estruturação do pink market nacional)", o que marca a comunidade gay brasileira seria, sobretudo, a permanência de distinções hierárquicas "tradicionais" (ativo/passivo), explicada pelo fato de o modelo econômico vigente manter e aprofundar as desigualdades sociais, reforçando, portanto, segundo o autor, o próprio caráter hierárquico da sociedade brasileira. Tal permanência do "velho", articulada às novas categorias "importadas", determinaria uma profusão de categorias e de tipos sexuais (Id. ib.:82) que, com a

\footnotetext{
${ }^{28}$ PARKER, Richard (2002) apud CARRARA, S. e SIMÕES, J. A., op. cit.

${ }^{29}$ Id., ibid.
} 
chamada globalização, estariam agora sendo "exportados" (sobretudo nas figuras de michês e travestis) para os países europeus e os EUA. É principalmente aqui, na glamurosa figura das travestis, que o autor localiza o impacto das elaborações culturais brasileiras sobre a cena gay internacional.

Deve-se ressaltar, ainda, que o movimento homossexual que emerge nos anos 1990 apresenta uma configuração polimorfa, abrangendo, além de grupos de orientação mais comunitarista, setores de partidos políticos, ONGs, associações estudantis e até grupos religiosos. Se, nesse contexto, as conexões intensificadas do movimento com as agências estatais e o mercado segmentado contribuem para reforçar a adesão a um sistema classificatório baseado na distinção de orientação sexual, vê-se também que a multiplicação de categorias destinadas a nomear o sujeito político do movimento, manifesta na atual sigla LGBT ("lésbicas, gays, bissexuais, travestis e transexuais"), é proposta em diálogo crítico com outras, como GLS ("gays, lésbicas e simpatizantes"), do mercado segmentado, que reelaborava a ambigüidade classificatória para ampliar o potencial de inclusão; ou HSH ("homens que fazem sexo com homens"), das políticas de saúde, que, talvez equivocadamente, buscavam contornar o problema da falta de coincidência entre comportamentos e identidades sexuais. Importa salientar, de todo modo, que a tensão entre as aspirações inclusivas e pluralistas, de um lado, e a adesão compulsória à lista de identidades reconhecidas como alvo da ação do movimento, de outro, não tem levado somente a conflitos amargos e autodestrutivos, mas também a iniciativas bem-sucedidas como as "Paradas do Orgulho GLBT", expressões de um espaço inclusivo de atuação política por meio de uma peculiar celebração das possibilidades de convivência com a diversidade sexual.

Em muitos lugares, principalmente na América Latina, a homossexualidade masculina é vista sob uma dupla moral. Ativos e passivos são encarados de maneira diferente. Enquanto o homem que é ativo na penetração por vezes não se considera como homossexual, ou seja, não coloca em questão sua preferência pelas mulheres e sua masculinidade, o passivo é estigmatizado como detrator de seu sexo. Analisando o 
início do século XX, mas aparentemente válido em nossos dias, James Green ${ }^{30}$ observa que havia

uma inconsistência no comportamento sexual de certos indivíduos em relação ao sexo "ativo" e "passivo" [que] com freqüência desafiava o paradigma "brasileiro" que definia e categorizava o comportamento homossexual.

Assim, alguns homens declaravam-se ativos ou passivos, mas na prática desempenhavam papéis variados. No entanto, isso não invalida a regra, pois os padrões não são contestados. Mesmo entre os homossexuais, a masculinidade e a virilidade são valorizados em detrimento dos maneirismos femininos, constituindo-se como um verdadeiro valor agregado na economia da conquista sexual.

\section{3: AS HOMOSSEXUALIDADES VISTAS PELA PSICANÁLISE. O PROBLEMA DO CONCEITO DE IDENTIDADE EM PSICANÁLISE.}

Foram abordadas as diferentes significações que a homossexualidade adquiriu ao longo da História, principalmente a sua condenação e perseguição a partir da era cristã, até o estatuto "científico" e político-cultural que apresenta na atualidade. Enquanto identidade sexual, é possível verificar-se que não há um só tipo ou estilo de homossexualidade, isto é, "os homossexuais" não formam conjunto: existem diversas formas de expressão da homossexualidade, a ponto de se poder referir às homossexualidades.

Atualmente, a Psicanálise, mais especificamente a de orientação lacaniana, adota ponto de vista similar quanto às homossexualidades, tomando, conforme cada caso, a identidade gay como um sintoma, no sentido psicanalítico do termo, ou como um significante de identificação (e alienação) do sujeito ao Outro ${ }^{31}$ (o coletivo gay, no

\footnotetext{
${ }^{30}$ GREEN, James (2000), apud CARRARA, S. e SIMÕES, J. A., op. cit.

31 Cf. MILLER, Jacques-Alain. "Des gays en analyse". In: LA CAUSE FREUDIENNE - Revue de Psychanalyse. Publication de L'École de La Cause Freudienne - Des Gays en Analyse? - N. 55, Octobre 2003. Paris: Huysmans, 2003. Pp. $82-90$.
} 
caso). No entanto, tal entendimento nem sempre prevaleceu. É importante ressaltar que do ponto de vista teórico-clínico, a homossexualidade nunca constituiu por si mesma uma entidade clínica. Todavia, de início, a homossexualidade na visão psicanalítica esteve atrelada ao campo das perversões em geral, seguindo o posicionamento da sexologia nascente de Krafft-Ebing.

Assim, num primeiro momento, Freud estudou a homossexualidade e as perversões em geral em "Três Ensaios sobre a teoria da sexualidade"32, de 1905, e em "Pulsões e suas vicissitudes"33, de 1915, fundamentadas sobre o principio das pulsões.

Nos "Três ensaios..." (1905), Freud adota a classificação de Krafft-Ebbing e assinala dois tipos de desvio: 1) desvio com respeito ao fim da ação. A esses chama perversão (sadismo, masoquismo, fetichismo, exibicionismo) e 2) desvios com respeito ao objeto: a esses chama inversão (homossexualidade, pedofilia, gerontofilia, zoofilia, auto-erotismo).

Mas já nesse artigo, Freud se distancia das concepções clássicas da perversão, entendida esta como desvio com respeito à norma, enquanto propõe a familiaridade do processo perverso sexual com o processo perverso normal. (Recordemos a definição da criança como um "perverso polimorfo", na medida em que está sujeita à ação das pulsões parciais que, por definição, estão coibidas em seu fim).

Ou seja, a perversão é um processo que se manifesta não só pelos desvios do fim da pulsão, mas também como uma inflação do processo sexual normal.

Por outro lado não escapará a Freud a relação entre intolerância social e homossexualidade. Ele aconselhou uma mãe, que o consulta por seu filho com tendências homossexuais, que este busque uma sociedade mais democrática, como a norte-americana, para nela viver. Esclarece a ela que a homossexualidade não é uma doença e que a psicanálise não altera tal inclinação.

$\mathrm{Na}$ análise de Freud de um caso de homossexualidade feminina, conhecido como a "jovem homossexual"34, conduzido sob a demanda de cura do pai da paciente, a homossexualidade é tratada como um sintoma a ser desvendado. Freud procura as

\footnotetext{
${ }^{32}$ FREUD, Sigmund. - "Três Ensaios para uma Teoria da Sexualidade" (1905). Edição Standard Brasileira das Obras Psicológicas Completas de Sigmund Freud. Vol. VII. RJ: Imago, s.d. 1 CDROM.

${ }_{33}$ Idem. - "Pulsões e suas vicissitudes" (1915). Vol. XIV, ibidem.

${ }^{34}$ Idem. - "A Psicogênese de um caso de homossexualismo numa mulher" (1920). Vol. XVIII, ibidem.
} 
origens dessa 'escolha' de objeto baseada, neste caso, nas vicissitudes do conflito edípico desta paciente. A homossexualidade é tomada, dessa forma, como um sintoma singular articulado à história de vida do sujeito. Com este caso, Freud busca também possíveis hipóteses e condições metapsicológicas para a posição subjetiva homossexual, sem, no entanto, patologizá-la, apesar do desejo de atender à demanda do pai de 'curar', de corrigir a posição homossexual para a heterossexual, tida como a normal. No entanto, Freud dá-se conta de que não é possível modificar a posição homossexual sem o desejo do sujeito e que, inclusive, numa resposta a uma carta de uma mãe de um homossexual que lhe escreveu, ele não aconselha esse intento, visto que a homossexualidade é uma variante da sexualidade humana, tal qual a heterossexualidade, não sendo nem mais nem menos vantajosa e, dessa maneira, considerando injusta a perseguição a que os homossexuais sofriam.

Há diversos outros casos freudianos em que a problemática da homossexualidade surge. No caso Schreber $^{35}$, análise de um psicótico, Freud interpreta o delírio paranóico como uma defesa do sujeito ante seus desejos homossexuais repudiados e projetados em outro homem sob a forma de um perseguidor. $\mathrm{Na}$ análise de Leonardo da $\mathrm{Vinci}^{36}$, Freud analisa a homossexualidade, relacionando-a ao modo de 'resolução' do complexo de Édipo dessa importante figura.

Freud chega à descoberta de que no inconsciente - ou seja, no discurso do Outro - a diferença anatômica dos sexos é transformada em significante e reduzida à problemática do ter fálico, enquanto as pulsões parciais em si ignoram a diferença sexual. Por conseguinte, é a orientação do desejo sexuado como tal que se torna passível de explicação. E logo se vê que, para Freud, nesse aspecto, homo e heterossexualidade estão em igualdade. Para ele, assim, um sujeito não pode amar sexualmente outro sujeito - seja de qual sexo for - sem haver renunciado ao objeto primordial, a mãe, e ao gozo referido a ela. Dito de outra forma, não sem uma castração do gozo.

\footnotetext{
${ }^{35}$ Idem. - "Notas psicanalíticas sobre um relato autobiográfico de um caso de paranóia (Dementia Paranoides)" (1911). Vol. XI, ibidem.

${ }_{36}$ Idem. - "Leonardo da Vinci e uma lembrança da sua infância" (1910). Vol. XI, ibidem.
} 
Após Freud, muitos foram os psicanalistas que estudaram o tema das perversões e da homossexualidade. Basicamente, a tendência de diferentes pesquisas psicanalíticas pós-freudianas sobre o tema tenderam a fazer uma diferenciação fina tanto na descrição clínica como na etiologia de distintos tipos de manifestações englobadas previamente no termo "homossexualidade".

Nesses estudos fica claro que as generalizações limitam a compreensão de uma manifestação que implica enormes diferenças condutuais e de estrutura. Há prostitutos homossexuais, homossexuais fetichistas, homossexuais afeminados, etc. toda generalização vai em detrimento da singularidade. O olhar ampliado do fenômeno nos permite descategorizar o mesmo. Seguiríamos Freud nisso, já que ele se negava a admitir que os homossexuais formassem um grupo de caracteres particulares que os distinguissem das demais pessoas.

Não é de se estranhar, então, que a linha de pesquisa psicanalítica tenha ampliado e ressignificado sua compreensão sobre a homossexualidade. Isso coincide com os processos sociais do fim de século, nos quais se assiste à debilitação das restrições que pesam sobre a homossexualidade.

A partir das três últimas décadas do milênio, já não são os médicos nem os clérigos, aqueles que fazem da homossexualidade uma categoria à parte, uma espécie, e sim os próprios homossexuais passam a reivindicar seu caráter de diferente. Seu corolário é o aparecimento e a cunhagem do novo vocábulo, auto-assignado: gay.

Esse termo deixa de lado o efeito mais aguçante do termo 'homossexual' ( o de estabelecer quem o é e quem não o é), ao convertê-lo numa categoria auto-designada. A partir de então, o termo gay aludirá às pessoas conscientes de sua inclinação erótica para com seu próprio sexo, enquanto uma característica distintiva, designativa de uma identidade.

Essa autonomização, auto-engendrada, os autoriza a si próprios; distanciando-os assim, finalmente, de categorias que são produto do posicionamento que a cultura criou para eles, ou seja, numa busca de saída de uma posição de objeto do discurso do Outro para uma posição ativa - no sentido político - , atuante e desejante. 
$\operatorname{Costa}^{37}$, eminente psicanalista brasileiro, faz uma importante ressalva, a partir da posição da homossexualidade enquanto identidade sexual, que delimita os campos epistemológicos para seu estudo. Afirma que

\begin{abstract}
identidade é um termo que não pertence ao vocabulário da psicanálise. Quando falamos de identidade referimo-nos imediatamente às ideias de ipseidade (o que faz com que um ser seja ele mesmo e não outro), continuidade e unidade. Ora, o sujeito da psicanálise é plural e descontínuo. A noção de identidade, no máximo, encontra equivalência conceitual no caso do ego. $A$ instância egóica, com sua compulsão à síntese, como afirmava Freud, busca manter-se homogênea e uniforme, não obstante a dinâmica pulsional e seu correlato, a permanente mobilidade intrapsíquica. Em vez de identidade, personalidade, pessoa ou indivíduo preferimos falar, metapsicologicamente, de sujeito ou de self como conjunto de processos identificatórios. Identificação, e não identidade, é o termo mais adequado à descrição dos processos mentais, vistos sob a lupa da psicanálise.
\end{abstract}

Vê-se assim que para o psicanalista, a homossexualidade, não só enquanto um comportamento sexual, mas como um complexo processo subjetivo de crenças, fantasias, afetos e atos simbólicos, faz parte do conjunto de processos identificatórios por que o sujeito passa.

Com o advento da política de minorias e a contígua criação da identidade 'homossexual', os próprios atores reivindicam o direito de falarem sobre si de maneira socialmente legítima. Para o autor, "trata-se, portanto, de saber como a psicanálise vem reagindo ao novo fenômeno, pois, historicamente, a maioria dos psicanalistas alinhouse às fileiras dos que definiam o 'homossexualismo' como doença, perversão ou retardamento do desenvolvimento psíquico" (COSTA $\left.{ }^{38}, 1998\right)$.

Costa avalia que a homossexualidade só pôde exprimir-se na vida pública a partir do momento em que certos valores morais e instituições sociais perderam grande parte de sua força normativa. Segundo o autor:

\footnotetext{
${ }^{37}$ COSTA, Jurandir Freire. (1998) - "A questão psicanalítica da identidade sexual". In: GRAÑA, Roberto B. (org.), op. cit.

${ }^{38}$ Id., ibid.
} 
Nas sociedades ou subculturas em que a família tradicional -com sua rígida divisão de papéis entre homem e mulher, marido e esposa, pais e filhos, adultos e crianças - continua sendo suporte da norma ideal da felicidade sentimental, dificilmente 0 'homossexualismo' poderia vir às ruas pleitear o direito concedido ao 'heterossexualismo'. Só numa sociedade invadida pelo individualismo paroxístico e pelo consumo massificado de bens com obsolescência programada, podemos aceitar a ideia de felicidade afetivo-sexual desvinculada das finalidades da família nuclear burguesa. Nesta família, sexo e sentimento eram peças indissociavelmente articuladas à constituição dos ideais do amorpaixão romântico e da parceria conjugal, ambos voltados para a reprodução biológica e social de pessoas e valores comprometidos com o universo da tradição patriarcal e conservadora. (...) Em resumo, é porque o sexo não tem mais a importância econômica, política e moral que teve nos séculos XVIII e XIX que a "identidade homossexual" pôde tornar-se uma identidade social exposta à opinião pública. $\left(\right.$ COSTA $\left.^{39}, 1998\right)$.

Assim, o psicanalista avalia que o surgimento da identidade homossexual é decorrência da derrocada dos valores culturais tradicionais atribuídos à sexualidade, do ponto de vista sociocultural e, do ponto de vista subjetivo, atrela a "escolha" homossexual aos processos identificatórios do sujeito. Nesse sentido, os sujeitos fazem de um traço subjetivo em comum e socialmente desvalorizado, elemento de constituição de um coletivo, que ganha força para reivindicar sua legitimidade. Porém, nem todos os sujeitos que reconhecem sua inclinação erótica pelos membros de mesmo sexo seguem essa tendência política e buscam com a psicanálise um sentido singular para sua sexualidade.

A partir de sua experiência clínica, Gérard Pommier ${ }^{40}$, psicanalista de orientação lacaniana, num texto publicado na "Revista Clínica Lacaniana" dedicado às homossexualidades, retoma a hipótese freudiana da posição homossexual enquanto vicissitude do processo edípico do sujeito. Neste texto, o psicanalista explana três posições diferentes para os "tipos" (clínicos) de homossexualidade identificada: a feminina ativa, a masculina passiva e a masculina ativa. Todo e qualquer sujeito, no

\footnotetext{
${ }^{39}$ Id., ibid.

40 POMMIER, Gérard. - "Existe uma distribuição lógica das homossexualidades?". In: Revista Internacional, № 4 - A Clínica Lacaniana - as homossexualidades. [Trad. Procópio Abreu; Editor: José Nazar]. RJ: Companhia de Freud, 2005.
} 
entanto, partiria de um lugar primordial de divisão - e necessidade de 'escolha' - entre uma posição identificatória de "objeto do gozo materno e uma identificação com o pai" que o protegeria disso. Tal lugar primordial é designado por Pommier como posição de 'bissexualidade' ou de 'transexualidade', porém, "no sentido lacaniano do termo, na divisão do sujeito, imediatamente tomado entre uma objetivação feminilizante pelo desejo do Outro e a entrada no falicismo, que é sua solução". Ou seja, Pommier articula o Édipo freudiano com o Édipo estrutural de Lacan tomado pela via do fenômeno. Como visto anteriormente, o pequeno sujeito, no interior de seu drama edípico encontra-se diante do dilema de "escolher" entre a sua devoração, permanecendo na posição de objeto do gozo do Outro materno, posição 'feminilizante' pois o sujeito permaneceria num lugar de total passividade e alienação ao desejo desse Outro, sem acesso ao seu desejo próprio - fálico, masculinizado, portanto. A alternativa é abdicar desse lugar para poder identificar-se com aquele que dá acesso ao falo, o pai em suas três dimensões imaginária, simbólica e real. Lacan mostrou que a fala era um primeiro instrumento de gozo: o sujeito barrado é sempre já sexual, preso entre a identificação com o falo (materno e imaginário) e o que o salva dessa identificação, isto é, uma identificação com o pai.

Pommier, seguindo Freud e Lacan, afirma que tanto os meninos quanto as meninas identificam-se primeiramente com o pai e entram no gozo fálico (da linguagem), fazendo da mãe, com a qual não se deveria sobretudo parecer, o primeiro objeto de amor deles. "Eles se falicizam paternamente a fim de extrair-se do nada". Esse nada seria a posição de não-desejante a que o sujeito fica submetido, quando não entra na ordem fálica, hipótese para casos de autismo e psicoses infantis.

Para Pommier, a brutalidade dessa posição primária 'bi' ou 'transexual' - e, talvez até mesmo assexual - explica a grande rigidez das escolhas de objetos sexuais, "tão forte que elas se assemelham a um destino orgânico contra o qual não se pode fazer nada". A escolha de objeto sexual raramente muda graças à análise e tampouco esse é, aliás, seu objetivo, o que já fora assinalado por Freud. A escolha do gênero sexual também é um dado precoce e constante, seja ele homogêneo ou não ao sexo anatômico. Segundo Pommier, na linha de Freud que denominava toda a libido como masculina, o gênero "é sempre primeiro "masculino", masculino querendo dizer: 
'atividade', gozo do órgão e escolha da mãe como objeto sexual. Esse termo 'masculino' não leva em conta o gênero menino ou menina e pede muitas precauções conceituais: essa masculinização é mais bem descrita pelo termo falicização, que dá conta, para os dois sexos, da escolha subjetiva de identificar-se com o pai”. Tal escolha corresponde à "entrada no gozo fálico, escapando ao gozo do Outro materno, e com investimento do atributo fálico clitoridiano ou peniano".

Clara Cruglak $^{41}$, outra psicanalista do campo freudiano e lacaniano, em um estudo sobre a identificação, mostra que Freud afirma que há uma identificação primordial do sujeito com o Pai. Tal hipótese estaria relacionada ao texto freudiano "Totem e Tabu"42, de 1913, em que se explica miticamente a origem das sociedades civilizadas. Nesse texto, o Pai da horda primeva, violento e egoísta, seria o detentor do gozo de todas as mulheres, excluindo deste seus filhos, tomados como rivais. A identificação com o pai resultaria, dessa forma, do papel violento e castrador que the é dado, e não de seu papel pacificador, de sua bondade. Segundo Pommier, “'identificação' significa querer tomar o lugar (do pai) em vez de estar no da mãe”. Como consequência disso, abre-se uma disputa ambivalente do sujeito com o pai - o momento da rivalidade edípica. Essa guerra prossegue às vezes por bom tempo, até a "resolução do conflito", quando o pai "deixou-se fazer" - termo de Pommier -, e que terá sido possível tomar seu lugar e, por conseguinte, passar ao amor da mãe. O pai "deixa fazer" na medida em que ele não é mais um filho, em todo caso não o de sua mulher, e não está, portanto, em rivalidade com o filho. Não é que este último travaria uma guerra ganha de antemão (se assim o fosse, ele a teria perdido), é que ele a leva para outros terrenos: aqueles do que é permitido e do que é proibido, o campo da enunciação da Lei, portanto. Do pai, a interdição e a punição são esperadas pelo filho: se for o caso, ele as faliciza sob o modelo da fantasia da "criança espancada". No resultado dessa guerra, esse pai, fonte indireta e involuntária - graças a seus golpes - de um gozo da mãe, será amado por ter sido primeiramente "detestado". "Se essa guerra não for travada, a detestação permanecerá. Esse ódio do pai tem por motivo a angústia de castração e a relação de rivalidade não resolvida que se situa na entrada do gozo fálico. Ele tem como consequência uma inibição de passagem à homossexualidade", ou

\footnotetext{
${ }^{41}$ CRUGLAK, Clara. - Clínica da Identificação. RJ: Companhia de Freud, 2001.

42 FREUD, Sigmund. - "Totem e tabu" (1913). Vol. XIII, loc. cit.
} 
seja, a possibilidade da posição heterossexual. A homossexualidade seria uma posição pela qual todos os sujeitos sexuados teriam tido passagem obrigatória na constituição de sua identidade sexual, mesmo que heterossexual, tendo sido inibida, em caso de consolidação desta última.

Nesse combate obscuro, a saída desejada pelo sujeito é a rejeição do feminino equivalente, nesse momento, à castração - e a afirmação do falicismo. Pommier ${ }^{43}$ afirma que "esse recalque da posição feminina é tal, na entrada no falicismo, que será em seguida um combate para as mulheres recuperarem essa feminilidade que, nesse sentido, sempre permanecerá problemática para elas; quanto aos homens, esse recalque do feminino, que tem consequências tão violentas para as mulheres, rege o habitual da relação deles com o pai e funda o patriarcado, que se apoia na homossexualidade endogâmica masculina", pois, no caso do menino, a fase de ambivalência (amor e ódio) que precede a identificação, contém o elemento homossexual - muitas vezes inconscientemente fantasiado, como mostrou Freud em "Uma criança é espancada" (1919) ${ }^{44 ، ~-~ d e ~ a m o r ~ a o ~ p a i, ~ q u e ~ t a m b e ́ m ~ e ́ ~ r e c a l c a d o . ~ " C o m ~}$ efeito", segue Pommier, "o habitual da heterossexualidade endogâmica masculina é comandado pelo recalque da homossexualidade endógama (o amor pelo pai) e o desejo de criança é regido pelo voto de fazer um filho para esse (dar-lhe seu nome) (...) o usual da heterossexualidade se apoia numa "homossexualidade" recalcada (amor pelo pai), o que esclarece as coerções da filiação patrilinear" (grifos meus).

Dessa forma, na 'saída heterossexual' masculina do drama edípico, o homem não só buscará no parceiro do outro sexo, o objeto de rivalidade paterna, a mãe; mas também, do ponto de vista narcísico e de identificação paterna, vai amar "numa mulher o que a ele próprio faltou ser para seu pai, movimento que procede o amor (pelo que ele foi) como o ódio (pelo que rejeitou de si mesmo)" (grifo meu). A heterossexualidade masculina se constrói, assim, sobre a base de um perigo de feminilização pelo pai - a ameaça de castração - e em reação contra essa angústia.

\footnotetext{
${ }^{43}$ POMMIER, Gérard. (2005), op. cit.

44 FREUD, S. - "Uma criança é espancada - uma contribuição ao estudo da origem das perversões sexuais" (1919). Vol. XVII, loc. cit.
} 
O esquematismo que acaba de ser retomado vai permitir, segundo Pommier, ordenar o campo das homossexualidades. Em todas as hipóteses, ele indica, portanto, que, se a entrada no falicismo significa uma identificação primeira com o pai, ela comanda primeiro uma atração "sexual" pela mãe, isto é, "a heterossexualidade" para os meninos e a "homossexualidade" para as meninas. Nota-se, a partir dessa primeira atração pela mãe, que o que se pode chamar de "homossexualidade feminina ativa" é a posição sexual mais fácil de ser entendida. Ela tem lugar no momento de eclosão da perversão polimorfa da infância. Pommier" ${ }^{45}$ aponta que "certas teóricas feministas afirmam que uma relação primeira com a mãe comanda a homossexualidade das mulheres, elas constatam esse estado de fato, embora omitam que essa ligação se estabelece a partir de uma identificação com o pai". Nessa operação, o pai seria deixado de lado. Essa ligação primeira com a mãe se coloca com violência para a menina, e ela, aliás, terá as maiores dificuldades em se desfazer dela, não representando os homens para elas, com frequência, senão "uma bóia de salvação relacionada a essa paixão devoradora".

Em comparação, o laço heterossexual dos homens com a mãe recobre (recalca) a feminilização potencial do sujeito e, por outro lado, a sorte dessa heterossexualidade vai depender da extensão da identificação com o pai, dada na família. Com efeito, o pai amedrontado pode opor-se a qualquer tentativa identificatória do filho, ou ainda, a mãe pode fazer o melhor possível para invalidar a figura paterna, que também pode, aliás, não ser muito valente. Se isso acontece com uma menina, esses ingredientes reforçarão sua "homossexualidade", ao passo que enfraquecerão "a heterossexualidade" masculina. Nesse caso, a relação identificatória de amor com o pai permanecerá prevalecente, desenhando as premissas de uma relação "homossexual" passiva com o pai, suscetível de passar à atividade por transitivismo, isto é, por identificação ao parceiro que ocuparia o lugar do pai.

O laço identificatório com o pai pode comportar, do lado masculino, três consequências, que resultam da posição do agente da castração em relação ao grande Outro. A primeira possibilidade já estudada é a passagem à heterossexualidade. Nesse caso, a ligação homossexual é recalcada, na medida em que o pai deseja a mãe, e

\footnotetext{
${ }^{45}$ Id., ibid.
} 
reciprocamente. Quer-se dizer com isso que a castração assume seu sentido para a criança na medida em que ela imagina primeiro que sua mãe foi castrada pelo pai. $E$ em seguida que o pai o é pela mãe, à medida de seu desejo por ela. São necessárias essas duas condições para que a heterossexualidade seja determinada imediatamente e a ligação homossexual recalcada a seu serviço.

Mas essa ligação homossexual não é forçosamente recalcada, ela pode também tomar a frente da cena, na hipótese em que não há recalque, mas negação (déni) da castração. Há aqui uma escolha entre a homossexualidade passiva ou ativa e as formas dessa negação da castração dependem das duas condições precedentemente enunciadas, das quais uma ou outra será privilegiada na configuração familiar (ou a mãe que castra o pai e a negação do pai que castra a mãe ou vice-versa). Poder-se-ia descrever essa configuração, em termos psicológicos, dizendo que "a homossexualidade passiva" corresponde à hipótese em que a mãe deseja o pai, enquanto que o contrário não é verdade. O homem encarna então uma figura viril esmagadora, mas distante. A criança aterrorizada por esse pai poderoso demais (que não está castrado por seu desejo pela mãe) vai, pois, colocar-se numa posição de sedução passiva em relação a ele. A sedução repetida poupa da angústia de castração dessa posição feminilizada que, como está destinada a preservar a virilidade, será sexualmente excitante. Essa possibilidade de resolução edípica condiz com uma saída identificatória, no que diz respeito à identidade de gênero, feminina, visto que há uma identificação com o feminino idealizado, que possa satisfazer o desejo do pai. Em virtude de uma separação entre o real e o imaginário pelo simbólico, não se trataria aqui de uma caso de desejo transexualista, mas, muito provavelmente, de um homossexual efeminado.

No que diz respeito à fixação de uma "homossexualidade ativa", ela procede da acentuação de uma figura oposta: $\underline{o}$ pai talvez deseje a mãe, mas a recíproca não é verdadeira. Esta última prefere a criança a ele. O pai está em seu lugar do ponto de vista simbólico (não se trata de psicose), mas é um simbólico que "come" todo o imaginário. O pai funciona como um lugar-tenente do pai morto, ao passo que do ponto de vista do sexo, está claro que seu papel é nulo. Nesse caso, o investimento da 
criança não é o (investimento) da mãe do psicótico (antes rejeitante), ele (o pai ) corresponde para essa mulher a uma valorização de seu papel de mãe: identificação com um ideal materno a título de resposta à questão do que é uma mulher. Essa resposta invalida o desejo sexual em geral, e para seu marido em particular. Por conseguinte, a perspectiva heterossexual será obturada por esse investimento e seu modo de desprendimento: o filho amará ativamente um rapaz semelhante ao que ele foi do ponto de vista do amor materno e tal como gostaria de ter sido desejado do ponto de vista de seu pai: amar os meninos como sua mãe amou a ele mesmo é uma maneira de identificar-se com o pai que ele gostaria de ter tido. Esta possibilidade de resolução é coerente com uma saída homossexual em termos de escolha objetal, mas uma identidade de gênero masculina, pela identificação ao masculino - pai - idealizado. "A homossexualidade masculina ativa", fazendo obra de justiça (já que busca paliar a falha de amor recebido ao dar amor), desdobra-se ao mesmo tempo numa negação (déni) da castração materna, que Ihe assegura sua erótica. Ela se inscreve, pois, no quadro da perversão polimorfa. Se é tão excitante amar um menino, é porque esse outro de si entregue ao Outro refere-se a uma potência paterna talvez violenta, mas salvadora. $O$ amor intenso da mãe só mais despertou uma identificação com um pai não simbolicamente (no caso de uma psicose), mas sexualmente ausente, mecanismo sem o qual não se compreenderia a excitação sexual sentida por homens.

Foram examinadas quatro posições que eclodem na infância. A urgência da identidade sexual e a da eleição de um objeto correspondente distribuem diferentes escolhas: a da "heterossexualidade", da "homossexualidade feminina ativa", "masculina passiva ou ativa". No tempo da infância, essas escolhas pertencem ao tronco comum da perversão polimorfa, conforme Freud ${ }^{46}$, e que se distingue da perversão propriamente dita. $O$ objetivo da primeira é transigir com a angústia de castração materna, graças à sexualidade pulsional e a uma identificação com o pai vivo. Já na perversão "adulta", que trata do pai morto, este último não é simbolizado pelas vias do sintoma ou do Nome-do-Pai como na neurose. É eternizado graças aos fetiches, e essa sobrevivência pereniza a sexualidade pulsional anterior, embora mude de sentido.

\footnotetext{
${ }^{46}$ FREUD, S. (1905) - op. cit.
} 
Seja como for, os três tipos "de homossexualidade" descritos até agora correspondem à perversão polimorfa da infância e funcionam conforme suas teorias sexuais, para as quais a questão da reprodução se regra pela via pulsional (ter uma criança oral ou anal). Segundo essas teorias, o inconsciente não conhece a diferença dos sexos e funciona na mesmice. Em consequência, esses tipos de homossexualidade desconhecem o desejo de ter uma criança, que é o feito da neurose, a título de tentativa de resolução da angústia de castração que é provocada pelo amor pelo outro sexo. Pommier ${ }^{47}$ conclui disso que, "se um homossexual deseja ter um filho, é na nostalgia da heterossexualidade (a maioria dos homossexuais teriam por muito tempo preferido não sê-lo). Até uma idade relativamente avançada, a maioria dos homossexuais não aceita sua homossexualidade, e a ideia de ter filhos como os heterossexuais é testemunha dessa recusa. Exprime-se assim uma nostalgia de não poder acertar a dívida que têm para com os próprios pais, dando-lhes filhos". Dessa forma, pode-se pensar no desejo de adoção ou de geração de filhos por técnicas de reprodução por parte de casais homossexuais - legítimos, vale frisar - como a expressão do desejo arcaico e nostálgico de saldar a dívida simbólica com seus pais, seus ascendentes, dando continuidade a sua linhagem patronímica.

Embora muitas vezes as escolhas sexuais (identificação e objeto) já pareçam bem decididas na infância, elas não definem o futuro. No fim da fase de latência, as escolhas podem se confirmar sob forma de uma fixação da perversão polimorfa da infância. Uma das homossexualidades pode afirmar-se, mas pode também, após um certo tempo de atividade durante a adolescência, virar heterossexualidade mais ou menos firmemente estabelecida. A atuação homossexual pode surgir também apenas a partir da adolescência, confirmando-se essa posição posteriormente. No entanto, a maioria das crianças ou dos adolescentes manifestou num momento ou noutro tendências homossexuais, que se confirmaram ou não posteriormente.

Finalizando, Pommier ${ }^{48}$ trata da posição homossexual feminina passiva. "O espírito de simetria gostaria que existisse também uma homossexualidade feminina

\footnotetext{
${ }^{47}$ POMMIER, Gérard. (2005), op. cit.

${ }^{48}$ Id., ibid.
} 
passiva: ora, essa categoria constitui problema do ponto de vista da lógica da sexuação, já que se vetorializa inteiramente a partir do agente da castração, isto é, o pai. Entende-se bem que possa existir para um homem uma "homossexualidade passiva" em relação ao pai, mas, se for o caso para uma mulher, isso se chama, é claro, heterossexualidade". Elucida, assim, que uma homossexualidade feminina passiva frequentemente se alterna com episódios de heterossexualidade ortodoxa. Tais sujeitos aproximam-se mais, portanto, do que Freud já considerou como a tendência à bissexualidade da histeria. "Tudo se passa como se uma decepção do amor heterossexual tivesse como consequência um episódio de homossexualidade, e isso durante algum tempo etc. Essa desilusão em relação a um homem sucede a uma decepção mais antiga em relação ao pai: o pai provoca uma excitação sexual e, como ele não satisfaz, entende-se o desapontamento. (...) A decepção leva a deixar-se amar como mulher por uma homossexual ativa". Pommier ${ }^{49}$ vai afirmar que essa homossexual será uma substituta 'restaurada' do pai falho. Aponta a frequência dessa homossexualidade feminina dita "adulta", distinguindo-a daquela das lésbicas militantes. "Tanto a maioria dos homossexuais está ligada à cultura gay, na qual se vê uma justificação e uma proteção, tanto a maior parte das mulheres homossexuais disso se desinteressa totalmente".

Comparando essa homossexualidade feminina adulta com a homossexualidade masculina, aponta que a primeira começaria quase sempre "após a puberdade, em continuidade a uma amizade romântica que desemboca em seguida numa atividade sexual", enquanto com os homossexuais, a atividade sexual surgiria em primeiro plano em detrimento do amor ou da amizade. Trata-se de "uma passagem iniciática" para se ter acesso à virilidade, a partir de uma identificação com "a impessoalidade paterna, passagem essa marcada pelos laços homossexuais com outros meninos".

\footnotetext{
${ }^{49}$ POMMIER, Gérard. (2005), op. cit.
} 


\section{2: A CONSTITUIÇÃO DO SUJEITO DESEJANTE: O COMPLEXO DE ÉDIPO EM FREUD E LACAN E A TEORIA DA SEXUAÇÃO.}

Neste capítulo, tratar-se-á da identidade sexual sob a ótica da teoria psicanalítica. Como se pode entender, no interior deste campo teórico e clínico, tais fenômenos da sexualidade humana? Essa investigação será iniciada pelo próprio conceito de sexualidade no interior do campo psicanalítico para, em seguida, verificarse, conforme a visão de Freud e Lacan, o processo de constituição do sujeito desejante e sexuado, a fim de se compreender os móbeis psíquicos das identidades sexuais e de gênero.

\section{1: SOBRE O CONCEITO DE SEXUALIDADE EM PSICANÁLISE.}

No início do século XX, mais precisamente em 1905, com os "Três Ensaios sobre a teoria da sexualidade", Freud traz a público sua descoberta da importância decisiva da sexualidade na vida do ser humano. Ele recorre à palavra alemã 'Trieb' (traduzida por 'Pulsão') para se referir à sexualidade humana, termo que evoca a ideia de 'força poderosa e irresistível que impele ${ }^{, 50}$. Assim, a sexualidade, para Freud, é mobilizada por uma força interna ao corpo, sendo a pulsão o representante psíquico dessas excitações provenientes do interior do corpo e que tem uma finalidade, que é a satisfação, sendo esta sempre parcial.

Tal concepção da sexualidade ampliou fortemente o espectro dos fenômenos humanos tomados como sexuais para além dos órgão genitais, abarcando o campo da relação do sujeito e o objeto da satisfação, bem como suas significações e seus efeitos em toda a subjetividade. Não se refere, portanto, diretamente às condutas ou práticas sexuais dos sujeitos, mas de sua identidade sexuada e do significado sexual inconsciente de muitas das condutas humanas, do ponto de vista da fantasia, do prazer e da satisfação inconscientes.

${ }^{50}$ FREUD, S. apud HANNS, L. - Dicionário Comentado do Alemão de Freud. RJ: Imago, 1996, pp.339. 


\section{2: ÉDIPO EM FREUD E LACAN.}

Uma das descobertas mais cruciais da clínica e da teoria psicanalítica que trata da questão da sexualidade e da constituição da identidade sexual é o complexo de Édipo. Na visão pioneira de Freud, trata-se de um estágio processual do desenvolvimento psicossexual, de importância capital e (sobre)determinante ${ }^{51}$ para os futuros posicionamentos sexuados e para as futuras escolhas objetais do sujeito. Apresentar-se-á, a seguir, a descrição desse processo na visão de Freud, bem como a sua reelaboração por Jacques Lacan, utilizando-se da visão estruturalista, o que não destituiu tal conceito de seu lugar central no arcabouço teórico psicanalítico. Pelo contrário, a visão lacaniana do Édipo, com a noção de metáfora paterna articulada ao aforismo do "inconsciente estruturado como linguagem" e, num momento posterior de seu ensino, "o inconsciente como discurso do Outro", amplia o campo de compreensão da influência da estruturação edípica em diversos fenômenos sociais e da cultura.

A seguir, demonstrar-se-á esse conceito na teoria freudiana e na lacaniana para, em seguida, compreender-se de que maneira ele aparece nos fenômenos socioculturais, ao que diz respeito às identidades sexuadas e à diferença sexual.

2.2.1: O Complexo de Édipo em Freud.

O termo 'complexo' foi originalmente utilizado pelo grupo suíço de Bleuler e Jung, com quem Freud havia começado a comunicar-se cientificamente por volta de 1906, vindo a designar, nesse contexto, um conjunto de idéias carregadas afetivamente e capaz de conduzir o curso associativo.

51 Sobredeterminação é o fato de uma formação do inconsciente - sintoma, sonho, etc. - remeter para uma pluralidade de fatores determinantes, podendo ser tomado em dois sentidos diferentes: a formação considerada seria resultante de diversas causas; num segundo sentido, a formação remete para elementos inconscientes múltiplos, que organizam-se em sequências significativas diferentes. (Cf. Laplanche e Pontalis, 1992, p.488) 
$\mathrm{Na}$ esteira dessa concepção de complexo enquanto uma matriz que governaria globalmente os processos psíquicos de um sujeito, Freud vai conceber inicialmente o complexo de Édipo como um conjunto de sentimentos, aptidões, emoções e ideias dadas pela natureza e com as quais, portanto, as crianças nascem, orientando sua relação frente a seus pais e determinando as posições do sujeito em relação à sexualidade, à identidade sexual, às escolhas de objeto, além de contribuir para a constituição dos mecanismos do funcionamento psíquico normal ou patológico. Como assinala Freud, trata-se, nesta primeira formulação de complexo de Édipo do "desejo amoroso pelo progenitor do sexo oposto e o desejo hostil em relação ao progenitor do mesmo sexo, desejo hostil este que culmina no da morte ${ }^{52 ", ~ i s t o ~ e ́, ~ n o ~ d e s e j o ~ d e ~ m a t a r ~}$ (eliminar) o genitor de mesmo sexo, tal como no mito grego de Édipo, para permanecer numa relação dual com o do sexo oposto.

Num segundo momento de sua obra, Freud irá teorizar o complexo de Édipo de forma mais completa, postulando uma ambivalência inicial da criança em relação aos pais (amor e ódio por ambos os pais), como também proporá a dissolução ${ }^{53}$ ou a saída do complexo através das identificações: do menino com o pai e da menina com a mãe. Neste momento, o complexo de Édipo deixa de figurar como uma tendência exclusivamente 'natural', tal qual posta na primeira formulação, passando a comparecer privilegiadamente regido pela relação com os outros, ou seja, pela criação e educação familiar, transmissão de valores e pela cultura, representada, no caso os pais, contexto no qual esse processo se realiza e se encaminha para seu fim $^{54}$.

Assim Freud ${ }^{55}$ descreve o que ocorre com o menino no complexo de Édipo:

52 Cf. FREUD, S. 'Um Tipo Especial de Escolha de Objeto Feita Pelos Homens (Contribuições À Psicologia Do Amor I)' (1910), Vol. XI, op.cit.

O termo 'dissolução' utilizado na versão brasileira da 'Edição 'Standard' das Obras Completas de Freud" é preferível aqui ao termo 'demolição', também utilizado em algumas traduções, visto que o primeiro termo denota a separação e dispersão das representações ligadas ao complexo, sem, no entanto, implicar em sua destruição ou inocuidade, tal como denotaria o termo demolição.

${ }^{54}$ Cf. FREUD, S. 'A Organização Genital Infantil' (1923); 'Algumas Conseqüências Psíquicas da Distinção Anatômica entre os Sexos' (1925) e 'A Dissolução do Complexo de Édipo' (1924), op. cit.

${ }^{55}$ FREUD, S. - Psicologia de Grupo e Análise do Ego (1921), Vol. XVIII, op. cit., Cap. 7 - 'A Identificação' 
Ao mesmo tempo em que ocorre essa identificação com o pai, ou pouco depois, o menino começa a desenvolver uma catexia de objeto verdadeira em relação à mãe, de acordo com o tipo [anaclítico ${ }^{56}$ ] de ligação. Apresenta então, portanto, dois laços psicologicamente distintos: uma catexia de objeto sexual e direta para com a mãe e uma identificação com o pai que o toma como modelo. Ambos subsistem lado a lado durante certo tempo, sem qualquer influência ou interferência mútua. Em conseqüência do avanço irresistível no sentido de uma unificação da vida mental, eles acabam por reunir-se e o complexo de Édipo normal origina-se de sua confluência. O menino nota que o pai se coloca em seu caminho, em relação à mãe. Sua identificação com ele assume então um colorido hostil e se equivale com o desejo de substituí-lo em relação à mãe, (...) que pode tornar-se expressão de ternura com tanta facilidade quanto um desejo do afastamento de alguém.

Neste ponto, pode-se perceber como o sentimento ambivalente - amor e ódio do menino surge a partir das relações de identificação e de rivalidade em relação ao pai. Prepara-se também, neste momento, a configuração do campo de dissolução do Édipo, principalmente a partir da inserção do seu elemento propulsor: a ameaça de castração e o conseqüente desenvolvimento do complexo de castração. Deve-se salientar que, ao se falar de complexo de castração, não se trata da perda empírica do pênis, mas do falo enquanto representação construída com base no grande valor que, para a criança, esta parte anatômica do corpo do homem costumeiramente vem significar.

Num primeiro momento, a criança desconhece a diferença anatômica entre os sexos, acreditando, assim, na existência universal do pênis, segundo a qual todos os seres, tanto animados quanto inanimados, possuiriam pênis. Essa crença é constatada por Freud em todas as crianças, tanto nos meninos quanto nas meninas ${ }^{57}$. Ambos ignorariam tanto a diferença entre os sexos, quanto a existência do órgão genital feminino, a vagina, atribuindo muitas vezes ao clitóris um valor equivalente ao que o menino confere ao seu pênis. Daí a saída proposta posteriormente por Lacan, dizendo

\footnotetext{
56 Anaclítico: tipo de relação de objeto que se baseia no apoio que uma figura representa em relação ao sujeito. Segurança, conforto, cuidados, são alguns significantes atribuídos a essas imagos, representadas inicilamente pelas figuras parentais (mãe e pai).

${ }^{57}$ Idem, 'As Teorias Sexuais Infantis' (1908); 'A Organização Genital Infantil' (1923), op. cit.
} 
não se tratar do órgão anatômico, mas de sua representação psíquica, enquanto elemento ausente ou presente nos seres, denominada falo.

Após o abalo na crença do menino na universalidade do pênis ${ }^{58}$, ao observar um ser próximo que não possui esse atributo, abre-se o caminho para a angústia dela própria ficar um dia similarmente despossuída. À época das ameaças verbais dos pais, que visam proibir e obrigar a criança a abandonar suas práticas auto-eróticas e suas fantasias incestuosas, incidem os efeitos dessas proibições sobre a fantasia do menino de um dia possuir seu objeto amado, a mãe. Essas admoestaç̃os verbais, em particular as proferidas pelo pai, progressivamente internalizadas pela criança, estarão na origem do supereu, aspecto que será retomado no capítulo posterior.

Quando o interesse da criança (do sexo masculino) se volta para os seus órgãos genitais, ela revela 0 fato manipulando-os freqüentemente, e então descobre que os adultos não aprovam esse comportamento. Mais ou menos diretamente, mais ou menos brutalmente, pronunciam uma ameaça de que essa parte dele, que tão altamente valoriza, Ihe será tirada ${ }^{59} .(\ldots)$

Mas, para Freud, é só no momento da visão privilegiada do genital feminino que o menino descobre a ausência do pênis, e quando a perda de seu próprio pênis tornase algo passível de ser representado. A ameaça de castração consegue fazer efeito só depois. É, então, sob o efeito da irrupção da angústia de castração que o menino aceita a lei simbólica da proibição do incesto e opta por salvar seu pênis, renunciando à mãe como parceira sexual. Com essa renúncia e o reconhecimento da lei paterna encerra-se a fase do amor edipiano e torna-se possível a afirmação da identidade masculina.

\footnotetext{
$58 \quad$ Neste ponto, é importante frisar que, durante todos os textos freudianos até "Algumas conseqüências psíquicas da distinção anatômica dos sexos" (1925), Freud apresenta o complexo de Édipo sempre centrado no menino - e tomando o processo na menina como equivalente invertido. A partir deste texto é que Freud proporá uma diferença no processo da menina em relação ao do menino.

${ }^{59}$ FREUD, S. - 'A Dissolução do Complexo de Édipo' (1924), Vol. XIX, op. cit.
} 
(...)sua aceitação da possibilidade de castração, seu reconhecimento de que as mulheres eram castradas, punha fim às duas maneiras possíveis de obter satisfação do complexo de Édipo, de vez que ambas acarretavam a perda de seu pênis - a masculina como uma punição resultante e a feminina como precondição. Se a satisfação do amor no campo do complexo de Édipo deve custar à criança o pênis, está fadado a surgir um conflito entre seu interesse narcísico nessa parte de seu corpo e a catexia libidinal de seus objetos parentais. Nesse conflito, triunfa normalmente a primeira dessas forças: o ego da criança volta as costas ao complexo de Édipo ${ }^{60}$.

Vê-se assim que o término do complexo de castração é também, para o menino, o término do complexo de Édipo. Como saldo desta dupla operação de renúncia aos impulsos hostis e incestuosos em relação aos pais e de internalização da autoridade paterna no eu da criança, forma-se o núcleo do supereu, que constituirá, na vida psíquica do adulto, a marca permanente da lei da proibição do incesto - a lei simbólica, nos termos de Lacan - e também a garantia da repetição, no curso da existência, dos três gestos fundamentais que marcam, para a criança, sua saída do complexo de Édipo: a renúncia ao gozo proibido, a preservação do desejo em relação a esse mesmo gozo considerado inacessível e a salvação do pênis da ameaça de castração ${ }^{61}$.

Num terceiro e último momento de sua teoria do Édipo, Freud irá postular uma diferença do processo edípico na menina em relação ao que se passa com o menino. Neste ponto, as modificações acrescentadas ao Édipo na menina estão relacionadas com o lugar que o complexo de castração ocupa nesse processo, o que faz com que o complexo de castração se converta no centro da experiência do Édipo tanto na menina, quanto no menino. Enquanto o complexo de castração no menino põe fim ao complexo de Édipo, sendo o motor de sua resolução, na menina, o complexo de castração inaugura a fase edípica propriamente dita: amor pelo pai e ódio e ressentimento pela mãe.

\footnotetext{
${ }^{60}$ Idem, ibid.

${ }^{61}$ Cf. NASIO, J. D. - Lições sobre os sete conceitos cruciais da psicanálise. RJ: Jorge Zahar, 1997, p. 130.
} 
A especificidade do Édipo na menina, e que requer modificações na sua teorização, dá-se primeiramente pelo fato de que a mãe é para ela seu primeiro objeto de amor, assim como para o menino. Faz-se necessário um abandono desse objeto a partir do complexo de castração para se dar, num outro momento, a versão edipiana simétrica e invertida: desejos incestuosos em relação ao pai e hostilidade em relação à mãe. Um primeiro tempo, semelhante ao que ocorre com o menino, se passa com a menina também: a crença na universalidade do pênis. Ignorando a diferença entre os sexos e a existência de seu próprio órgão sexual, isto é, a vagina, a menina acredita que seu clitóris é equivalente ao pênis, atribuindo-lhe o mesmo valor que o menino confere a seu órgão. No momento em que a menina descobre visualmente o genital masculino, a visão do pênis a obriga a admitir definitivamente que ela não possui o órgão peniano. Entretanto, como pode-se verificar na citação que se segue, tal falta não será, neste momento, atribuída a sua diferença sexual, mas a uma perda de algo que ela outrora possuiu.

Uma criança do sexo feminino, passa a desprezá-la [a mãe], a rejeitá-la por não the ter transmitido os atributos fálicos, ressurgindo, dessa maneira, o ódio primordial da primeira separação da mãe ${ }^{62}$ sob a forma de recriminações incessantes. Assim, a descoberta da castração da mãe leva a menina a separar-se dela pela segunda vez e, a partir daí, a escolher o pai como objeto de amor. Assim, inicia-se o complexo de Édipo da menina ${ }^{63}$.

Vê-se a seguir como Freud descreve de forma clara o que ocorre no complexo de Édipo feminino:

\footnotetext{
62 "O apego primordial - desde a origem da vida - da menina pela mãe interrompe-se com a perda do seio materno. Segundo Freud, uma vez que a mulher nunca se consola com tal separação, ela traz em si a marca do ressentimento de ter sido deixada na insatisfação. Esse ressentimento primitivo, esse ódio antigo, desaparece sob o efeito de um recalcamento inexorável, para depois reaparecer, por ocasião do complexo de castração." (NASIO, J. -D. - Lições sobre os sete conceitos cruciais da Psicanálise,. p.18)

${ }^{63}$ Idem, ibid.
} 
feminino, contudo, não entende sua falta de pênis como sendo um caráter sexual; explica-a presumindo que, em alguma época anterior, possuíra um órgão igualmente grande e depois perdera-o por castração ${ }^{64}$.

Diversamente do menino, para quem os efeitos da experiência visual são progressivos, para a menina os efeitos da visão do sexo masculino são imediatos.

Elas notam o pênis de um irmão ou companheiro de brinquedo, notavelmente visível e de grandes proporções, e imediatamente o identificam com o correspondente superior de seu próprio órgão pequeno e imperceptível [o clitóris]; dessa ocasião em diante caem vítimas da inveja do pênis ${ }^{65}$. (grifo nosso)

Percebe-se melhor a diferença essencial da incidência da castração na menina em relação ao menino. Ao passo que o menino vivencia a angústia da ameaça da castração, a menina a aceita como um fato consumado, vivenciando a inveja de possuir aquilo que viu e do qual sente que foi privada.

No momento em que a menina toma consciência de que outras mulheres, dentre elas sua própria mãe, também são desprovidas de um pênis

Estando assim excluído, na menina, o temor da castração, cai também um motivo poderoso para o estabelecimento de um superego e para a interrupção da organização genital infantil. Nela, muito mais que no menino, essas mudanças parecem ser resultado da criação e de intimidação oriunda do exterior, as quais a ameaçam com uma perda de amor. O complexo de Édipo da menina é muito mais simples que o do pequeno portador do pênis; em minha experiência, raramente ele vai além de assumir o lugar da mãe e adotar uma atitude feminina para com o pai. A renúncia ao pênis não é tolerada pela menina sem alguma tentativa de compensação. Ela desliza - ao longo da linha de uma equação simbólica, poder-se-ia dizer — do pênis para um bebê. Seu

\footnotetext{
${ }^{64}$ Idem, ibid.

${ }^{65}$ Idem, ibid.
} 
complexo de Édipo culmina em um desejo, mantido por muito tempo, de receber do pai um bebê como presente - dar-lhe um filho. Tem-se a impressão de que o complexo de Édipo é então gradativamente abandonado de vez que esse desejo jamais se realiza. Os dois desejos - possuir um pênis e um filho - permanecem fortemente catexizados no inconsciente e ajudam a preparar a criatura do sexo feminino para seu papel posterior ${ }^{66}$.

Neste trecho, Freud indica essa atitude da menina como a saída 'normal' do Édipo, além de diferenciar o motivo que leva à dissolução do Édipo feminino enquanto ameaça da perda do amor, ao passo que a ameaça de castração é o propulsor do fim do Édipo no menino. Pode-se constatar que, para Freud, o complexo de Édipo feminino é uma formação secundária, enquanto o do menino é uma formação primária. A feminilidade é, definitivamente, um constante devir, movido pela possibilidade de trocas, todas destinadas a encontrar para o pênis o melhor equivalente.

Mais adiante, verificar-se-á de que forma a questão da feminilidade e da Mulher será tratada por Lacan com a teoria da sexuação.

\subsection{2: O Édipo em Lacan.}

Em seu momento de ensino de retorno a Freud, Lacan reelabora a teoria do Édipo freudiano à luz do conceito de estrutura. Nessa época, a instituição analítica à qual Lacan pertencia - a Sociedade Francesa de Psicanálise (SFP) - ainda era filiada à Associação Psicanalítica Internacional (IPA). Tal reelaboração, todavia, não destituiu tal conceito de seu lugar central no arcabouço teórico psicanalítico. Explicitar-se-á, a seguir, o processo descrito por Lacan em três tempos lógicos, em seu seminário de 1958, sobre 'As formações do inconsciente'67.

\footnotetext{
${ }^{66}$ FREUD, S. - 'A Dissolução do Complexo de Édipo' (1924), Vol. XIX, op. cit.

${ }^{67}$ LACAN, J. - O Seminário, livro V - As formações do inconsciente. (1957-58). RJ: Jorge Zahar, 1999.
} 
Dessa forma, segundo a teoria, num primeiro momento a criança está, com efeito, cativa num certo modo de relação com a mãe, diante da qual o pai, como Pai real, é estranho. Esta relação é chamada, apropriadamente, de relação fusional, na medida mesma em que nenhuma instância exterior é suscetível de poder mediatizar seus móbeis do desejo. A indistinção fusional entre filho e mãe resulta, pois, essencialmente do fato de que o filho se constitui como o único objeto que pode satisfazer o desejo da mãe (e vice-versa). Esse primeiro tempo também é considerado de modo importante na teoria kleiniana, embora ressaltando outros elementos e aspectos dessa relação fusional.

Ficando fora do circuito da relação mãe-filho, o pai real não pode, então, pretender de maneira alguma assumir a função simbólica, de mediação e substituição, da qual virá a estar investido, num momento lógico posterior. $E$ isso acentuado pelo fato de que o filho, enquanto objeto suscetível de satisfazer o desejo da mãe, está, nesse momento, identificado ao seu falo, denominado, assim, de falo imaginário, pois esta identificação da criança ao falo é uma identificação estritamente imaginária. A mãe é, para a criança, toda fálica, pois seria, em sua fantasia, a imagem do objeto primordial de satisfação das necessidades e demandas do sujeito.

Num momento posterior, a criança se depara com a mãe enquanto Outro faltante, ou seja, se depara com a falta do objeto fálico na mãe. Como o falo - então como representante do objeto do desejo da mãe - não está lá onde se o deveria supor (ou seja, na mãe), a criança, neste limiar do Édipo, mantém uma relação com o falo aparentemente estranha à ideia de castração, já que ela própria é o objeto fálico. Semelhante objeto, em sua essência, é precisamente o objeto imaginário da castração, isto é, do corte de um objeto que deveria estar lá onde falta - este objeto é representado pelo pênis, na teoria freudiana.

Por esta razão, o Pai real, previamente estranho à relação mãe-filho, dificilmente poderia se manter durante muito tempo em tal exterioridade. Enquanto pai real, sua presença vai aparecer inevitavelmente como cada vez mais embaraçosa para o filho, a partir do momento em que o pai assume uma certa consistência significativa diante do desejo da mãe e daquilo que o filho está apto a apreender dele. 
A consistência do pai real quanto ao desejo da mãe vai, então, começar a questionar a economia do desejo do filho sob forma de intrusão. Essa interpretação suscita nele, assim, um requestionamento de sua identificação imaginária com o objeto de desejo da mãe. A criança entra, a partir daí, num momento de incerteza psíquica quanto à questão de seu desejo relativamente à certeza que tinha antes desse desejo diante do desejo da mãe. Só esta incerteza permite compreender como a criança começa a se confrontar com o registro da castração pela instância paterna.

Devido a esse confronto sub-reptício com a castração, esboça-se um novo móbil na dinâmica desejante da criança, que será daí em diante explicitamente vetorizada pela instância paterna. Cada vez mais, o pai real surge diante da criança como alguém que tem direito quanto ao desejo da mãe. Todavia esta figura não poderia, num primeiro momento, atualizar-se junto à criança a não ser no terreno da rivalidade fálica diante da mãe. Rivalidade fálica na qual a figura paterna será triplamente investida pela criança, sob os ornamentos de um pai privador, interditor e frustrador.

O pai real não precisa, de forma alguma, demonstrar deliberadamente essas impressões para ser tomado como tal pela criança. Apenas a incerteza da identificação fálica da criança a torna, a partir de então, mais sensível a esta presença paterna intrusiva. Além disso, ameaçada em seus investimentos libidinais arcaicos junto à mãe, a criança começa a pressentir insensivelmente alguma coisa que sempre esteve ali: a incidência do desejo da mãe em relação ao desejo do pai. Por mais desconfortável que seja , esta descoberta só pode mobilizar a criança para pressentir o pai real a uma luz cada vez mais imaginária. É, pois, essencialmente na qualidade de pai imaginário que a criança vai perceber daí por diante este intruso que detém o direito à mãe e que priva, interdita e frustra o sujeito: ou seja, as três formas de investimento que contribuem para mediatizar a relação fusional da criança com a mãe.

De um modo geral, o pai é pressentido como um objeto rival da criança junto ao desejo da mãe. Além disso, o pai aparece também como privador da própria mãe de seu objeto fálico simbolizado pela criança. Se essa rivalidade fálica, entretanto, incita a criança a viver imaginariamente a presença do pai sob o aspecto de um tirano totalitário, nem por isso deixa de atestar um deslocamento significativo do objeto fálico. Apresentando-se à criança como um hipotético objeto do desejo da mãe, o pai se 
mostra aos olhos daquela como um falo rival. Assim, em torno da interrogação da criança: ser ou não ser o falo da mãe, efetuou-se um deslizamento que é o do próprio falo. Desde que se suspeita que o pai é um falo rival, esboça-se a atribuição fálica paterna. Porém, se isto acontece, é sob o modelo de 'ser', já que o pai ainda não é suposto 'ter' o falo. É a partir do momento em que o pai se achar investido da atribuição fálica, que a função simbólica poderá ter um caráter operatório na estrutura psíquica do sujeito.

Além disso, tendo se deslocado o falo para o lugar da instância paterna - mesmo que o pai não seja ainda pressentido senão como sendo ele próprio o falo -, a criança é daí em diante conduzida, implicitamente, ao encontro com a Lei do pai. Em consequência, o desejo da criança pela mãe não mais pode evitar de chocar-se com a lei do desejo do Outro (então, o pai) através do desejo da mãe. De sorte que a criança deve fazer sua esta nova prescrição que irá regular a economia de seu desejo: o desejo de cada um é sempre submetido ao desejo do outro. Mas, tendo em vista a opressão narcísica implicada por esta prescrição, ela tem a oportunidade de entrever um novo deslocamento do objeto fálico.

Se o desejo da mãe é submetido de certa maneira à instância paterna, suposta privar, interditar e frustrar, disso resulta que a mãe também reconhece a lei do pai como aquela que mediatiza seu próprio desejo. Uma única conclusão se impõe, portanto, à criança: o reconhecimento que ela tem desta lei é apenas o daquela que regula o desejo que ela tem de um objeto que não é mais a criança, mas que o pai, em compensação, é suposto possuir. A criança acede , assim, ao estádio no qual: alguma coisa que destaca o sujeito de sua identificação o ata, ao mesmo tempo, à primeira aparição da lei sob a forma do fato de que, neste ponto, a mãe é dependente ; dependente de um objeto que não é mais, simplesmente, o objeto de seu desejo, mas um objeto que o outro tem ou não tem.

Com este novo deslocamento do objeto fálico vai se inaugurar o tempo decisivo do complexo de Édipo, no qual a instância paterna vai se desfazer de seus ouropéis imaginários para advir ao lugar do pai simbólico, isto é, um lugar no qual ele será investido como aquele que tem o falo. 
Na ordem do discurso, realiza-se uma construção metafórica pela substituição de um símbolo de linguagem por um outro símbolo de linguagem. Na medida em que a operação consiste em designar uma coisa pelo nome de outra coisa, a metáfora se desenvolve com base numa substituição significante no decorrer da qual um significante (o significante de origem - S1) é provisoriamente recalcado em benefício do surgimento de um outro (o significante substituto, denominado por Lacan de significante Nome-do-Pai). Na metáfora paterna ocorre uma operação dentro do mesmo princípio: um significante novo virá tomar o lugar do significante originário do desejo da mãe. Este último, recalcado em benefício do novo, vai se tornar daí em diante inconsciente. Só este recalque originário é suscetível de provar que a criança renunciou ao objeto inaugural de seu desejo. Em outras palavras, ela só pode renunciar a ele na medida em que aquilo que o significa tornou-se inconsciente para ela.

Nesta dialética edipiana, a criança é levada a abandonar a posição do 'ser' (o falo imaginário) para aceder à do 'ter'. Esta passagem só se poderá efetuar a partir do momento em que a criança tiver estabelecido uma associação significativa entre a ausência da mãe e a presença do pai. Mas, desde que se evoca uma associação significativa, supõe-se, necessariamente realizada, uma designação simbólica, já que uma coisa nunca faz sentido a não ser através de uma tal designação. Aquela de que se trata aqui, resulta de um processo metafórico.

Designando o pai como causa das ausências da mãe, a criança o nomeia como o que significa a ideia que ela tem daquilo que mobiliza o desejo da mãe. Assim, ela associa um significante novo o Nome-do-Pai (S2), ao significado falo (s1). A introdução deste novo significante S2 que substitui S1 (significante do desejo da mãe) faz então com que este último passe ao inconsciente. Ao final da substituição metafórica, o pai é doravante referido ao falo pela criança, enquanto objeto do desejo da mãe.

É apenas nessa medida que o Pai real foi investido como Pai simbólico, pela mediação do Pai imaginário. Entretanto, esta referência ao pai, daí por diante associada à ideia do desejo da mãe, é apenas um puro significante, o Nome-do-Pai.

A saída deste processo de simbolização é estruturante para a criança. Significando o pai como causa desejante das ausências da mãe, a criança continua, de fato, a designar o objeto fundamental do seu desejo. Mas ela o faz sem saber, dado 
que o significante originário do desejo da mãe foi recalcado. Em consequência, produzindo o significante Nome-do-Pai, a criança nomeia de forma igualmente metafórica o objeto fundamental de seu desejo. Daí resulta que o símbolo da linguagem tem por função principal perpetuar o objeto originário do desejo numa designação, sem que o sujeito daí por diante saiba alguma coisa sobre isso.

Fazendo-a advir como sujeito desejante, a renúncia da criança ao objeto fundamental de seu desejo, traduz explicitamente a expressão de sua castração. $O$ advento do Pai simbólico como Nome-do-Pai atesta, com efeito, o reconhecimento de um Pai castrador pela criança, não apenas em razão da atribuição fálica que lhe é conferida, mas ainda pelo próprio fato de que a mãe é suposta encontrar junto a ele o objeto desejado que ela não tem. O pai simbólico, pois, só surge para a criança como Pai castrador estritamente na medida em que a criança o investe igualmente como um Pai doador diante da mãe. Assim, a metáfora do Nome-do-Pai, que atualiza a castração, é necessariamente isomórfica à simbolização da Lei. Em consequência, a castração só poderia intervir no complexo de Édipo sob o aspecto de uma castração simbólica, à falta da qual permaneceria radicalmente ininteligível. De fato, tendo por objeto o falo, ela não pode traduzir outra coisa que não a perda simbólica de um objeto imaginário.

No que diz respeito à identificação sexuada do sujeito na saída do Édipo, podese dizer que duas saídas lógicas são, então, possibilitadas para o sujeito: uma identificação com aquele que - supostamente - tem o falo (o pai) ou uma identificação com aquele que não tem o falo - (a mãe, enquanto outro castrado) -, mas deseja tê-lo, portanto, uma identificação com sua posição desejante. Tal(is) identificação(ões) será(ão) a base da constituição da identidade sexual do sujeito. Vale lembrar que o falo, neste momento enquanto falo simbólico, não se trata do órgão real, do pênis, mas de um significante que o representa diante do desejo da mãe. E, dessa forma, diferentemente da visão freudiana, os móbeis da diferença entre os sexos e da(s) identificação (ões) do sujeito com um dos seus genitores não giram em torno da presença ou ausência do pênis, mas sim da ausência e presença do falo, primeiramente imaginário e, posteriormente, o significante símbolo da falta. 
É possível depreender do exposto acima, ainda, que não há saída lógica e obrigatória, no que diz respeito à identidade sexual do sujeito, enquanto masculino ou feminino, mas enquanto fálico ou castrado. Ainda que a junção entre esses termos (homem, masculino: fálico; mulher, feminino: não-fálico) seja comum e frequente na cultura, ela parece não ocorrer naturalmente, necessitando de uma outra operação simbólica de junção dos mesmos.

Como se vê, do ponto de vista da estruturação do sujeito, é a operação simbólica da Metáfora Paterna (instauração do Nome-do-Pai) que, ao mesmo tempo em que promove a constituição subjetiva, instaurará a sexuação, compreendida enquanto a forma como o sujeito se posiciona em relação ao falo: ter o falo, do lado homem; não tê-lo, mas ser o falo, no lado mulher.

Dessa forma, como consequência do Édipo estrutural, todos os sujeitos - a princípio - estariam situados do lado homem em relação à teoria da sexuação, por estarem totalmente submetidos à castração fálica, como será visto a seguir.

Segundo essa teoria, elaborada por Lacan ao longo dos anos 1970, até sua 'formulação' nas tábuas da sexuação, em 1973, no Seminário 20 "Mais, ainda”, os sujeito se dividem em relação ao falo de duas maneiras: os totalmente submetidos à função fálica seriam os sujeitos posicionados do lado HOMEM e os não-todos fálicos, seriam aqueles posicionados do lado MULHER.

\section{3: A TEORIA DA SEXUAÇÃO EM LACAN.}

Desde o início de seu ensino, por volta de 1950, Lacan demonstrou que a prática analítica implica uma determinada relação com a linguagem, e talvez seja essa uma das suas maiores contribuições naquele momento: a linguagem é indissociável do conceito de inconsciente.

A preocupação de Lacan é a de retomar a radicalidade freudiana de desconectar a sexualidade humana do âmbito puramente instintivo. 
Em nível conceitual, uma das principais dificuldades no debate interdisciplinar remete inicialmente à especificidade do termo sexualidade em psicanálise,_ele relaciona-se com algo que ultrapassa a esfera do organismo.

No Seminário XI, Lacan ${ }^{68}$ faz o seguinte comentário a respeito da relação entre psicanálise e sexualidade:

sobre a sexualidade, de fato, [a psicanálise] opera muito pouco. Nada nos ensina de novo quanto ao operatório sexual. Dela não sai nem um pouquinho de técnica erotológica. A psicanálise só toca a sexualidade no que, na forma de pulsão, ela se manifesta no desfile do significante, onde se constitui a dialética do sujeito no duplo tempo da alienação e separação.

Dessa forma, é possível verificar-se que a psicanálise não opera diretamente sobre a questão sexual e tampouco trata de um discurso sobre técnicas sexuais. A psicanálise trata da sexualidade, a partir de sua articulação com a linguagem, isto é, com a fala e o discurso. Em outras palavras, a sexualidade aparece na prática analítica sob a forma de discurso, a partir da relação do sujeito ao Outro, enquanto "tesouro dos significantes", utilizando a expressão de Lacan.

$\mathrm{Na}$ verdade, Lacan, no que diz respeito ao sexo, vai demonstrar que a feminilidade e a masculinidade são posições construídas e estruturadas a partir da combinatória de certos elementos. Assim, dirá ainda no Sem. XI:

No psiquismo não há nada pelo que o sujeito pudesse se situar como ser macho ou ser fêmea(...) o que se deve fazer como homem ou como mulher, o ser humano tem sempre que aprender, peça por peça do Outro ${ }^{69}$.

Neste momento, é possível depreender-se que é o Outro, tomado aqui como o Outro da cultura, do social, primeiramente encarnado pelas figuras parentais, e, em seguida, pelas figuras de autoridade com que o sujeito vai se relacionar (avós, outros

\footnotetext{
${ }^{68}$ Lacan, J. - O Seminário, livro 11: os quatro conceitos fundamentais da psicanálise. RJ: Zahar, 1989.

${ }^{69}$ Idem, ibid. Pp. 197.
} 
familiares ascendentes, professores e, posteriormente, outros grupos e a sociedade como um todo), que impõe ao sujeito as nomeações de suas normas e do conjunto significante de atributos, constituídos de modos variáveis histórica e culturalmente, do que é masculino e do que é feminino. Essa intervenção do Outro vai possibilitar ao sujeito constituir sua identidade sexual, a partir das identificações a alguns desses atributos de masculino ou feminino, sendo essas identificações, em outro momento, reconhecidas ou não pelo Outro.

Tal visão contrapõe-se radicalmente àquela biologizante e essencialista que afirma haver uma feminilidade "em si mesma", ou seja, inerente ao fato de se nascer do sexo feminino, com genitais femininos. Essa essência feminina estaria respaldada na anatomia, repercutindo na constituição psíquica. Assim, como homens e mulheres são anatômica e organicamente diferentes, supostamente essa diferença acabaria repercutindo naturalmente em seus respectivos "modos de funcionar" psiquicamente. Ainda segundo essa visão, a sociedade humana, dominada - por razões históricas pelos homens (sujeitos masculinos), acabaria atribuindo um juízo de valor a essa diferença natural, constituindo uma hierarquia, em que o masculino se sobrepõe ao feminino.

Por outro lado, como visto em capítulo anterior, uma outra tendência teórica opera com uma distinção entre sexo anatômico e gênero, este último sendo uma construção da cultura, ideia que, ao menos no que diz respeito à origem da constituição da identidade sexual, vai ao encontro d e alguns pressupostos e concepções da psicanálise lacaniana. A feminilidade e a masculinidade não teriam nada ou muito pouco de essencial, ou seja, as características atribuídas a um ou outro sexo seriam absolutamente flexíveis e determinadas por razões histórico-culturais.

É possível perceber que cada uma das vertentes acima discorridas essencialista/naturalista e a culturalista - sobre a assunção do sexo pelo sujeito busca dar conta do problema ora priorizando o aspecto natural/biológico, ora priorizando o aspecto cultural, sempre em detrimento do outro. Porém, algo sempre escapa a essas tentativas de articulação teórica: ambas desconsideram o aspecto psíquico e subjetivo da questão. 
Dessa forma, o conceito psicanalítico de sexuação parece vir a responder a essa hiância. A sexuação vai tratar da forma pela qual sujeitos homens e mulheres, na teoria psicanalítica de Lacan, relacionam-se com seu próprio sexo, bem como com as questões da castração e da diferença de sexos, considerando o aspecto subjetivo, singular e inconsciente dessa questão.

Como visto anteriormente, Freud atribuiu à sexualidade uma importância que exige modificação na sua definição. Se a sexualidade não se limita à genitalidade, se, principalmente, as pulsões sexuais dão origem, de forma indireta, ao nosso amor pela beleza ou aos nossos ideais e princípios morais, foi preciso ampliar de forma considerável a definição de sexualidade e introduzir à linguagem novos termos mais adequados. O termo 'sexuação', utilizado por Lacan, está entre esses. Para além do biológico, o termo designa a forma como são reconhecidos e diferenciados os dois sexos pelo inconsciente, perpassando, por sua vez, a estruturação da linguagem e da ordem simbólica. A teoria da sexuação é lida como a formalização lógica de uma dupla impossibilidade: a impossibilidade de reunir masculinidade e feminilidade de forma a que o conjunto faça uma totalidade (por isso o aforismo de Lacan "a relação sexual não existe") e a impossibilidade de que a própria feminilidade faça um todo (" $\underline{A}$ mulher - com maiúscula - não existe"). Desenvolve-se, em seguida, a proposta de Lacan acerca de uma idéia baseada no "não-todo", uma vez que a mulher estaria "não-toda" inscrita na função fálica. Na verdade, trata-se da atribuição de Lacan dos significantes 'HOMEM' e 'MULHER' a dois modos lógicos do sujeito posicionar-se em relação à função da castração: respectivamente, o todo fálico e o não-todo fálico.

Lacan desenvolverá as fórmulas da sexuação que pressupõem, pelo menos como preâmbulo, uma redefinição do falo ou da função fálica e uma indagação sobre sua dimensão universal. Se o falo/pênis, a partir de Freud, vale como significante do desejo, ao mesmo tempo é o significante da castração, enquanto esta nada mais é do que a lei que rege o desejo humano, que o mantém dentro de limites precisos. Portanto, Lacan chama de função fálica a função da castração.

A partir dessas definições, a questão decisiva irá se referir ao universal. $\mathrm{Na}$ perspectiva freudiana, o símbolo fálico, ao redor do qual se organiza a sexualidade humana, vale de direito para todos. Porém, o que significa exatamente esse "todos"? 
No caso, seria preciso retomar, com Lacan, a questão do que constitui um universal como tal. É sob a condição, aparentemente paradoxal, de que existe pelo menos um que não tenha se submetido à castração $(\exists \mathrm{x} \underline{\phi x})$, que faça a exceção à lei da castração, que se poderia propor a existência de um "todos" submetidos a ela ( $\forall \mathrm{x} \phi \mathrm{x})$. De fato, lembra Lacan, ela é própria a toda constituição de um universal. Para constituir uma classe, o zoólogo precisa determinar a possibilidade da falta de um traço que a diferencie; é somente a partir disso que poderá propor uma classe na qual esse traço não poderia faltar. Vê-se, a seguir, como Lacan trata da questão do posicionamento do sujeito no lado mulher, o lado 'não-todo':

Vocês tem a inscrição da parte mulher dos seres falantes. A todo ser falante, como se formula expressamente na teoria freudiana, é permitido, qualquer que ele seja, quer ele seja ou não provido dos atributos de masculinidade - atributos que restam determinar inscrever-se nesta parte. Se ele se inscreve nela, não permitirá nenhuma universalidade, será não-todo, no que tem a opção [consciente ou inconscientel de se colocar na $\phi x$ ou bem não estar nela ${ }^{70}$. (grifos nossos)

Como se pode verificar, fica clara a posição de Lacan de que não depende do sexo biológico do sujeito sua posição do lado homem ou mulher, em relação à sexuação, uma vez que esse posicionamento é escolhido - talvez inconscientemente -, porém não é algo inerente à anatomia ou, de modo algum, inato.

Além dessa articulação lógica, essas duas fórmulas ( $\exists x \underline{\phi x}$ e $\forall x \phi x)$ organizam a forma pela qual os sujeitos masculinos se referem à castração e, portanto, à função fálica: propondo a existência de um Pai que não seria submetido a ela (pode-se ilustrálo com o mito do pai da horda primitiva); a partir disso, estabelecem o estatuto daqueles que se atribuem um pai, mesmo morto. Pelo fato de que tiram partido de possuir as insígnias do Pai, de que aceitam sua lei, podem se reunir em lgrejas ou em exércitos, em sindicatos, em partidos, em grupos de todos os tipos. É sua maneira comum de fazer o universo, de fazer "todos".

\footnotetext{
${ }^{70}$ LACAN, J. - O Seminário, livro 20: Mais, ainda. RJ: Zahar, 1973. Pp....)
} 
Aliás, é notável que, para designar a espécie humana em sua totalidade (homens e mulheres), nossa língua fale em " O Homem". A mulher, diz Lacan, dessa forma, não existe. E não existe pois não é passível de ser tomada universalmente, formando um conjunto, como afirmado acima. Nesse caso, deve-se simplesmente entender que as mulheres não têm vocação para fazer universo. A posição feminina, segundo Lacan, pressupõe que cada sujeito seja tomado um a um, de modo a ser impossível formar um conjunto dos sujeitos femininos.

Escrever-se-á $\underline{\forall x} . \phi x$ (que logicamente lê-se "a não totalidade de $x$ tal que a função fálica $(\phi x)$ se aplica ao $x)$, que pode assim ser lido: do lado feminino, não-todas são submetidas à castração, elas não se reconhecem como todas submetidas a uma mesma lei. Isso então se ligaria à seguinte fórmula $\exists x . \phi x$, não há exceção à castração, dessa forma, designando que as mulheres não se referem, tão voluntariamente como os homens, a Um Pai, pelo que se sentem menos reconhecidas.

Essas fórmulas, que, apresentadas sucintamente, poderão parecer abstratas, de fato são operatórias em todo um setor das pesquisas psicanalíticas. Elas já serviram, entre outras coisas, para situar a relação específica do homem com os objetos parciais, desligados pela operação de castração [objetos a (objeto a)], assim como a relação das mulheres com o ponto enigmático que, no inconsciente, designaria um gozo Outro, diferente daquele que regula a castração - o denominado gozo fálico -, ponto identificável pela linguagem, mesmo não podendo ser descrito por ela.

É importante ressaltar-se que o gozo, na teoria lacaniana, não é equivalente apenas ao orgasmo ou ao prazer sexual, apesar de também se derivar dele. O conceito de gozo, em Lacan, surge, também, articulado à dialética do princípio do prazer e da realidade de Freud e deriva-se da concepção desse mesmo autor, em 'Além do princípio do prazer $^{71}$ (1920), de compulsão à repetição e a postulação da pulsão de morte, sendo assim, oposto à ideia de prazer.

Em 'O mal-estar na cultura" (1929), Freud se questiona: "o que é que os homens pedem à vida?" Sua resposta imediata é: "a felicidade". Encontra-se, nesse ponto, uma articulação da oposição entre gozo e prazer: "Esta aspiração tem duas

\footnotetext{
${ }^{71}$ FREUD, S. - "Além do Princípio do Prazer" (1920). Vol. XVIII, loc. cit.

72 Idem. - "O mal-estar na cultura" (1929). Vol. XXI, loc. cit.
} 
faces: por um lado evita a dor e, por outro, procura intensos gozos". Mas "a tarefa de evitar a dor relega a segundo plano a de obter o gozo". Aqui, parece-nos que os conceitos de gozo e de prazer estão bem próximos, ficando numa relação de prioridade de um sobre o outro.

Lacan salienta que Freud, em seguida, irá opor os pólos - evitar a dor e buscar intensos gozos - como inconciliáveis, remetendo o princípio do prazer a um princípio de constância. Freud fará um acoplamento entre o princípio do prazer e o princípio da realidade, estando os dois a serviço do princípio de não-desprazer. Entretanto, pode-se forçar a barreira desse princípio, e é nisso que consiste o gozo (Genuss, nos termos de Freud), já presente em textos como 'Além do Princípio do Prazer': "impressões freqüentemente dolorosas que são, no entanto, fonte de intenso gozo" (em alemão, hoher Genuss). Freud fala de uma irresistível tendência que se afirma sem levar em conta o princípio do prazer, e que apresenta freqüentemente um caráter demoníaco. Lacan, por sua vez, ainda salientará que é justamente esse princípio do prazer que barra o caminho ao gozo, que nos mantém afastados dele.

Nasio, estudioso da teoria lacaniana, ao tratar do conceito de gozo, aproxima-o à noção de energia psíquica. Segundo ele,

genericamente, o gozo e o prazer são duas formas distintas de expressão da energia psíquica. Porém, nem o prazer nem o gozo são estritamente definíveis em si. Só se pode situá-los por seu contexto: no tocante ao prazer, consideramos a consciência, a sensação e a baixa tensão; no tocante ao gozo, o fato de ele ser inconsciente, de coincidir com o aumento de tensão e de não ter, necessariamente uma sensação ${ }^{73}$.

Segundo este autor, no prazer, trata-se de uma diminuição da tensão psíquica, no sentido de repouso e da distensão.

\footnotetext{
${ }^{73}$ NASIO, J.-D. - Cinco lições sobre a teoria de J. Lacan. 1993 p.26.
} 
O prazer é, antes de mais nada, a sensação agradável percebida pelo 'eu' quando de uma baixa da tensão. O gozo, por sua vez, consiste numa manutenção ou um vivo aumento da tensão. Ele não é imediatamente sentido, mas se manifesta, indiretamente, quando das experiências máximas que o corpo e a psique, o sujeito inteiro, têm que atravessar. O gozo expressa a experiência de vivenciar uma tensão intolerável, mescla de embriaguez e estranheza. É o estado energético que vivemos em circunstâncias-limites, em situações de ruptura, no momento em que estamos em condições de transpor um limite, assumir um desafio, enfrentar uma crise excepcional, muitas vezes dolorosa ${ }^{74}$.

Para se compreender melhor esta distinção, o autor nos fornece a seguinte ilustração:

Por exemplo: uma criança que, cercada de coleguinhas, sobe num telhado íngreme e se deixa embriagar pelo risco de cair. Isso é da ordem do desafio. Ela goza não apenas com o desafio lançado a seus coleguinhas, mas com 0 fato de pôr a prova seus próprios limites. $O$ prazer é exatamente o contrário. Suponhamos essa mesma criança, agora relaxada, deixando-se embalar pelo movimento agradável de um balanço. Tudo nela está em repouso e descontração. Mas se, ao se balançar, ela é subitamente tomada pela vontade de conhecer o ponto limite que é capaz de atingir, mesmo com o risco de virar no vazio, o que ressurge é o gozo ${ }^{75}$.

Esquematicamente, portanto, segundo Nasio, o prazer equivale à tensão reduzida, enquanto o gozo equivale à tensão máxima. O gozo é o estado máximo em que o corpo é posto à prova, tal como na dor inconsciente, amiúde manifestada através dos atos impulsivos.

O gozo nunca é sentido imediatamente em seu auge, mas somente depois. $\mathrm{O}$ gozo faz pouco das palavras e do pensamento, para expressar-se apenas na ação. Uma das manifestações mais típicas do estado de gozo, tal como definido aqui - alta tensão psíquica -, é a passagem ao ato e, em geral, todas as ações, quer sejam perigosas ou não, mas que vão além de nós. Quando o gozo domina, as palavras

\footnotetext{
${ }^{74}$ Idem, Ibid., p.40

${ }^{75} \mathrm{Ibid}$, loc. cit.
} 
desaparecem e prima a ação. A irmã do gozo é a ação, enquanto do prazer é a imagem. O prazer é sempre dependente do vaivém das imagens que se refletem diante de mim. O prazer é uma sensação percebida e experimentada pelo 'eu'. Inversamente, o gozo faz-se ouvir por atos cegos, sejam eles ações produtivas, quando um pintor cria, fora de si, sua tela, ou ações destrutivas, como a do motorista que roçou a morte. São atos em que o sujeito é apenas corpo; o sujeito não fala e não pensa. ${ }^{76}$

Ainda na visão de $\mathrm{Nasio}^{77}$, a energia psíquica aproximar-se-ia daquilo que Lacan designa pelo termo gozo, com os três estados caracterizados do gozar: o gozo fálico, o mais-gozar e o gozo do Outro.

O gozo fálico corresponderia à energia dissipada durante a descarga parcial, tendo como efeito um alívio relativo, um alívio incompleto da tensão inconsciente. $O$ falo seria o limite que abre e fecha o acesso à descarga; Freud diria: o recalcamento. Lacan: o falo é a barreira do gozo.

O mais-gozar corresponderia ao gozo que, em contrapartida, permanece retido no interior do sistema psíquico e cuja saída é impedida pelo falo. O advérbio 'mais' indica que a parcela não descarregada é um excedente que aumenta constantemente a intensidade da tensão interna.

O gozo do Outro corresponderia à situação hipotética e ideal em que a tensão fosse totalmente descarregada, sem o entrave de nenhum limite. Esse é o gozo que o sujeito supõe no Outro, sendo o próprio Outro, igualmente, um ser suposto. É um estado ideal, um ponto de felicidade absoluta e impossível no horizonte, assumindo diferentes imagens, conforme o ângulo em que seja situado: a morte, por exemplo, para um obsessivo; para um histérico, pode se desenhar como um horizonte de loucura. No Édipo, assume a imagem da consumação do incesto.

Em relação à teoria da sexuação, Lacan, sempre referendado pela prática clínica, vai tratar de um outro gozo para além do gozo fálico - o dos sujeitos situados na posição masculina -, o gozo d'A Mulher (com A barrado). O gozo outro ou gozo feminino, gozo suplementar ou gozo do Outro (sexo) é assim denominado pois para

\footnotetext{
${ }^{76}$.lbid., p. 44

77 Ibid., p. 27
} 
aqueles caracterizados pela estrutura masculina, uma mulher é vista como Outro como radicalmente Outro, como o Outro do/como gozo - na medida em que ela corporifica ou é vista como um representante do gozo do Outro que Lacan chama de "indecente", pois ele não necessita de nenhuma relação com o falo e salienta a exiguidade do gozo fálico, que é a mera insignificância do prazer remanescente após as pulsões terem sido totalmente assujeitadas (no caso da estrutura masculina) ao simbólico. Essa sujeição das pulsões corresponde a uma determinada forma freudiana de sublimação, onde o real é sugado pelo simbólico.

O gozo do Outro envolve uma forma de sublimação através do amor que proporciona satisfação total das pulsões. O gozo do Outro é um gozo de amor, na medida em que "só o amor permite que o gozo digne-se a desejar" (Lacan, Seminário 10, 13/03/1963). Lacan o associa ao êxtase religioso e ao tipo de gozo material corporal -, que não está localizado nos órgãos genitais como o gozo fálico (o Outro gozo não é, Lacan afirma claramente, o assim chamado orgasmo vaginal definido como oposto ao do clitóris). De acordo de Lacan, o gozo do Outro é assexual (enquanto o gozo fálico é sexual), porém ele é do e no corpo, enquanto gozo experimentado no corpo do Outro. O gozo fálico envolve apenas o orgasmo como instrumento do significante. O gozo fálico, parcial, é aquele que suscita o protesto do "isso não é isso", e que segrega a miragem do que seria isso, o gozo absoluto, que poderia ser igualmente atribuído ao pai primitivo, porque não depararia com a castração. Mas o outro gozo distingue-se deste último.

Qual seria o efeito específico desse o "outro gozo”? 'Não é isso!' - aí está grito por onde se distingue o gozo obtido do gozo esperado. "A estrutura (...) ao marcar de que distância ele (o gozo) falta, aquele de que se trataria se fosse isso, não somente supõe aquele que seria isso (o gozo inacessível), mas sustenta com isso um outro" (LACAN, Sem. XX, p.152). (parênteses meus)

É esse outro que Lacan superpõe ao 'não-todo'. Vê-se, diz ele, "A potência lógica do não-todo ser habitada pelo recesso do gozo que a feminilidade furta ${ }^{78 \text { ". }}$ Soler $^{79}$, no entanto, afirma que "o fato de o gozo se manifestar de forma diferente no corpo dos

\footnotetext{
${ }^{78}$ LACAN, J. - "O aturdito", in Outros Escritos, 2006; apud SOLER, C. - O que Lacan dizia das Mulheres. RJ: Zahar, 2005, p. 231.

${ }^{79}$ SOLER, C. - O que Lacan dizia das Mulheres. RJ: Zahar, 2005, p. 231.
} 
dois sexos, o que é suficientemente atestado, não implica, por si só, que o da mulher seja outro. Para que sejamos autorizados a evocá-lo como outro, é preciso que ele seja determinado, diferentemente produzido pelo ser da significância. Lacan propõe que o S(A barrado) - leia-se: o significante da falta no Outro - simboliza a opacidade do gozo feminino e acrescenta ainda que, por causa disso, as mulheres têm mais relação com o $\mathrm{S}\left(\mathrm{A}\right.$ barrado) e, ainda por cima, que é com ele que elas gozam ${ }^{80 ", .}$

Soler continua seu argumento de que o ser da significância organiza o gozo, assim é ao que se refere à experiência analítica, mas não prova que ele o organize Todo. Não é impossível pensar, tendo em vista o animal, que o real do corpo vivo possa gozar sozinho, sem o significante. Isso também não prova que todas as diferenças de gozo Ihe são imputáveis. Formulando a hipótese de que algumas dessas diferenças provêm apenas do real do vivente sexual, compreender-se-ia que nada dele passa para o saber, e que, como observa Lacan, as mulheres não podem dizer nada sobre isso. "Conclusão: o fato de o gozo feminino ser diferente, de a mulher como sujeito ter mais relação com $S\left(A-\right.$ barrado), não basta para provar que é com ele que ela goza ${ }^{81 " . ~}$

Soler torna a ressaltar, como já afirmado acima, que Lacan propõe o 'outro gozo', encontrando apoio nos místicos.

Com efeito, há neles a ideia de um gozo outro, com o qual - sem garantia - pode-se tentar esclarecer o gozo feminino. Ao ler esses místicos, o que se indica é um gozo que seria produzido pela própria evocação do que está além do Verbo, de um Deus que seria não o Deus-Pai, aquele que diz não à função fálica, isto é, que encarna o paradoxo de produzir o Verbo sem ser sujeito dele, sem ficar preso nele, mas um Deus cuja identidade estaria além de qualquer diferenciação significante; um gozo em que presença e ausência se confundiriam, onde a opacidade do corpo que goza viria preencher a falha do sistema significante ${ }^{82}$.

\footnotetext{
80 Id., ibid., p. 231.

81 Id., ibid., p. 232.

82 Id., ibid.
} 
Vê-se que a concepção de gozo feminino por Lacan recebe alguns contrapontos por parte de alguns de seus comentadores. Enquanto Nasio, como visto acima, o associa a uma sublimação - ideia que também não está explícita no texto lacaniano Soler questiona a afirmação de que seria com este gozo, enquanto não tendo acesso a nenhum saber sobre ele, que a mulher gozaria. De qualquer maneira, Soler traz ideias baseadas na experiência clínica que atestam a pertinência da questão do gozo feminino presente em todos os sujeitos, tal como se vê a seguir:

É concebível, pois, que tal gozo possa ser mobilizado na análise. Mas, se o chamarmos de feminino, não seria preciso dizer que a análise é passível de feminilizar, e feminilizar não apenas as mulheres, porque a lógica do não-todo prende-se ao ser da significância? Isso não equivaleria, quanto aos homens, a fazer referência a alguma homossexualidade; equivaleria, antes, a evocar a relação com o que Lacan chama de outra face de Deus, a que é sustentada pelo gozo feminino: não a vertente do Nome-do-Pai, portanto, mas a da ausência do Nome ${ }^{83}$.

Fica evidente, assim, que o fato de o outro gozo ser denominado de feminino não o restringe aos sujeitos anatomicamente femininos; assim como o gozo fálico não é restrito aos homens, tanto no sentido biológico, quanto no estrito sentido psicanalítico (todo fálico). Conclui-se, dessa forma, que a anatomia não é determinante, para a psicanálise, da posição sexuada que o sujeitos irão assumir, podendo, assim, haver discrepâncias entre essas duas ordens. Porém, acredita-se haver uma primazia da posição sexuada sobre o fator anatômico, pelo fato da primeira incluir o sujeito numa ordem simbólica determinada pela linguagem e pela cultura, e, dessa forma, sobredeterminar as atitudes, ideias, sentimentos e comportamentos dos sujeitos, ao que se refere à diferença sexual.

83 Id., ibid. 


\title{
2.4: CONSIDERAÇÕES SOBRE O ÉDIPO, A TEORIA DA SEXUAÇÃO E A DIFERENÇA SEXUAL.
}

Soler ${ }^{84}$, a respeito do Édipo tal qual formulado por Lacan, afirma que

\begin{abstract}
Lacan formalizou um além do Édipo, precisamente, em referência à estrutura lógica e simbólica. Se o inconsciente decorre da linguagem, decorre também da lógica da linguagem. Daí a formulação: o inconsciente é pura lógica. Só o puramente lógico regula o que é totalmente diverso, ou seja, o gozo vivo dos corpos. Não é de admirar, portanto, que Lacan reformule a diferença entre os sexos, ao mesmo tempo, pela oposição de duas lógicas - a do todo-fálico nos homens e do não-todo fálico nas mulheres - e de dois tipos de gozo, um fálico e outro chamado de suplementar, ou outro gozo, gozo feminino.
\end{abstract}

Isso não significa que Lacan tenha refutado o Édipo freudiano. Ele o questionou, interrogou e criticou e, no fim, reduziu-o à sua lógica de conjunto do todo. Com isso, não o refutou propriamente, e o próprio Lacan considera que o mantém. Tudo do Édipo freudiano pode ser conservado, desde que nele se reconheça a lógica de que fala. É ela que produz o homem, todo homem, a partir da grande lei da castração que só lhe deixa, em matéria de gozo, o chamado gozo fálico, limitado e descontínuo como o próprio significante.

Portanto, ao logicizar o Édipo, Lacan também reduz seu alcance, e ai é que está a dificuldade: quanto ao que merece ser chamado de mulher, é de outra coisa que se trata. E isso é um além, porque essa outra coisa não está menos presa ao "ser da significação". O outro gozo, suplementar, que, longe de excluir a referência ao falo, soma-se a ela, não deixa de ser situável por uma outra lógica, esta não de conjunto: a do não-todo. Nesse ponto, portanto, Lacan diverge explicitamente de Freud, e de maneira precisa, no que concerne à castração conforme os sexos.

Freud não hesitou em retomar o dito atribuído a Napoleão: "A anatomia é o destino." Lacan objetou e propôs uma formulação que parece marcar o fim de qualquer ${ }^{84}$ Id., ibid., p. 17 
norma proveniente da natureza: "no que diz respeito a ser homem ou ser mulher, os sujeitos têm a escolha ${ }^{85}$ ".

Homens e mulheres, isso é real. Mas desse real, do real do corpo vivo sexuado, não podemos dizer nada. Nada podemos dizer porque existe "o muro" da linguagem, porque o real está fora do simbólico, mas lidamos com ele sob a forma muito precisa do gozo ${ }^{86}$

O real com que o corpo goza é inacessível; o único real acessível ao falasser, Lacan define pelo impossível. O mais real é aquilo que o discurso proíbe, no sentido forte, o que é impossível na lógica própria do discurso, aquilo que não se transgride. Trata-se de buscar "o que faz função do real no saber que a ele se acrescenta (ao real) $)^{87 ",}$.

Esse real que é apreendido nos limites do articulável, pelos impasses da formalização, esse real como impossível, só é possível de nos aproximarmos dele através da experiência da fala analítica, e nele está concernida a diferença entre os sexos, mas de que maneira?

Voltando à sexuação: esse sujeito dividido da fala é sexuado. O eu é uma função de síntese, mas de síntese imaginária, e implicado na questão do sexo. Lacan diz até que predomina nela, mas acrescenta: "Basta que o assunto 'eu' e o assunto falo... articulem-se na linguagem, para se tornarem assunto do sujeito, e não mais serem unicamente da alçada do imaginário."88

$\mathrm{Na}$ medida em que o sexo seria uma questão do sujeito, qual é seu dizer na análise, se o dizer é aquilo que sustenta a existência? O dizer de Freud, segundo Lacan, é o enunciado jamais formulado por Freud e que ele "restabelece": não existe relação sexual. Tal é a fórmula que se infere de todos os ditos do inconsciente descobertos por Freud.

\footnotetext{
${ }_{86}^{85}$ LACAN, J. - O Seminário, livro 20, Pp. 107

${ }_{86} \mathrm{O}$ real, como um dos três registros da experiência humana propostos por Lacan, além do simbólico (a linguagem) e o imaginário, tem como uma de suas formulações de Lacan: "aquilo que é impossível de simbolizar", portanto, que fica fora de qualquer possibilidade de se representar pela linguagem.

${ }^{87}$ SOLER, C., op.cit., 2005, pp. 222.

${ }^{88}$ LACAN, J. - "O aturdito", in Outros Escritos. RJ: Zahar, 2004, p. 457 apud SOLER, C., op. cit., p. 223.
} 
O "não existe relação sexual" implica que a relação é esperada. Para que a relação seja esperada, é preciso que haja dois, é preciso que a diferença esteja instalada no inconsciente.

A própria diferença é uma questão. A fala, nos homens e nas mulheres, é diferente, tanto pelo estilo, pelo tom, pelo conteúdo. Fala-se como homem ou como mulher, e se fala disso porque existem os significantes. No entanto, não se sabe o que é. Freud insistia muito no fato de que não havia representação de masculino-feminino no inconsciente. Vê-se funcionar, ora a recusa a ser homem ou mulher, ora mais frequentemente, a aspiração a ser verdadeiramente homem ou a ser uma mulher de verdade - além do que se imagina do homem e da mulher, nunca é senão o falo, em termos de tê-lo ou sê-lo. Assim, fala-se de homens e de mulheres, sem poder formar a seu respeito nenhum juízo de atribuição, que não esteja imbuído de pré-conceitos, de saberes pré-estabelecidos pelo Outro da cultura e de seus interesses ideológicos. Todas as ideologias sobre a questão da diferença - os homens são isto e as mulheres são aquilo - sempre supõe, por trás da atribuição, a referência a uma substância.

Sendo assim, como se impõe a diferença? A partir da pequena diferença anatômica. Porém, quando dizemos que homens e mulheres são diferentes, não apontamos uma diferença apenas na forma do corpo, implicamos que eles são diferentes como sujeitos. Logo, é por já ser um significante que o falo os diferencia. É por já estar presente o significante fálico que os dizemos diferentes, e, por os dizermos diferentes, eles passam a se relacionar diferentemente com a questão da diferença.

A distinção entre ser o falo (no caso das mulheres) ou ter o falo (para os homens), pela qual Lacan procurou abordar a divisão entre os sexos, é esclarecida pelo uso das funções proposicionais.

Quando se escreve (para todo $x$, fi de $x$ ), o argumento $x$, antes de ser relacionado com a função, é totalmente indeterminado, como Lacan deixa claro. O que permite determiná-lo, diferenciá-lo, portanto, é a modalidade inscrita no quantificador 'para-todo' (ou, ainda, qualquer que seja). Logo, quando se diz, como faz Lacan, que existe um universal do homem, podemos escrever: todos os homens, o homem está todo na função fálica; o que convém notar é que não é por ser homem que ele está na função fálica, mas, ao contrário, é pelo fato de um $\underline{x \text { indeterminado situar-se todo na }}$ 
função fálica que podemos chamá-lo de homem. Trata-se de uma imputação condicional. O significante homem é imputado aos $x$ que se alinham todos na função fálica, o que deixa intacta a questão de saber se existe sequer um deles.

Tal como quando escrevemos (para todo $x$, fi de $x$ ), não há um universal da mulher, a mulher não existe; as mulheres não estão todas na função fálica; não é por serem mulheres que elas são "não todas", mas, quando elas se alinham do lado do "não todo", podem ser chamadas de mulheres.

Não há essência do masculino e do feminino, por conseguinte, não há obrigação: a anatomia não é o destino. Tendo cada um a liberdade ${ }^{*}$ diz Lacan, de se alinhar de um lado ou de outro, existe escolha para ambos os sexos.

Porém, nessa matéria não pode tratar-se de uma liberdade por indiferença, porque o significante está ligado à anatomia. É um órgão do corpo que dá sua representação ao significante falo, e por isso se diz - o Outro diz - que um indivíduo é menino ou menina, antes de qualquer posição do sujeito.

Em todo caso, é certo que, como os significantes "homem" e "mulher" não deixam de se relacionar com a anatomia, o sujeito é representado a priori por um ou outros desses significantes, e não tem a opção de não se pautar por eles. Portanto, persiste a questão.

Esse "todo" e esse "não todo" representam duas possibilidades do sujeito falante, duas vertentes da estrutura. E, dessa forma, com a fórmula "para todo x, "fi' de x" ( $\forall \mathrm{x}$. $\Phi x)$, isso quer dizer que todo sujeito como tal , como ser falante, se inscreve na função fálica, e é justamente por isso, por outro lado, que se pode dizer que se as mulheres estão não-todas na função fálica, nem por isso deixam de estar nela.

Para definir esse "fi de x" ( $\Phi x)$ e o gozo fálico que ele sustenta dizemos: a função fálica é a função da castração devida à 'lalíngua'**. O gozo do corpo organizado por

\footnotetext{
* Talvez, aqui, Lacan não se refira à liberdade que remeta a uma ideia de um livre-arbítrio ou de uma escolha deliberada qualquer, pois os motivos - muitas vezes inconscientes -, e que levam o sujeitos a essas "escolhas", retiram o caráter deliberativo, apontando mais para uma determinação inconsciente. Ou seja, muitas vezes se utiliza o termo 'escolha' ou 'opção' por não se considerar a dimensão inconsciente do psiquismo. Entretanto, com a questão da divisão do sujeito (entre consciente e inconsciente) posta pela psicanálise, coloca-se a problemática quanto ao 'verdadeiro' agente da escolha: o eu (consciente e imaginário) ou o sujeito do inconsciente? Tal questão será retomada no capítulo em que trataremos sobre a identidade homossexual.

Trata-se de um neologismo criado por Lacan para se referir às primeiras articulações puramente significantes da criança, antes de assujeitar-se completamente à ordem simbólica da língua,
} 
lalíngua se torna "externo ao corpo", anômalo, idêntico ao gozo que opera no sintoma. O significante é a causa do gozo, mas é também o que o parcializa e o exterioriza de forma irremediável. A função fálica - da castração, lembremos - designaria, portanto, a captação do corpo e do sujeito na lalíngua.

O Outro, como lugar da fala, é hiante, sempre outro, sendo que não há Outro do Outro, ou que não há saber absoluto possível, e que o discurso não pode reforçar seu controle de alguma coisa que seja uma totalidade do saber. Há um furo no Outro, um limite interno na ordem simbólica.

Um ser (a mulher) vir a representar esse limite significa que não se pode dizer nada dele, ou então que se pode "dizer tudo", isto é, qualquer coisa, mas nada que fundamente uma definição universal. A linha oblíqua que barra o A ('La', em francês) de A mulher que "não existe" seria, portanto, homóloga da que barra o Outro ('Autre', em francês) da linguagem, (do mesmo modo que a do sujeito - \$ -, aliás). No campo do significante, esse ser não é totalmente indeterminado; o sujeito falante não é incorpóreo, posto que existe um corpo real. Esse limite interno do simbólico, que encontra seu significante no $S(A$ barrado), não se confunde com um outro que ele abarca: limite que separa o real do simbólico.

Em La troisième, Lacan fala do gozo do Outro (sexo), esse gozo dito feminino, que ele diz impossível, e tão "fora da linguagem, fora do simbólico", quanto o gozo fálico está "fora do corpo". O outro corpo substancial, que, como corpo, só se pode estreitá-lo, destruí-lo ou tirar dele um pedaço; esse corpo, o corpo real do parceiro, simboliza o Outro como lugar inapreensível do significante.

Mais, ainda, dizer que as mulheres são "não-todas" é dizer que o significante "mulher" conota aquilo que escapa ao discurso e faz presente o mais-além do que se pode atingir pela fala. Postar-se como mulher seria dar corpo a um aspecto da estrutura, isto é, ser, "em relação ao que se pode dizer do inconsciente, radicalmente Outro": a opacidade do real do corpo (desse "real com eu um corpo goza" e que é o mais estrangeiro ao simbólico como tal) surge, aqui, no lugar da hiância própria do simbólico.

do código. Ou seja, antes da ocorrência da Metáfora Paterna, com a inscrição do significante Nome-doPai, tal como visto mais acima. 


\title{
3: FAMÍLIA: ASPECTOS HISTÓRICO, SOCIOANTROPOLÓGICO E PSICANALÍTICO.
}

\begin{abstract}
Para tratar do fenômeno da família homoparental, faz-se necessário pontuar alguns elementos histórico-sociais fundantes da estruturação da família contemporânea, a fim de se compreender a estrutura e o contexto em que se insere a configuração familiar homoparental. Seguindo os referenciais teóricos que permeiam todo este trabalho, serão abordados, a seguir, alguns aspectos históricos, sócioantropológicos e psicanalíticos da instituição familiar.
\end{abstract}

\section{1: ASPECTOS HISTÓRICO E SOCIOANTROPOLÓGICO DA INSTITUIÇÃO FAMILIAR.}

A família nuclear contemporânea, composta elementarmente pelos personagens materno, paterno e filial, é derivada da família moderna surgida a partir do século XIX, com a ascensão dos ideais burgueses nas sociedades modernas daquela época. Até então, a estrutura da família era derivada da estrutura hierárquica das monarquias. Com a ascensão econômica e política da burguesia, a instituição familiar passa a ser representada primordialmente pela família nuclear: pai, mãe e filhos.

Desde o fim da Segunda Guerra Mundial, porém, esse núcleo começa a ser abalado justamente no que tinha de mais sólido, que eram as bases materiais para as relações de filiação. Os primeiros sinais de mudança foram a baixa das taxas de fecundidade, apresentadas em alguns países ocidentais desenvolvidos, sendo hoje fonte de preocupação de políticas demográficas, inclusive no que se refere à reposição da população. Logo em seguida, assisti-se a uma movimentação jurídica e cultural com uma vertiginosa queda da nupcialidade e, em contrapartida, o aumento do divórcio e da separação. Um menor número de filhos e uma maior rotatividade de situações 
conjugais, que acabam por provocar uma turbulência na noção de família como o que sustenta e organiza a sociedade.

Diante desse quadro, a base da família nuclear ruiu e sobre ela permanece o que sempre foi mais frágil: as relações conjugais. Sobre esse assunto, existem várias análises distintas. De um lado, existem aqueles que constatam uma crescente 'indiferenciação' entre os papéis masculinos e femininos. Conforme Elisabeth Badinter ${ }^{89}$ : "Há quinze anos [o livro foi escrito em 1986], apaga-se, pouco a pouco, na maioria das sociedades ocidentais, a linha que separa os campos da maternidade e da paternidade. Os homens começam a aprender diretamente o que significa ser pai, e a fazer para os filhos o que as mulheres fizeram no decorrer dos tempos". E, de outro, alguns autores argumentam que a grande modificação na organização familiar é provocada pela crise da autoridade paterna e do casamento, o que faz com que ocorra um estreitamento das relações consanguíneas entre mãe e filho e uma certa 'expulsão do masculino'. Como diz Héritier ${ }^{90}$ : "... Notamos, entretanto, que não se trata da supressão da família, nem consanguínea, nem elementar: esta última, de conjugal, se tornou, simplesmente, matrifocal".

Assim, segundo esta autora, a razão da crise da forma de socialização atual estaria na ruptura das ligações entre família e sociedade provocada pelo fato de a família passar a ficar centrada na figura da mãe. Enfatiza ainda a importância do surgimento de um tipo de 'solidariedade afetiva' entre mãe e filha, a qual pode indicar uma mudança significativa no modo de pensar os contratos sociais.

Seja como for, o que nos interessa salientar é o significado da mudança do papel da família nuclear na cultura contemporânea, principalmente no que se refere à radicalização do paradoxo constitutivo das sociedades democráticas ocidentais que, ao mesmo tempo em que valorizam a autonomia do indivíduo, se organizam a partir de instituições hierárquicas. Nesse contexto, a relação conjugal não se realiza mais a partir das normas fundantes da família moderna. Desde a proclamação da 'igualdade entre os sexos', o lugar do homem e da mulher na família estão em questão. Nestes últimos 30 anos, assistimos ao surgimento do "casamento-conversação", o qual se constitui a

\footnotetext{
${ }^{89}$ BADINTER, Elisabeth. - Um é o outro. RJ: Nova Fronteira, 1986.

90 HÉRITIER, Françoise. apud ARÁN, M. "Os Destinos Da Diferença Sexual Na Cultura Contemporânea".
} 
partir de uma eterna construção e desconstrução de laços, em que, mesmo que consideremos que o ponto de estabilidade seja a relação mãe-filho, como mostram as pesquisas mais recentes, é certo que a família nuclear não pode mais ser considerada uma base sólida, rígida ou permanente para construção identitária. No entanto, a família, qualquer que seja sua modalidade atual, continua a ser o referencial fundante na constituição do sujeito.

Segundo Roudinesco ${ }^{91}$, é possível historicamente distinguir três grandes períodos na evolução da instituição familiar: a família dita "tradicional", numa primeira fase, a família moderna, do final do século XVIII a meados do século XX, e a família contemporânea ou pós-moderna, datada a partir de 1960. A primeira delas, a família tradicional, servia acima de tudo para assegurar a transmissão de um patrimônio, tendo os casamentos arranjados pelos pais dos futuros esposos, em detrimento do desejo dos futuros esposos e repousando numa ordem do mundo imutável e inteiramente submetida a uma autoridade patriarcal, transposição da monarquia do direito divino. Já a família da segunda fase, a moderna, funda-se nos ideais do amor romântico, sancionando a reciprocidade dos sentimentos e os desejos carnais através do casamento. Valoriza também a divisão do trabalho entre os esposos, fazendo ao mesmo tempo do filho um sujeito cuja educação sua nação é encarregada de assegurar. A atribuição da autoridade torna-se então motivo de uma divisão incessante entre o Estado e os pais, de um lado, e entre os pais e as mães, de outro. Finalmente, a família contemporânea, surgida a partir dos anos 1960, une, ao longo de uma duração relativa, dois indivíduos em busca de relações íntimas ou realização sexual. Ao lado dessa nova forma, pode-se acrescentar as famílias recompostas, as monoparentais e a família homoparental, formada por um par de pessoas adultas do mesmo sexo biológico que criam e educam filhos. Estes filhos, em geral, advém da adoção, de relacionamento heterossexual anterior de um ou de ambos os componentes do par ou da utilização de técnicas científicas modernas de reprodução. De qualquer maneira, o modelo ou a estrutura da família nuclear moderna provavelmente continua operando nas composições familiares atuais, sendo entendido, por conseguinte, como uma construção econômica, política, social e cultural, demarcada temporal e espacialmente.

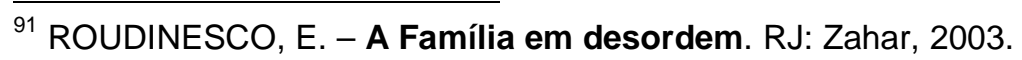


No entanto, como afirmava o antropólogo Lévi-Strauss em 1956, "a vida familiar apresenta-se em praticamente todas as sociedades humanas, mesmo naquelas cujos hábitos sexuais e educativos são muito distantes dos nossos. Após terem afirmado durante cinquenta anos que a família, tal como a conhecem as sociedades modernas, não podia ser senão um desenvolvimento recente, resultado de longa e lenta evolução, os antropólogos inclinam-se agora para a convicção oposta, isto é, a família , ao repousar sobre a união mais ou menos duradoura e socialmente aprovada de um homem, de uma mulher e de seus filhos, é um fenômeno universal, presente em todos os tipos de sociedades." (LÉVI-STRAUSS, 1956 apud ROUDINESCO, 2003, p.13).

Para Lévi-Strauss ${ }^{92}$, "o processo natural de filiação não pode seguir o seu curso senão integrado no processo social da aliança". Ou seja, a família conjugal não era um fenômeno natural, não era uma decorrência de um processo evolutivo e não devia sua existência fundamentalmente aos instintos ou ao amor entre seus membros. Suas bases estariam assentadas na aliança (o casamento), na filiação, na proibição do incesto e na troca, que definiriam a forma pelas quais os laços matrimoniais e a circulação das mulheres estabelecer-se-iam socialmente.

Segundo Roudinesco ${ }^{93}$, duas abordagens no estudo do fenômeno familiar são possíveis. A primeira privilegia o estudo vertical das filiações e das gerações, insistindo na continuidade dos saberes ou nas distorções entre os pais e os filhos, bem como na transmissão dos saberes e das atitudes herdadas de uma geração à outra. Essa é a linha de estudo da sociologia, da história e da psicanálise. A segunda abordagem, mais antropológica, privilegia o estudo horizontal ou comparativo das alianças, enfatizando que cada família provém sempre da união - logo, do estilhaçamento - de duas outras famílias. Para o primeiro caso, usa-se com mais frequência o termo "família", no outro "parentesco".

Grande parte dos estudos antropológicos indica que em todas as sociedades humanas encontra-se uma forma qualquer de família. Sua posição, dentro do sistema mais amplo de parentesco, pode oscilar muito, desde um lugar central e dominante (sociedade ocidental) até uma situação de reduzida importância (povos ágrafos), que

\footnotetext{
92 LÉVI-STRAUSS, C. - As estruturas elementares de parentesco. RJ: Vozes, 2003.

${ }^{93}$ ROUDINESCO, E., op. cit.
} 
dão maior destaque ao grupo de parentesco mais amplo do que à unidade representada por marido, mulher e filhos.

A família, em geral, é considerada o fundamento universal das sociedades, por se encontrar em todos os agrupamentos humanos, embora variem as estruturas e 0 funcionamento.

Se, originariamente, a família foi um fenômeno biológico de conservação e reprodução, transformou-se depois em fenômeno social. Sofreu considerável evolução até regulamentar suas bases conjugais conforme as leis contratuais, normas morais e religiosas.

Toda sociedade humana tem regras que abrangem as relações sexuais e a procriação de filhos, situando a criança em determinado grupo de descendência. Todavia, essas regras não são as mesmas em toda parte.

De modo geral, é o casamento que estabelece os fundamentos legais da família, mas pode haver famílias sem casamento.

A família, segundo Murdock ${ }^{94}$, é "um grupo social caracterizado pela residência comum, com cooperação econômica e reprodução". Para Lucy Mair ${ }^{95}$, ela consiste em "um grupo doméstico no qual os pais e filhos vivem juntos". Beals e Hoijer ${ }^{96}$ definem família como "um grupo social cujos membros estão unidos por laços de parentesco", ou ainda, "um grupo de parentes afins e seus descendentes que vivem juntos".

Os conceitos demonstram certa coesão entre os autores, no que se refere à família. Todavia, como toda exceção à regra, há famílias em que os cônjuges não moram juntos.

\subsection{1: Funções da Família.}

Entre as diversas funções da família, que têm variado através dos séculos, os estudiosos, segundo Prezotto ${ }^{97}$, apontam quatro básicas e quatro subsidiárias.

\footnotetext{
${ }^{94}$ MURDOCK (1969) apud PREZOTTO et. al. - Antropologia - uma introdução. SP: Atlas, 2007.

${ }^{95}$ LUCY MAIR (1970) apud id. Ibid.

${ }^{96}$ BEALS E HOIJER apud id. Ibid.

${ }^{97}$ PREZOTTO, op. cit., 2007.
} 
As funções básicas ou fundamentais, encontradas em todos os agrupamentos humanos, são:

1. Sexual: atende às necessidades sexuais permitidas por meio da institucionalização da união ou casamento, que estabelece um pai legal para os filhos.

2. Reprodução: visa à perpetuação por meio da prole. Mesmo em sociedades onde há liberdade sexual, a procriação de filhos é regulamentada com normas e sanções que legitimam a reprodução

3. Econômicas: assegura o sustento e a proteção da mãe e filhos, mas esses cuidados podem ser satisfeitos não só pelo pai-marido, como também pelos parentes consanguíneos. A organização e a divisão do trabalho entre o casal dá a cada um o direito sobre os serviços, bens e propriedades do outro.

4. Educacional: o cuidado das crianças é assunto de suma importância e universalmente reconhecido. Algum homem ou grupo deve arcar com a responsabilidade da educação. Para normalizar a transferência de status, de geração em geração, deve haver paternidade legal. Na educação das crianças faz-se necessária a combinação cooperativa do homem e da mulher.

As funções básicas da família podem ser desempenhadas de várias maneiras, dentro dos mais diversos sistemas culturais, tentando moldar as personalidades individuais.

Como agente educador, a família pode combinar duas funções específicas:

- Socializadora: na medida em que transmite a herança cultural e social, durante os primeiros anos de vida: linguagem, usos, costumes, valores, crenças (processo de endoculturação), preparando a criança para seu ingresso na sociedade.

- Social: quando proporciona a conquista de diferentes status, como o étnico, o nacional, o religioso, o residencial, o de classe, o político e o educacional.

SUBSIDIÁRIAS: Alguns autores incluem entre as funções da família zelar pelos aspectos religioso, jurídico, político e recreativo necessários à formação do indivíduo. 
O cuidado com os membros idosos e inválidos é também função universal da família. Praticamente não existe sociedade na qual a conexão indivíduo-família seja interrompida assim que cesse sua utilidade. Tendo prestado serviço a vida toda, os velhos, por sua vez, têm o direito de serem servidos. Entretanto, há sociedades que "aliviam" a família desse encargo, matando seus membros idosos ou deixando-os morrer, tal como ocorre entre os Esquimós, onde efetua-se o gerontocídio.

Outra função universal consiste na proteção dos interesses familiares contra estranhos. Esta função varia mais em grau do que em espécie. Em muitas sociedades, o indivíduo pode contar com o apoio de sua família, em qualquer circunstância ou complicações com estranhos, seja ou não culpado e custe o que custar a seus parentes. Em outras, o padrão de assistência é insignificante.

Vale ressaltar que todas essas variações podem ocorrer dentro de uma mesma sociedade.

A família, segundo Mello ${ }^{98}$, é instância fundamental na mediação entre indivíduo e sociedade. Esse papel de agente socializador é atribuído à família pelas mais diversas correntes de pensamento sociológico, do funcionalismo parsoniano ao marxismo crítico da Escola de Frankfurt, representado por Adorno e Horkheimer.

A família moderna (e contemporânea) destina-se à socialização amorosa das crianças, priorizando-se a intimidade e a privacidade do casal e seus filhos em detrimento dos vínculos de amizade e de vizinhança. Cabe aos pais solícitos e eficazes transmitir os valores, hábitos e tradições socialmente dominantes.

A família conjugal moderna é marcada por duas características: a afirmação da individualidade dos sujeitos na escolha de seus cônjuges, a partir dos ideais do amor romântico; e a maior independência dos novos casais em relação a suas famílias de origem.

Tal conceito de família nuclear, a que recorreu a história moderna do Ocidente, parte de um substrato biológico que costuma ligar a sexualidade, a procriação e a convivência a uma única unidade fundada a partir do matrimônio monogâmico (JELIN,

\footnotetext{
${ }^{98}$ MELLO, L. Novas Famílias -conjugalidade homossexual no Brasil contemporâneo. RJ: Garamond, 2005.
} 
$2004^{99}$ ). Todavia, dois processos fundamentam seu enraizamento social. Por um lado, um processo de naturalização que identifica a um tipo de família particular (o matrimônio monogâmico, que convive sob um mesmo teto, junto a seus filhos e filhas) como "natural", quer dizer, orientado por princípios biologicistas. Por outro lado, um processo de normalização que faz com que tal modelo de família adquira a nomeação de "normal" frente a outros tipos que são considerados desviados (JELIN, 2004). certo é que nas últimas décadas têm-se multiplicado e diversificado novas formas familiares, pondo em questão aquele tradicional modelo de família, com o qual encontrar um conceito de família costuma apresentar-se dificultoso uma vez que, como sustenta Guash, "a história da família é a história da mudança de sua definição e de suas funções" (GUASH ${ }^{100}$, 2002).

\subsection{2: Família e Sexualidade Contemporânea.}

Na sexualidade contemporânea, a procriação ocupa apenas um espaço reduzido e marginal. Experiência pessoal, fundamental para a construção do sujeito, a sexualidade passa a ser a esfera da intimidade e da afetividade, a partir da ocorrência de uma dissociação entre sexualidade e procriação.

Bozon $^{101}$ aponta que partir dos anos 1960, nos países desenvolvidos, ocorre a denominada "revolução contraceptiva", com a difusão dos métodos contraceptivos modernos, provocando uma reviravolta na maneira de encarar a fecundidade. $O$ medo de ter filhos demais - da geração do entre guerras - deu lugar ao desejo de tê-los em menor número. De agora em diante, a fecundidade é pensada como um projeto pessoal, cujo peso na organização de uma vida é muito mais leve, e a execução demanda preparo e reflexão. Escolhas são feitas: ter ou não ter filhos, o momento de tê-los, o intervalo desejado entre o primeiro e o segundo, ter ou não ter mais filhos. Essas decisões não escapam mais das mulheres (e de seus parceiros), podendo,

\footnotetext{
99 JELIN (2004) "Construções Discursivas sobre a Homoparentalidade". In MELLO, L. PISCITELLI, A., UZIEL, A. - Conjugalidades, Parentalidades e Identidades Lésbicas, Gays e Travestis. RJ: Garamond, 2004.

100 GUASH (2002) apud id. Ibid.

${ }^{101}$ BOZON, M. Sociologia da Sexualidade. FGV Editores, 2004.
} 
então, ser coordenadas junto às outras escolhas realizadas em outros domínios de suas vidas, especialmente o profissional.

Na percepção contemporânea da sexualidade, as relações sexuais destinadas à procriação passaram a ser pensadas como uma realidade totalmente distinta da própria procriação. Quer os indivíduos formem ou não um casal, qualquer atividade sexual já não é mais concebida sem proteção contraceptiva: de agora em diante, o próprio da sexualidade em geral é ser infecunda. Como a chegada de um filho não é mais uma dádiva de Deus, mas resultado de um desejo, de um cálculo, a passagem para uma sexualidade com a finalidade de procriar é fruto de uma decisão negociada entre parceiros, que leva à suspensão temporária da contracepção. Os momentos da vida em que se pratica uma sexualidade reprodutiva e aqueles em que se pratica uma sexualidade não-reprodutiva são absolutamente distintos. (grifos nossos)

A procriação com assistência médica, que começou a ser proposta no início dos anos 1980, é uma etapa suplementar da dissociação entre sexualidade e procriação. À inseminação artificial, correspondente a um modus operandi relativamente tradicional, acrescentou-se a fecundação in vitro, em que o encontro entre óvulos e espermatozóides é feito em laboratório, sob controle médico. Mesmo envolvendo um total de poucas pessoas (algumas dezenas de milhares de nascimentos no mundo), essa reprodução sem relações sexuais assume um papel simbólico importante e traduz muito bem a evolução contemporânea que aproximou a procriação da técnica, afastando-a da "natureza" e da sexualidade, com o desejo de ter filhos não mais inscrito, necessariamente, no calor do desejo sexual.

\subsection{3: As Famílias Brasileiras.}

Samara ${ }^{102}$ afirmou que as famílias com poucos integrantes já predominavam no Brasil desde os tempos da colônia, apesar do grande contingente de famílias extensas (que incluíam escravos e dependentes de tipos variados) que residiam principalmente

\footnotetext{
102 SAMARA, E. M. (2002), apud TOLEDO, L.C.C. - A família no discurso dos membros de famílias homoparentais. São Paulo, 2008. Tese (Doutorado) Instituto de Psicologia da USP.
} 
no Nordeste. No Brasil colonial o pátrio poder era "a pedra angular da família e emanava do matrimônio", sendo corroborado pelo Estado.

A descoberta das minas de ouro na década de 1690 deslocou o eixo econômico do Nordeste, atraindo pessoas para centros urbanos nos quais as mulheres passaram a exercer atividades profissionais fora do âmbito doméstico com mais frequência. No século XVII, as mulheres brasileiras que viviam no meio urbano passaram a trabalhar ocupando postos de trabalho abertos pela falta de escravos e pela migração masculina. Na segunda metade do século XIX, surgem vagas na indústria nacional e na burocracia estatal, e parte desses novos postos de trabalho também foram ocupados por mulheres.

Em 1836, as famílias nucleares - pai, mãe e filhos - predominavam na cidade de São Paulo, em detrimento das famílias extensas, entretanto, as famílias pobres eram majoritariamente chefiadas por mulheres (SAMARA, 2002).

Berquó $^{103}$ afirma que a família nuclear predomina no Brasil do final do século passado, ainda que o número de casais com filhos apresentava uma tendência declinante consistente. Na década de 80 cresceram significativamente uniões conjugais sem vínculos legais e os arranjos monoparentais.

Segundo o último censo do IBGE ${ }^{104}$ (BRASIL, 2001), considerando os números até o ano de 2007, pouco mais da metade das famílias brasileiras $(53,3 \%)$ eram nucleares. Entretanto, mais de 23 milhões de famílias $(46,7 \%$ do total de 50 milhões de famílias) tinham composições diversas: eram casais sem filhos, mulheres sem cônjuge com filhos, unipessoais ou de "outros tipos", nos termos do relatório.

Em 2007, o IBGE (CONTAGEM, 2007) divulgou os primeiros dados de um trabalho que indicava que $0,2 \%$ da população brasileira havia declarado espontaneamente ter companheiros do mesmo sexo atuando como chefes de casa nos 5.4335 municípios pesquisados. Foi a primeira vez na história do país que a Contagem da População do IBGE divulgou dados sobre casais homossexuais que vivem juntos. Segundo dados inferidos a partir do total da população brasileira em 190 milhões de

\footnotetext{
${ }^{103}$ BERQUÓ, E. (1998) apud TOLEDO, ibid.

104 BRASIL. IBGE (Instituto Brasileiro de Geografia e Estatística). Pesquisa Nacional Por Amostras De Domicílios -2001. Tabela 6.3. Rio de Janeiro, 2002. Disponível em: http://www.ibge.gov.br. Acesso em: 07 out. 2003. Apud TOLEDO, id. Ibid.
} 
habitantes, estima-se um total de 380 mil famílias compostas por casais homossexuais, com ou sem filhos.

\subsection{4: Família: universo de relações.}

Segundo Sarti ${ }^{105}$, antropóloga paulista, "uma abordagem possível de família é a que se define por uma história que se conta aos indivíduos desde que nascem e ao longo do tempo, por palavras, por gestos, atitudes ou silêncios e que será, por eles reproduzida e ressignificada, à sua maneira, dados os distintos lugares e momentos dos indivíduos na família". Vista como uma realidade que se constitui pela linguagem, socialmente elaborada e internalizada pelos indivíduos, a família torna-se um campo privilegiado para se pensar a relação entre o individual e o coletivo, portanto, entre mim e o outro.

Sarti parte da ideia de que a família se delimita, simbolicamente, a partir de um discurso sobre si própria, que opera como um discurso oficial. Embora culturalmente instituído, ele comporta uma singularidade. Cada família constrói sua própria história, ou seu próprio mito, entendido como uma formulação discursiva em que se expressam o significado e a explicação da realidade vivida, com base nos elementos objetiva e subjetivamente acessíveis aos indivíduos na cultura em que vivem. Os mitos familiares expressos nas histórias contadas, cumprem a função de imprimir a marca da família, herança a ser perpetuada.

Sarti busca pensar a família como uma realidade que se constitui pelo discurso sobre si própria, internalizado pelos sujeitos; uma forma de buscar uma definição que permita pensar como a família constrói, ela mesma, sua noção de si, supondo evidentemente que isso se faz em cultura, dentro, portanto, dos parâmetros coletivos do tempo e do espaço em que vivemos, que ordenam as relações de parentesco (entre irmãos, entre pais e filhos e entre marido e mulher). Sabemos que não há realidade humana exterior à cultura, uma vez que os seres humanos se constituem como tais em cultura, portanto, simbolicamente.

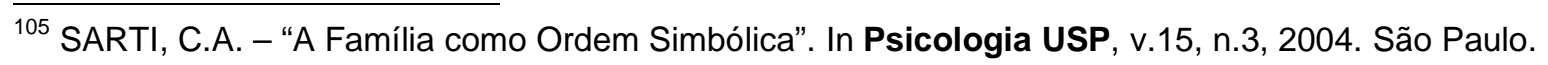


Quando ouvimos as primeiras falas, não aprendemos apenas a nos comunicar, mas, acima de tudo, captamos uma ordem simbólica, ou seja, uma ordenação do mundo pelo significado que lhe é atribuído, segundo as regras da sociedade em que se vive. O componente simbólico apreendido na linguagem é seu elemento constitutivo. Mauss $^{106}$, ao conceber a realidade social como um universo simbólico, ressaltou o caráter inconsciente dos costumes internalizados sem que os indivíduos percebam. Lévi-Strauss $^{107}$, em sua análise da obra de Mauss, mostrou que o costume passa a ser visto como da ordem da linguagem, pois os agentes não têm consciência de suas regras. Assim como a gramática da língua não é percebida pelos falantes, tampouco a gramática dos costumes, da vida social (é percebida) pelos seus agentes.

Nesse jogo entre o mundo exterior e o mundo subjetivo, as construções simbólicas operam numa relação especular. Assim acontece na família. O discurso social sobre a família se reflete nas diferentes famílias, como um espelho. Assim, cada família constrói seus mitos a partir do que ouve sobre si, do discurso externo internalizado, mas devolve um discurso sobre si que contém também sua própria elaboração, objetivando sua experiência subjetiva.

Essa formulação é evidentemente contrária à identificação da noção de família com a unidade de reprodução biológica (pai, mãe, filhos) e se contrapõe, ainda, à suposição da biologia humana como parte da ordem da natureza. Essa naturalização das relações sociais acontece de forma mais clara em relação à família do que a outras instituições sociais, porque a família é o espaço social onde se realizam os fatos da vida vinculados ao corpo biológico, como o nascimento, a amamentação, o crescimento, o acasalamento, o envelhecimento e a morte. O apelo à ordem da natureza para explicar os fatos humanos remete à dissociação entre biologia e cultura, com base na qual se assume que o corpo biológico existe independentemente da cultura, ao invés de pensá-lo como inscrito na e pela cultura.

A reordenação simbólica provocada pelas novas tecnologias reprodutivas e outros avanços tecnológicos, tais como a pílula anticoncepcional, que desvinculou sexualidade e reprodução, ao lado da descoberta do teste de DNA, que permite a comprovação da paternidade biológica, quebram a identificação do corpo biológico com

\footnotetext{
${ }^{106}$ MAUSS, Marcel. (1974) ([1923-1924]) apud SARTI, ibid.

107 LÉVI-STRAUSS, Claude. (1974) apud id. ibid.
} 
a ordem natural tão difundida em nossa cultura e provocam mudanças nas práticas e valores familiares, também mostrando onde se localizam as resistências. Sendo assim, é importante acolher e não condenar as famílias constituídas a partir das possibilidades das novas técnicas de reprodução, incluindo os filhos de casais homossexuais.

As mudanças são particularmente difíceis, uma vez que as experiências vividas e simbolizadas na família têm como referência definições cristalizadas de famílias socialmente instituídas pelos dispositivos jurídicos, médicos, psicológicos, religiosos e pedagógicos, enfim, os dispositivos disciplinares existentes em nossa sociedade, que têm nos meios de comunicação um veículo fundamental, além de suas instituições específicas. Essas referências constituem os "modelos" do que é e deve ser a família, fortemente ancorados numa visão de família como uma unidade biológica constituída segundo as leis da "natureza".

A já comentada naturalização das relações familiares, junto à sua transformação num modelo a ser seguido, faz da família um terreno fértil para um discurso normativo. Há frequentemente um "dever ser" no horizonte, referência positiva a partir da qual todo o resto torna-se "desvio" ou "anormalidade", quando não "patologia".

A família é o lugar onde se ouvem as primeiras falas, com as quais se constrói a auto-imagem e a imagem do mundo exterior. Assim, é fundamentalmente como lugar de aquisição de linguagem que a família define seu caráter social. Nela, aprende-se a falar e, por meio da linguagem, a ordenar e dar sentido às experiências vividas. $A$ família, seja como for composta, vivida e organizada, é o filtro através do qual se começa a ver e a significar o mundo. Esse processo que se inicia ao nascer estende-se ao longo de toda a vida, a partir dos diferentes lugares que se ocupa na família.

A família, inclusive para os adultos, continua tendo essa função de dar sentido às relações entre os indivíduos e servir de espaço de elaboração das experiências vividas. Essa concepção permite pensar o processo de "crescimento" na família como uma questão que diz respeito não apenas às crianças, mas a todos os seus membros, ao longo de suas vidas, na medida em que as experiências podem ser permanentemente re-elaboradas. "Crescer", assim, desvincula-se do mero processo biológico e constituise, também, em um processo simbólico. As condições favoráveis para que uma criança 
"cresça" ou um jovem se desenvolva na família se ampliam quando seu pai, sua mãe ou quem deles cuide possam se pensar, eles mesmos, como alguém em permanente crescimento, em cada novo lugar que ocupe na família.

A família não se define, portanto, pelos indivíduos unidos por laços biológicos, mas pelos significantes que criam os elos de sentido nas relações, sem os quais essas relações se esfacelam, precisamente pela perda, ou inexistência de sentido. Se os laços biológicos unem as famílias é porque são, em si, significantes. Ninguém se atreveria a contestar a força simbólica dos "laços de sangue" em nossa cultura ibéricoocidental, com os "nomes de família", as semelhanças físicas, os traços de personalidade (ou de caráter) "que se puxa" de algum parente próximo ou distante...

A família, como o mundo social, não é uma soma de indivíduos, mas sim um universo de relações. Embora comporte relações potencialmente equitativas, como aquelas entre o homem e a mulher, a família implica autoridade, pela sua função de socialização dos menores, definindo-se, assim, como um mundo de relações recíprocas, complementares e assimétricas.

A tensão entre os distintos discursos familiares denota a singularidade da família no mundo contemporâneo: ela é, ao mesmo tempo, auto-referida na sua construção do "nós" -nisto que constitui o mundo privado - e permanentemente influenciada pelo mundo exterior - público -, que lhe traz a inevitável dimensão do "outro", com a qual tem que lidar. Assim, a família constitui-se pela construção de identidades que a demarcam, em constante confronto com a alteridade, cuja presença se fará sentir insistentemente, forçando a abertura, mesmo quando persistirem as resistências. A família, então, constitui-se dialeticamente. Ela não é apenas o "nós" que a afirma como família, mas é também o "outro", condição da existência do "nós". Sem deixar entrar o mundo externo, sem espaço para a alteridade, a família confina-se em si mesma e se condena à negação do que a constitui, a troca entre diferentes.

Essa marca da família, a troca, remete à reviravolta feita por Lévi-Strauss na sua formulação sobre o tema, conhecida como teoria da aliança. Ao afirmar em favor do fundamento social (e não natural) da família, afirma que a família se constitui pela aliança (entre famílias previamente existentes) e não pela consaguinidade, que se torna uma consequência da aliança (o casamento). Se a família - instituição humana, 
portanto cultural - não incorpora o outro em suas relações, fechando-se em si mesma, nega o que constitui seu próprio fundamento: o rompimento do isolamento das relações naturais de consaguinidade para a expansão por meio dos laços sociais de aliança com o diferente, através do casamento. Assim, para Lévi-Strauss ${ }^{108}$, o tabu do incesto, "a" intervenção social, não é apenas uma regra negativa, uma proibição simplesmente, mas uma regra positiva, a da reciprocidade, que é abertura ao outro, condição de possibilidade de a humanidade desenvolver-se culturalmente.

\section{2: A INSTITUIÇÃO FAMILIAR SOB ENFOQUE PSICANALÍTICO.}

No campo psicanalítico, a estrutura familiar foi abordada através do estudo da subjetividade, tendo sido abordada mais diretamente por Freud no texto 'Romances Familiares' de 1909, e uma primeira abordagem de Lacan em seu texto de 1938, intitulado 'Complexos Familiares na Formação do Indivíduo'. Neste texto, Lacan ${ }^{109}$ trata da família enquanto "um grupo natural de indivíduos unidos por uma dupla relação biológica: por um lado a geração, que dá as componentes do grupo; por outro as condições de meio que postula o desenvolvimento dos jovens e que mantêm o grupo, enquanto os adultos geradores asseguram essa função.(...) A sua conservação e o seu progresso, por dependerem da sua comunicação" - da existência da linguagem, portanto - "são antes de tudo obra coletiva e constituem a cultura; esta introduz uma nova dimensão na realidade social e na vida psíquica. Esta dimensão especifica a família humana bem como, aliás, todos os fenômenos sociais no homem". Lacan desenvolve, em seguida, esse texto ressaltando a primazia da influência da Cultura sobre o aspecto biológico em relação à família, elencando, ainda, os fatores da hereditariedade psicológica, do parentesco biológico e a família primitiva como instituição, para, em seguida, tratar da psicologia familiar a partir do conceito de complexo.

\footnotetext{
108 LÉVI-STRAUSS (1981), apud id. ibid.

109 LACAN, J. "Os complexos familiares na formação do indivíduo" (1938). In Outros Escritos. RJ: Zahar, 2003, p. 29.
} 
Lacan considera que é possível reconhecer alguns traços do comportamento instintivo nas fases iniciais das funções maternas. Aponta, contudo, o quanto os "postulados espirituais", isto é, os ideais difundidos histórica e culturalmente, marcam o desenvolvimento do sentimento de paternidade, demonstrando o quanto "as instâncias culturais dominam as naturais, a ponto de não podermos considerar paradoxais os casos em que, como na adoção, umas substituem as outras ${ }^{110 ", ~(g r i f o ~ m e u) . ~}$

Continuando a tratar das funções da família, afirma que a psicologia concreta, com seu método de observação e análise, evidencia a estrutura hierárquica da família, reconhecendo nela o órgão privilegiado da coerção do adulto sobre a criança, coerção esta a que o homem deve uma etapa original e as bases arcaicas de sua formação moral. Em todos os grupos humanos, a família desempenha um papel primordial na transmissão da cultura. Embora as tradições espirituais, a manutenção dos ritos e costumes, a conservação das técnicas e do patrimônio sejam com ela disputados por outros grupos sociais, a família, segundo Lacan, prevalece na educação precoce, na repressão dos instintos e na aquisição da língua, legitimamente chamada materna. Através disso, ela rege os processos fundamentais do desenvolvimento psíquico, a organização das emoções segundo tipos condicionados pelo ambiente, que é a base dos sentimentos, segundo Shand; em termos mais amplos, ela transmite estruturas de comportamento e de representação cujo funcionamento ultrapassa os limites da consciência. De fato, é possível reconhecer nessas idéias os primórdios do conceito de grande Outro, que será posteriormente desenvolvido por Lacan.

A família estabelece entre gerações uma continuidade psíquica cuja causalidade é de ordem mental. Essa continuidade se revela o artifício de seus fundamentos nos próprios conceitos que definem a unidade da linhagem, desde o totem até o nome patronímico, não deixa por isso de se manifestar na transmissão, à descendência, de inclinações psíquicas que confinam com o inato, denominando esses efeitos, utilizando a expressão criada por Conn, de hereditariedade social, expressão, bastante imprópria em sua ambiguidade, mas que tem ao menos o mérito de assinalar como é difícil para o psicólogo não acentuar a importância do biológico nos fatos ditos de hereditariedade psicológica.

${ }^{110}$ LACAN, J. Op. Cit., p.30. 
Outra similitude, totalmente contingente, é vista no fato de que os componentes normais da família, tais como os observamos hoje em dia no Ocidente - o pai, a mãe e os filhos -, são os mesmos da família biológica. Essa identidade nada mais é do que uma igualdade numérica, e não uma verdade absoluta. Mas o pensamento fica tentado a reconhecer nela uma comunhão estrutural diretamente baseada na constância dos instintos, uma constância que então é preciso encontrar nas formas primitivas da família. Lacan vai afirmar que nessas premissas se fundamentaram teorias puramente hipotéticas da família primitiva, ora à imagem da promiscuidade observável nos animais por críticos subversivos da ordem familiar existente, ora segundo o modelo do casal estável, não menos observável na animalidade por defensores da instituição, tida como célula social. Tais teorias não se apoiam em nenhum fato conhecido. Segundo Lacan:

A pretensa promiscuidade não pode ser afirmada em parte alguma, nem mesmo nos chamados casos de casamento grupal: desde a origem, existem proibições e leis. As formas primitivas da família têm os traços essenciais de suas formas acabadas: autoridade, se não concentrada no tipo patriarcal, ao menos representada por um conselho, por um matriarcado ou por seus delegados do sexo masculino; modo de parentesco, herança e sucessão, transmitidos, às vezes distintamente, segundo uma linhagem materna ou paterna. Trata-se de famílias humanas, devidamente constituídas. Mas, longe de essas famílias nos mostrarem a pretensa célula social, vemos nelas, quanto mais primitivas são, não apenas um agregado mais amplo de casais biológicos, mas, sobretudo, um parentesco menos conforme aos laços naturais de consangüinidade ${ }^{111}$.

Quanto ao segundo aspecto, Lacan vai argumentar que "a família primitiva desconhece os laços biológicos do parentesco - um desconhecimento apenas jurídico, na parcialidade unilinear da filiação, mas também uma ignorância positiva, ou talvez um desconhecimento sistemático (no sentido de paradoxo da crença que a psiquiatria dá a esse termo), uma exclusão total dos laços que, apesar de só se poderem exercer em relação à paternidade, seriam observados em algumas culturas matriarcais. Além disso, afirma que o parentesco só é reconhecido por meio de ritos que legitimam os laços de sangue e criam, se necessário, laços fictícios: os fatos do totemismo, da adoção, da

\footnotetext{
${ }^{111}$ LACAN, J. Op. Cit., p.31.
} 
constituição artificial de um agrupamento agnato, como a zadruga eslava. Do mesmo modo, segundo nosso código, a filiação é demonstrada pelo casamento ${ }^{112 " .}$

O grupo reduzido composto pela família moderna, ao ser examinado, não parece uma simplificação, mas antes uma contração da instituição familiar. Ele mostra uma estrutura profundamente complexa, da qual mais de um aspecto se esclarece muito melhor pelas instituições positivamente conhecidas da família antiga do que pela hipótese de uma família elementar que não se apreende em parte alguma. Isso não quer dizer que seja ambicioso demais buscar nessa forma complexa um sentido que a unifique e, talvez, dirija sua evolução. Esse sentido é dado precisamente quando, à luz desse exame comparativo, apreende-se a reformulação profunda que conduziu a instituição familiar a sua forma atual; reconhecemos, ao mesmo tempo, que convém atribuí-la à influência preponderante aí assumida pelo casamento, instituição que se deve distinguir da família. Daí a excelência do termo "família conjugal" com que a designa Durkheim.

Lacan ainda demonstra que, "através da história dos povos patriarcais, vê-se afirmar dialeticamente, na sociedade, as exigências (morais) da pessoa e a universalização dos ideais: testemunho disso é o progresso das formas jurídicas que eternizou a missão vivida pela Roma antiga, tanto em potência quanto em consciência, e que se materializou na extensão já revolucionária dos privilégios morais de um patriarcado a uma plebe imensa e a todos os povos ${ }^{113 " \text {. }}$

Como decorrência, duas funções, nesse processo, irão se refletir na estrutura da própria família: a tradição, nos ideais patrícios, de formas privilegiadas de casamento, e a exaltação apoteótica trazida pelo cristianismo para as exigências da pessoa. A lgreja, tal como aponta Lacan, vai integrar essa tradição na moral do cristianismo, "ao colocar em primeiro plano, no laço do matrimônio, a livre escolha da pessoa, assim fazendo a instituição familiar dar o passo decisivo rumo a sua estrutura moderna, a saber, a inversão secreta de sua preponderância social em prol do casamento, inversão que se

\footnotetext{
112 LACAN, J. Op. Cit., p.32.

113 LACAN, J. Op. Cit.
} 
realizou no século $\mathrm{XV}$, com a revolução econômica da qual saíram a sociedade burguesa e a psicologia do homem moderno ${ }^{114 "}$.

Com efeito, são as relações da psicologia do homem moderno com a família conjugal que se propõem ao estudo do psicanalista; esse homem é o único objeto que ele realmente submeteu a sua experiência, e, se o psicanalista encontra nele o reflexo psíquico das condições mais originais do homem, não pode ter a pretensão de curá-lo de suas fraquezas psíquicas sem compreendê-lo na cultura que lhe impõe as mais altas exigências, e sem igualmente compreender sua própria posição diante desse homem no extremo da atitude científica.

Ora, em nossa época, mais do que nunca, afirmará Lacan que "é impossível compreender o homem da cultura ocidental fora das antinomias que constituem suas relações com a natureza e com a sociedade ${ }^{115 " .}$

Esse movimento subversivo e crítico em que o homem se realiza encontra seu germe mais ativo em três condições da família conjugal.

Por encarnar a autoridade na geração mais próxima e numa figura familiar, a família conjugal coloca essa autoridade ao alcance imediato da subversão criadora. Isso já é traduzido, para a observação mais comum, pelas inversões imaginadas pela criança na ordem das gerações, nas quais ela se coloca no lugar de um genitor de um dos seus pais.

Por outro lado, o psiquismo é não menos formado na criança pela imagem do adulto do que em oposição à coerção dele: esse efeito se opera pela transmissão do ideal do eu, e da maneira mais pura, do pai para o filho, comportando uma seleção positiva das tendências e dos dons, uma realização progressiva do ideal no caráter. É a esse processo psicológico que se deve a existência das famílias de homens eminentes, e não à pretensa hereditariedade, que conviria reconhecer em capacidades essencialmente relacionais.

Lacan indica que a família se reduziu a seu grupo biológico à medida em que foi integrando os mais altos progressos culturais, apontando, ainda, diversos efeitos psicológicos, segundo ele, decorrentes de um declínio social da imago paterna. "Um

\footnotetext{
114 LACAN, J. Op. Cit.

115 LACAN, J. Op. Cit.
} 
declínio condicionado por se voltarem contra o indivíduo alguns efeitos extremos do progresso social; um declínio que se marca, sobretudo em nossos dias, nas coletividades mais desgastadas por esses efeitos: a concentração econômica, as catástrofes políticas ${ }^{116 " . ~ E s s e ~ d e c l i ́ n i o ~ d a r-s e-i a ~ p e l o ~ r e l a t i v o ~ c r e s c i m e n t o ~ d a s ~}$ exigências matrimoniais, ligadas à maior equivalência de direitos das mulheres esposas - nas relações conjugais, consequência da maior participação da mulher na esfera pública da sociedade.

Para Lacan, esse declínio constitui uma crise psicológica, supondo uma possível relação dessa crise com o aparecimento da própria psicanálise, revelada pelas formas de neuroses predominantes no fim do século passado, sendo estas intimamente dependentes das condições da família daquela época. A "experiência" (clínica) leva Lacan "a apontar sua determinação principal na personalidade do pai, sempre de algum modo carente, ausente, humilhada, dividida ou postiça”. Lacan, nesse momento de sua produção teórica, fiava-se numa abordagem mais sociológica, a qual, no decorrer de seu ensino, será abarcada em sua concepção do registro Imaginário. "É na ordem original de realidade constituída pelas relações sociais que convém compreender a família humana. Se, para assentar esse princípio, recorre-se às conclusões da sociologia, embora a soma dos fatos com que ela o ilustra ultrapasse nosso tema, é porque a ordem de realidade em questão é o objeto próprio dessa ciência ${ }^{117 " ~ e ~ e ́ ~ n e s s a ~}$ suposta objetividade que, assim Lacan acredita, os resultados da pesquisa psicológica da família e do indivíduo poderão ser julgados. "Com efeito, na medida em que rompe com as abstrações acadêmicas e visa, seja na observação do behaviour, seja pela experiência da psicanálise, dar conta do concreto, essa pesquisa, especialmente quando se exerce sobre os fatos da "família como objeto e circunstância psíquica"18", nunca objetiva instintos, mas sempre complexos. É preciso reconhecer este caráter essencial do objeto estudado, traduzido em termos psicológicos, mas conforme ao princípio preliminarmente formulado, quer seja, a família e seu condicionamento por fatores culturais, à custa dos fatores naturais. O objeto de interesse desta abordagem, o complexo, reproduz uma certa realidade do ambiente, vinculando de forma fixa um

\footnotetext{
${ }^{116}$ LACAN, J. Op. Cit.

117 LACAN, J. Op. Cit.

${ }^{118}$ LACAN, J. Op. Cit., p. 33.
} 
conjunto de reações do indivíduo que pode concernir a todas as funções orgânicas, desde a emoção até a conduta adaptada ao objeto a que se dirige.

Ao longo do texto, Lacan seguirá tratando dos diferentes complexos que se apresentam na criança ao longo de seu desenvolvimento, tais como o do desmame, o de intrusão e o de Édipo, e, consequentemente, o de castração. Entretanto, foge ao objetivo deste trabalho o aprofundamento de cada um desses elementos. Mas, sabe-se que o complexo de castração será fundamental para a reformulação lacaniana da teoria do Édipo, tal como abordados no segundo capítulo deste trabalho. 


\title{
4: FAMÍLIA HOMOPARENTAL: POSIÇÕES PSICANALÍTICAS E SÓCIO- ANTROPOLÓGICAS.
}

\begin{abstract}
"Podemos rejeitar o evolucionismo mas não devemos esquecer ter sido ele que fundiu os 'nós' e os 'outros', os civilizados e os bárbaros numa só espécie. A ideia da evolução serviu como uma armação provisória para unir conjuntos distintos, antes que pudessem ser incorporados num mesmo todo. Agora achamos esse todo bastante informe e reclamamos um estudo das diferenças. Mas não teria sido possível estudar as diferenças antes que a unidade fundamental fosse estabelecida".
\end{abstract}

(Louis Dumont $^{119}, 1985$, pp. 187)

Este capítulo irá abordar o fenômeno da homoparentalidade, ou seja, a paternidade e a maternidade exercida por indivíduo ou pela parceria homossexuais, objeto central deste estudo, após terem sido abordadas as categorias de identidade sexual e de gênero, a sexuação na psicanálise e a família como instituição. Neste capítulo, considerar-se-ão os aspectos histórico, político e sócio-culturais deste fenômeno.

A primeira parte trata do aspecto histórico e político e das especificidades da homoparentalidade. Em seguida, tratar-se-á das repercussões culturais e do debate que tal tema suscita no âmbito político e jurídico, como forma de compreender as situações, entraves e obstáculos que os casais e as famílias homoparentais encontram atualmente em nossa sociedade, na busca de reconhecimento social.

\section{1: A FAMILIA HOMOPARENTAL: BREVE HISTÓRICO POLÍTICO DE UM "NOVO" FENÔMENO DA CULTURA HODIERNA.}

Como visto em capitulo anterior, com a existência de uma "crise da família patriarcal”120, a partir do século XIX, nos países desenvolvidos- Europa, EUA e centros

\footnotetext{
${ }^{119}$ DUMONT, L. - O Individualismo - uma perspectiva antropológica da ideologia moderna. Trad. Álvaro Cabral. RJ: Rocco, 1985.
} 
urbanos desenvolvidos brasileiros e de outros países em desenvolvimento (CASTELLS $\left.{ }^{121}, 2000\right)$, surgem novos padrões de relacionamento entre os parentes no fim do século passado. As relações familiares estariam se tornando mais igualitárias e menos hierárquicas (BERQUÓ $\left.{ }^{122}, 1998\right)$.

À medida em que era alçada à condição de estrutura familiar hegemônica nos países desenvolvidos e nos centros urbanos desenvolvidos dos países periféricos, a família nuclear tornou-se uma referência normativa, um modelo a ser seguido e incentivado por médicos, juristas, psicólogos e outros profissionais representantes dos discursos disciplinares. Uziel ${ }^{123}$ afirma que a ideia de uma família natural, formada por pai, mãe e filhos, prossegue como uma referência marcante, alçada à condição de arranjo ideal (em detrimento dos demais) e não como uma possibilidade dentre outras.

$O$ que se refere especificamente às famílias homoparentais, Roudinesco ${ }^{124}$ afirma que elas teriam se tornado um fato mais visível socialmente em todo o mundo a partir do momento em que seus membros puseram-se a lutar por seus direitos em vários países. Quanto à questão do desejo de gays e lésbicas de serem pais, afirma que esse manifesta-se publicamente a partir da experiência de californianos, nos anos de 1965-70, reivindicando "um grande desejo de normatividade que foi acolhida como a pior das feridas (ofensa) infligidas à ordem simbólica." Essas experiências foram se multiplicando a partir de 1975 à medida em que a luta em favor da descriminalização da homossexualidade ocupava espaço cada vez maior nos movimentos de emancipação de "minorias". (que inclui movimentos feministas, negros e de outras etnias).

Em 1996, na França, foi criado o termo 'homoparentalidade' (homoparentalité, em francês) pela 'Associação dos Pais e Futuros Pais Gays e Lésbicos' (APGL), uma organização do movimento homossexual francês. Este termo não costuma ser utilizado no mundo anglófono - e sobretudo nos EUA -, onde se prefere falar de lesbian and gay families ou de lesbian and gay parenthood. Isso se deve ao fato de que os

\footnotetext{
120 Patriarcalismo: estrutura familiar caracterizada "pela autoridade, imposta institucionalmente, do homem sobre a mulher e filhos, no âmbito familiar.

${ }_{121}$ CASTELLS (2000), apud TOLEDO, L. C. C. A família no discurso dos membros de famílias homoparentais. Tese (Doutorado) IP-USP, São Paulo, 2008.

122 BERQUÓ (1998), apud TOLEDO, op. cit.

123 UZIEL, A.P. - Homossexualidade e Adoção. RJ: Garamond, 2007.

124 ROUDINESCO, E. op. cit.
} 
homossexuais norte-americanos recusam qualquer denominação de origem psiquiátrica, preferindo um vocábulo mais gaiato, centrado no gênero.

Auerbach e Silverstein ${ }^{125}$ dividiram em fases o processo de afirmação da homoparentalidade. $\mathrm{Na}$ primeira delas, os filhos seriam frutos de relações heterossexuais anteriores. Em seguida, as lésbicas das décadas de 70 e 80 decidiram ter filhos. Nos anos seguintes, décadas de 80 e 90, os gays seguiram o exemplo das lésbicas. Essas famílias enfrentaram (e seguem enfrentando) uma oposição aguerrida às suas demandas e à sua existência.

No campo político, foi preciso esperar os anos 1970 - depois dos trabalhos de Foucault - mais especificamente a publicação do primeiro volume da sua 'História da Sexualidade: a vontade de saber', e os grandes movimentos de liberação sexual, para que a homossexualidade passasse a ser vista não como doença, mas como prática sexual totalmente à parte, marcada aliás pela diversidade. Falou-se das homossexualidades, e não mais da homossexualidade, para significar que esta não era mais uma estrutura imutável, mas um componente multiforme da sexualidade humana.

Em 1974, sob pressão dos movimentos gays e lésbicos, a Associação Psiquiátrica Americana (APA) decidiu, após um referendo, retirar a homossexualidade da lista das doenças mentais do DSM.

No interior do movimento psicanalítico, mesmo após publicação das posições freudianas de vanguarda em seus "Três Ensaios", de 1905 e de sua posição de neutralidade, mas publicamente contrária à discriminação, os discípulos e herdeiros de Freud se mostraram de uma intolerância extrema para com a homossexualidade. Roudinesco ${ }^{126}$ afirma que Anna Freud acreditava que um tratamento clínico bemsucedido consistia na condução de um homossexual para o caminho da heterossexualidade. Os kleinianos consideraram que a homossexualidade ora se explicava por uma "identificação com um pênis sádico", ora por um "distúrbio esquizóide da personalidade, acompanhado ou não de manifestação de defesa contra uma paranóia excessiva". Em momento algum, nenhum analista de orientação kleiniana se levantou para criticar a discriminação de que os homossexuais eram vítimas, segundo

\footnotetext{
${ }^{125}$ AUERBACH E SILVERSTEIN apud UZIEL, Op. Cit.

${ }^{126}$ ROUDINESCO, E. op. cit.
} 
Roudinesco ${ }^{127}$. Apesar de ter alertado os psicanalistas homofóbicos de plantão que suas resistências não deveriam representar a opinião da Psicanálise enquanto disciplina Roudinesco (2002 citado por GROSSI ${ }^{128}$, 2003), ainda assim encontram-se afirmações do tipo: "os homossexuais sofrem de uma patologia narcísica a qual fará excluir toda relação para com o outro"; "o pai homossexual tratará seu filho como um fetiche no sentido psicanalítico do termo"; "a criança não será desejada por ela mesma , mas como um modo de expor aos olhos dos outros a negação da infertilidade do casal homossexual". Pode-se pensar em homofobia na ciência? Ou deve-se vir em socorro de Freud e pensar na homofobia dos psicanalistas?

Ao fundar a EFP em 1964, Roudinesco ${ }^{129}$ afirma ainda que Lacan, contrariamente aos seus colegas da IPA, possibilitou que homossexuais se tornassem analistas. Entretanto, ao contrário de Freud, via a homossexualidade como uma perversão em si: não uma prática sexual perversa, mas a manifestação de um desejo perverso, comum aos dois sexos.

A emergência, no final da década de 90, do reconhecimento civil da conjugalidade homossexual, segundo autores que tem refletido sobre a história da homossexualidade e da família, assinala uma etapa significativa de questionamento aos modelos ocidentais modernos de parentesco, marcados pelo modelo de um conjunto formado pela díade do casal heterossexual com sua prole. Há várias explicações para esse desejo de conjugalidade entre indivíduos do mesmo sexo. Alguns autores enfatizam a emergência do modelo individualista moderno constituído, particularmente, por lésbicas e gays vivendo em grandes metrópoles mundiais, que assumiriam modelos de fechamento no conforto do lar 'tecnologizado' dos casais DIWC ('Double Income Without Children', isto é, duplo salário sem filhos). Outros ressaltam o impacto da AIDS sobre a comunidade gay, que teria sido um propulsor da busca por conjugalidade em relações homoeróticas como forma de autoproteção à contaminação. A forte demanda por reconhecimento legal destas uniões, através das leis de parceria civil, seria uma ${ }^{127}$ Id., ibid.

${ }^{128}$ GROSSI (2003) apud TEIXEIRA FILHO, F. S.; TOLEDO, L. G. e GODINHO, P. H.. "A homofobia na representação de mães heterossexuais sobre a homoparentalidade". In GROSSI, M. et al. (org.) Conjugalidades, Parentalidades e Identidades Lésbicas, Gays e Travestis. RJ: Garamond, 2004.

${ }^{129}$ ROUDINESCO, E. op. cit. 
das conseqüências dos inúmeros casos dramáticos de pessoas que perderam, por causa da AIDS, além do companheiro, moradia e renda, devido à inexistência de amparo legal para a união entre dois indivíduos do mesmo sexo.

Mas se a busca de conjugalidade homossexual masculina tem sido interpretada como uma "proteção" à AIDS, as interpretações sobre a conjugalidade lésbica são bastante diferentes, como constatou Heilborn ${ }^{130}$. Seu estudo se detém na comparação das conjugalidades heterossexual, gay e lésbica, de classes médias brasileiras e na assunção do modelo individualista moderno pelas lésbicas, mostrando que o ideal de conjugalidade igualitário não é um dado recente, mas um projeto consolidado nesta comunidade homossexual.

Quando os casais homossexuais franceses obtiveram, em 1999, um primeiro reconhecimento legal de sua vida comum, certos psicanalistas lacanianos adotaram, como os colegas da IPA, uma posição de especialistas. Pierre Legendre, segundo Roudinesco ${ }^{131}$, fez parte da coorte.

Do ponto de vista simbólico, afirmavam que a invenção da família dita homoparental arriscava reavivar o grande terror de uma possível supressão da diferença sexual, que, como foi visto, surgira no final do século XIX no momento do declínio da antiga autoridade patriarcal.

Os novos pais gays e lésbicos, no entanto, não pretendiam questionar os dois grandes interditos fundadores das leis do parentesco: proibição do incesto, interdito do distúrbio das gerações.

Zambrano $^{132}$ afirma que as questões que a homoparentalidade coloca para a antropologia atingem um dos campos de estudo mais tradicionais da disciplina, o da família e do parentesco. Coloca também que a psicanálise necessitaria enfrentar e colocar essas novas possibilidades dentro do seu corpo teórico, relativizando a idéia de serem a subjetivação e a construção do simbólico dependentes da diferença dos sexos. Da mesma maneira, o direito ver-se-ia impelido a acompanhar essas configurações

\footnotetext{
${ }^{130}$ HEILBORN, Maria Luisa. Dois é par: conjugalidade, gênero e identidade em contexto igualitário. Rio de Janeiro: Garamond, 1992.

${ }_{131}$ ROUDINESCO, E. op. cit.

${ }^{132}$ ZAMBRANO, Elisabeth. (2006) Loc. cit.
} 
criando novas possibilidades legais de conjugalidade e filiação de forma a não deixá-las à margem da proteção do Estado.

Com os debates ocorridos na França nos anos anteriores à criação do PACS (Pacte Civil de Solidarieté)- projeto de lei francês, em que se regulariza a questão das uniões homossexuais estáveis, aprovado em 1998(a confirmar), em Paris -, ficou evidente a influência das formulações teóricas da psicanálise. Além das questões referentes à conjugalidade, foram abordadas as possibilidades da adoção e utilização das novas tecnologias reprodutivas pelos homossexuais, o que acabou por se tornar o foco central das discussões. Entre os profissionais do "campo psi" (psicologia, psiquiatria, psicanálise) que se manifestaram publicamente sobre o tema (e ainda se manifestam atualmente), principalmente na França, Mehl ${ }^{133}$ identifica três correntes de pensamento.

A primeira é contrária ao reconhecimento do casal e da parentalidade homossexual pela sociedade e pela legislação. Misturando religião e psicanálise, considera a homossexualidade uma questão privada e uma perversão e, por isso, não merecedora de reconhecimento legal. Esse discurso, mais conservador, utiliza argumentos que atuam em defesa da família tradicional e se apóiam nas tradições e crenças religiosas, embora se apresentem revestidas de um vocabulário psicanalítico ou psicológico.

A segunda corrente não opina sobre o casal e a homossexualidade, mas se opõe à homoparentalidade sob o argumento de que a diferença dos sexos está no núcleo das representações identitárias, afirmando ser impossível para as crianças imaginar que possam ter sido concebidas fora dessa diferença. Em decorrência disso, a criação de crianças por pessoas do mesmo sexo seria uma destruição dos fundamentos antropológicos da constituição do parentesco, da família e da procriação. Partem do pressuposto de que os homossexuais negam a diferença dos sexos e não permitem aos filhos um contato adequado com o sexo oposto, o que é uma afirmação sem fundamento empírico.

A última das correntes é composta por pessoas contrárias à utilização de um saber psicológico e psicanalítico para se posicionar contra novas formas de

\footnotetext{
${ }^{133}$ MEHL, (2003) apud ZAMBRANO op. cit., 2006.
} 
experimentação familiar. Consideram não caber aos psicanalistas fazerem julgamentos morais a respeito de tipos de famílias já existentes na nossa sociedade, sendo preciso reconhecer as novas formas de família, em favor de uma pluralidade de organizações contemporâneas. O argumento teórico utilizado por essa corrente para refutar a importância da diferença dos sexos dos pais para o bom desenvolvimento da criança diz que a identidade não se restringe apenas à identidade sexual e que a percepção do outro, a alteridade, não está baseada apenas na diferença do sexo. Argumentam, também, que as normas mudam, têm uma história, e seu conteúdo varia de acordo com o tempo e o lugar, não podendo ser fixadas pelas posições ideológicas do momento, em flagrante desrespeito aos resultados das pesquisas, às normas democráticas e aos direitos humanos.

Torna-se evidente, a partir dos posicionamentos acima, quais são os principais argumentos utilizados nas discussões: a ameaça de destruição da sociedade e os prováveis prejuízos causados às crianças pertencentes à famílias homoparentais. Sustentando ambos, está a necessidade da diferença dos sexos.

Roudinesco, afirma, no entanto, que, "para além de todas as distinções que podem ser feitas entre o gênero e o sexo, o materno e o feminino, a sexualidade psíquica e o corpo biológico, o desejo de um filho sempre terá algo a ver com a diferença dos sexos. Demostram isso as declarações dos homossexuais que sentem a necessidade de dar aos filhos por eles criados uma representação real da diferença sexual, e não apenas duas mães das quais uma desempenharia papel de pai, ou dois pais dos quais um se disfarçaria de mãe" (ROUDINESCO, 2003: 197 - grifo nosso).

Mello ${ }^{134}$ afirma que, no Brasil, particularmente nos últimos 25 anos, lésbicas e gays emergem na cena política e questionam a universalidade dos valores heterossexistas vigentes. "São homens e mulheres que, transcendendo os limites de classe, sexo, gênero, raça, etnia, religião, geração, nacionalidade e orientação ideológica, trazem em seus pensamentos, intenções e atos, ainda que de forma nem sempre intencional e deliberada, a marca im(ex)plícita da transgressão, desafiando

\footnotetext{
${ }^{134}$ MELLO, Luiz. (2005) -“Outras famílias: a construção social da conjugalidade homossexual no Brasil”. In Revista. Cadernos Pagu, n.24, jan./jun. Publicação do Núcleo de Estudos de Gênero - Pagu, da Universidade de Campinas - Unicamp. Campinas, 2005. (Acessado através do buscador 'Google Acadêmico', palavra-chave: 'família homoparental', em 14/02/2010).
} 
fundamentos básicos da normatividade social por meio de suas vivências amorosas e sexuais". Em particular, deve-se registrar que o ano de 1995 é um marco para a luta homossexual por reconhecimento de direitos civis, tendo em vista três fatos: a realização, no mês de junho, no Rio de Janeiro, da 1a Conferência da Associação Brasileira de Gays, Lésbicas e Travestis (ABGLT) e da 17ª Conferência da International Lesbian and Gay Association (ILGA) e, principalmente, a apresentação, pela então Deputada Marta Suplicy, do Projeto de Lei no 1151/95, explicitamente inspirado na legislação sueca, que institui a união civil entre pessoas do mesmo sexo, atendendo demanda de grupos homossexuais organizados do País. Especialmente a partir da publicização deste projeto de lei, os meios de comunicação de massa, liderados pela televisão, passaram a dar cobertura ostensiva - e muitas vezes sensacionalista - à discussão sobre a união civil entre pessoas do mesmo sexo, denominando-a, a contragosto da autora da proposição, de "casamento gay".

Segundo Mello $^{135}$, com a apresentação do referido Projeto setores expressivos da sociedade brasileira associam-se a um inédito diálogo, nem sempre fácil, acerca da prerrogativa de lésbicas e gays usufruírem de direitos humanos e de cidadania próprios ao âmbito da conjugalidade e da parentalidade. À medida que tais debates se ampliavam em extensão e profundidade, ficava cada vez mais claro que, pela primeira vez na história brasileira, o Congresso Nacional e a sociedade em geral estavam perante uma reivindicação de direitos que implicava o questionamento da norma heterocêntrica que desde sempre estruturara os pressupostos éticos, morais e legais relativos à família patriarcal. É nesse contexto geral que as discussões acerca do Projeto podem ser compreendidas como um indicativo de que lésbicas e gays, na qualidade de cidadãos, percebem-se discriminados e excluídos do usufruto de direitos humanos fundamentais na esfera da família, o que implicaria a negação de sua dignidade e intrínseca humanidade, já que seus vínculos afetivo-sexuais estáveis não contam com a proteção legal do Estado, embora não sejam juridicamente definidos como ilegais, nem cientificamente reconhecidos como patológicos.

$\mathrm{Na}$ América Latina, cabe ressaltar o papel pioneiro da Argentina, onde se destacam a aceitação da lei de União Civil na Cidade Autônoma de Buenos Aires, em

${ }^{135}$ Idem, ibid. 
dezembro de 2002, e, em 2004, a apresentação do projeto de lei perante o Congresso para a sanção da União Civil a nível nacional, incluindo os direitos à criação e adoção.

\section{2: "FAMÍLIA HOMOPARENTAL": A DESIGNAÇÃO E SUA FORMAÇÃO.}

Como visto acima, o temo 'homoparentalidade' surgiu na França, em 1996, cunhado pela 'Associação dos Pais e Futuros Pais Gays e Lésbicos' (APGL).

De acordo com Zambrano ${ }^{136}$, o uso do termo "família homoparental" costuma ser objeto de muitos questionamentos, pois coloca o acento na "orientação sexual" 'identidade sexual', conforme categoria utilizada neste trabalho - (homoerótica) dos pais/mães e a associa ao cuidado dos filhos (parentalidade). Essa associação (homossexualidade dos pais/mães e cuidado com os filhos) é, justamente, o que os estudos sobre homoparentalidade se propõem a desfazer, demonstrando que homens e mulheres homossexuais podem ser ou não bons pais/mães, da mesma forma como homens e mulheres heterossexuais. Os estudos demonstram que é a capacidade de cuidar e a qualidade do relacionamento com os filhos o determinante da boa parentalidade, e não a orientação sexual dos pais.

Entretanto, o seu emprego é estratégico e se justifica pela necessidade de colocar em evidência uma situação cada vez mais presente na sociedade atual. Ao nomear um tipo de família até então sem nome, permite-se que ela adquira uma existência discursiva, indispensável para indicar uma realidade, possibilitando o seu estudo e, principalmente, sua problematização (DE SINGLY ${ }^{137}$, 2000). Favorece, ao mesmo tempo, a emergência de um campo de luta político onde as demandas de (homo)parentalidade ficam fortalecidas.

Recusar chamar de "família" esses arranjos, negar a existência de um vínculo intrafamiliar entre os seus membros (ainda que esses vínculos possam ter um aspecto extremamente polimorfo e variado) e impedir que tenham um estatuto legal, significa "fixar" a família dentro de um formato único, que não corresponde à diversidade de expressões adotadas por ela nas sociedades contemporâneas.

\footnotetext{
136 ZAMBRANO, E. (2006), loc. cit.

137 DE SINGLY (2000) apud ZAMBRANO, op. cit., (2006)
} 
Mas, questiona-se, como ter um filho sendo homossexual? Segundo Grossi ${ }^{138}$, a literatura da área lista as seguintes formas de filiação:

1. Terem tido filhos em relações heterossexuais anteriores à "descoberta" ou antes de "assumir" a homossexualidade.

2. Adoção por um dos parceiros, pois até então apenas na Holanda é reconhecida a adoção por um casal homossexual. Ver-se-á, mais adiante, como está esta questão no Brasil, no âmbito legal e jurídico.

3. Procriação com um terceiro indivíduo fora da relação de conjugalidade, através das novas tecnologias reprodutivas (inseminação artificial por doador desconhecido para lésbicas ou 'barriga de aluguel' para gays).

4. Co-parentalidade entre lésbicas e gays, que pode ser tanto de dois casais, como de um casal de lésbicas com um gay ou um casal de gays com uma lésbica.

E como definir este modelo de família?

Dir-se-á em princípio que a presença de dois papais e/ou duas mamães, na criação dos filhos e das filhas, não é um fator específico, já que tal estrutura também é compartilhada, por exemplo, pelos modelos co-parentais. Pode-se definir, então, a família homoparental como toda família na qual as pessoas (ou algumas das pessoas) a cargo da criação dos filhos ou das filhas não se inscrevem no modelo de heterossexualidade obrigatório. Isto contempla às pessoas travestis, transexuais e intersexuais, quanto a sua identidade de gênero e sexo (biológico), e às pessoas homossexuais, quanto a sua orientação sexual (ZAMBRANO ${ }^{139}$, 2006). No entanto, para os fins deste estudo, considerar-se-á, a princípio, as parcerias formadas por sujeitos de identidades homossexuais - gays ou lésbicas - que desempenham função parental, com ou sem parceiro, mas que mantém uma identidade de gênero estável e coerente a seu sexo biológico.

\footnotetext{
${ }^{138}$ GROSSI, M.P. - "Gênero e parentesco: famílias gays e lésbicas no Brasil". In Revista. Cadernos Pagu, n.21. Publicação do Núcleo de Estudos de Gênero - Pagu, da Universidade de Campinas Unicamp. Campinas, 2003. (Acessado através do buscador 'Google Acadêmico', palavra-chave: 'família homoparental', em 14/02/2010).

${ }^{139}$ ZAMBRANO (2006), op. cit.
} 


\section{3: O DEBATE SOCIOPOLÍTICO E JURÍDICO A RESPEITO DA FAMÍLIA HOMOPARENTAL: UMA LUTA CONTRA A HOMOFOBIA.}

Atualmente, as famílias homoparentais ainda não são consideradas publicamente enquanto tais, não só na ordem jurídica, mas tampouco na ordem simbólica. Isso implica uma necessidade de criação e reinvenção dos lugares que se ocupam nas configurações familiares, já que como consequência seus vínculos se distanciam do modelo familiar de referência tradicional, baseado no heterocentrismo.

Todas essas novas formas de pensar a conjugalidade bem como a parentalidade revelam inquietações em torno do lugar simbólico e jurídico ocupado pela criança. Os debates a respeito da família homoparental respondem sem dúvida à dita inquietação. Correntemente se costuma colocar que uma criatura necessita de um pai e de uma mãe como figuras fundamentais para sua criação, tal como se sustenta inclusive na Convenção sobre os Direitos da Criança (CADORET ${ }^{140}$, 2003), na Argentina - Estatuto da Criança e do Adolescente (ECA), no Brasil. Que ocorre, então, com a homoparentalidade? Quais são as crenças sustentadas em torno de tal modelo familiar?

Uma série de estudos foram realizados, a partir da década de 70, principalmente nos Estados Unidos, com o intuito de verificar a adequação do funcionamento das famílias homoparentais. Tais estudos foram motivados, principalmente, pela disseminação deste modelo de família, a partir daquele período, e pela necessidade de fornecer elementos para responder aos cada vez mais frequentes questionamentos judiciais, principalmente aqueles relacionados à preocupação com os problemas psicológicos que tais crianças, porventura, apresentariam com sua futura orientação sexual e com a maneira pela qual estas crianças lidariam com o estigma social associado ao fato de viverem em tal modalidade de família.

De forma bastante consistente, tais pesquisas, em sua maioria enfocando famílias monoparentais com mãe lésbica ou biparentais de lésbicas e filho(s), contribuíram para atestar a "normalidade" destas famílias, como mostra o "Review", de

\footnotetext{
140 CADORET (2003) apud LIBSON, M. - "Yo opino... Construcciones Discursivas acerca de la Homoparentalidad”. In GROSSI, M. et al. (org.), op. cit., 2004.
} 
Patterson $^{141}$. A partir da utilização de diferentes metodologias, ainda que não especificadas por Garcia et. al. ${ }^{142}$, tais pesquisas mostraram não haver diferenças significativas entre crianças criadas em famílias homoparentais em relação àquelas advindas de famílias heteroparentais, em termos de presença de eventuais conflitos de personalidade ou de desenvolvimento, de orientação sexual e de adequação à escola e demais ambientes.

É inegável que, do ponto de vista estratégico, tais artigos e pesquisas certamente ajudaram na conquista dos direitos de gays e lésbicas em relação à maternidade, paternidade e guarda de crianças. Isso, no entanto, não pode ofuscar o fato de que certas contradições emergem destas conquistas, e merecem ser explicitadas.

Segundo Garcia et. al. ${ }^{143}$, a busca pelo reconhecimento legal da constituição de famílias homoparentais levanta, imediatamente, a questão do quanto esta busca, paradoxalmente, corresponde a uma reificação da família nuclear como modelo. $\mathrm{O}$ recurso a pesquisas que provariam a "normalidade" da família homoparental baseado na comparação com famílias heteroparentais envolve a defesa implícita de um modelo de família que é, ele mesmo, alvo de críticas.

Outro ponto relevante refere-se à possibilidade de, ao buscar o reconhecimento jurídico de suas famílias pela afirmação da "normalidade" das mesmas, gays e lésbicas acabarem por negar a própria homossexualidade. Muitas das pesquisas utilizadas como instrumentos para defender juridicamente as famílias homoparentais se baseiam na utilização da orientação sexual "heterossexual" das crianças como critério de adaptação positiva. Isso significa afirmar que as famílias homoparentais só seriam "normais" se as crianças nelas criadas não se tornassem mais facilmente homossexuais do que as criadas em famílias heteroparentais, o que mostra uma contradição evidente: para se afirmar o direito dos pais homossexuais, nega-se o direito do filho à orientação homossexual. A esse respeito, Roudinesco ${ }^{144}$ observa que, "ao buscarem convencer

\footnotetext{
${ }^{141}$ PATTERSOM (1995) apud GARCIA, M. R. V.; WOLF, A. G.; et. al. - "“Não Podemos Falhar”: a busca pela normalidade em famílias homoparentais". In GROSSI, M. et al. (org.), op. cit., 2004.

142 GARCIA, et. al. (2004), ibid.

143 GARCIA, et. al. (2004), ibid.

144 ROUDINESCO, E. (2003), op. cit., , p. 195.
} 
aqueles que os cercam de que seus filhos nunca se tornarão homossexuais, eles se arriscam a Ihes dar, de si próprios, uma imagem desastrosa"

Um outro aspecto ainda a ser ressaltado é que a defesa da "normalidade" de famílias homoparentais acaba por ajudar na consideração de que outras formas de sociabilidade, comuns em universos homoeróticos, são inadequadas para a criação de crianças. Os vínculos de amizade entre homossexuais masculinos aparecem, por exemplo, como um modelo alternativo em relação ao paradigma familiar no universo homoerótico brasileiro da segunda metade do século XX.

A busca pela aproximação com o modo tradicional de criação de filhos por parte de casais gays e lésbicas leva a um fortalecimento da ordem dominante na sociedade capitalista, que tem a família como modelo por excelência, em que os indivíduos são capturados espacial e identitariamente em organizações sociais mais definidas. Tal busca contribui para a reificação da estrutura familiar e das identidades de pais, mães e 'co-parents ${ }^{145}$. Não se pode esquecer, todavia, que os próprios homossexuais, em sua maioria, foram criados por pais heterossexuais e no mesmo modelo de família tradicional.

Alguns estudos realizados no Brasil a respeito de famílias homoparentais mostram que a luta pelo direito à parentalidade por parte de gays e lésbicas carrega muitas destas contradições. Souza ${ }^{146}$, por exemplo, ressalta que "a maternidade lésbica não se apresenta de forma absolutamente subversiva, pois não somente sustenta o discurso do 'instinto maternal' e da mulher enquanto reprodutora da vida como ainda mantém parcialmente a configuração familiar dentro dos limites da consaguinidade". No caso da cantora Cássia Eller, por exemplo, Tarnovski ${ }^{147}$ sugere que a relativa aceitação social do fato da companheira da cantora obter a guarda do filho biológico da cantora, após sua morte, se deu em grande parte em função dela ocupar um lugar (sociocultural) tradicionalmente feminino de mãe e dona-de-casa, o que provavelmente não ocorreria se a mesma questionasse a identidade tradicional de mulher "do lar".

\footnotetext{
145 Termo adotado por GARCIA et. al. (2004) para se referir ao parceiro ou à companheira do casal homossexual que divide o desempenho da parentalidade do(a) filho(a) com o pai ou a mãe (biológicos ou juridicamente reconhecidos), respectivamente.

${ }_{146}$ SOUZA (2005), p. 50, apud GARCIA et. al.(2004), op. cit.

147 TARNOVSKI (2002), apud GARCIA et. al.(2004), op. cit.
} 
Quando perguntado às respondentes, no exemplo de uma pesquisa realizada com mães heterossexuais sobre suas opiniões a respeito de duas mulheres que possuam um relacionamento afetivo poderem criar uma criança sozinhas, notou-se grande presença de homofobia: $44 \%$ discordam completamente; e, se comparada ao caso dos homens gays vivendo em união estável vindo a ter filhos (as), a homofobia é ainda maior: 56\% discordam completamente. Qualquer concordância ou discordância, em maior ou menor grau mostraram índices significativos de homofobia.

A homofobia não é um conceito de simples definição. Inicialmente empregado pelo psicólogo John Smith na década de setenta, pode-se dizer atualmente que a homofobia diz respeito a "qualquer sentimento de ódio, repulsa, aversão, descrédito ou desprezo à pessoa homossexual (ou àquelas que se presume serem) ou a tudo que faça referência à homossexualidade no outro ou em si próprio ${ }^{148 " . ~ T a n t o ~ q u a n t o ~ a ~}$ definição da homossexualidade, a definição e a manifestação da homofobia também variam conforme o contexto cultural. A homofobia pode se manifestar em qualquer tipo de forma específica de violência física, simbólica ou social contra os(as) homossexuais ${ }^{149}$. E mais, "juntamente com a xenofobia, o racismo ou o anti-semitismo, a homofobia é uma manifestação arbitrária que consiste em representar o outro como inferior ou anormal" (ERIBON $\left.{ }^{150}, 2003\right)$.

Estudiosos apontam que as bases da homofobia são o heterocentrismo, o heterossexismo e a heterossexualidade compulsória. O heterocentrismo refere-se a um modo de pensar, agir e sentir pautados na arbitrariedade do sexo biológico usado como premissa "verdadeira sobre os sexos", em que o eu posiciona a heterossexualidade como referência primeira dos desejos, ideais, princípios e valores, a qual produz , por sua vez, um sentimento de superioridade em relação a todas as outras manifestações da orientação e/ou identidade sexual. Dessa série deriva o heterossexismo, que

\footnotetext{
${ }^{148}$ Cf. TEIXEIRA FILHO, F. S.; TOLEDO, L. G. e GODINHO, P. H.. "A homofobia na representação de mães heterossexuais sobre a homoparentalidade". In GROSSI, M. et al. (org.) - Conjugalidades, Parentalidades e Identidades Lésbicas, Gays e Travestis. RJ: Garamond, 2004.

149 Ainda que o Brasil não faça parte do rol dos setenta países que, entre os 192 existentes no planeta, consideram a homossexualidade um crime, muitos estudos ainda demonstram uma considerável presença de homofobia na sociedade brasielira, bastando para tal as trágicas estatísticas colhidas apenas em notícias de jornais pelo Grupo Gay da Bahia (GGB) que apontam que no Brasil, só no ano de 2004, foram mortos mais de 150 homossexuais por motivos puramente homofóbicos (Mott, 2003).

${ }^{150}$ ERIBON (2003) apud TEIXEIRA FILHO et. al.(2004), op. cit.
} 
basicamente define a orientação heterossexual como "normal", "correta", "verdadeira" e, por isso, superior e compulsória a todas as outras orientações sexuais. Segundo Butler $^{151}$, a heterossexualidade compulsória concentra-se nos muitos tipos de intensa pressão que a sociedade exerce sobre as pessoas para garantir que a heterossexualidade se torne seu destino comum, ou seja, as pessoas são educadas para serem heterossexuais, e sempre se pressupõe que todos são ou deveriam ser heterossexuais.

Segundo Teixeira Filho et. al. ${ }^{152}$, as propriedades dessa "ditadura heterossexual" nas políticas de construção de gêneros e da cidadania são suficientes para que, no Brasil, o processo de legalização da união civil entre pessoas do mesmo sexo, a homoparentalidade e a adoção de crianças por homossexuais solteiros ou vivendo em parceria estável com alguém do mesmo sexo biológico dependa da jurisprudência e ainda estejam em situação de desigualdade em relação às pessoas heterossexuais. Por exemplo, não que haja uma proibição da adoção por homossexuais solteiros ou não, mas, em muitos casos, ela ainda é dificultada pelas instituições jurídicas e por juízes devido a homofobia em relação aos adotantes. Entretanto, parceiros homossexuais não podem legalmente adotar conjuntamente uma criança, e isso implica em grandes prejuízos para as partes envolvidas, tal qual demonstrado pela pesquisa de Figueiredo ${ }^{153}$, em que ficou percebido que, ainda que a sociedade brasileira esteja em processo de mudança quanto à homoparentalidade, ainda há muita resistência entre o "mitiê" jurídico e, especialmente, na categoria 'donas de casa' em relação à possibilidade de crianças virem a ser criadas por homossexuais.

Ainda em relação à pesquisa citada acima, a respeito dos preconceitos e crenças do senso comum em relação à homoparentalidade, evidenciou-se que a parentalidade lésbica é mais aceita que a parentalidade gay. Isso talvez possa ser explicado a partir dos estudos de Badinter ${ }^{154}$ sobre "o mito do amor materno" como sustentáculo do heterossexismo, independentemente da orientação sexual da mulher. Outros estudos

\footnotetext{
151 BUTLER, J. - Problemas de gênero - feminismo e subversão da identidade. RJ: Civilização Brasileira, 2003.

152 TEIXEIRA FILHO et. al., op. cit., 2004.

153 FIGUEIREDO (2001) apud GARCIA et. al., op. cit., 2004.

154 BADINTER, E. - Um amor conquistado - o mito do amor materno. RJ: Nova Fronteira, 1985.
} 
mais atuais, tais como o trabalho de Uziel ${ }^{155}$, também corroboram estas evidências. $A$ pesquisadora, na análise de uma tabela com os resumos dos oito processos de adoção estudados, encontrou que, em quatro deles, foi revelada a orientação sexual dos requerentes à adoção (três homens e uma mulher). O Ministério Público deu parecer desfavorável aos três requerentes gays, e favorável à requerente lésbica.

Nas correlações dos dados (entre histórico familiar e tipo de formação pregressa das mães que poderiam ou não contribuir para explicar os fundamentos da homofobia e preconceito contra a homoparentalidade), o que Teixeira Filho et. al. ${ }^{156}$ encontraram, de fato, foi a seguinte "equação": formação religiosa fundamentalista + histórico familiar conservador + desinformação acerca da homossexualidade + homofobia, geram um forte preconceito em relação à homoparentalidade (principalmente aquela exercida por homens gays).

Os dados também apontaram que a homofobia em torno da homoparentalidade se mascara em opiniões relativas ao bem estar geral da criança. Isto é, em casos em que a homossexualidade do casal não foi rejeitada per se, encontrou-se o temor de que a criança venha a ser rejeitada socialmente por ter pais ou mães homossexuais (82\% das participantes concordam que as crianças criadas por pais ou mães homossexuais estarão sujeitas à hostilidade e serão rejeitadas pelas pessoas), ou possam apresentar um desenvolvimento prejudicado pela falta da figura do pai ou da mãe na família (74\% concordam que crianças precisam de um pai e uma mãe para terem os modelos masculino e feminino apropriados). Isto indica que a questão levada em conta é também a homosexualidade dos pais. Esta análise sugere que a homoparentalidade é danosa à criança, podendo gerar-Ihe prejuízos sociais, como discriminação, rejeição, hostilidade e desenvolvimento insatisfatório devido à falta de modelos sociais de masculino e feminino ditos apropriados.

A fobia à homossexualidade aliada à relação desigual existente entre o homem e a mulher sustentada no mundo heterossexual apresenta-se ainda no fato das participantes terem rejeitado a homoparentalidade gay, pois que esta representaria a

\footnotetext{
${ }^{155}$ UZIEL (2002) apud TEIXEIRA FILHO et. al., op. cit., 2004.

156 TEIXEIRA FILHO et. al., op. cit., 2004.
} 
invasão do homem naquilo que é o seu território estabelecido: a educação das crianças.

Teixeira Filho et. al. ${ }^{157}$ apontam ainda que inúmeras outras pesquisas demonstram que não há prejuízo algum para as crianças que são criadas por pessoas homossexuais. Em especial, destacam o estudo longitudinal realizado junto aos filhos e filhas de mulheres lésbicas no qual conclui que os "jovens adultos criados por uma mãe lésbica não estavam mais suscetíveis que aqueles que teriam sido criados em contextos heterossexuais de terem que procurar uma ajuda profissional para suas dificuldades psicológicas". Afirmam criticamente que em nome de uma "tal" "ordem simbólica" e da heterossexualdiade compulsória, o sistema judiciário, as ciências "psi" e a sociedade em geral, impedem que muitas crianças em situação de risco social e/ou abandono tenham acesso ao seu direito de cidadania tal qual promulgado no ECA: o direito à infância. Inflancionados pelo preconceito, juristas, profissionais da saúde, assistência social e psicologia fazem com que inúmeras crianças brasileiras paguem o juros desta dívida homofóbica.

As bases que sustentam esses eixos, segundo Teixeira e Filho et. al. ${ }^{158}$, ainda é o fato de que nossa sociedade está organizada a partir da visão e da divisão do mundo social, que repousa sobre a ilusão teológica segundo a qual o homem seria feito para a mulher e, sobretudo, a mulher para o homem, produzindo a convicção íntima de que esse seria o modelo necessário e o horizonte último de toda a sociedade humana.(BOURDIEUX ${ }^{159}$, 2002)

No tocante ao campo político, Mello ${ }^{160}$ afirma, quanto aos posicionamentos expressos pelos parlamentares nos debates na Câmara dos Deputados sobre o Projeto de Lei no 1151/95, que as resistências ao reconhecimento de direitos parentais a lésbicas e gays, especialmente no âmbito do casal conjugal, também se fizeram presentes, inclusive entre alguns daqueles que defenderam a necessidade de amparo legal à conjugalidade homossexual. Geralmente tal resistência fundava-se no

\footnotetext{
157 ld., ibid.

158 Id., ibid.

159 BOURDIEUX (2002) apud TEIXEIRA FILHO et. al., op. cit., 2004.

160 MELLO, op. cit., 2005.
} 
entendimento de que a homossexualidade seria um mal que por si só e que implicaria a negação da competência moral de lésbicas e gays para socializar crianças, além da compreensão de que pais homossexuais colocariam seus filhos sob o risco de também se tornarem homossexuais.

O preconceito a que estas crianças estariam sujeitas em função da orientação sexual de seus pais foi outro argumento apresentado, sendo o único prevalecente quando a resistência ao direito à socialização de crianças foi manifestada por parlamentares favoráveis ao Projeto. Note-se, porém, que muitos parlamentares, especialmente entre os que defendiam a aprovação do Projeto, sumariamente não se manifestaram acerca desta questão, talvez por entenderem que a mesma não era objeto de discussão, uma vez não contemplada na proposição. Na versão original do Projeto de Lei $\mathrm{n}^{0}$ 1151/95, não há qualquer referência - seja proibindo, seja autorizando - à adoção de crianças por casais homossexuais. Já no Substitutivo proposto pelo Relator, Deputado Roberto Jefferson, e aprovado pela Comissão Especial, fica estabelecido que, no contrato de parceria civil registrada entre pessoas do mesmo sexo, não pode constar quaisquer disposições sobre adoção, tutela ou guarda de crianças ou adolescentes em conjunto, mesmo que sejam filhos de um dos parceiros.

Por outro lado, vê-se que todos os representantes da sociedade civil que atuaram como expositores em audiências públicas da Comissão Especial defenderam a aprovação do Projeto como uma decorrência da necessidade de garantia dos direitos humanos e de cidadania dos homossexuais, geralmente também se referindo ao fato de que a ciência não reconhece a homossexualidade como doença ou desvio. $\mathrm{O}$ expositor originário da Igreja Católica foi o único a privilegiar a ótica religiosa em seu pronunciamento, mesmo assim apresentando argumentos favoráveis e contrários ao amparo legal à conjugalidade homossexual, desconsiderando, inclusive, o posicionamento oficial da CNBB. Prevaleceu entre os expositores o não posicionamento expresso acerca da natureza dos vínculos que unem homossexuais em uma relação estável, tratando-se a questão na perspectiva da ausência de fundamentos médicos, psicológicos, jurídicos e sociais que justifiquem o não reconhecimento da legitimidade das uniões afetivo-sexuais entre pessoas do mesmo sexo. 
Assim, seja por meio da definição explícita das uniões homossexuais como entidades familiares, fundadas no amor conjugal, seja pela analogia entre união civil homossexual e união estável heterossexual, seja pelo entendimento de que aos parceiros de uniões homossexuais devem ser assegurados direitos patrimoniais e previdenciários - os quais são constitutivos da idéia de família também no contexto heterossexual - todos os expositores propuseram, direta ou indiretamente, a ruptura da norma heterocêntrica e o conseqüente alargamento do sentido de família, de forma a incorporar, no leque das relações socialmente definidas como conjugais, as uniões homossexuais. Nota-se que as discussões acerca do direito de lésbicas e gays à parentalidade foram absolutamente secundárias - se não ausentes - no contexto dos pronunciamentos dos expositores, havendo apenas um único que se posicionou radicalmente contra.

Os direitos parentais de lésbicas e gays, no âmbito da monoparentalidade ou do casal conjugal, foram defendidos a partir do argumento de que a orientação sexual homossexual não é incompatível com o exercício da paternidade e da maternidade, sendo freqüentes as alusões a estudos científicos que apontam a não influência da orientação sexual dos pais na conformação da orientação sexual dos filhos (vide citação acima de Teixeira Filho). Nega-se, por outro lado, a legitimidade do argumento segundo o qual homossexuais não devem assumir funções parentais para proteger seus potenciais filhos do preconceito e da discriminação, sendo a superação destes entendida como o caminho para a construção de uma sociedade que respeite tanto adultos homossexuais quanto seus filhos, biológicos ou adotivos, sejam eles homo ou heterossexuais.

\subsection{1: O Debate no Campo Jurídico.}

A legislação brasileira não incide da mesma maneira sobre as diferentes possibilidades de existência de famílias homoparentais. A co-parentalidade, por exemplo, é uma das formas possíveis de família homoparental sobre a qual o direito não tem nenhuma ingerência na construção. O nosso Código Civil tampouco prevê a 
complexidade de alianças e filiações decorrentes da co-parentalidade homossexual. Dessa forma, não pode garantir à criança nem a estabilidade nem a memória de seus vínculos parentais, pois, ao reconhecer a existência legal de apenas um pai e uma mãe, deixa fora da proteção do Estado os outros participantes dessa nova configuração, juntamente com os direitos e deveres que lhes são inerentes.

Nos casos de co-parentalidade, a criação do filho se dá de forma conjunta, pelo contrato entre duas pessoas (ou dois casais) de sexo oposto, que não mantêm entre si relação de conjugalidade. Essa modalidade inscreve a concepção num contexto heterossexual e a criação em contexto deliberadamente homossexual. Assim, os coparentes asseguram à criança, pelo menos teoricamente, o conhecimento das origens biológicas e afetivas, mas não garantem a proteção legal das relações derivadas delas. O recurso ao uso de novas tecnologias reprodutivas também não está regulamentado pelo Código Civil brasileiro. Segundo Brauner ${ }^{161}$, a única normatização existente é uma resolução do Conselho Federal de Medicina, o que deixa a cargo das opiniões pessoais e posições ideológicas dos médicos o acesso ou não dessas pessoas homossexuais às novas tecnologias.

Nessas duas situações os problemas legais acontecem depois do nascimento do filho e são relativos aos direitos e deveres dos parceiros/as dos pais/mães biológicos, que ainda não encontraram lugar nem social nem legalmente reconhecido.

Nos casos em que o contexto familiar homossexual é posterior a uma relação heterossexual desfeita, o problema legal que poderá surgir será relativo ao uso da homossexualidade de um dos pais como justificativa para impedimento do exercício do seu direito de parentalidade como guarda, visita, pernoite, férias, etc. Em outros casos, pode haver uma exigência por parte do pai/mãe heterossexual de não-convivência da criança com o novo parceiro/a do pai/mãe homossexual, sob alegação de ser necessário proteger a criança do conhecimento desse tipo de relacionamento. Nessas situações, o impedimento constitucional de discriminação, por qualquer razão, deveria ser suficiente para evitar que os direitos parentais das pessoas homossexuais sejam desrespeitados. Entretanto, as pesquisas mostram que uma das grandes preocupações das mães lésbicas é, justamente, perder a guarda dos seus filhos devido a tal tipo de

${ }^{161}$ BRAUNER (2003) apud ZAMBRANO, op. cit., 2006. 
situação. Quando isso acontece, a justificativa apresentada na sentença costuma ser a defesa do melhor interesse da criança, ao ser considerada a homossexualidade do pai/mãe um fator de prejuízo para o bom desenvolvimento do filho (JULIEN; DUBÉ; GAGNON $^{162}$, 1994).

Quando a escolha é pela adoção, os diferentes obstáculos jurídicos à constituição de uma família adotiva homoparental decorrem, de um lado, da impossibilidade de desvincular os aspectos biológicos, sociais e jurídicos da filiação e, de outro, da norma da "diferença dos sexos". A adoção legal é a situação na qual o poder judiciário é sempre chamado a se manifestar e, como tem por finalidade dar uma família a uma criança, a intenção é criar uma filiação o mais próximo possível da biológica, mesmo que a adoção seja o exemplo típico de filiação instituída pelo direito e não pela natureza (GROSS $\left.{ }^{163}, 2003\right)$. Como na homoparentalidade por adoção essa ficção jurídica não pode ser mantida, fica dificultada a adoção pelos casais homossexuais, embora a lei não traga impedimento à adoção por casais homossexuais.

Dias $^{164}$, desembargadora do Estado do Rio Grande do Sul, autora da área do Direito e especialista nas questões dos direitos homoparentais, considera que "a definição da paternidade está condicionada à identificação da posse do estado de filho, reconhecida como a relação afetiva, íntima e duradoura, em que uma criança é tratada como filho, por quem cumpre todos os deveres inerentes ao poder familiar: cria, ama, educa e protege". Assim, para essa autora, o que interessa aos operadores do direito nas questões de paternidade é que ela seja "reconhecida pelo vínculo de afetividade, fazendo nascer a filiação socioafetiva" (DIAS $\left.{ }^{165}, 2003\right)$.

Desenvolvendo argumentos que buscam demonstrar a legitimidade da paternidade homossexual, a autora serve-se de argumentos que desnaturalizam o conceito tradicional de família, de modo a ampliá-lo, para que abarque a realidade das famílias homoparentais.

\footnotetext{
162 JULIEN; DUBÉ; GAGNON ${ }^{162},(1994)$ apud ZAMBRANO, op. cit., 2006.

163 GROSS (2003) apud ZAMBRANO, op. cit., 2006.

164 DIAS, Maria Berenice. - "A paternidade homoparental". In GROENINGA, G. e CUNHA PEREIRA, R. (orgs.). - Direito de Família e Psicanálise - rumo a uma nova epistemologia. RJ: Imago, 2003, pp. 269/275.

${ }^{165}$ DIAS, M. B. (2003), ibidem.
} 
Para o estabelecimento do vínculo de parentalidade, basta que se identifique quem desfruta da condição de pai, quem o filho considera seu pai, sem perquirir a realidade biológica, presumida, legal ou genética (...) pois família, como afirma Lacan, não é um grupo natural, mas um grupo cultural, e não se constitui apenas por um homem, mulher e filhos, conforme bem esclarece Rodrigo da Cunha Pereira: a família é uma estruturação psíquica, onde cada um de seus membros ocupa um lugar, desempenha uma função, sem estarem necessariamente ligados biologicamente ...

Não se pode fechar os olhos e tentar acreditar que as famílias homoparentais, por não disporem de capacidade reprodutiva, simplesmente não possuem filhos. Se está à frente de uma realidade cada vez mais presente: crianças e adolescentes vivem em lares homossexuais (DIAS $\left.{ }^{166}, 2003\right)$.

Continua ainda defendendo a necessidade de uma jurisprudência em relação às famílias homoparentais, no sentido de reconhecê-las, considerando os vínculos afetivos estabelecidos entre os dois parceiros que criam e cuidam da criança, como condição necessária para a existência de familiaridade .

A maior visibilidade e melhor aceitabilidade das famílias homoafetivas torna impositivo o estabelecimento do vínculo jurídico paterno-filial com ambos os genitores, ainda que sejam dois pais ou duas mães. Vetar a possibilidade de juridicizar a realidade só traz prejuízo ao filho, que não terá qualquer direito com relação a quem exerce o poder familiar, isto é, desempenha a função de pai ou de mãe. Presentes todos os requisitos para o reconhecimento de uma filiação socioafetiva, negar sua presença é deixar a realidade ser encoberta pelo véu do preconceito. (...) Existindo um núcleo familiar, estando presente o elo de afetividade a envolver pais e filhos, a identificação da união estável do casal torna imperioso o reconhecimento da dupla paternidade. Para assegurar a proteção do filho, os dois pais precisam assumir os encargos do poder familiar. (DIAS ${ }^{167}, 2003$ )

\footnotetext{
166 Idem, ibidem.
}

${ }^{167}$ Idem, ibidem. 
Confirma-se, assim, o exposto mais acima de que o alvo maior em relação a possíveis mudanças de atitudes dos operadores do direito quanto à homoparentalidade está na defesa dos interesses da criança e dos supostos benefícios a ela.

Finalizando, Dias também aponta criticamente para as falsas crenças culturais e seus respectivos receios em relação à homoparentalidade e para a existência de homofobia em casos de resistência à regulamentação da questão, referindo-se a estudos (acadêmicos e científicos) que desmitificam tais crenças.

A enorme resistência em aceitar a homoparentalidade decorre da falsa idéia de que são relações promíscuas, não oferecendo um ambiente saudável para o bom desenvolvimento de uma criança. Também é alegado que a falta de referências comportamentais pode acarretar seqüelas de ordem psicológica e dificuldades na identificação sexual do filho. Mas estudos realizados a longo tempo mostram que essas crenças são falsas. O acompanhamento de famílias homoafetivas com prole não registra a presença de dano sequer potencial no desenvolvimento, inserção social e sadio estabelecimento de vínculos afetivos. Ora, se esses dados dispõem de confiabilidade, a insistência em rejeitar a regulamentação de tais situações só tem como justificativa uma indisfarçável postura homofóbica (DIAS ${ }^{168}, 2003$ ).

Confirma-se, assim, como exposto mais acima e afirmado por diversos autores que a estratégia que tende a ser utilizada pelos ativistas do movimento homossexual, bem como por profissionais e intelectuais do campo político e jurídico para a conquista dos direitos homoparentais está muito mais voltada para uma ampliação do conceito normativo de família, de modo a abarcar a realidade homoparental, transformando o que é tido como 'estranho' ou 'outro' em familiar, em conhecido, o 'nós' da identidade e da igualdade que faz laço social.

\footnotetext{
168 Idem, ibidem.
} 


\section{5: FUNÇÕES PARENTAIS EM PSICANÁLISE: A DIFERENÇA ENTRE PAPÉIS E FUNÇÕES MATERNA E PATERNA.}

Antes de adentrar as funções e papéis parentais nos casais homoparentais, será abordada, neste capítulo, a distinção entre os conceitos de função materna e função paterna e as figuras parentais de pai ou mãe, segundo o referencial psicanalítico, que postula que tais funções estão determinadas pela linguagem e cultura, em sobreposição aos determinantes biológicos.

No senso comum, de modo geral, as figuras parentais estão coladas ao sexo biológico daquele que a exerce. Assim, a mãe é aquela que gera e dá à luz, portanto, sempre uma mulher, e o pai é o parceiro da mãe, aquele que a fecundou, que a ajuda nos cuidados e, principalmente, é o responsável pela educação dos filhos, no que diz respeito ao ensinamento das regras e normas sociais, ou seja, no processo de disciplinarização.

Ver-se-á, a seguir, a distinção que a Psicanálise coloca entre essas ideias que fazem parte do Imaginário Sociocultural e as condições estruturais e psíquicas necessárias à constituição do sujeito.

\section{1: A FUNÇÃO MATERNA E A MÃE-MULHER.}

Ao se perguntar qual a função de uma mãe, obtêm-se, em geral, respostas como: dar à luz, alimentar, cuidar, educar, entre outras. Trata-se do papel da mãe, que está determinado socioculturalmente. Segundo os arranjos culturais patriarcais, a mãe é a exclusiva responsável pela educação dos filhos, além de sua exclusiva guardiã, tornando-se, por conseguinte, a "todo-provedora".

Antes de considerar o papel dos pais, torna-se necessário distinguir entre os pais reais e os pais entendidos como funções que se exercem.

Segundo a perspectiva psicanalítica, pai, mãe e filho são pensados antes como funções do que como pessoas. Dessa forma, a função materna é aquela "ligada ao 
desejo, à idéia de completude e de satisfação, à idéia de totalidade, à vida e à morte" (BRAUER $^{169}$,1993). O desejo da mãe pelo filho é sustentado pela fantasia de que este Ihe fosse completá-la e vice-versa, anulando qualquer possibilidade de falta entre os dois seres, numa experiência de satisfação e plenitude absolutas. Em Psicanálise, o desejo, que é da ordem do inconsciente, diferentemente da vontade consciente, não é o equivalente exato do amor materno, mas passa necessariamente por este, ou seja, o amor materno está atravessado pelo desejo da mãe pela criança.

Nessa mesma perspectiva, Faria ${ }^{170}$, psicanalista de orientação lacaniana, enfatiza que:

Ao contrário do que se poderia pensar, o exercício da função materna não depende, necessariamente, da presença da mãe biológica. A mãe biológica é única e, como tal, insubstituível, mas a função pode ser exercida através de outra pessoa. Ainda que a coincidência entre a mãe biológica e função materna seja o mais comum, a mãe que gera não tem que ser necessariamente aquela que exerce essa função. Se na ausência da mãe biológica houver um substituto, a função se preserva.

Dessa forma, a articulação fixa entre a genitora e a mãe que exerce a função materna nem sempre necessita existir para que essa função primordial à constituição psíquica da criança se preserve. E vale ressaltar que o substituto da mãe biológica pode ser de qualquer sexo ou gênero e de qualquer orientação de desejo sexual, ou escolha de objeto, desde que possua essa relação de desejo com a criança, investindoa libidinalmente, traduzindo as necessidades do pequeno infante em demandas, relação esta que criará a ilusão de completude, laço libidinal que, em outro momento, carecerá da interdição de uma outra função, a paterna, como limitadora dessa relação, através da entrada em cena de um terceiro nessa relação dual, propiciando o desenvolvimento psíquico do sujeito.

169 BRAUER, J. F.(1993) apud PAIVA, L. D. - Adoção. Significados e possibilidades. SP: Casa do Psicólogo, 2004, p.86.

${ }^{170}$ FARIA, Michele Roman apud PAIVA, L. D., op. cit., 2004, p.86. 
Tal possibilidade de substituição da mãe biológica, no entanto não nega a importância da função materna, visto que, segundo Faria ${ }^{171}$, as crianças que, por abandono, não possuem outra figura de referência que possa substituir a mãe biológica acabam sofrendo, em geral, graves conseqüências em seu desenvolvimento afetivo e até em sua sobrevivência. Nas palavras da autora: "é fácil perceber como a falha diz respeito não tanto à presença da mãe biológica junto à criança, mas à ausência de uma função operante" (FARIA, 1998 ${ }^{172}$ ).

Colette Soler ${ }^{173}$, iminente psicanalista francesa de orientação lacaniana, reiterando a diferença entre a pessoa da mãe e a função materna, afirma:

Da mãe, parece que também é possível prescindirmos, ou queremos fazê-lo, ou até devemos fazê-lo, (...), mas sob a condição de que primeiro ela o tenha servido... pelo menos para a produção do corpo. (...) A mãe, como genitora, não é um semblante (...). A função de maternação é substituível. As antigas práticas das amas-secas, assim como as práticas mais atuais da adoção, dão testemunho disso.

Com efeito, percebe-se que, para a Psicanálise, é a função de um outro, dito por Lacan como grande Outro primordial, a que opera na base mais fundamental da constituição do sujeito psíquico, formando uma matriz simbólica primordial para o sujeito. Função esta que, convém repetir, pode ser exercida por qualquer pessoa, independente de sexo ou de sua orientação do desejo afetivo-sexual, ou seja, de sua escolha objetal, desde que faça a função de tomar a criança e, principalmente, de colocar-se a ela como lugar e objeto de satisfação libidinal, capaz de traduzir as necessidades caóticas da criança em demandas dirigidas a um Outro capaz de atendêlas.

Segundo Soler ${ }^{174}$, "Freud construiu uma estrutura que distribuía as funções: de um lado, um objeto de satisfação primária, de outro, uma função de limite", confrontando-se, no romance edípico da criança, de um lado a mãe-objeto - seja de

\footnotetext{
${ }^{171}$ FARIA, M. R.; apud id. ibid., p. 87.

172 FARIA, M. R.; apud id. ibid., p. 87.

173 SOLER, Colette. - O que Lacan dizia das mulheres. RJ: Jorge Zahar, 2005, p.87.

${ }^{174}$ Id., ibid., p. 88.
} 
amor, de desejo ou de gozo -, objeto a ser perdido, e por outro, o pai freudiano, portador da proibição do acesso a esse objeto, a essa mãe. Tal seria, enquanto personagens do mito, segundo Lacan da década de 50, enquanto lugares e funções simbólicas e imaginárias, a estrutura familiar necessária para a constituição do sujeito desejante, tal como visto no capítulo sobre o complexo de Édipo.

"No começo há o gozo e o desejo da mãe". Da relação da criança com a mãe (ou seu substituto), "de onde as palavras e os corpos se encontraram na vida do sujeito, ficam marcas" (ZALCBERG, 2008) ${ }^{175}$. E tais marcas significantes, as palavras do Outro materno que incidem no desenvolvimento erótico da criança, através da contingência do encontro inicial corpo a corpo, deixam traços na carne.

É este pedaço de real parasita do gozo ao redor do qual gira uma vida, ao redor do que bordeja o inconsciente (...) São esses traços (...) que a limitação do gozo - de outra forma sem limites, da Coisa primordial, isto é, da mãe - encontrará caso possa vir a fazer um furo no real indiferenciado que o 'infans' vive, permitindo, assim, o advento do sujeito. (...) Trata-se de uma limitação aportada pela função do pai: interdição do incesto e estabelecimento da lei simbólica que resultam da implementação dessa função paterna ${ }^{176}$.

A partir do conceito de função materna e das marcas significantes que restam da relação de cada um com a mãe, é possível afirmar-se com Soler ${ }^{177}$ que cada um traz "no mais íntimo de si a marca do "Outro primordial", ou seja, aquele que fez a função materna para o sujeito. "Nesse aspecto, a psicanálise está em sintonia com o declínio do pai na cultura, pelo menos por não ter parado de enfatizar cada vez mais o papel da mãe".

E o que dizer da mãe, do seu papel atual junto ao filho, tendo em vista as mudanças da cultura? A figura da mãe surge atrelada às mudanças do papel e lugar da

\footnotetext{
${ }^{175}$ ZALCBERG, M. "No começo há o gozo e o desejo da mãe". In: ALBERTI, S. (org.) - A Sexualidade na aurora do século XXI. RJ: Cia. de Freud: CAPES, 2008. Pp. $161-177$.

176 Idem, ibidem.

177 SOLER, op. cit., p. 88.
} 
mulher na cultura. É a mulher que teve que se dividir em seus papéis de mulher (desejante e desejada), de trabalhadora e de mãe. Este último, conforme se verifica nos discursos correntes, não passou por muita transformação quanto à sua imagem e ao lugar e que esse personagem ocupa no imaginário social. Ou seja, a mãe, a "boa" mãe, continua a ser aquela - ou, por que não?, aquele - que cuida, educa e ama o(s) filho(s), permanecendo com estes no lar, na maior parte do tempo.

Nas palavras de Soler:

“(...) há um discurso prévio sobre a mãe que faz dela o objeto vital por excelência: o pólo das primeiras efervescências sensuais, a figura que cativa a nostalgia essencial do ser falante, o próprio símbolo do amor. (...) Imperiosa, possessiva, obscena ou, ao contrário, indiferente, fria e mortífera, presente demais ou ausente demais, atenta demais ou distraída demais, quer cubra de mimos, quer prive, quer se preocupe, quer se mostre negligente, por suas recusas ou por suas dádivas, ela é, para o sujeito, uma imagem de suas primeiras angústias, lugar de um enigma insondável e de uma ameaça obscura". (SOLER ${ }^{178}$, 2005: 90)

Na experiência de análise, por outro lado, a mãe dirá respeito a outra coisa, isto é, à emergência de imagens rememoradas pelo sujeito e às marcas que ele recebe ou recebeu desse Outro. Ainda citando Soler:

"Uma coisa é fato: da mãe de quem se fala à mãe que fala, a distância é grande. A primeira é objeto, vista pelo prisma da fantasia do falante. A segunda é sujeito, eventualmente analisanda e, como tal, às voltas com a divisão do falasser (parlêtre). O problema todo, por conseguinte, é apreender, em cada caso, "por que caminho passam as fantasias do sujeito, para ir da mãe ao filho", porque não se pode duvidar de que as fantasias que ela suscita devem algo a sua própria subjetividade, a sua falta e a sua maneira de obturá-la ${ }^{179 " .}$.

\footnotetext{
${ }^{178}$ SOLER, op. cit., p. 90.
}

${ }^{179}$ SOLER, op. cit., p. 91. 
Nos primórdios da constituição do sujeito, o corpo do infans está implicado, com certeza, nas marcas simbólicas que a função materna lhe inscreve. Ela já se constitui um sujeito no discurso do casal parental.

A criança por nascer já constitui um sujeito no dito dos pais e quando surge no mundo é como corpo, no sentido do organismo sexuado. Organismo que é preciso fazer viver, mas sobretudo, organismo a ser...civilizado e subjugado aos usos prescritos. A mãe, ou seu substituto, não deixa de ter que pôr a mão na massa: ao emprestar sua voz aos primeiros imperativos da regulação e contenção, ela é, nesse aspecto, a primeira mediação do que convém realmente chamarmos de... a polícia do corpo. Esta não pode passar simplesmente pelo silêncio dos hábitos regularizados, embora suas marcas não deixem de ter influência. É preciso haver a linguagem em que a demanda se articula, e que é a única a permitir que esse corpo seja "corporalizado de maneira significante." (SOLER $\left.{ }^{180}, 2005: 92\right)$

$\operatorname{Lacan}^{181}$, no seminário 11 , vai tratar da constituição do sujeito para além da estrutura quaternária pai-mãe-criança-falo de sua teoria nos anos 50 , mas em termos das operações de alienação e separação, pelas quais o sujeito passa para se constituir. A alienação, primeiro momento da constituição subjetiva, refere-se à relação do sujeito com o Outro primordial, ou seja, com a função materna, o Outro matriz simbólica e fonte dos significantes que marcarão o corpo e o gozo da criança. É a partir da alienação do sujeito aos ditos da mãe, ao campo do Outro, que o eu, enquanto imagem alienada do sujeito, advém. Sem a entrada na operação da alienação, a clínica nos mostra que o infans acaba por fixar-se numa posição autista.

Sobre a alienação, Soler afirma:

"a alienação inerente ao amor é elevada pela relação mãe-filho a uma potência superior, na medida em que, no começo, o recém-nascido não é um sujeito, mas um objeto. Objeto real nas mãos da mãe, que, muito além do que é exigido pelos cuidados, pode servir-se dele como de uma propriedade, uma boneca erótica com que gozar e a que deve fazer gozar ${ }^{182 "}$.

\footnotetext{
${ }^{180}$ SOLER, op. cit., p. 92.

${ }^{181}$ LACAN, J. O Seminário, livro 11 - Os quatro conceitos fundamentais da psicanálise. (1964). 2ª ed. RJ: Zahar, 1998.

${ }^{182}$ SOLER, op. cit., p. 93.
} 
A posição inicial da criança em relação à mãe, numa relação alienada, é de objeto de gozo dessa última. Conforme as palavras de Soler:

Conquistador da presença e do amor maternos, em função de sua própria demanda, o filho inicialmente se oferece, nos engodos da sedução, para realizar o que os ditos e condutas da mãe (ou do Outro primordial) deixam entrever do objeto de seu desejo. Nesse processo, a mãe é elevada à condição de potência simbólica, detentora dos poderes da fala e, por conseguinte, dos poderes originários das primeiras frases. "O dito primeiro decreta, legifera, sentencia, é oráculo, confere ao outro real sua obscura autoridade. Deixa uma marca na memórias, na qual reencontramos a voz, às vezes devastadora e persecutória, de suas palavras, seus imperativos e seus comentários... inesquecíveis ${ }^{183}$.

Vê-se a importância ressaltada dos primeiros ditos e atitudes maternais na relação com a criança. Cada vez mais, no entanto, é possível perceber-se a separação que há entre a mulher enquanto mãe e a função que de fato opera no sujeito para a sua constituição. Nos dizeres de Soler:

Entre a mãe e a mulher existe um hiato, aliás muito sensível na experiência. Às vezes, o filho fálico é passível de tamponar, de silenciar a exigência feminina, como vemos nos casos em que essa maternidade modifica radicalmente a posição erótica da mãe. No essencial, porém, o dom do filho só raramente permite fechar a questão do desejo. O filho, como resto da relação sexual, realmente pode obturar em parte a falta fálica na mulher, mas não é a causa do desejo feminino que está em jogo no corpo a corpo sexual184.

Dessa forma, assim como a mulher não é a mãe, pode-se, de forma invertida, dizer que a mãe não é necessariamente uma mulher.

\footnotetext{
183 Id. Ibid., p. 94.

184 Id. Ibid., p. 35.
} 
Assim, se a função materna, isto é, esta função de investimento libidinal e simbólico, de humanização, é tão imprescindível, além dos cuidados básicos e alimentação também importantes, podemos pensar que na situação de um casal homossexual masculino, será necessário que ao menos um dos membros do casal encarregue-se, por exemplo, não só dos cuidados básicos de um recém-nascido, mas que também encarne o operador da função materna, de Outro primordial. Em casos de crianças maiores, e que não apresentam grave psicopatologia, pode-se pensar que essa função deva ter sido efetuada por algum outro sujeito, antes do novo casal que irá assumir as funções parentais com essa criança.

De mesmo modo, na situação de uma casal de mulheres que criam uma criança, ao menos uma dever encarregar-se dos cuidados e da função materna, o que, supõese, poderá se dar de modo mais fácil, menos por algo da ordem de instinto materno, porém levando em consideração o lugar histórico-cultural tradicional da mãe atribuído à mulher.

A respeito das possíveis falhas na função materna, sabe-se da sua ausência de operação no sujeito, nos casos de autismo e da falha no processo de separação e fixação na alienação, em casos de psicose infantil. As falhas de separação, porém, podem ocorrer mesmo nos casos de neurose. Segundo Soler:

Não é a falta de amor, mas o excesso de amor, que pode ser prejudicial aqui e que clama por um efeito de separação necessário. Foi por isso que Lacan enfatizou o desejo da mãe. Este deve ser entendido como o desejo da mulher na mãe, desejo adequado para limitar a paixão materna, para torná-la não-toda mãe, ou, em outras palavras, não-toda para seu filho e até não-toda para a série de filhos, os rivais fraternos. Isso já estava implícito na escrita da metáfora paterna, pois a operação que coloca o significante do pai no lugar do significante da mãe tem por resultado especificar a falta materna como falta fálica e instituir o pai como parceiro fora da série ${ }^{185}$.

Sobre as condições ideais para a função materna, Soler afirma:

\footnotetext{
185 Id. Ibid., p. 95.
} 
A mãe não é toda para seu filho porque sua aspiração fálica divide-se entre o homem e o filho, e é bom que seja assim, porque é o desejo da mulher, mais geralmente um desejo outro mantido fora das gratificações da maternidade, que introduz a criança, por meio da angústia de castração, numa dialética de identificações contraditórias pela qual ela poderá soltar-se da posição passiva de objeto da mãe e, no fim, assumir seu próprio sexo ${ }^{186}$. (grifo meu).

Como se vê, ao contrário do que comumente se pensa ser o ideal, é a falta da mãe, ou seja, o fato de que a mãe - ou seu substituto - possa desejar para além do filho e permitir que essa falta, esse outro desejo para além dele se apresente, que irá possibilitar a separação do sujeito do desejo materno. Continuando com Soler:

O desejo propriamente feminino deixa a mãe ausente para seu filho, como eu disse, mas, para o filho, a diferença será grande, conforme essa ausência se decifre na ordem fálica ou, ao contrário, ultrapasse-a obscuramente. (...) Num dos pólos da nocividade materna evoquei a mãe totalmente ocupada com o filho. No pólo oposto, conviria situar a mãe nada ocupada com o filho, e confrontar o filho refém da primeira com o filho abandonado da segunda, sem recursos diante do poder de um silêncio insondável, que equivale a um ponto de foraclusão. Isso não implica, em absoluto, o abandono pela mãe, ou talvez devêssemos falar de um abandono subjetivo, por falta do único significante que equivale ao significante do gozo, ou seja, o Falo ${ }^{187}$.

Ao que se refere à relação não-patológica da criança com a mãe, ou seja, a que possibilita à criança seu desenvolvimento e constituição de sua própria subjetividade, conclui-se que, para a criança, a dedicação materna tem um valor tanto maior quanto mais a mãe não é toda sua, e "quanto mais não está toda num alhures insondável: mas é preciso que seu amor de mulher esteja referido a um nome. Só há amor por um nome, dizia Lacan: no caso, o nome de um homem, que pode ser qualquer um, mas que, pelo simples fato de ser nomeável, cria um limite para a metonímia do falo, assim

\footnotetext{
${ }^{186}$ Id. Ibid., p. 95.

187 ld. Ibid., p. 96.
} 
como para a opacidade do Outro absoluto. Só mediante essa condição é que a criança poderá ser inscrita num desejo particularizado" (SOLER $\left.{ }^{188}, 2005: 103\right)$.

No desenvolvimento da teoria psicanalítica, a mãe passou por transformações. De Freud a Lacan, a visão do papel e da função da mãe transformou-se com as mudanças culturais do lugar da mulher. Em Freud, a mulher não podia separar-se da figura da mãe. Em sua teoria do Édipo feminino, inclusive, a maternidade era a saída apontada por ele como a mais "saudável" para a resolução do conflito edípico. Para Freud, o filho viria a substituir simbolicamente, para uma mulher, o pênis paterno desejado e não recebido quando menina. Para o filho, por sua vez, seja do sexo masculino ou feminino, a mulher enquanto mãe irá se constituir como o primeiro objeto de desejo. Nas palavras de Soler, comparando o lugar da mãe em Freud e em Lacan:

Para Freud, em sua construção do mito de Édipo, a mãe é essencialmente um objeto. E objeto quer dizer, aqui, objeto erótico, cobiçado e passível de ser perdido. Seguindo essa linha, quis-se enfatizar mais seu corpo que sua fala. (...) Contudo, uma vez distinguido o Imaginário, o Simbólico e o Real, na teoria lacaniana, percebe-se que esse objeto também é o Outro, a potência simbólica que detém o poder dos oferecimentos da fala. São as palavras da mãe, seus imperativos e seus comentários, que inscrevem na memória a voz, às vezes devastadora e persecutória, que o analisando evoca com tanta frequência ${ }^{189}$.

Como se verifica, Lacan se afasta de Freud, no que diz respeito à visão sobre a posição feminina, para começar, por sua recusa a interpretar a mulher pela mãe e a ratificar a depreciação freudiana. Para Freud, como foi afirmado, o amor de um homem culmina no filho esperado, à margem da relação sexual, como único objeto "causa de desejo" para a mulher. Mas responder à questão do desejo sexuado da mulher pela progenitura é muito paradoxal, pois a mulher não é a mãe. O filho decerto é um objeto pequeno a possível para uma mulher, conforme afirma Lacan, só que "decorre da

\footnotetext{
188 Id., ibid., p.103.

189 ld. Ibid., p. 99.
} 
dialética fálica do ter, que não lhe é própria, e só raramente satura o desejo sexual; o ser propriamente feminino, se é que existe, situa-se noutro lugar" (LACAN $\left.{ }^{190}, 1995\right)$.

Como a função materna é algo que se opera na criança através da relação daquele que se coloca como o Outro primordial, que faz a função de mãe, e, no caso de uma mulher, não é algo da ordem de um instinto materno que, segundo a psicanálise, trata-se de uma ideia que faz parte do imaginário mitológico da cultura, a maternagem e os cuidados com o pequeno bebê muitas vezes podem trazer, de início, angústias àquela ou àquele que os exerce. Segundo Soler:

A angústia referente aos cuidados a serem prestados ao recémnascido é um fato notável. Há um pavor de não saber lidar com essa coisa viva, esse bebê que não fala, que ainda não está sujeito ao recalcamento, portanto, e que por isso presentifica uma proximidade maior do gozo da vida como gozo ainda não marcado. Há mães que se apavoram com esse objeto, que imaginam já não saber fazer sequer o que todos os mamíferos sabem por instinto: carregar, alimentar, aquecer, etc. ${ }^{191}$.

Para a jovem mãe ou pai, no caso, é muito comum utilizar-se do recurso de voltar para a própria mãe, recorrendo a seu saber, ainda que a angústia se dê, muitas vezes, na medida das censuras que esta última tenha a Ihe fazer. Nos dizeres de Soler:

é a relação com o gozo vivo (da criança que chora, por exemplo) que se mobiliza aqui e que, em todos os casos, é função dos recalcamentos da própria mãe, (ou seja, aquilo que se esqueceu da relação com esta). Assinalo, aliás, que as reações frente aos bebês estendem-se muito além das mães, e sob formas sempre muito vivamente contrastantes, que vão do gosto à aversão, do mal-estar angustiado à paixão fascinada, da indiferença estudada à vocação permanente ${ }^{192}$. (parênteses nossos).

\footnotetext{
190 LACAN, J. O Seminário, livro 4 - A relação de objeto (1956-57). RJ: Zahar, 1995.

191 Id. Ibid., p. 101.

192 Id. Ibid., p. 102.
} 
A guisa de conclusão, coloca-se a questão de qual o valor da mãe, então, para a humanização do filho. Ao que se refere à relação não-patológica da criança com a mãe, ou seja, a que possibilita à criança seu desenvolvimento e constituição de sua própria subjetividade, conclui-se que, para a criança, a dedicação materna tem um valor tanto maior quanto mais a mãe não é toda sua, e "quanto mais não está toda num alhures insondável: mas é preciso que seu amor de mulher esteja referido a um nome. Só há amor por um nome, dizia Lacan: no caso, o nome de um homem, que pode ser qualquer um, mas que, pelo simples fato de ser nomeável, cria um limite para a metonímia do falo, assim como para a opacidade do Outro absoluto. Só mediante essa condição é que a criança poderá ser inscrita num desejo particularizado" (SOLER ${ }^{193}$, 2005:103).

\section{2: O PAPEL DE PAI, A FUNÇÃO PATERNA E O PAI-SINTOMA.}

Desde o final do século XIX o conceito de paternidade e a sua vivência concreta têm sido alvo de reflexões e debates. Com o processo de declínio do patriarcado, a partir do final do século XVII, pôs-se em xeque o lugar do homem enquanto pai e chefe de família, como figura de autoridade e poder dentro do contexto familiar, que assumia, por vezes, posturas autoritárias e até tirânicas, subjugando o lugar da mulher e dos filhos. Ao mesmo tempo em que era uma figura temida e odiada, o pai era admirado e invejado, principalmente pelo filho, em seu lugar de poder e amado pela filha como o seu protetor e guardião. Nos anos 50, Lacan já anunciava o declínio da imago paterna na cultura de sua época. Porém, enquanto discurso normativo de valores e de papéis

${ }^{193}$ Id. Ibid., p. 103. 
familiares, o patriarcado atravessou os tempos e ainda deixa suas marcas na constituição das famílias na atualidade (NARVAZ E KOLLER ${ }^{194}$, 2006).

No Brasil, a história da instituição familiar teve o modelo patriarcal como ponto de partida, importado pela colonização e adaptado às condições sociais do Brasil de então, latifundiário e escravagista (SAFFIOTI, 1979; XAVIER ${ }^{195}$, 1998). Apesar da desintegração do patriarcado rural, que ocorreu de forma diferenciada em diversas regiões do Brasil, a mentalidade patriarcal permaneceu na vida e na política brasileira através do coronelismo, do clientelismo e do protecionismo (CHAUí ${ }^{196}$, 1989).

No imaginário social atual, o papel da mãe ainda remete ao cuidado dos filhos, enquanto o papel do pai, além de prover o sustento, envolve questões de disciplina e de autoridade. A responsabilidade pelas tarefas domésticas e pelo cuidado dos filhos é predominantemente feminina. O papel prescrito às mulheres é o de que sejam cuidadoras do marido, do lar e dos filhos. Essa prescrição parece ter atravessado os séculos, materializando-se na crença de que a mãe deveria dedicar-se integralmente aos filhos. Embora a participação dos homens nas famílias seja precária, persiste o modelo do homem como provedor e de autoridade.

Apesar das prescrições normativas herdeiras do patriarcado, as famílias desvelam em seu bojo marcas de subversão e de resistência às normatizações impostas, emergindo daí papéis familiares cotidianamente vividos de forma plural, heterogênea, criativa e subversiva. A ordem patriarcal, apesar de prescritiva e normativa na estruturação dos papéis e das relações familiares foi, em muitas situações, subvertida. Os homens, muitas vezes percebidos como provedores econômicos, efetivamente não o são, ao menos de forma exclusiva. As mulheres também contribuem com seu trabalho ao sustento econômico da família, ainda que desvalorizem sua capacidade de trabalho. Os homens, mesmo não sendo os principais cuidadores dos filhos, podem ser fonte de apoio, de cuidado e proteção, mesmo de filhos que não são seus do ponto de vista biológico. As mulheres, às quais são atribuídos os papéis de cuidado do marido, do lar e da prole, também cometem

\footnotetext{
194 NARVAZ, Martha Giudice; KOLLER, Sílvia Helena - Famílias e patriarcado: da prescrição normativa à subversão criativa. Psicol. Soc. vol.18 no.1 Porto Alegre, U.F.R.G.S., Jan./Apr. 2006. (Acesso pelo buscador "Google acadêmico", Revista 'Scielo', em 21-11-2010).

195 SAFFIOTI, 1979; XAVIER, 1998; apud NARVAZ E KOLLER, op.cit.

${ }^{196}$ CHAUÍ, 1989; apud NARVAZ E KOLLER, op.cit.
} 
transgressões, abandonam a família, traem os maridos e fogem com amantes, subvertendo, assim, as prescrições de obediência e de submissão das mulheres à figura masculina reguladas pela ordem patriarcal.

Tal subversão dos papéis sociais parece apontar na direção do que se vem tratando neste capítulo sobre as funções parentais na ótica psicanalítica. De fato, como foi afirmado a respeito da função materna, o sexo ou gênero daquele que a exerce não é, como aponta Lacan e outros psicanalistas de linha francesa, preponderante. As funções parentais em psicanálise não se referem diretamente à pessoa, mas à operacionalização e efetividade a partir de lugares simbólicos que o sujeito pode ocupar diante do infans, o sujeito infantil. A ruptura das rígidas barreiras que separam os papéis do pai dos da mãe ratificam a desvinculação dos sexos ou gêneros das funções parentais psíquicas que a psicanálise já anunciara.

Ainda em relação ao papel do pai, ou seja, às expectativas sociais quanto ao desempenho do homem - numa colagem imaginária do papel ao sexo ou ao gênero masculino - no lugar de pai, encontram-se estudos, por exemplo, de Balancho ${ }^{197}$, psicóloga portuguesa, que dedicam-se essencialmente à identificação e caracterização de eventuais mudanças nos comportamentos e atitudes do pai na relação com os filhos e na vida familiar. A visão de um possível "pai reconstruído" é entendida por alguns como não mais do que uma esperança do mundo ocidental e industrializado - quer dos grupos científicos e dos ativistas sociais, quer das próprias mulheres desejosas em partilhar uma função que as sobrecarrega - e bem longe de uma realidade objetiva. Em realidade, o fenômeno a que se assiste é o da "nova mulher", entendendo que após sua entrada no mundo do trabalho na década de sessenta, com uma sobrecarga de tarefas consequente à acumulação das responsabilidades domésticas, e ao ver-se mãe só por escolha biológica, imposição ou divórcio - a mulher desejou, idealizou e tentou construir um novo parceiro, transformado em suas funções familiares e mais colaborador, atuante e interveniente na educação dos filhos.

\footnotetext{
${ }^{23}$ BALANCHO, L. S. F. "Ser pai: Transformações intergeracionais na paternidade". Análise Psicológica, jun. 2004, vol.22, no.2, p.377-386. Instituto Superior de Psicologia Aplicada, Lisboa, 2004. - Google Acadêmico - Acesso pelo buscador “Google acadêmico”, Revista 'Scielo', em 21-11-2010).
} 
Diferentemente do que ocorre na atualidade, os pais foram já largamente conotados de forma negativa: como inacessíveis, insensíveis, inadequados, incompetentes e inconsistentes na percepção descritiva de que desfrutam, nas expectativas que criam e no comportamento que desempenham (BELSKY, 1984; MACKEY, $1985^{198}$ ). É certo que muitos pais ainda se vêem como tendo meramente um papel de suporte e apoio na educação dos filhos (KELLEY, 1997; KELLEY et al., $\left.1998^{199}\right)$, não se vislumbrando como atores principais na formação da prole. Ser soldado e ama de crianças pode ainda surgir no imaginário masculino como uma contradição insustentável, mais do que como duas formas complementares de ser homem (MACKEY, $1985^{200}$ ). Ainda mais que, segundo Elisabeth Badinter, importante filósofa francesa pesquisadora das identidades masculina e feminina, a construção da identidade masculina se apoia no negativo. Para Badinter ${ }^{201}$, pelo menos no Ocidente, ser homem sempre foi mais imperativo do que indicativo, mostrando que a virilidade não estava dada, mas sim, tinha de ser provada. A própria construção dessa identidade aparece muitas vezes como um negativo, tendo os homens que aprender antes o que não ser para depois o que ser. Ser homem, dessa forma, é NÃO ser feminino, homossexual, dócil, submisso ou dependente e, principalmente, impotente com as mulheres. Por outro lado, ser potente sexualmente depende de uma geografia do órgão sexual que realiza a ereção, a penetração e a ejaculação. A prova da potência é ao mesmo tempo o fantasma da impotência. Essa precária fronteira provavelmente desenhou um modelo de identidade masculina sempre sob ameaça, o que justificaria tanto sua construção defensiva, quanto um longevo consenso entre os homens pelo resguardo dessa fragilidade.

Segundo Balancho ${ }^{202}$, os papéis que o pai desempenha na vida dos filhos mudaram nas últimas décadas em alguns parâmetros. O pai contemporâneo (especialmente aqueles com crianças pequenas) tem de si mesmo a imagem de possuir uma maior responsabilidade pelo cuidado diário dos filhos, e a evidência empírica demonstra que esses pais passam mais tempo com eles do que passavam os de

\footnotetext{
${ }_{198}$ BELSKY, 1984; MACKEY, 1985 apud BALANCHO (2004), op.cit.

${ }^{199}$ KELLEY, 1997; KELLEY et al., 1998 apud BALANCHO (2004), op.cit.

200 MACKEY, 1985 apud BALANCHO (2004), op.cit.

201 BADINTER (1993) apud HADDAD, Gisela. - Amor e Fidelidade. SP: Casa do Psicólogo, 2009.

202 BALANCHO, L. S. F. (2004). Loc. cit
} 
gerações anteriores. Ainda que muitos refiram que a quantidade de tempo investido pelos pais nas atividades relativas à paternidade não aumentou substancialmente, mas apenas de forma discreta e modesta, há indicadores de uma maior flexibilidade nos tipos de atividades em que os pais se envolvem com os filhos. Apesar da evidência consistente de modestos aumentos nos níveis de envolvimento, Balancho afirma que não é ainda clara a consistência generalizada dessa mudança, nem o seu alargamento a todas as culturas e níveis sócio-econômicos e culturais.

Apesar de todas essas mudanças apontadas no papel do pai, pode-se afirmar o mesmo em relação à função paterna?

Para a Psicanálise, - como visto no capítulo sobre o Édipo - o pai é uma função. Esta última indica a especificidade que a questão toma no campo analítico, indo além do senso comum do significado de pai. "A função paterna é nuclear na medida em que está na origem da constituição de todo sujeito, e este é sempre submetido à lógica significante que ordena o campo da fala e da linguagem"203. Neste sentido, o pai só terá interesse para a constituição subjetiva na medida em que ele é uma função, e não uma pessoa. Desde que haja alguém que cumpra a função de terceiro, interditando a mãe à criança, frustrando-a e privando-a da reintegração de seu produto, o espaço para a constituição subjetiva bem como a interrogação sobre o desejo estarão preservados.

Em outras palavras, a função paterna é "a função de interdição sobre a qual repousa a cultura, interdição fálica de um gozo que seria ilimitado se a morte não viesse antes e estragasse a chance de desfrutá-lo. Em nossa cultura ocidental, essa função recai sobre o pai simbólico, que interdita o que no registro do real é o impossível e no registro do imaginário é vivido como impotência ${ }^{204 "}$.

Lacan ensina que é como objeto, ou seja, submetido ao desejo do outro, que um sujeito tem seu lugar no mundo. "Essa condição de submetimento ao significante é da ordem da lei do Pai, que, interditando o gozo incestuoso, destina a satisfação pulsional à ordem fálica. Ou seja, protege a criança do desamparo fundamental e a insere na ordem simbólica, possibilitando que ela deseje. A passagem do sujeito à referência

\footnotetext{
${ }^{203}$ NAZAR, Maria Tereza Palazzo (org.). - Psicanálise e Pesquisa: A Função Paterna. - RJ: Cia. de Freud: Escola Lacaniana de Psicanálise, 2008. (Psicanalise E Conexões, Vol. 1).

${ }^{204}$ BETTS, Jaime Alberto. "Missão impossível? Sexo, educação e ficção científica". In: APPOA (Associação Psicanalítica de Porto Alegre). CALLIGARIS, Contardo. (org.) - Educa-se uma criança? Porto Alegre: Artes e Ofícios, 2010, p.61.
} 
paterna de constituição triangular, o complexo de Édipo, inaugura o funcionamento simbólico, quebrando a relação especular de rivalidade com o outro materno, relação paralisante e mortal. Só desta forma a lei Paterna pode ser internalizada, dando lugar para o amor ao pai, amor ao significante"205.

A inserção simbólica, e somente ela, é capaz de garantir à criança um determinado lugar na família, tornando-a produto de duas linhagens. Num primeiro momento, para que uma criança tenha direito à infância, é preciso que ela se referende no desejo de um outro que lhe garanta a existência. É impossível garantir tudo, mas é fundamental reconhecer uma falta estrutural, lugar onde a criança deverá advir, dentro de princípios e valores que ela própria precisará ressignificar. É a lei paterna, internalizada pela mãe, que possibilitará a assunção dessa falta para a criança, com a permissão da entrada do pai simbólico, o significante do Nome-do-pai, nomeado pela mãe, e, na grande maioria das vezes, representado pelo pai real, da realidade.

Diante da ameaça de ser capturado pela demanda do outro, numa imagem que o antecede, o sujeito, para se constituir, não pode prescindir do limite oferecido pela linguagem. Por sua estrutura de metáfora, a linguagem direciona o circuito pulsional. É essa a função que Lacan nomeou Paterna, operação metafórica que introduz o significante. Verifica-se na clínica que esta função representada pelo pai, mas não exclusivamente dependente de sua presença física, domina e arbitra sobre as primeiras relações dilacerantes, verificadas na fantasia de toda criança, com a mãe e com o rival fraterno. A função paterna oferece o valor que as dimensiona e estabiliza, ou seja, a instalação do complexo de Édipo e de castração. Trata-se de uma operação lógica que se estabelece a partir do lugar do pai como representante do desejo da mãe. Tal operação psíquica permitirá a entrada do sujeito na linguagem e no laço social, em geral, no seu primeiro grupo social que é a família.

O convívio com pais, avós, tios, primos estabelece uma rede de relações, necessária à constituição da cena edípica, base para a referência identificatória. É nessa rede que o sujeito vai encontrar elementos para orientar a posição em relação ao seu próprio sexo biológico, sua relação com o outro e com o mundo, ou seja, uma forma

\footnotetext{
${ }^{205}$ NAZAR (2008), op. cit.
} 
de organização pulsional. Do contrário, Ihe restará a alienação isolacionista, fonte de recursos à marginalidade.

A função paterna inaugura a instância da Lei da interdição do incesto, da barragem do gozo impossível e da instância do ideal de eu, responsável, segundo Freud, pela consciência moral, possibilitando a relação do sujeito com o outro, regulada por regras e valores simbólicos. Devido à sua incapacidade de sobrevivência sem um outro semelhante, o sujeito humano é um ser destinado ao social. Tal dependência impõe necessariamente uma restrição dos seus impulsos mais primitivos e o divide entre sua extrema dependência do outro - alienação fundamental para todo ser falante -, e o desejo de aniquilação e destruição, revolta que o limita e que reprime. É justamente a falta que se coloca para o humano, que responde pela sua possibilidade de criação e desenvolvimento. O que o diferencia dos outros seres é sua possibilidade de falar, seu acesso e submetimento à linguagem.

Para Freud, um sujeito é regido pela lei do desejo inconsciente, ou seja, o atravessamento do complexo de Édipo, solução determinante para a renúncia ao impossível de seu gozo, preço da liberdade de uma satisfação possível e duradoura. No entanto, o imperativo de gozo pode ultrapassar a Lei, levando o sujeito a atuações diretas, ultrapassando, inclusive, as leis externas e imaginárias, que, por isso, são necessárias. Ainda que não seja suficiente que um sujeito aja determinado exclusivamente por exigência moral, o processo de estabelecimento de uma ética propõe uma implicação pessoal, um convencimento íntimo em relação aos princípios de uma moral. Dessa forma, as leis externas, a dos códigos, podem ser compreendidas como projeção, no social, na cultura, da lei simbólica advinda da função e da metáfora paterna.

Uma das contribuições de Freud foi apontar as consequências do complexo edípico e da função paterna como originárias das neuroses. O que é um pai é uma questão sem resposta, mas é a ocasião de uma elaboração permanente. Freud ao mesmo tempo respondeu, dizendo: "o pai é o resultado de um processo cogitativo". O que significa que o pai é uma construção mental do filho e é em relação a esta representação que todo filho se tornará, por sua vez, pai. 
"Qual o lugar do pai?". É uma questão característica de nossa época. "Mater certa. Pater incertus". Freud já indicava, que o lugar do pai é frágil, não podendo se sustentar sem o escoramento institucional que lhe serve de legitimidade e apoio. Da parte do homem, antes de ser uma realidade biológica, a paternidade é um ato responsável de adoção. É uma aventura psíquica, uma mutação subjetiva que cada homem conhece ao confrontar-se com o fato de tornar-se pai. A função paterna não existe somente sob a forma de identidades perceptíveis na realidade, mas também no limite da experiência humana, lá onde se vestem as figurações fundadoras do Outro.

Lacan apontou a função paterna como o pivô da constituição subjetiva, o pilar da construção que define o sintoma que responderá pela singularidade desse ser falante. O papel da família na gênese das neuroses relaciona-se ao duplo encargo do complexo de Édipo. É a dinâmica do complexo edípico que regula a estruturação do eu, inicialmente pela relação do sujeito com o outro primário no processo de construção narcísica e, posteriormente, na relação com a realidade, com o social e a cultura, a partir da operação da metáfora paterna e interdição da lei do pai.

O pai, através de sua palavra, funda um lugar terceiro junto à mãe e à criança, impedindo esta de ser tudo para sua mãe, protegendo-a de uma relação fusional, ou seja, promovendo um corte e estabelecendo um lugar desejante para a criança. Não se trata da presença ou ausência do pai e sim de uma operação simbólica que efetua uma dupla castração: para a criança e para a mãe. Este lugar terceiro ocupado pelo pai priva a mãe de designar a criança como seu objeto de gozo. A mãe, privada de possuir de forma irrestrita o objeto do seu desejo ( o filho), possibilita a instauração da Lei fundadora do desejo. É só como efeito da marca da metáfora paterna estabelecida em sua trama edípica que a mãe pode funcionar como portadora da palavra do pai. Com isso, pode-se dizer que é pelo valor dado pela mãe à palavra do pai que se instaura um lugar onde este vem ocupar uma posição de autoridade. Lacan, no Seminário 5 , diz que "o pai é um significante que substitui um outro significante: "a função do pai no complexo de Édipo é ser um signifcante que substitui o primeiro significante introduzido

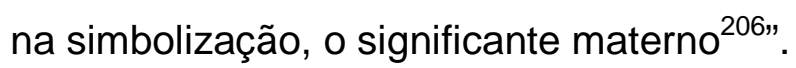

\footnotetext{
${ }^{206}$ LACAN, J. - O Seminário - livro 5: as formações do inconsciente (1957-1958). RJ: Jorge Zahar,
} 1999. 
O desejo do sujeito nasce a partir do desejo do Outro, ali onde tomam lugar os significantes da história do sujeito. É nesse campo do Outro que o sujeito vai encontrar uma significação. Com o nome que ele recebe, se inscreve numa cadeia geracional e marca suas insígnias. Seu pai irá nomeá-lo com o próprio nome num ato de nomeação que Lacan diz ser um fenômeno que designa um traço especial e unário, marcando que aquele filho é o que os outros não são; ele se investirá de uma série de conotações significantes que adquirirão existência e consistência. A transmissão deste nome se faz automaticamente, sem que se julguem as qualidades dos filhos. Os filhos recebem este nome próprio proveniente de um mais além de seu pai, um enigma, algo maior , que é o pai simbólico. O sujeito que exerce a função de pai na sua efetividade simbólica transmite a lei. Quando nasce uma criança e esta vai ser registrada, é necessário que o pai declare "esse é meu filho", "esse é meu nome". O pai é, então, o encarregado da sucessão, assegurando a ordem pela qual cada um vem encontrar o seu lugar numa cadeia, cadeia significante instaurada desde então por ele.

A identificação com os pais, dessa forma, vai representar a resposta da criança ao desejo deles, é uma estratégia inconsciente para engendrar o gozo do Outro, a fim de se assujeitar a ele e se tornar objeto do seu gozo. A criança se dá conta dos significantes da acolhida oferecida para ali inserir os elementos de sua pré-história.

Num momento mais avançado de sua elaboração teórica, Lacan irá rever a questão do pai, redefinindo um pai, digno desse nome, como um sintoma e, segundo Soler $^{207}$, "lar do pai como sintoma é defini-lo por um modo de gozo". Há total inversão nesse momento da teoria em relação ao pai morto do Nome-do-Pai, o pai simbólico da elaboração teórica dos anos 50 e 60. No seminário R.S.I, de 1975, Lacan elabora em seu novo formalismo do sintoma outras duas definições novas, solidárias em sua lógica: precisamente a do sintoma pai e a da mulher-sintoma. "Um pai não tem direito ao respeito, mas ao amor", diz Lacan. E "só tem direito ao respeito quando é 'perversamente' (père-versement) orientado. Ei-lo incluído, portanto, no todo da perversão generalizada do homem 208 ". Mas não convém que ele seja "qualquer um", sob pena de rejeição, embora seja preciso "que qualquer um possa constituir uma exceção para que

\footnotetext{
${ }^{207}$ SOLER, C. - O que Lacan dizia das mulheres. RJ: Jorge Zahar, 2005, p.177.

${ }^{208}$ Idem, ibid.
} 
a função de exceção se transforme em modelo", diz Lacan ${ }^{209}$ (apud SOLER, 2005). Soler demonstra que nessa formulação, há um uso duplo da expressão 'qualquer um'. Retomando as fórmulas da sexuação, em que o homem é definido em relação a ser todo-fálico, qualquer um do conjunto de todos os homens deveria poder atingir a função. Porém, nesses todos, somente os pais dignos desse nome são modelos da função: aqueles que teriam o sintoma-pai, ou seja, um modo de gozo que envolve a questão da paternidade, do 'ser pai'. Logo, não-todos os homens e, portanto, não qualquer um. "Assim, o conjunto de todos os homens divide-se em dois subconjuntos: 0 dos pais que não são qualquer homem, porque têm o sintoma pai - e, nesse caso, não importa que tenham outros sintomas - e o subconjunto dos que não têm esse sintoma pai” (SOLER $\left.{ }^{210}, 2005\right)$.

Vê-se, então, que a questão levantada é a da diferença entre o 'Pai' e o 'Homem', o universal do Homem definido pelo Um fálico. Sua nova definição do pai, aliás, Lacan a formulará em duas etapas. Num comentário "realmente exorbitante", na opinião de Soler, Lacan afirmou que o Pai é "aquele que faz de uma mulher o objeto a que causa seu desejo". E Soler aponta, sob forma de questão, se não é essa, aparentemente, a definição de todo homem heterossexual, que só deixa de fora de seu campo o conjunto dos defensores da ética ex-Sexo (fora do sexo) ${ }^{211}$ do celibatário ${ }^{212}$, os quais, por sua vez, não fazem de uma mulher o objeto-causa. Isso equivale a dizer que, no todo homem $(\forall \mathrm{x} . \Phi(\mathrm{x}))$ da 'per-versão' (père-version) generalizada, o Pai, segundo Lacan, fica do lado do subconjunto dos héteros", entendido aqui como qualquer sujeito que toma uma mulher - ou o Outro sexo - como seu parceiro-sintoma.

Soler sintetiza, então, de forma bastante esclarecedora, a questão do pai, apontando a diferença da posição psicanalítica em relação a uma visão ideológica e normatizada do papel de pai. Citemo-la:

\footnotetext{
209 LACAN, J. apud SOLER, C., op. cit.

210 SOLER, C., op. cit.

211 Parênteses nossos.

212 Termo utilizado na acepção lacaniana, que designa não o fora do casamento e a ausência de uma esposa, porém as diversas posições libidinais em que a mulher não é o objeto. (N. de Soler, 2005, op. cit.).
} 
Um Pai não é 'qualquer um'; é um modelo. Mas um modelo da função pai. Esse modelo não é comum e não exige dele que ele seja um pai modelo, longe disso. A normalidade não é o que define: pouco importam seus próprios sintomas, bem como suas aptidões ou seus talentos e tudo o que possa haver de exemplar em sua pessoa. Sua função nada tem a ver com a consideração de seus atributos ideais, dos quais Lacan zombou amplamente desde o começo, ironizando as pesquisas que, perseguindo a carência paterna "entre o pai tonitruante $e^{213}$, o pai indulgente, o pai onipotente, o pai humilhado, o pai acabrunhado, o pai derrisório, o pai caseiro ou o pai passador", perdemse numa fenomenologia do pai, (nos semblantes) ${ }^{214}$, sempre mais ou menos normativa. Medíocre ou eminente, não é essa a questão: o Pai como tal só é modelo da função, para a qual, não existem graus, não há mais nem menos: ou ela é satisfeita, ou não é. Mais que um Nome, pai, aqui, é uma questão de desejo, preso que está a uma das modalidades da causa do desejo masculino. A metáfora paterna fazia do desejo da mãe a precondição e a mediação necessária à função do Nome-do-Pai. Mas agora estamos longe das teses enunciadas em "De uma questão preliminar a todo tratamento possível da psicose" - embora já encontremos nesse texto uma observação discreta sobre a subjetividade paterna como tal. Numa perspectiva inversa, se bem que não contraditória, o suporte da função é colocado, aqui, do lado do Um pai, tomado como sujeito, ou melhor, como 'falasser'. A fórmula de seu sintoma poderia ser: fazer de sua mulher, ou da mulher eleita, uma mãe $e^{215}$.

Dessa forma, pode-se perceber claramente que não se trata de um desejo qualquer do homem, pois, segundo Soler ${ }^{216}$, "muitos homens não recuam diante do sexo, nem tampouco diante da escolha de uma eleita; recuam, entretanto, como é notório, quando se trata de assumir a transmissão da vida, atendo-se mais à formulação: mulher, sim, mãe, não".

Ao pensar a função paterna e suas relações com o desejo de filho, Claude Dumézil ${ }^{217}$, psicanalista francês de orientação lacaniana, afirma: "o desejo de filho é atravessado pela questão do desejo de um homem e/ou de uma mulher de ter uma criança incluída (ou não) no amor que esse homem tem por essa mulher e

\footnotetext{
213 Tonitruante: que troveja, atroado, estroante, que fala estrondosamente.

${ }^{214}$ Parênteses nossos.

${ }^{215}$ SOLER, C., op. cit.

${ }^{216}$ SOLER, C., op. cit.

${ }^{217}$ DUMÉZIL apud NAZAR, op. cit., 2008.
} 
reciprocamente". Para ele, o legítimo desejo de um filho é aquele dirigido ao pai, o que é interessante de pensar, pois, de alguma maneira, estabelece que é este o agente que fará validar a castração feminina. O pai é insuficiente para responder o enigma sobre a feminilidade, mas é o agenciador do legítimo desejo de filho na mulher. É fundamental, portanto, que os sujeitos engajados no desejo de um filho possam reconhecer-se incluídos como responsáveis, enquanto pai e mãe, pela saúde psíquica da criança.

A partir da elaboração acima da posição do pai, a tentação sempre acessível para o homem de se tornar filho de sua mulher, isto é, a configuração do homemcriança, aquele que espera dela cuidados maternos no nível do substrato da vida cotidiana, solicitude para com seu narcisismo e, às vezes, também até no plano erótico, torna-se bem distinta da posição paterna, ainda que ele seja o progenitor. Por criar obstáculos à posição paterna, um homem identificado a esse lugar de homem-criança pode ser levado a recusar uma paternidade que lhe subtrairia uma parcela dos cuidados maternos de sua mulher, e que o colocaria em rivalidade fraterna com os próprios filhos. Aceitar-se Pai pressupõe, ao contrário, o efeito de separação que permite a um homem deixar a mulher um pouco para os outros, pelo menos para os outros que são seus filhos.

O sintoma-pai nos fornece o exemplo, portanto, de uma nodulação entre o amor por uma mulher, o desejo sexuado e o consentimento em lhe fazer filhos. Nesse ponto se evoca claramente um desejo de paternidade, e distinto de qualquer desejo pedagógico. Soler afirma que Lacan "cliva os cuidados paternos de qualquer vocação educativa". Segue, então, formulando uma distinção entre funções materna e paterna em termos de 'cuidado'. Vejamos:

O cuidado é mais comumente pensado como apanágio da mãe. Quer ela se dedique a sustentar o corpo, quer se empenhe em ser para seu filho a mediadora da linguagem e de seus diversos efeitos, a um só tempo castradores e erógenos, toda a sua solicitude equivale a uma manifestação primeira de seu amor de mãe. Para o pai, não pode tratarse de simplesmente reproduzir esses cuidados maternos. Ponhamos, pois, a seu encargo, com a função separadora de sua presença, afirmada seja de que modo for junto à mãe, o cuidado simbólico: a transmissão do Nome, sempre crucial, porque acarreta a inscrição na 
cadeia das gerações e num desejo que não seja anônimo. (SOLER ${ }^{218}$, 2005).

De forma resumida, a mãe está incumbida, além da gestação e do nascimento, dos cuidados com o corpo e com a tradução das necessidades e do real angustiante da criança em demandas passíveis de satisfação, ainda que parciais, e aplacamento da angústia. Ao pai, cabe a função simbólica de separar e interditar a relação narcísica estabelecida entre mãe e criança, e a de transmitir o Nome, inserindo a criança numa linhagem familiar. Ou seja, mantém-se a essência da primeira elaboração lacaniana em que mãe e pai são lugares e funções eminentemente simbólicas, mas leva-se em conta a teoria da amarração dos registros do simbólico, imaginário e real no 'nó borromeano'.

Soler ${ }^{219}$ afirma que "o sintoma pai não é qualquer um", mas "o sintoma típico do que se pode continuar a chamar de função paterna, desde que se a redefina, como faz Lacan, em termos de nodulação borromeana entre as três consistências do simbólico, do imaginário e do real". Cotejando os dois momentos da teoria lacaniana, Soler nos mostra que "na metáfora paterna, elaborada uns 20 anos antes, o Nome-do-Pai, ao metaforizar o significante do desejo da mãe, para lhe dar seu significado fálico, nodulava o simbólico do significante e o imaginário do significado, fiando o real como que de reserva. As últimas elaborações que se serviram do nó-borromeano foram solidárias da consideração do gozo vivo como real, disjunto, em si mesmo, das outras duas consistências". Diferentemente da teorização dos anos 50 e 60, em que o desejo se colocava como elemento central, a partir dos 70 , é o conceito de gozo que é elevado a esse lugar.

Apesar do claro alcance socializante da formulação de Lacan do pai-sintoma, Soler aponta que resta o problema de saber se esse "é um sintoma em vias de regressão, se pode manter-se além do "declínio do paternalismo" e se pode ser substituído" e que, manifestamente, Lacan não contemplou nisso as parentalidades

\footnotetext{
${ }^{218}$ SOLER, C., op. cit.

${ }^{219}$ SOLER, C., op. cit.
} 
homossexuais, sendo, portanto, uma questão a se incluir no debate sobre as novas formas da família. Segundo afirma:

Não é fácil avaliar com justiça o alcance político dessas teses de Lacan. Por um lado, elas parecem reforçar o casal da família clássica, heterossexual, e poderíamos qualificá-las de conservadoras. Mas, por outro, Lacan trouxe à luz uma dupla disjunção: de um lado, entre a anatomia registrada pelo registro civil e a identidade sexual efetiva, e, de outro, entre essa identidade sexuada do gozo e a escolha do parceiro sexuado. Por isso, heterossexualidade e homossexualidade parecem igualmente aceitáveis como figuras da perversão generalizada" (SOLER ${ }^{220}$, 2005),

pois numa relação heterossexual, os parceiros podem se colocar, conforma a fantasia inconsciente, numa posição de gozo semelhante, assim como numa relação homossexual de fato, o sujeito pode tomar o parceiro numa posição de Outro sexo. Assim, percebe-se o sentido particular que os termos 'hetero' e 'homossexualidade' adquirem no discurso psicanalítico.

Ainda que as sociedades distingam a parentalidade em dois tipos: uma constituída por pais verdadeiros, ou seja, um parentesco fundado em laços sanguíneos, e outra, fruto de uma adoção na qual o parentesco se forma por um outro tipo de circunstância que não a biológica, foi visto que a psicanálise sustenta que a filiação se fundamenta no simbólico. Há, na cadeia da filiação, uma transmissão. Os pais transmitem ao filho aquilo que Ihes foi dado: o nome e a dívida contraída em relação àqueles responsáveis pela sua formação subjetiva, e isso é assim para todos.

Diante da multiplicidade de famílias, os papéis e funções se misturam. As funções e os papéis parentais são correntemente dissociados, a paternidade é exercida por dois, três homens, muitas vezes mesmo por uma mulher, quando não por uma Instituição. A circulação das funções em diferentes figuras não é necessariamente nociva, mas é fundamental que essa função opere efetivamente.

${ }^{220}$ SOLER, C., op. cit. 
A ideologia contemporânea propõe uma substituição constante, pela qual as figuras parentais de referência, os limites podem ser dispensados sem se supor que isso traga consequências. Na cultura contemporânea, a figura paterna de exceção, aquela que orienta a formação do ideal do eu à custa do recalque, encontra-se diluída, fragmentada em inúmeros ideais sociais da ordem de uma mais-valia erótica, política, social, libertadora, que, no entanto, não é capaz de proporcionar o alívio da angústia consequente do desamparo originário da condição humana.

Novos sintomas, novas formações familiares, novas estruturas subjetivas, qualquer que seja a abordagem da questão, a função paterna - o Nome-do-Pai e o paisintoma - fundam a garantia simbólica de inserção do homem no mundo. Ao sujeito, referido à sua falta fundamental, seu desamparo originário, à castração constante e à eterna impossibilidade de completude e apaziguamento psíquico, só lhe resta criar e inventar, servindo-se dos nomes do pai oferecidos pela cultura. 


\section{6: FUNÇÕES PATERNA E MATERNA NA HOMOPARENTALIDADE.}

Neste capítulo, ir-se-á tratar finalmente das funções materna e paterna na parentalidade homossexual - objeto de interesse central deste trabalho. Trata-se do estudo sobre o modo como ocorre o desempenho de cada uma dessas funções nos casais homossexuais gays e lésbicos que criam filhos e que se consideram como um tipo específico de família. Nos últimos anos, como visto em capítulo anterior, há uma preocupação mais premente em relação a essas questões, tendo em vista o surgimento de diferentes modalidades de famílias, de concepção de filhos e, consequentemente, de parentalidades - e, em especial, da homoparentalidade. No período anterior à maior visibilidade e frequência das novas modalidades familiares, as relações pais-filhos eram concebidas sob a ótica do patriarcado, cujos padrões relacionais estavam submetidos à primordial autoridade do pai (do homem), o chefe e provedor da família, ainda que a responsabilidade maior pela criação dos filhos ficasse sob a guarda da mãe (da mulher). Atualmente, observa-se uma expansão das possibilidades de relações amorosas-conjugais e filiais, exigindo uma nova descrição dos processos de subjetivação no interior da família.

Não se pode mais pensar em modelos ou padrões hegemônicos e únicos de família, muito menos de pai e mãe, ainda que prevaleça, em termos quantitativos, a família nuclear tradicional, ou seja, heterocentrada. Contudo, temos de reconhecer que, embora as referências não sejam mais fixas como na era patriarcal, as referências parentais continuam sendo importantes como dispositivos que regulam algumas saídas necessárias à constituição do psiquismo e do sujeito. A autoridade do pai - não aquela do pai onipotente - continua sendo um esteio universal na inserção do sujeito na cultura. Os cuidados da mãe foram, e sempre serão, os fundamentos de que o bebê precisa para criar seus primeiros laços com um outro e dar os primeiros passos na criação de seu lugar na cadeia familiar. Tais são os lugares e funções imaginaria e culturalmente reconhecidos, designados às funções parentais.

De um modo geral, os pais são para os filhos, referências de afeto e reconhecimento necessárias para que eles se constituam psiquicamente. Além disso, o 
pai e mãe devem oferecer suas histórias para que a criança possa explorá-las, fantasiálas e, assim, criar e recriar seus próprios roteiros, um dos recursos de que a criança precisa para prosseguir em um processo de amadurecimento, já iniciado mesmo antes de seu nascimento.

Dentre todos os requisitos e condições para a parentalidade homossexual jurídicos, políticos, econômicos e socioculturais -, caberá ressaltar, neste momento, o aspecto psíquico. Do ponto de vista psicanalítico, o que move um sujeito em direção a ter e criar um filho é o desejo de criança. Deste modo, o que visa o analista é o questionamento sobre este desejo de criança de um sujeito pode ou não sustentar. De onde surge tal desejo? Desde cedo ou não, um sujeito pode vir a sonhar em ser pai ou mãe. Querer ter um filho ou constituir laços que se configurem em uma família, independentemente de sua escolha de objeto, é um desejo que pode fazer parte do inconsciente do sujeito. E a que responderia tal desejo? A um ideal de pai, muitas vezes; a uma fantasia de reparação; a uma comprovação narcísica de sua capacidade; ou até mesmo uma saída ao seu complexo edípico. Muitas são as hipóteses que só podem ou não ser corroboradas na singularidade de uma fala em transferência, isto é, no caso a caso da clínica analítica.

Segundo Passos ${ }^{221}$, psicanalista, professora doutora em psicologia clínica e uma das pioneiras no Brasil em pesquisas sobre homoparentalidade e psicanálise, as funções parentais têm um caráter operacional, cuja "finalidade precípua é sustentar a criança ainda imatura, oferecendo-Ihe uma contenção de seus impulsos e levá-la a expandir e desenvolver seus recursos psíquicos herdados". Essas funções têm sentidos e perspectivas diferentes, de acordo com o momento de vida da criança. Em primeiro lugar, parece haver consenso em relação ao fato de que é a mãe que assume, nos primeiros meses de vida, a maior responsabilidade sobre a inserção do bebê em um ambiente, do qual ele vai retirar as condições necessárias para a sua sobrevivência física e para a sua inserção em um mundo simbólico. Ao pai caberia, nessa etapa, dar

${ }^{221}$ PASSOS, Maria Consuelo. - "Funções Materna e Paterna nas Famílias Homoparentais". IN: FÉRESCARNEIRO, T. (ORG.) - Família e Casal: Saúde, Trabalho E Modos De Vinculação. São Paulo: Casa Do Psicólogo, 2007. 
suporte à mãe para que ela apresente o mundo ao bebê e se ofereça como a fonte de sua subsistência física e emocional.

Passos $^{222}$, norteando-se pela teoria psicanalítica lacaniana, estabelece cinco condições necessárias para uma criança sobreviver e se inserir numa cadeia simbólica que a levará a se tornar um sujeito.

Em primeiro lugar, a criança precisaria ser acolhida com os cuidados necessários a sua subsistência física e psíquica, sendo necessário, para tanto, que a mãe se identifique com a criança para poder assimilar os seus pedidos, que se expressam através do choro, dentro outros comportamentos motores, e, assim, atendê-los com atenção e coerência.

A segunda condição fundamental é a necessidade da inserção do bebê na cadeia simbólica de filiação e, para tanto, ele deve ser reconhecido pela mãe como filho (a). Esta condição pressupõe uma terceira, a de que a mãe já esteja alocada nesta cadeia, em um lugar complementar ao do bebê. Isto significa que, para assumir este lugar, a mãe teria revisitado os primórdios de sua existência como filha e pôde, partindo dessa origem, criar e abastecer sua posição de receptora, aquela que abrirá um espaço para a colocação da criança nessa nova rede familiar.

O quarto ponto diz respeito à inserção do pai na relação mãe-filho(a), configurando, agora, uma triangulação necessária à produção de um mundo simbólico. O pai deve oferecer-se como o elemento diferente, que rompe com essa relação e dá suporte para que haja a contenção das tendências pulsionais da criança.

Por fim, é preciso ressaltar uma condição que - embora de natureza diferente das anteriores - se constitui como fundamento importante para o amadurecimento infantil: o conhecimento que a criança precisa ter de sua origem, seja ela qual for. Tratase de uma questão que tem gerado muitas polêmicas atualmente, principalmente porque as formas de procriação são muito variadas e algumas delas encontram ainda muitas resistências na sociedade, o que leva muitos adultos a silenciarem tal questão às crianças provenientes de procriações diferenciadas da tradicional, a da relação sexual entre um homem e uma mulher.

${ }^{222}$ PASSOS, M. C. - loc.cit. 
No entanto, sabe-se, a partir de estudos de outros psicanalistas fundamentalmente os de Maud Mannoni e Françoise Dolto -, da importância para a criança desse saber sobre sua origem bem como dos efeitos negativos da manutenção do 'segredo' dos pais em relação a esse saber. O não-dito, o silêncio, já é uma forma de discurso, e ainda que a criança não possa nomear esse saber não-dito, ela sabe de sua existência e pode responder a ele através de sintomas.

Quando se fala de parentalidade, refere-se a uma relação que tanto pode ser construída por consaguinidade quanto por aliança. É esta última que nos interessa mais de perto, uma vez que ela pressupõe que a constituição psíquica enquanto processo de relações intersubjetivas e da transmissibilidade entre gerações ascendentes e descendentes, independentemente da reprodução ou procriação genético-biológica.

Passos $^{223}$ afirma que tais relações interpsíquicas iniciam sua estruturação bem cedo. A autora aponta cinco tipos de representação que a mãe faz de seu bebê a partir das relações estabelecidas com o mesmo: o bebê imaginário; o bebê fantasmático; o bebê narcísico; o bebê cultural e o bebê real. São diferentes representações que se alternam e permitem à mãe se adaptar às necessidades do bebê, ao mesmo tempo em que mãe e filho configuram, reciprocamente, seus lugares na cadeia familiar. Nesse sentido, é possível depreender-se que, do ponto de vista analítico, para a constituição do psiquismo, ou seja, para o estabelecimento desse laço inicial e consequente estruturação subjetiva, é necessária uma disposição psíquica do cuidador, do Outro primordial que, por sua vez, pode ser encarnado por uma figura - pessoa - de qualquer sexo, desde que tenha essa disposição a identificar-se às necessidades e demandas do bebê, fornecendo-lhe elementos e recursos para atravessamento da angústia de desamparo ('Hilflosigkeit', em termos originais freudianos).

A instauração da parentalidade depende, portanto, dos recursos intrapsíquicos que permitem aos pais desejar simbólica e imaginariamente seus filhos, investindo-os libidinalmente (afetivamente), a fim de poder criá-los como sujeitos desejantes e psiquicamente saudáveis. Porém não só isso. Tais condições dependem também de como esses pais foram, nos primórdios da sua infância, inseridos em suas redes

\footnotetext{
${ }^{223}$ PASSOS, M. C. - loc.cit.
} 
parentais de origem. O tornar-se pai e mãe exige um movimento de retorno às suas relações mais primárias, lugar onde cada um reescreve uma nova posição na cadeia geracional. O retorno à rede familiar atual, dessa forma, deve indicar as possibilidades de cada sujeito da parentalidade, de investir, criar e sustentar os laços com os filhos.

A noção de filiação, por sua vez, está ligada à reciprocidade existente na relação entre dois sujeitos, e pressupõe um reconhecimento dos lugares de um e de outro, além de representações e investimentos afetivos recíprocos. Passos ${ }^{224}$ aponta ainda que o laço filial, sendo um laço de grupo, supõe:

- Que os sentimentos de comunidade, fusionais se estabeleçam entre os membros do laço (que os membros se vejam e se tratem como se fossem próximos ou idênticos, formando um grupo);

- Que os membros do laço o vivam como um sonho, quer dizer, que eles o coloquem à disposição de sua relação seus processos primários;

- Que eles coloquem em comum, inconscientemente, os mitos familiares ligados ao laço, os modelos de funcionamento e outras representações coletivas, como ideais e expectativas recíprocas;

- Que eles sejam dependentes das leis próprias ao seu funcionamento.

Essas pistas permitem compreender que o processo de filiação depende da reciprocidade de investimentos, implícita às relações pais-filhos e que tal processo se inicia muito antes da existência do filho, ou seja, na história e, mesmo na pré-história, de filiação dos pais. É importante ressaltar que os elementos acima mencionados não devem ser entendidos como condições necessárias, sine qua non, para que uma família se configure, mas como elementos que, num a posteriori que põe em jogo uma anterioridade, podem ser encontrados num grupo que se reconheça como uma família constituída. No caso da família homoparental, tendo em vista as diferentes possibilidades de origem (relação heterossexual anterior, adoção, co-parentalidade ou uso de reprodução tecnológica), é possível supor diferentes formas dos membros se instaurarem em posições parentais. Por exemplo, o parceiro de um pai que tenha um filho advindo de relação heterossexual anterior mais dificilmente conseguirá ocupar um lugar de mãe para esse filho, ainda que exerça função mais feminina (ou maternal) em

${ }^{224}$ Idem, ibid. 
sua relação conjugal com o pai, assim como, ao inverso, poderá exercer uma função paterna diante do filho (biológico) do parceiro, colocando-se como um terceiro e interditor simbólico da relação afetiva entre o filho e seu pai. Caso haja ainda um investimento afetivo recíproco entre os membros, tal como citado acima, o qual dependerá sobremaneira do modo como o pai do filho fará a mediação e distribuição econômica-libidinal entre o parceiro e o filho, poderá haver a configuração de um grupo familiar, ainda que cada um dos membros não ocupe todos os lugares e funções parentais tradicionais. O parceiro pode, por exemplo, ser denominado como tio, ocupando um lugar simbólico outro, deixando vago, do ponto de vista fenomenológico, o lugar materno que, por sua vez, pode ser desempenhado pelo pai, apesar disso ocorrer menos frequentemente.

O surgimento das famílias homoparentais, como já afirmado, reabriu uma discussão que tem suscitado polêmicas sobretudo entre os psicanalistas: uma suposta elisão da diferenciação sexual. Boa parte dos argumentos contra a homoparentalidade afirma que, não havendo uma diferenciação sexual entre os pais, os filhos cresceriam sem referências ou com referências distorcidas, o que acarretaria problemas e disfunções de natureza sexual. Essa questão, entretanto, não pode ser tratada de forma determinista, tampouco alarmista. Até porque, do ponto de vista psicanalítico aqui utilizado, sabe-se que toda criança - consanguínea ou não - precisa ser adotada pelos pais como filho e estes, como pais pela criança. É o desejo que circunda as estruturas discursivas de determinada configuração familiar que colocará em jogo os lugares e funções que cada membro desempenha e ocupa em relação a cada um dos membros. Sendo assim, a diferenciação que a criança faz não diz respeito ao sexo necesariamente. É na relação intersubjetiva com cada membro do par conjugal que se faz a distinção das funções simbólicas, distinção esta mais fundamental para a definição dos vários personagens e seus respectivos lugares na estrutura familiar do que a existência de diferença anatômica. Não se verifica o risco, na experiência prática, de a criança chamar de pai uma mulher, ou de mãe, um homem. Um casal homossexual não anula a diferença entre os sexos, pois ela continua a existir na cultura e na sociedade, além do fato de a criança não ficar circunscrita apenas ao universo 
familiar mais próximo; na interação com outras pessoas ela tem oportunidade de se relacionar com ambos os sexos, se o temor for o do isolamento.

Segundo Dubreuil ${ }^{225}$, os temores mais referidos pelos tribunais em relação às famílias homoparentais, dizem respeito a eventuais problemas na identidade sexual da criança, uma vez que seus modelos de inspiração e referência não expressam diferenças sexuais entre si. Segundo esse raciocínio, um modelo único permitiria apenas a identificação a um tipo de sexualidade, e poderia, em muitos casos, assim acreditam, facilitar a orientação homossexual dos filhos e dificultar a integração dos mesmos na sociedade. Sabe-se, entretanto, que esses temores estão repletos de preconceitos e de resistências ao novo que tais famílias representam, haja vista que as identificações não se formam apenas por esse caminho, mas também através do contato com diversos e distintos recursos de aspecto sociocultural, tais como a relação com os demais familiares, com professores, com os pares, com a mídia, em geral, dentre outros.

Ao refletir sobre as diferenças sexuais na homoparentalidade, Parseval $^{226}$ é mais incisiva, no que concerne às resistências feitas a essa modalidade de família. Para ela, o mais importante é que a criança seja recebida por pessoas que a desejem. Os adultos que irão criar a criança devem poder lhe oferecer tanto os recursos para sua sobrevivência quanto um compartilhamento de investimentos e afetos que a humanize, para prosseguir criando o cenário e as contingências de sua própria história. Também para essa autora os fundamentos da parentalidade não estão na diferença anatômica entre os sexos, mas na dimensão simbólica das funções que esses dois adultos constróem junto às demandas da criança. Nesse caso, devem prevalecer as condições já afirmadas de que ela necessita para amadurecer psiquicamente.

De fato, se a diferença anatômica fosse tão fundamental para a instauração das diferentes funções parentais não seria possível considerar as duas funções instaladas em casos de família monoparental, em que só um dos parceiros convive com a criança. $E$ no que se refere à identidade sexual da criança, seria impossível haver um homossexual, caso a identidade sexual dos pais fosse tão determinante da dos filhos, uma vez que a imensa maioria dos homossexuais são frutos de pais heterossexuais. $O$

\footnotetext{
225 DUBREUIL (1998) apud PASSOS (2007), op. cit.

${ }^{226}$ PARSEVAL (1998) apud PASSOS (2007), op. cit.
} 
que se deixa de levar em conta com a ideia de que a inexistência da diferença sexual entre pais é prejudicial à constituição psíquica da criança é a própria posição subjetiva da mesma, ou seja, que os efeitos da estrutura discursiva familiar, além de inconscientes, dependem da maneira como a criança, o sujeito a advir, se posiciona, por sua vez, em relação a essa estrutura "recebida". Em outras palavras, o sujeito não apenas incorpora passivamente os elementos advindos do Outro. Ainda que estes elementos, por sua vez, determinem inconscientemente o sujeito, não invalidam a implicação do eu em suas escolhas, o que lhe permite reconhecer esses elementos como próprios ou negá-los, recalcando, denegando ou foracluindo-os ${ }^{227}$.

Retomando as funções parentais, quando se trata da função materna, isso implica em um cuidado primário que permita à criança ser recebida, acolhida, reconhecida, de modo a que ela possa, a partir daí, assimilar os recursos herdados, transformando-os a cada etapa do seu desenvolvimento. O reconhecimento do bebê implica na formação de um vínculo que será a matriz de todos os outros construídos ao longo de sua trajetória. Nesse caso, o olhar materno instaura e potencializa a condição da criança de investir tanto no outro como parceiro da vida, quanto, ao mesmo tempo, em si mesmo.

A função paterna, por outro lado, deve possibilitar a expansão do mundo afetivo da criança, por meio da inserção de um terceiro elemento na relação da mãe com seu bebê. Essa inserção, ao mesmo tempo em que interdita a dualidade da relação primária, oferece os princípios da lei, com a qual o ser humano faz sua entrada em um mundo simbólico. É possível dizer que o pai tem uma função organizadora no grupo familiar, de modo a contribuir, significativamente, para a negociação das demandas e disponibilidades entre seus membros e para a distribuição dos lugares simbólicos entre eles.

$227 \quad$ As três formas de negação dos conteúdos inconscientes identificadas por Freud, que indicam o tipo de estrutura psíquica do sujeito. O recalque é a negação que define a estrutura neurótica; o perverso é definido pela denegação (ou desmentido) e o psicótico pela foraclusão - tal qual nomeado por Lacan ou repúdio. Cada estrutura irá substituir a fantasia inconsciente negada por uma formação clínica específica: o sintoma, nas neuroses; o fetiche , na perversão e o delírio nas psicoses. (Cf. JULIEN, P. Psicose, perversão e neurose: a leitura de J. Lacan,. RJ: Cia. de Freud, 2004.) 
De acordo com a psicanálise da família, não há nenhuma função que tenha autonomia dentro do grupo, cada uma adquire seu sentido numa relação de interdependência com as demais. As funções de cada membro, em um contexto familiar, designam uma perspectiva instrumental/operacional construída em uma relação de reciprocidade. Os cuidados maternos estão a serviço do bebê, sem os quais ele não consegue criar seus próprios limites enquanto sujeito autônomo em relação a essa mãe. A função paterna, por sua vez, só adquire seus sentidos na articulação com a relação mãe e criança, limitando essa relação.

Fica claro, portanto, que as funções na família criam suas atribuições naquilo que se configura como demanda dos sujeitos. Elas são construídas tendo como referência os lugares e posições que cada membro assume, desde o nascimento, diante do outro e da fantasmática grupal ${ }^{228}$. Partindo dessa perspectiva, é possível deduzir que essas funções não exigem necessariamente a presença de uma diferenciação sexual real anatômica - para que haja um pai e uma mãe.

Uma criança que é criada por sua avó materna e sua mãe pode ser constituída e marcada pela castração simbólica, assim como em um casal heterossexual pode haver a impossibilidade de distinção de papéis, funções simbólicas e gerações, o que a clínica mostra constantemente.

Sendo constituídas pelos investimentos recíprocos do grupo familiar e sustentadas pelas ações do cotidiano, é possível que as crianças busquem afinidades e modelos em outras figuras como tios, avós, padrinhos e madrinhas, caso não haja, em seu círculo mais próximo, figuras que lhe ofereçam as referências necessárias, em determinado momento de seu desenvolvimento. A busca natural de parcerias e modelos identificatórios tem sido uma evidência, que vários autores assinalam, revelando, inclusive, a grande plasticidade e sabedoria das crianças, quando se trata de encontrar saídas, que lhes permitam crescer e amadurecer.

Do ponto de vista de sua origem, é possível dizer que as funções parentais dependem, desde o início, da história do desejo de criar um filho e de como este desejo

\footnotetext{
228 Segundo a Psicanálise de Família, trata-se da fantasia que pertence ao inconsciente familiar, o grande Outro, enquanto lugar simbólico de determinado grupo familiar, ao qual todos os membros da família estão referenciados em suas respectivas posições subjetivas.
} 
é acolhido e partilhado com o parceiro (a). Assim, quando surge a criança, Passos ${ }^{229}$ aponta que é preciso levar em conta a identificação do casal parental com o filho e, especificamente, a disponibilidade e o investimento de cada um, nele. Este processo depende da posição do pai e da mãe em suas cadeias de filiação originárias, ou seja, como foram reconhecidos como filho(a) e como elaboraram as mudanças de posição, ao longo de seus processos de amadurecimento até o momento da criação do filho. Depende também de como um membro parental representa o outro e das atribuições recíprocas assumidas na presença da criança, para que a criança possa reconhecer e distinguir as diferentes funções simbólicas e, constituindo-se como sujeito desejante, poder passar pela castração simbólica do desejo, de modo a estruturar-se psiquicamente como neurótico .

Essas atribuições são sustentadas pelos investimentos afetivos e pela formação dos laços narcísicos e objetais no delineamento da família. Sintetizando, pode-se dizer que as funções parentais se organizam em três sentidos principais, marcados pela reciprocidade: de um membro do casal em relação ao outro; de cada um dos pais em relação à criança e dessa em relação a cada um dos pais.

Enfim, quando se consideram as funções parentais por esses ângulos, vê-se que o mais importante para a constituição psíquica da criança é a qualidade das trocas entre ela e seus pais. Trocas essas que devem se pautar, sobretudo, em uma transparência e verdade sobre a história da família e da origem da criação. Precisam também expressar que a criança foi desejada por ela mesma e não para afastar as frustrações e os lutos dos pais.

Dessa forma, considerando o exposto, é pertinente repetir que a diferenciação sexual de um casal não é um elemento indispensável ao desempenho das funções materna e paterna. Mais do que os signos da sexualidade, são os enunciados simbólicos que diferenciam as posições assumidas pelo casal parental no contexto de uma filiação. Está em jogo, nesse caso, as diretrizes que um e outro membro assume diante da dupla conjugal e do filho (a). É, antes de mais nada, a forma como um casal homossexual decide ter filhos, como procura viabilizar essa decisão e como se oferece a esse filho (a), que constituem os fundamentos da parentalidade e da estrutura do

${ }^{229}$ PASSOS, M. C. - loc.cit. 
grupo familiar. Mais adiante, serão verificados recortes do discurso de sujeitos que vivenciam a experiência da homoparentalidade.

Embora haja a preocupação de alguns psicanalistas a respeito das consequências da homoparentalidade para a saúde psíquica dos filhos, ainda hoje não se têm evidências de problemas psíquicos suscitados, diretamente, por esse modelo de família. É sabido, entretanto, que filhos de casais homossexuais ainda são vistos com muitas resistências e preconceitos, por parte de adultos ou mesmo pelos colegas que têm outro tipo de convivência familiar. Esse ainda é um dos maiores impasses vivido por essas crianças e por seus pais homossexuais, conforme pode ser verificado na recente pesquisa de doutorado em Psicologia Social de $\operatorname{TOLEDO}^{230}$ (2008), sobre a representação de família no discurso de membros de famílias homoparentais.

De um modo geral busca-se um entendimento das diferentes modalidades de família a partir das premissas históricas do patriarcado. A homoparentalidade não foge a esta regra e, nesse sentido, se torna difícil, e às vezes perigoso, o debate que se estabelece em relação a suas especificidades e seu potencial de subjetivação, uma vez que é muito comum sua condenação a priori, por não oferecer um quadro referencial compatível com aquele instituído pelo 'status quo' patriarcal.

Passos $^{231}$ entende que há aí um equívoco, pois, no caso da homoparentalidade, é impossível um ajuste entre modelos; afinal, as relações homoparentais exigem uma configuração de funções e lugares distinta da parentalidade heterossexual.

Quando se trata de processo de filiação, em qualquer tipo de família, é preciso ressaltar, em primeiro plano, as funções que o casal e cada um dos membros, individualmente, exercerá junto à criança, inscrevendo-a e a eles próprios em uma cadeia simbólica. Os primórdios dessa função surgem quando o filho é apenas um desejo e prossegue quando a criança nasce. Há um processamento psíquico dos laços produzidos a partir de investimentos constituídos pelas representações e afetos que circulam reciprocamente entre os membros da inter-relação.

230 TOLEDO, L. C. C. - A família no discurso dos membros de famílias homoparentais. Tese
(Doutorado) IP-USP. São Paulo, 2008 .
231 PASSOS, Maria Consuelo. - 'Homoparentalidade- uma entre outras formas de ser família'. IN: Revista Psicologia Clínica, Rio de Janeiro, v.17, n.2, pp.31-40, 2005. 
Essa conceituação serve para pensar os fundamentos mais universais das funções familiares, que dizem respeito à recepção, ao acolhimento, ao reconhecimento e à inserção da criança em uma cadeia de transmissão psíquica e simbólica. Neste contexto das novas famílias, essas funções possibilitam um espaço plausível da nãodiferenciação sexual real no triângulo familiar.

As referências teórico-ideológicas para pensar essa triangulação não podem ser jamais aquelas da hegemonia do poder paterno, tampouco as fundadas no princípio do gênero e de diferenciação sexual.

Os psicanalistas que se posicionaram em suas publicações contrários à adoção por homossexuais - Irène Théry, assim como Pierre Legendre, por exemplo - acreditam que, do contrário, seria consentir em "privilegiá-los, na medida em que estariam dispensados da obrigação e da responsabilidade de ter o outro sexo para apresentar à criança" $^{232}$. Além disso, temem que o casal homossexual possa apagar a diferença entre os sexos.

Ora, em um casal heterossexual, a impossibilidade de distinguir papéis, funções simbólicas e gerações existe. A existência real dessas diferenciações não é garantia de constituição de um sujeito "saudável". E mais, a diferença simbólica, até o momento restrita a dois gêneros, não precisa estar inscrita na anatomia dos corpos; são funções que podem ser exercidas por quaisquer pessoas.

A família de hoje impõe, no lugar da hegemonia dos papéis e dos lugares fixos, uma maior flexibilidade na constituição de posições e funções dos membros do grupo. Assim, ganha muito mais força a forma como os pais do mesmo sexo, cada um a sua maneira, representa este filho como um outro que "atualiza seu desejo de transmissão e continuidade, investindo-o, portanto, de um afeto fortemente narcísico" (PASSOS ${ }^{233}$, 2005).

Nesse caso, pouco importa se a triangulação é constituída por dois homens e um filho ou por duas mulheres e uma filha, a circulação dos afetos se faz numa circunstância em que a identificação entre os pais e os filhos não exige mais os

\footnotetext{
${ }^{232}$ THÉRY, Irène. e LEGENDRE, Pierre apud PASSOS, M. C. (2005), op. cit.

Estes dois psicanalistas franceses também são citados em ROUDINECO (2003), op. cit.; em UZIEL (2007), op. cit. e em PERELSON (2006) (Cf. Bibliografia) como opositores à adoção de crianças por homossexuais.

${ }^{233}$ PASSOS, M. C. (2005), op. cit.
} 
contornos de antes. Em outras palavras, o jogo especular da triangulação edipiana, no qual a identificação com o igual exigia a presença do diferente, perde a sua força. Parece ganhar mais relevância no jogo entre iguais o processamento psíquico dos desejos dos pais, associado ao re-ordenamento que a criança faz do material percebido. Nesse caso, o filho adquire cada vez mais um estatuto de ordenador de sua herança, herança esta engendrada em um ambiente que o reconhece como autor de sua própria história.

\section{1: PESQUISA SOBRE OS PAPÉIS PARENTAIS COM CASAIS HOMOPARENTAIS.}

Das poucas pesquisas de caráter qualitativo realizadas no Brasil, e mais especificamente em São Paulo, que contemplam a observação ou entrevistas diretamente feitas com os membros de casal homoparental, observam-se resultados reiteradamente apontados para as seguintes questões: ambiguidade na identificação às posições simbólicas, ausência de diferenciação e maior igualdade no desempenho dos papéis parentais, maior flexibilização, menor hierarquia, circulação das lideranças no grupo, relacionada à presença de múltiplas formas de composição familiar e, consequentemente, de formação dos laços afetivos e sociais, o que possibilita distintas referências de autoridade, tanto dentro do grupo como no mundo externo.

Devido à dificuldade em localizar sujeitos que se enquadrassem no objeto de interesse deste trabalho, pela escassez de tempo e o descobrimento das fontes de informação necessárias à localização, serão utilizados alguns dados da pesquisa de Rodriguez e Paiva ${ }^{234}$ que mostra que a ausência de pais dos dois sexos não parece ter incidência sobre o desenvolvimento da identidade sexual e o desenvolvimento psicológico geral das crianças. A situação homoparental mostra o aumento da flexibilização nas relações e papéis sociais de gênero, o que demonstra um maior questionamento de ser feminino e masculino, ou seja, dos constructos ideológicos na

234 RODRIGUEZ, B. C.; PAIVA, M. L. S. C. - Um estudo sobre o exercício da parentalidade em contexto homoparental. Universidade Presbiteriana Mackenzie, São Paulo. Brasil, 2009 
atualidade. Essa flexibilização de papéis a que as autoras se referem também pode ser encontrada em outras configurações familiares atuais.

A pesquisa realizada teve como colaboradores dois casais homoparentais, na faixa etária entre 25 e 40 anos de idade, responsáveis por ao menos uma criança. Em ambos os casos as crianças eram frutos de relacionamentos heterossexuais anteriores e a família vivia junta há pelo menos um ano. O primeiro casal é formado por duas mulheres, com duas filhas, uma de cada cônjuge, e o segundo casal é formado por dois homens, com uma filha biológica de um dos cônjuges. O método da pesquisa foi o clínico-qualitativo, proposto por Turato ${ }^{235}$, sendo que os instrumentos utilizados para a coleta de dados foram a entrevista semi-aberta e o procedimento Desenhos de família com estórias (TRINCA ${ }^{236}$, 1997). Os dados colhidos nos encontros com as famílias forneceram material para reflexão e maiores questionamentos acerca da vivência homoparental.

A pesquisa realizada apresentou alguns aspectos da homoparentalidade, como o sentimento de família, caracterizado pela intimidade, presente em ambos os casais entrevistados. Notou-se também a ênfase em alguns valores na educação dos filhos, como a liberdade de escolha, o respeito pela individualidade de cada um e a integração familiar, inclusive com as famílias de origem.

As pesquisadoras formularam a hipótese de que a ênfase na liberdade de escolha na educação dos filhos poderia estar relacionada ao preconceito vivido por esses casais quando assumiram a homossexualidade e a homoparentalidade. Referiram perceber, no discurso dos casais, uma ênfase na liberdade e no respeito pela liberdade de escolha, ao mesmo tempo em que valorizam a diferença, nesse caso pela homossexualidade, desejando que os filhos internalizem a concepção transmitida de respeito à diversidade.

No exercício da parentalidade, a pesquisa revelou a flexibilidade de papéis, ou seja; os dois parceiros se alternando nas atividades consideradas socialmente como femininas e masculinas. A questão do gênero permeia todos os tipos de configurações familiares, tornando cada vez mais presente a alternância de papéis dentro das diversas organizações familiares.

\footnotetext{
235 TURATO (2003) apud RODRIGUEZ, B. C.; PAIVA, M. L. S. C. loc. cit, 2009.

236 TRINCA (1997) apud RODRIGUEZ, B. C.; PAIVA, M. L. S. C. loc. cit, 2009.
} 
Não há uma hierarquia bem definida, existindo relações mais igualitárias entre todos os membros da família, estando a autoridade parental não colocada de forma objetiva para as crianças. Além disso, esteve muito presente no discurso de ambos os casais a questão do preconceito sofrido por parte das famílias de origem e da sociedade, sendo citada com maior freqüência a escola. A ausência de redes de apoio pareceu ser o fator que causa maior angústia no contexto homoparental, além de dificultar o exercício da parentalidade.

Constatou-se ainda que o casal feminino apresenta uma imagem de família tradicional, indicando que, apesar da aparente aceitação da homoparentalidade, a família é ainda vista por elas tendo o modelo de casal e de família heterossexual como ideal e referencial. Já o casal masculino trouxe a imagem de família homoparental, mostrando maior proximidade com a sexualidade vivida por eles, isto é, uma convergência entre a conjugalidade e a parentalidade homossexual.

As crianças do casal feminino buscam uma maior referência nas suas mães biológicas do que nas parceiras de suas mães. A parentalidade ainda não está bem constituída nesse casal, parecendo mais uma coabitação de duas mães cuidando de duas crianças, cada uma dedicando-se mais a sua filha biológica. Inferiram que a dificuldade em formar um casal parental dever-se-ia não somente ao fato de ser uma família reconstituída, mas também devido à divergência entre a imagem de um casal parental heterossexual e o desejo de viver um relacionamento conjugal homossexual.

Uma das filhas do casal feminino convive com o pai biológico e a outra não tem contato com a figura paterna desde que nasceu. No caso dessa filha que tem contato com o pai, sua mãe compartilha o cuidado com a parceira e o pai da criança. Esse fato reforça a dificuldade que o casal conjugal tem em formar um vínculo parental, já que a menina tende a não enxergar na parceira da mãe uma figura de autoridade. Essa realidade vivida pelo casal é similar a das famílias reconstituídas, onde as crianças são cuidados por vários adultos, isto é, parceiros de seus pais biológicos. Desse modo, algumas crianças demonstram ter dificuldade em aceitar a autoridade dos cônjuges de seus pais, já que para elas a vivência da separação dos pais acaba sendo difícil de ser elaborada. 
No casal homoparental é fundamental pensar o quanto os dois membros se envolvem na adoção, e, posterior à adoção, o nível de interferência e o papel de cada um no cuidado com a criança. Cada membro do casal de homens mostrou-se igualmente envolvido na preocupação com o bem-estar e educação da filha, citando cuidados como terapia e participação das atividades da escola, além de terem recentemente passado por um processo jurídico para conquistar a guarda da criança.

Com eles foi possível perceber melhor aceitação e esclarecimento com relação à homoparentalidade e à própria homossexualidade vivida na relação matrimonial. Os instrumentos utilizados possibilitaram demonstrar o casal parental de homens e os filhos em um contexto de cuidado e afeto, denotando que o exercício da parentalidade é efetuado pelos dois e também de modo mais integrado, apesar do pouco tempo de convívio.

O discurso do casal feminino explicita a importância da aceitação através da diferença, enfatizando o desejo de aceitação, o que não foi observado no casal masculino. Essa necessidade do casal feminino encontrar sua identidade na diferença dá elementos a suas filhas para buscar suas identidades também na diferença. Durante a entrevista, elas relataram que desejam para suas filhas um casamento heterossexual. As autoras inferiram que as duas projetam nas meninas aquilo que elas não conseguiram realizar, isto é, atender ao desejo da própria família de origem de formarem um casal heterossexual, bem como atender à própria imagem de família.

Percebeu-se, ainda, no que se referia à educação dos filhos, a ênfase na afetividade e no diálogo. Os casais aparentaram manter relações de muito afeto e conversa com os filhos, nas quais permitem apresentação e discussão de opiniões, corroborando dados de estudos anteriores que mostraram que as famílias homoparentais configuram um contexto familiar baseado nos laços de afeto.

Os casais participantes, por estarem há pouco tempo juntos, ainda se organizavam enquanto família, adaptando-se às necessidades e dificuldades que vão surgindo com a convivência. Portanto, é importante ressaltar que sempre existe a possibilidade de desenvolvimento de mudanças nas relações entre todos os membros e especialmente no exercício da parentalidade. 


\section{2: IDENTIDADE SEXUAL, PATERNIDADE E MATERNIDADE.}

Dentre todos os requisitos e condições para a parentalidade homossexual, sejam legais, jurídicos, políticos e até mesmo econômicos, cabe aqui ressaltar o aspecto psíquico. O que move um sujeito em direção a ter e criar um filho é o desejo de criança que, desde cedo, pode ou não surgir num sujeito. Em algum momento de sua história singular, um sujeito acredita-se poder ser pai ou mãe. Como será visto, este desejo se constitui de forma independente do tipo de escolha de objeto sexual que um sujeito possua. Em outras palavras, o desejo de filho não é exclusivo da heterossexualidade.

Norteados por tais colocações, será abordado a seguir o discurso de sujeitos que conjugam a experiência de ser pai ou mãe com a sua identidade homossexual.

\subsection{1: A Paternidade Homossexual.}

É perceptível que as reformulações da vivência da paternidade e de sua representação acompanharam a ruptura gradativa, que se intensificou na alta burguesia, das dimensões do público e do privado. Ao papel masculino, vinculado ao papel paterno, foram atribuídas as funções de circular no mundo econômico, nos trâmites administrativos, nas articulações trabalhistas, ou seja, nas relações sociais que se davam na cena pública.

Uma pesquisa realizada em 2002, com o objetivo de conhecer o discurso do homem sobre paternidade e as possíveis articulações desta com a masculinidade reafirmou o já sabido: mostrava que, no imaginário social, ser pai é referência apenas para a masculinidade do homem casado, a paternidade é apontada como elemento fundamental para aquele que passa pelo matrimônio (COSTA, 2002 ${ }^{237}$ ). Essa pesquisa reafirma 0 fato da paternidade ter sido construída numa vinculação direta com o

237 COSTA, R.G. (2002) apud DINIZ, A.G.R.; BORGES, C.A.M. "Possíveis Interlocuções entre Parentesco e Identidade Sexual: Paternidade vivenciada por Homens Homo/Bisexuais". In GROSSI, M.P. et. al. (orgs.) - Conjugalidades, Parentalidades e Identidades Lésbicas, Gays e Travestis. RJ: Garamond, 2007. (Pp. 253-274). 
matrimônio e, consequentemente, com a heterossexualidade. Da mesma forma que a esterilidade do homem está ligada à impotência sexual, 'ter filhos' está diretamente associado à virilidade heterossexual. (COSTA $\left.{ }^{238}, 2002\right)$.

A bibliografia que discorre especificamente acerca da paternidade homossexual busca compreender as tendências que tais estudos desenvolvem no processo de análise desse fenômeno e as possíveis diferenças que existem entre as criações de filhos por homossexuais e heterossexuais. Em um levantamento, efetuado em 2003, dos argumentos que vão contra e a favor da paternidade/maternidade homossexual, verificaram-se que os posicionamentos desfavoráveis alicerçam-se na concepção burguesa da família e na hipótese da homossexualidade configurar-se em patologia ou anomalia. Em contrapartida, os discursos favoráveis buscam tecer uma crítica histórica à patologização da homossexualidade, compreendendo a família e a sexualidade como instituições e dimensões construídas sócio-historicamente.

Outro dado importante relacionado à parentalidade homossexual é que, geralmente, essas famílias foram encaradas como monoparentais, já que não se reconhecia um dos parceiros, nem judicialmente, nem socialmente. A tendência em isolar a variável 'orientação sexual' no processo de análise e interpretação de famílias homparentais ainda representa um ideário heterossexista e uma representação de que homossexuais prejudicariam seus filhos (UZIEL $\left.{ }^{239}, 2004\right)$.

Em uma pesquisa apresentada por Tarnovski ${ }^{240}$ sobre as representações acerca da paternidade em homens homossexuais verificou-se que os sujeitos afirmavam, entre outras coisas, que não se sentiam diferentes dos pais heterossexuais, podendo, da mesma forma, criar filhos próprios. Apontou-se também uma necessidade em se pensar a identidade sexual para além de elementos ligados à sexualidade, buscando compreender que esta identidade define, muitas vezes, espaços de participação e identidades políticas (grifos nossos)

Diniz e Borges ${ }^{241}$ demonstram que existem muitas representações negativas acerca da paternidade exercida por homossexuais. Ainda existe a fantasia no

\footnotetext{
${ }^{238}$ COSTA, R.G. (2002) apud DINIZ, A.G.R.; BORGES, C.A.M., op. cit.

${ }^{239}$ UZIEL (2004) apud DINIZ e BORGES, op. cit.

240 TARNOVSKI (2004) apud DINIZ e BORGES, op. cit.

${ }^{241}$ DINIZ e BORGES, op. cit.
} 
imaginário social de que o pai irá abusar de seus filhos e que, por serem exacerbadamente sexualizados, irão transmitir sua sexualidade e/ou orientação sexual aos filhos e filhas (RAMIRES, $1997^{242}$ ).

Ao solicitar sujeitos que falassem de sua experiência em ser pai, na condição de homo/bissexual, Diniz e Borges ${ }^{243}$ apontam duas grandes tendências percebidas nos discursos colhidos: a) respostas baseadas no pressuposto de que a paternidade e a orientação sexual são dimensões independentes; b) respostas construídas na tentativa de relacionar essas duas dimensões.

Como existe uma série de representações que apontam para a paternidade como uma vivência restrita aos heterossexuais e que os homo/bissexuais irão prejudicar o desenvolvimento de seus filhos, esses homens possivelmente buscam vivenciar a função de pai separadamente das experiências sexuais, buscando encontrar formas de garantir que a sexualidade não interfira na criação de seus filhos, conforme citação a seguir:

São campos totalmente diferentes, a sexualidade e a paternidade [...] Não é minha sexualidade que modifica o exercício da paternidade (P., 31 anos).

Não permito que os personagens se confundam, ou se misturem (R., 37 anos).

Outro elemento ressaltado pelos autores nas respostas dos sujeitos, na primeira tendência, é o dizer que a experiência [da paternidade homossexual] é "normal", discurso esse possivelmente articulado à tentativa de manter-se numa posição de normalidade na sociedade, buscando, mais uma vez, "proteger-se" de discursos patologizadores, e apontando para uma possível estratégia de enfrentamento de práticas segregadoras que a sociedade produziu para combater a homossexualidade.

\footnotetext{
242 RAMIRES (1997) apud DINIZ e BORGES, op. cit.

${ }^{243}$ DINIZ e BORGES, op. cit.
} 
O desejo de ser pai pode também estar vinculado ao ideário patriarcal que reproduz um modelo hegemônico de vida associado à constituição familiar.

Nas respostas que tendem a refletir e articular as dimensões paterna e de orientação sexual, foi perceptível um apontamento para a experiência paterna na condição de homo/bissexual como uma vivência difícil, complicada e conturbada. Nestas respostas, que evidenciaram o surgimento de conflitos, os sujeitos narraram suas experiências, geralmente, entrecruzando estes dois elementos: sua orientação sexual e sua condição de pai.

Neste sentido, foi encontrada, também, uma considerável preocupação com o futuro dos filhos, dimensionando as possíveis consequências que estes podem enfrentar em ter um pai homossexual.

Difícil (a experiência de ser pai gay). Maritalmente, a função de pai é um grande desafio. Pai gay ganha um acréscimo significativo em termos de desafio [...] (A., 61 anos)

Não é uma experiência fácil, porque você não pode agir naturalmente com sua sexualidade como agem os heterossexuais, não é? $E$ nunca sabemos se nossos filhos vão nos aceitar, pra quem decide contar...(V., 38 anos).

Pode-se perceber, com estes fragmentos, que o papel parental, de pai, e a identidade sexual, para tais sujeitos, encontram-se em relação de conflito, principalmente por se colocarem sempre em relação à heterossexualidade. A homossexualidade, enquanto significante da identidade do sujeito, parece sobrepor-se ao papel parental, que parece ficar em desvalia, quando comparado ao desempenho do mesmo pelos heterossexuais. Os sujeitos parecem tem dúvidas quanto à forma de transmitirão filho a disjunção entre sua própria e particular sexualidade e seu papel parental, com se aquela interferisse no desempenho de sua autoridade parental. Além disso, a fusão entre função e papel parental é evidente, ainda que se discrimine entre o lugar de pai e de marido, ou seja, parentalidade disjunta da conjugalidade. Sabemos, no entanto, a partir de nossa experiência clínica, que tal dificuldade em transmitir essa 
separação de lugares é também bastante frequente em pais heterossexuais com seus filhos. Assim, o temor à homofobia, muitas vezes internalizado e voltado contra si, parece aumentar a angústia frente à parentalidade nos sujeitos homossexuais.

Alguns sujeitos apresentaram experiências negativas da paternidade, em função de outros elementos de suas vidas. Segundo esses sujeitos, a paternidade não é (ou não tem sido) uma experiência agradável, pelo distanciamento dos filhos, por problemas com a mãe do filho ou por falta de identificação com o papel de pai e desconhecimento da função paterna.

[...] é um pouco complicado. Quando me casei achei que minha atração por homens passaria. Mas não passou. Agora é complicado pois não deve ser fácil para uma pessoa ver o pai como um gay. (E., 41 anos)

[...] foi a experiência mais ruim que já tive. Tive muitos problemas com a mãe da minha filha e com isso não pude ter a chance de ser pai por completo. (D., 33anos)

Dentre as dificuldades apresentadas pelos sujeitos, as mais citadas foram: a) o preconceito e a discriminação em relação à homossexualidade e ao papel do pai exercido por esta orientação sexual; b) o distanciamento dos filhos, oriundo da tutela dos filhos ser aferida, tanto socialmente, quando juridicamente, à mulher e; c) a falta de identificação e/ou preparo para exercer a função (imaginária, no caso) de pai, ou seja, o papel de pai ${ }^{244}$.

Quanto às possibilidades apresentadas pelos sujeitos da pesquisa, proporcionadas pela experiência de ser pai e gay, pôde-se perceber uma importante característica presentes na vivência da paternidade de homens gays: o contato com a diversidade ao qual a criança é submetida, e não somente em relação à diversidade de identidade sexual.

\footnotetext{
244 Ressaltamos aqui a importância de diferenciar, como já demonstrado em outro momento deste trabalho, o estatuto do pai real, simbólico e imaginário. Nesta pesquisa, trata-se, principalmente, do papel social de pai, o qual se equivale ao pai imaginário, ou seja, o sujeito que encarna a imagem do pai com todos os atributos que a cultura e o senso comum determinam para tal papel.
} 
Acho que oportunizo ao meu filho conviver com a divrsidade de uma forma absolutamente normal. Não me sinto constrangido por isso e ele, cada vez mais, dá demonstrações de lidar com esta informação com equilíbrio. (J., 38 anos)

[...] sabemos como educar sem formar pessoas brutas ou delicadas demais. (R., 40 anos)

Quanto à possibilidade em se conquistar reconhecimento social, atributo que, segundo os sujeitos, a paternidade confere ao homem, vários sujeitos afirmaram que, após o alcance da paternidade, suas vidas mudaram profundamente, e que alcançaram um maior reconhecimento social e foram mais "bem vistos" pelos amigos e conhecidos.

Ser pai para mim está sendo maravilhoso, estou feliz, sua vida muda automaticamente para melhor. Quanto ao fato de ser gay [...] passei a ser mais respeitado pela sociedade. (J., 42 anos)

Conforme percebido nas citações acima, a construção da paternidade está estreitamente vinculada às noções de masculinidade. Ainda que de formas diferentes para sujeitos diferentes, ser pai é aumentar as características definidoras da masculinidade (TARNOVSKI ${ }^{245}$, 2004). Não tendo o mesmo grau de vinculação que a maternidade tem com a feminilidade, a paternidade constitui elemento importante para a construção de uma identidade masculina. Conforme se percebe na história, o exercício do pai era de fundamental importância para a existência da família, já que este papel constitui um dos tripés da família nuclear burguesa. Momento histórico de ascensão da masculinidade, em que o homem, por receio em misturar-se com as características femininas e homossexuais, definiu uma série de características específicas para se distinguir de "seus inferiores". (SILVA $\left.{ }^{246}, 2000\right)$.

\footnotetext{
${ }^{245}$ Idem, ibid.

${ }^{246}$ SILVA (2000) apud DINIZ E BORGES (2007), op. cit.
} 
Ocorreu apontamento de sentimentos como amor, afeto, atenção e comportamentos, tais como cuidado e carinho, todos vinculados à paternidade (grifos nossos). Historicamente, essas características foram atribuídas à mulher e, consequentemente, ao papel da mãe. Contudo, identificou-se entre os participantes dos grupos focais, e entre os respondentes do questionário uma preocupação em dividir essas tarefas com a mulher, estando mais próximos dos filhos, participando das tarefas de cuidar e educar. Tal fato pode ser relacionado ao que vários autores denominam de aparecimento de um "novo pai", fenômeno este que se intensificou nas últimas décadas.

Sempre amei minhas filhas como elas são, e muito embora elas tenham tido inicialmente um choque, depois tudo se ajeitou com a afetividade, respeito e aceitação mútua. ( $F ., 41$ anos)

[...] todo processo de homofobia que ela (a mãe do filho) colocasse na cabeça dele, o meu contra seria dar muito amor né, muito amor, muito carinho, muita atenção, até chegar o ponto que ela perceberia e ele perceberia a diferença e foi o que aconteceu, deu muito certo [...]. (V., 38 anos).

Conclui-se, a partir dessas citações, que a paternidade tem se construído de forma diferenciada, apostando mais em uma relação menos distanciada do filho. De certa forma, são homens que romperam com os padrões rígidos de masculinidade na sociedade, muito provavelmente em função da assunção de sua identidade homossexual ou bissexual. Assim, suas vivências estão marcadas por relações internas e externas mais flexíveis e dialogadas de gênero, divisão mais justa das tarefas da casa e do cuidado com as crianças.

Por mais que estejamos falando de mudanças no que concerne à definição de família e nas novas exigências sobre o desempenho parental, vê-se que a distinção de gênero determinando atributos qualificados para a função de "cuidador/educador" permanece, no entanto. A mobilidade dos atributos femininos e masculinos pode ser 
aproveitada. "O pai deve mudar mais do que a mãe porque os valores modernos para ser 'bom pai/ boa mãe' são, sobretudo, (socialmente) femininos” (UZIEL $\left.{ }^{247}, 2007\right)$.

Brito248 afirma que três seriam as causas responsáveis por se localizar ainda na mãe a maior responsabilidade sobre os filhos. "A primeira configura-se no contexto social representado por instituições como hospitais e escolas, entre outros, que valorizam sempre a figura da mãe. (...) A segunda causa de atribuição (...) concretiza-se quando se acena com a argumentação de que faz parte de um componente inato das mulheres saber cuidar dos filhos - razão comumente evocada pelos homens que, por identificação com o desempenho de suas mães no lar, atribuem à mulher um jeito mais apropriado, ou especial, para lidar com as crianças. Por último, a autora identifica as causas legais que dão prevalência à mulher para o cuidado da prole e conferem aos pais um papel secundário".

Como visto, a paternidade homossexual vem desestabilizar as divisões rígidas entre os papéis de gênero, tornando as relações mais flexíveis e dialogadas, mas sem que por isso haja um conflito interno aos sujeitos homoparentais em relação à sua identidade de gênero.

\subsection{2: Maternidade Homossexual.}

Quanto à maternidade em um casal de lésbicas, uma outra pesquisa ${ }^{249}$ apontou a dificuldade em localizar o lugar simbólico da parceira da mãe biológica. Não existem papéis predefinidos nem tampouco um modelo a seguir para ela. Na medida em que o casal parental é composto por duas mulheres, a distribuição de tarefas e cuidados não corresponde à clássica divisão de gêneros. Desta forma, para nenhum membro da família está claro o que é que se deve fazer ou o que se pode esperar da 'outra

\footnotetext{
${ }^{247}$ UZIEL, A.P. (2007) Homossexualidade e Adoção. RJ: Garamond, 2007.

248 BRITO (2000) apud UZIEL, A.P. (2007), op. cit.

249 HERRERA, F. - 'A Outra Mamãe': Mães Não Biológicas no Casal Lésbico (Tradução Minha De "La Outra Mamá: Madres no biológicas en la Pareja Lésbica”) IN: GROSSI, M.P.; MELLO, L.; UZIEL, A.P. (orgs.) - Conjugalidades, Parentalidades e Identidades Lésbicas, Gays e Travestis. RJ: Garamond, 2004, (Pp. $213-231$ ).
} 
mamãe'. As relações entre todos os atores envolvidos vão se constituindo e negociando ao longo do tempo e do convívio cotidiano.

A parceira da mãe biológica pode assumir distintos níveis de compromisso e distintos papéis com respeito ao ou aos filho(s). Ela pode ou não considerar-se mãe dos filhos de sua companheira. Curiosamente, sentir-se mãe não tem uma relação direta com a responsabilidade que se assuma nos cuidados. Há mulheres que sem participar ativamente dos cuidados e da criação das crianças se identificam com o papel de mãe, quer seja como a 'outra mamãe', a 'segunda mãe' ou mãe a secas. A pesquisa, realizada com casais de mulheres do Chile, mostra o caso de $\mathrm{D}$. que vive com sua parceira C. e a filha de 20 anos desta. D. afirma que 'se sente mãe', ainda quando sua tarefa se limita a aconselhar de vez em quando a filha de C. No outro extremo, K., que está envolvida ativamente nos cuidados relacionados com Di., filho biológico de três anos de B., sustenta que ela não se considera mãe do menino.

Ao que parece, é mais fácil para as mulheres que planejaram uma maternidade em conjunto com sua parceira, sentirem-se mães. G. afirma que se ela e sua parceira tivessem filhos juntas, ela seria 'a outra mamãe'. Já de acordo com O., E., sua exparceira, conquistou os direitos de ser mãe de seus filhos. O. sustenta:

"além disso a E. assumiu meus filhos desde sempre, os desejou, os amou muitíssimo e foi uma segunda mãe desde o primeiro momento".

As mulheres que formam casal com mulheres que foram mães em uma relação heterossexual anterior costumam não vivenciar a gravidez, o nascimento e os primeiros momentos da criança. Isto pode derivar em que lhes seja mais difícil sentirem-se mães. A outra parceira não costuma se considerar mãe quando formou parceria com uma mulher com filhos já maiores.

Outras entrevistadas não se identificavam com o papel (social, portanto imaginário) de mãe e, portanto, provavelmente não sustentavam uma função simbólica parental de mãe ou de pai. Diziam que eram a tia, a amiga ou a namorada da mamãe. $P$. assinala que ela e sua companheira seriam as pessoas ideais para educar $Y$., a filha de sua parceira. Todavia afirma: "não sou a 'outra mamãe' ou a 'segunda mamãe' ou 
sei lá o quê". Em seguida, sustenta: "eu sou a companheira de sua mamãe, sou a parceira de sua mamãe, a namorada de sua mamãe. Mas ninguém pode apropriar-se dos filhos alheios". Percebe-se, neste caso, a ambiguidade da posição assumida, visto que o sujeito demonstra ter intenção em participar da educação da filha de sua parceira - o que implicaria ocupar uma posição e função parental -, mas coloca-se apenas num lugar de conjugalidade. O que tal sujeito aponta é a sua dificuldade interna em saber qual lugar parental poderia ocupar nessa configuração familiar, ou ainda, se é capaz de ocupar um lugar de função paterna, já que sua parceira ocuparia a função materna “não sou a 'outra mamãe' ou a 'segunda mamãe”' - e visto que o sujeito é uma mulher. As funções parentais muito provavelmente, para este sujeito, ainda estão coladas imaginariamente - à realidade anatômica, ao sexo biológico.

K. tem um discurso ambivalente a respeito de sua relação com $\mathrm{Di}$, o filho de sua parceira. Por um lado, afirma que Di. tem somente uma mãe e ela é a tia. Todavia, quando fala dele, diz 'temos um filho', sobretudo quando fala da situação econômica, já que ela sustenta (economicamente) a criança. Neste caso, apesar da ambiguidade ainda presente, K. já se coloca num lugar e função parental junto ao filho, por colocá-lo neste lugar em seu discurso - 'temos um filho'-, ainda que relacionado ao aspecto econômico (mas não só), ao papel de provedor, o qual tradicionalmente se atribui à figura masculina, nas famílias nucleares tradicionais.

Entre as mulheres entrevistadas, alguns dos elementos que estão em jogo para que a parceira da mãe biológica se sinta mãe - ou que ocupe simbolicamente um lugar e função parental - são: 1) o haver participado da vida da criança desde o início; 2) haver participado ativamente na criação e nos cuidados da criança e 3) o reconhecimento da mãe biológica e outros familiares. Estes fatores podem pesar distintamente em cada mulher e em cada família. Por exemplo, para L., o lugar de mãe pode alcançar-se através da dedicação e dos cuidados, enquanto que para K., as práticas cotidianas não fazem dela mãe.

Para Herrera ${ }^{250}$, cuja pesquisa foi interpretada sob abordagem socioantropológica, há duas posições: a das mulheres que pensam que a maternidade pode ser atribuição de uma só mulher e as que estimam que é possível que uma

\footnotetext{
${ }^{250}$ HERRERA, F. (2004), loc. cit.
} 
criança tenha duas mães. As primeiras põem o acento no biológico, há uma só mãe pois há uma só progenitora. As segundas põem o acento no social, podem haver duas mães pois podem haver duas mulheres que compartilham os cuidados e os desvelos da maternidade.

Sob o aspecto psicanalítico, pode-se dizer que as duas posições encontradas são: 1.) a dos sujeitos que internamente vinculam imaginariamente as funções parentais - paterna e materna - à realidade anatômica e 2.) a dos sujeitos que, de alguma maneira, conseguem desvincular as funções e o sexo biológico, e se colocam num lugar parental, mais frequentemente num lugar terceiro, visto que suas parceiras mantém-se no lugar de mãe, por serem a mãe biológica, ainda que denominem tais lugares com distintos significantes, 'a tia', 'a outra mamãe', dentre outros.

\subsection{3: A Desproteção Legal.}

Um importante aspecto com implicações em todo nível, apontado por Herrera, é a falta de reconhecimento legal do vínculo da 'outra mamãe' e o filho. As consequências disso são profundas não só para ela mas também para a criança, a parceira e para a família em seu conjunto. Entre todas as coisas, se o filho está doente provavelmente a 'outra mãe' não poderá vê-lo no hospital, tampouco poderá tomar decisões com respeito à saúde dele. Além disso, será mais difícil para ela herdar bens para seu filho. Em um caso extremo, não poderá fazer-se cargo de seu filho se a mãe biológica falece ou os abandona. Em uma eventual separação do casal, todos os direitos são detidos pela mãe biológica ou legal. A criança tampouco poderá estar inscrita na estrutura de parentesco de sua segunda mãe. Seus avós não terão direitos e obrigações em relação a ele. Finalmente, a falta de reconhecimento legal torna mais difícil a aceitação social.

A preocupação pela desproteção legal está bem presente nas mulheres que já são mães em casal. L. e C. (casal de Barcelona) é um exemplo. L. manifesta uma profunda inquietude pelos direitos legais de seu filho e uma impotência por não poder protegê-lo em caso de falecimento de C., a mãe biológica e legal da criança. 
Em Barcelona, as 'outras mamães' sofriam a impotência de não poder ser mães legais em casal ${ }^{251}$. A situação que vivia a mãe não biológica ou não legal da criança era um ponto que preocupava e 'tirava o sono' das lésbicas catalãs que eram mães e das que haviam planejado a maternidade em casal. A ausência de reconhecimento legal do vínculo da mãe e seu filho era algo que se vivia como uma profunda injustiça e com muita impotência. Este era considerado um dos temas legais pendentes mais importantes. Desta forma, foi um tópico que surgiu em todas as entrevistas e reuniões das quais a autora participou em Barcelona.

As entrevistadas percebiam que a desproteção legal de uma das mães era prejudicial não só para a mãe de fato, mas também para toda a família. Esta falta de reconhecimento legal e, muitas vezes, social, se traduzia também em problemas na vida cotidiana. Por exemplo, M. afirmava que se seu filho se adoentava, para ela era difícil pedir dias livres do trabalho para cuidá-lo. Isto só podia ser feito por N., que é a mãe biológica de P. e a quem, em seu trabalho, viram-na grávida. De toda forma, M. muitas vezes necessita de dias livres para cuidar de seu filho:

"então tenho que pedir uma hora, mas tampouco posso dizer que é para cuidar de meu filho porque se supõe que não tenho filhos, não é? Com o diretor do centro, se supõe que não tenho filhos".

Uma alternativa de garantia de alguns direitos que está sendo explorada por C. é a de fazer um testamento onde diga que quer que L. tome conta de Mi. em caso de falecimento da primeira.

Os casais de mulheres entrevistados inventavam formas de suavizar ou matizar a posição de desamparo em que se encontrava uma delas com respeito a sua maternidade. E é assim quando surgem temas como o impedimento legal de que os filhos em comum levem os sobrenomes de ambas, ou que a mãe biológica nomeie

\footnotetext{
$251 \quad$ A seguinte informação está baseada no trabalho de campo que a autora realizou em Barcelona nos anos 2001 e 2002. Atualmente a situação das lésbicas catalãs mudou. $\mathrm{Na}$ Espanha aprovou-se a lei (Julio 2005) pela que se modifica o Código Civil em matéria de direito a contrair matrimônio. Com isto se ampliam os direitos dos casais heterossexuais aos casais homossexuais. Isto é, um casal de mulheres poderia adotar conjuntamente um filho. (Cf. HERRERA, F., op. cit.)
} 
como tutora da criança a sua parceira. Assim, fazem um testamento onde se estabelece quem tomará conta da criança em caso de morte da mãe biológica.

Que os filhos levem o sobrenome de suas duas mães, não passa necessariamente pelo reconhecimento da maternidade da mãe não legal e a figura da 'tutora' só é validada quando a mãe biológica se ausenta temporalmente ou está enferma.

Borneman ${ }^{252}$ comenta o quanto o Estado e sua lei - que são o poder institucional mais forte de nosso mundo contemporâneo com capacidade para outorgar direitos e privilégios - negam às lésbicas e gays uma necessidade humana fundamental: o cuidar e ser cuidado.

O reconhecimento legal pode facilitar ou abrir o caminho ao reconhecimento social. Obter a legalidade é uma maneira de validar a 'normalidade' da família. A falta de legalidade do vínculo entre a 'outra mamãe' e o filho é um fator que contribui à resistência a aceitar a maternidade da 'outra mamãe' por parte de seus familiares. Os avós e tios evitam considerar a criança como neto ou sobrinho se o vínculo entre a mãe e o filho não está respaldado legalmente. Os familiares são reticentes a se apegarem afetivamente com uma criança que legalmente não pertence à família e por isso pode ser separada dela a qualquer momento.

Em alguns estados dos Estados Unidos se reconhecem os direitos de adoção do segundo pai ou mãe. Por exemplo, em 1992 no estado de Nova York, criou-se um precedente legal quando uma juíza outorgou direitos de adoção à companheira da mãe de um menino chamado Evan. A juíza reconheceu que uma criança com dois pais tem acesso a importantes benefícios financeiros, práticos e emocionais que não estão ao alcance de uma criança com um só pai ou mãe. No Brasil, as decisões judiciais a favor do registro da criança em nome de ambos parceiros ocorrem de acordo com as jurisprudências locais. Recentemente, decisões judiciais nos estados de Santa Catarina e Rio Grande do Sul autorizaram o registro da criança em nome das duas mãe. Em matéria da Folha de São Paulo ${ }^{253}$, há dois meses da data da publicação, o Supremo Tribunal de Justiça (STJ) reconheceu que casais homossexuais têm o direito de adotar,

\footnotetext{
252 BONEMAN (1997) apud HERRERA, F., op. cit.

${ }^{253}$ FOLHA DE SÃO PAULO - "Maioria é contra adoção por casal gay"- Matéria publicada em 4 de junho de 2010, Caderno 'Cotidiano', p. C1, assinada por Cláudia Collucci. SP: 2010.
} 
porém a lei ainda preconiza que o registro seja feito apenas em nome de um dos requerentes, ou seja, apenas um dos parceiros.

A legalização dos direitos de custódia do segundo pai ou mãe representam uma importante validação pública da possibilidade que a paternidade e a maternidade saiam das fronteiras da biologia. Uma vez que os laços entre a mãe não biológica e seus filhos estão legalmente validados, estudos citados por Herrera ${ }^{254}$ apontam uma mudança de atitudes por parte de seus familiares.

Um aspecto importante que deixa entrever um destes estudo é o de que a maternidade não implica só a relação entre a mãe e o filho, mas também a inscrição do filho em uma estrutura de parentesco que inclui avós e avôs, tios e tias, primos e primas. Quando se reconhece legalmente o vínculo entre a mãe não biológica e seu filho, não só se entregam direitos e obrigações à mãe, mas também se associa legalmente a criança com toda a sua família. Dessa forma, a lei garantiria, por sua vez, a relação da 'outra mãe' com seu filho e o vínculo dos avós com seu neto.

Muitas vezes a assunção de uma posição subjetiva - colocar-se no lugar de mãe ou de pai - passa primeiramente por uma demanda de reconhecimento judicial e/ou social de uma instância Outra que, para o sujeito, o autoriza a tomar tal posição. Esse Outro funcionaria como o Outro da lei, para o sujeito homossexual, que dela demandaria a resposta ao enigma do desejo do Outro: 'o que quer de mim?'.

\subsection{4: Buscando o Reconhecimento Social.}

A combinação de uma identidade sexual marginal - lésbica - com uma tradicional - mãe - e a falta de reconhecimento legal fazem com que a legitimidade social das 'outras mães' seja frágil. Elas e suas parceiras devem criar estratégias para lograr validar seus papéis de mães. Qualquer que seja seu papel dentro dos cuidados do filho biológico de sua parceira, a 'outra mãe' ou a 'tia' desenvolve estratégias para legitimar sua participação na criação, seu vínculo com a criança e seu lugar dentro da família.

\footnotetext{
${ }^{254}$ HERRERA, F. (2004), loc. cit.
} 
O estudo de Hecquembourg e Farrell ${ }^{255}$ assinala que mesmo quando uma mulher reclama para si a identidade de mãe, a validade desta dependerá das respostas e da legitimidade que lhe atribuam seus familiares e pessoas mais próximas. A dificuldade para construir e apresentar esta identidade será ainda maior para a mãe não biológica. Por exemplo, L. se sente questionada em seu papel de mamãe pela mãe de C., que uma vez comentou ao vê-la chegar em sua casa com Mi. nos braços: 'e esta se acha a mamãe!'.

A mãe biológica exerce um papel ativo na legitimação da relação de sua parceira com o filho. C. luta para que sua família de origem reconheça em L. 'outra mãe' de Mi. A teoria lacaniana afirma que o lugar do pai é designado a partir do discurso da mãe, que dirige seu desejo a esse lugar terceiro para além de sua relação imaginária de completude narcísica com a criança. (LACAN, 1999²56). A luta de L. por reconhecimento pode simbolizar a busca de um significante que possa fazer a suplência da função paterna, do significante Nome-do-pai. Percebe-se que, muitas vezes, os sujeitos homossexuais lançam mão de recursos próprios e singulares para tal operação. No entanto, a ciência da importância do reconhecimento do Outro para a inserção na cadeia simbólica e de parentesco faz com que os membros do grupo homoparental continuem buscando no Outro, na cultura, o significante socialmente reconhecido e aceito que lhes dê um lugar nessa nova ordem, inclusive com direitos e deveres constituídos. Para a assunção dos papéis e das funções parentais do ponto de vista psíquico, no entanto, requer-se um outro trabalho - singular e subjetivo - de elaboração, o qual mobilizará o lugar que o sujeito ocupa em sua fantasia fundamental e em sua própria história subjetiva.

No aspecto sócio-jurídico, a mãe que pariu pode exigir o reconhecimento da maternidade através da biologia. Mas o reclame à maternidade da parceira, que não tenha parido e não tem vínculos biológicos com a criança, é socialmente construído e depende da validação das pessoas que a rodeiam: sua parceira, seu filho, seus familiares, as autoridades legais, companheiros de trabalho, etc.

\footnotetext{
${ }^{255}$ HECQUEMBOURG e FARRELL apud HERRERA, F. (2004), loc. cit.

${ }^{256}$ LACAN, J. - O Seminário, livro 5: as formações do inconsciente. (1957-58). [Tradução de Vera Ribeiro; revisão de Marcus André Vieira]. - RJ: Jorge Zahar, 1999.
} 
Donovan $^{257}$ identifica duas formas nas quais as responsabilidades e lugares dos familiares são reforçados: 1) mediante os nomes, como disse cada um dos membros e 2) mediante os cuidados que cada membro leva a cabo. As 'outras mães' entrevistadas acrescentam duas outras estratégias para legitimar seu lugar na estrutura parental e familiar: tentam participar o máximo possível na concepção do filho e diminuem o perfil ao biológico como principal fundamento das relações de parentesco.

Quanto à primeira forma, os nomes, Donovan ${ }^{258}$ assinala que o nomear as pessoas nas famílias é uma tarefa essencial para dar forma ao grupo enquanto família. A nomeação, além de fundar lugares simbólicos e abrir possibilidades de inscrição do sujeito numa linhagem histórica, é uma das funções do pai simbólico, o Nome-do-Pai, segundo Lacan. Nos casais de lésbicas, observou-se que a opção da terminologia utilizada reflete o modelo de maternidade escolhido, por exemplo, se é compartilhado ou não. Para responder à pergunta de como a criança deve referir-se a suas duas mães existe entre as lésbicas uma grande quantidade de alternativas. Entretanto esta não é uma preocupação importante apontada pela entrevistadas. Ainda que não tenha sido considerada, depreende-se disso que o lugar a ser designado à parceira da mãe depende do lugar que a mãe biólogica - ou aquela que ocupar primeiramente esse lugar simbólico - oferece à outra parceira.

O estudo de Herrera ${ }^{259}$ mostra que a preocupação pelos nomes estará mais presente nas entrevistadas em Barcelona. As lésbicas catalãs mostram uma grande variedade de formas de chamar às duas mães, mas na maioria dos casos se trata de distintas formas de dizer 'mamãe'. Um exemplo é chamar uma de mamãe e a outra de 'mami'. Outro caso é uma questão de acento: uma é máma e a outra é mamá. De qualquer forma, o nome adotado à outra mãe - ou à parceira da mãe - não importa em si mesmo. Mas ele indica o lugar simbólico que ela ocupa naquele laço, podendo ou não constituir-se como familiar. Ainda que haja significantes semelhantes - tal como máma e mamá - as funções a ser desempenhadas pelas parceiras não devem ser iguais.

\footnotetext{
257 DONOVAN (2000) apud HERRERA, F., op. cit.

${ }^{258}$ DONOVAN (2000) apud id., ibid.

${ }^{259}$ HERRERA, F., op. cit.
} 
Kamers $^{260}$, psicanalista de orientação lacaniana, afirma que "as funções parentais, ao consistirem em funções simbólicas e inscritas na cultura, implicam necessariamente a presença de um outro de "carne e osso" que possa encarná-las; o que pressupõe uma transmissão da cultura e a introdução da criança na ordem societária, portanto, sua introdução no campo da palavra e da linguagem. Assim, a transmissão implica uma ordenação simbólica que delimita lugares, de modo que a categoria dos pais defina diretamente a categoria de filho".

Em um dos encontros da Famílias Gays e Lésbicas em Barcelona se tratou do tema da terminologia uma vez que uma mulher manifestou estar preocupada porque seu filho chamava de mamãe só a sua parceira e a ela a chamava pelo nome. As outras mulheres presentes tentaram reconfortá-la e afirmaram que o modo como o filho ou filha chamava suas mães não tinha tanta importância desde que [as parceiras] soubessem que as duas eram suas mães. No entanto, conforme visto acima, tal preocupação não era tão infundada assim. A maneira pela qual o filho se dirige à parceira da mãe indica o lugar simbólico que esta tem/ocupa na economia psíquica do infante. É necessária uma escuta analítica mais aprofundada do discurso da criança para se ter acesso ao lugar, muitas vezes inconsciente, atribuído à outra mulher que convive com o par mãe-criança.

De acordo com Weston ${ }^{261}$, a preocupação sobre como chamará um filho de um casal homossexual a suas mães ou pais está curiosamente extendida ao mundo heterossexual. Para Weston, tal inquietação implica que os homossexuais moldam suas relações de paternidade e maternidade segundo a divisão de gênero heterossexual. Todavia, em Barcelona e Santiago , esta é uma preocupação que está presente entre as mulheres lésbicas sem estar relacionada com a clássica divisão de gênero.

Cadoret $^{262}$ sustenta que uma criança pode inclusive utilizar o mesmo termo, por exemplo 'papai', para chamar a seus dois pais. Isto se deve a que a criança pode não perceber diferenças - em nível de atitudes, sexo, ou de tarefas que ambos pais realizam - que justifiquem chamá-los de maneiras diferentes (grifos nossos). As

\footnotetext{
${ }^{260}$ KAMERS, M. - "As novas configurações da família e o estatuto simbólico das funções parentais". In: Estilos da Clinica, 2006, vol. XI, n21, SP, IP-USP.

${ }^{261}$ WESTON (1991) apud HERRERA, F., op. cit.

262 CADORET (2003) apud HERRERA, F., op. cit.
} 
mulheres entrevistadas em Barcelona e Santiago, preferem utilizar nomes distintos para cada mãe já que, ainda quando as duas cumpram as mesmas funções, seguem sendo pessoas diferentes.

Quanto à função dos primeiros cuidados com a criança, correspondente à função materna, o estudo de Herrera aponta que as mães planejam estratégias para dividir os cuidados da criança.

As parceiras costumam dividir entre si as tarefas relacionadas com a criação dos filhos, inclusive algumas mulheres lutam pelos espaços de cuidado. No caso de L. e C., é L., a 'outra mamãe' que fica em casa tomando conta de Mi. durante o dia, enquanto C., a mãe biológica, é a que trabalha ${ }^{263}$.

Para que os cuidados possam ser divididos, a mãe biológica deve deixar um espaço para a 'outra mamãe'. Isto é importante sobretudo no início, quando a criança depende fisicamente de sua mãe biológica em aspectos tão simbólicos como sua alimentação. A 'outra mãe' busca participação ativa em todo o processo de concepção da criança, como estratégia para sua inserção, desempenho e legitimação da sua função parental.

O estudo de Herrera ${ }^{264}$ aborda ainda o que acontece quando o casal se separa. A separação de um casal quando há filhos em comum é sempre dolorosa e complicada. Além do emocionalmente forte que é este processo para todos os envolvidos, devem-se resolver assuntos como com quem viverão os filhos, regimes de visita, pensões alimentícias, entre outros. No caso de um casal de lésbicas com filhos este assunto é ainda mais delicado. Segundo mostra a pesquisa, quando a unidade familiar se dissolve, cada mãe deve lidar não só com a dor da perda, mas também com a falta de regras e regulação legais. A que fica em uma posição mais desvantajosa é a 'outra mamãe'. Ela fica totalmente desprotegida e à mercê da vontade da mãe biológica de permitir sua continuação na criação do filho.

\footnotetext{
${ }^{263}$ HERRERA, F. (2004), op. cit.

${ }^{264}$ HERRERA, F. (2004), op. cit.
} 
Para as entrevistadas, em seus discursos fica explícito que a relação da 'outra mãe' com os filhos vai mais além da relação do casal e se espera que consiga sobreviver a uma ruptura amorosa.

Dunne $^{265}$ sublinha o peso da conexão biológica da mãe com o filho ante uma eventual separação. Dá como exemplo o caso de duas mulheres que decidem realizar um projeto de maternidade compartilhada onde cada uma tem um filho biológico. Em caso de separação, a regra da conexão biológica é inquestionável e, em geral, cada uma seguirá seu caminho com seu próprio filho.

No caso da relação lésbica, uma vez que se rompe a parceria conjugal, tende-se a lesionar o vínculo parental entre a mãe não biológica e o filho. A falta de respaldo legal para este vínculo e o peso simbólico da biologia fazem com que a figura da 'outra mamãe' seja muito vulnerável.

Para concluir, ante o exposto, percebe-se que ainda é delicada a construção de relações familiares a partir de uma identidade sexual estigmatizada e considerada contraditória com a vida familiar. A sensação de vulnerabilidade ante a sociedade das 'outras mamães' e também dos pais homoparentais faz com que a forma de perceber, construir e apresentar a relação com seus filhos esteja marcada pela busca de aceitação social e legitimação, assim como fora e continua sendo em relação à própria identidade sexual.

Nos casais lésbicos, ainda quando a falta de reconhecimento legal do vínculo mãe-filho tem efeitos concretos e dolorosos, as 'outras mamães' não se sentem suficientemente fortes para reivindicar seus direitos, talvez por existirem aspectos mais básicos que ainda não foram resolvidos, como a discriminação à identidade lésbica e o reconhecimento da relação de casal.

A ideia de maternidade para essas mulheres, principalmente no caso e reprodução assistida, não é algo dado - pela natureza - , mas algo que deve ser construído através da gestação, do cuidado e da criação - pela ação humana. Da mesma forma, as 'outras mães' outorgam aos cuidados dedicados ao filho o poder de constituir a relação de parentesco.

${ }^{265}$ DUNNE (2000) apud HERRERA, F., op. cit. 
Todavia o sangue, a comida e a experiência de portar o feto têm um forte peso simbólico na constituição dos laços de maternidade e paternidade. As mulheres entrevistadas privilegiam métodos, como a inseminação, que lhes permitam transmitir seu sangue a seus filhos; suas parceiras valorizam que seus futuros filhos se pareçam com sua companheira e, por sua vez, as mães temem a informação genética que o progenitor pode transmitir. Assim mesmo, quando o casal se separa o filho fica com sua mãe biológica.

A maternidade lésbica combina elementos tradicionais com elementos transgressores. Por um lado se deixa entrever o peso do sangue e do biológico na constituição dos vínculos e se prioriza a maternidade em casal (em parceria). Por outro, constrói-se um discurso sobre a importância dos cuidados e dos afetos para legitimar os vínculos não validados pelo sangue e questiona-se a diferença de sexo na base da família nuclear.

Nos casais de mulheres que decidem ter filhos juntas, uma delas não terá o vínculo biológico com seu filho e sua função parental, por conseguinte, deverá legitimarse, principalmente, através do simbólico - do discurso da mãe que aponte um lugar parental para a parceira - e do social - do reconhecimento dos outros familiares, dos amigos. Do ponto de vista analítico, sabe-se que disso dependerá o reconhecimento e o lugar que atribuirá a criança à outra figura do par conjugal -, seja o par feminino ou masculino. Todavia, no caso do casal masculino, um outro aspecto estará envolvido, visto que o pai - biológico ou adotivo - deverá, primeiramente, ser investido nesse lugar por aquela figura que ocupa o lugar e a função de mãe para a criança, para, posteriormente, haver possibilidade de investir o parceiro do pai de uma função parental. 


\section{CONSIDERAÇÕES FINAIS}

Neste trabalho, percorreu-se o trajeto da orientação e identidade sexual nos campos médico-psicológico e socioantropológico, passando pela constituição do sujeito e sexualidade em psicanálise. Em seguida, percorreu-se o caminho da formação da instituição familiar, sua formação histórica e social, bem como seu aspecto psicanalítico até se chegar à sua dinâmica interna através da análise das funções parentais do ponto de vista psicanalítico, para, finalmente, ser investigado o desempenho das funções parentais nos casais homossexuais com filhos.

Nesse percurso, foi pontuada a diferença entre a identidade de gênero e a identidade sexual, duas categorias distintas que se referem, respectivamente, à autoidentidade do sujeito enquanto pertencente ao sexo anátomo-biológico ou não - sentirse homem, masculino ou mulher - e à identidade definida pela orientação sexual quanto ao objeto de desejo sexual - heterossexual, em caso de escolha pelo sexo oposto, homossexual, em caso de mesmo sexo e bissexual, em caso de sujeitos que se relacionam com ambos os sexos. Viu-se que a identidade de gênero e a identidade sexual são categorias independentes. A partir do estudo da identidade homossexual, percebe-se que os estereótipos que compõem o imaginário social em torno da figura do homossexual efeminado não recobre toda a miríade de variações da identidade homossexual. É possível haver um homossexual com comportamentos ditos masculinos bem como uma homossexual com comportamentos socialmente femininos - ou seja, homossexuais cuja identidade e atributos de gênero conformam-se à realidade anatômica e aos 'semblantes', conforme a denominação lacaniana, que são imagens ideais difundidas pela cultura.

Da questão da identidade sexual bem como de suas concepções no campo psicanalítico, percorreu-se a questão da família, sua história, valores, estruturação e dinâmica, de modo a contextualizar o fenômeno das famílias homoparentais.

Foi visto que, diante da variedade de formações e composições denominadas de família na maior parte das culturas e sociedades humanas, o denominador comum passa a ser os vínculos de aliança e parentesco, sobrepostos até mesmo aos vínculos 
biológicos. Dessa forma, a família nuclear, a partir do século XVIII, torna-se uma referência normativa, um modelo a ser seguido e incentivado por médicos, juristas, psicólogos e outros profissionais representantes dos discursos disciplinares, que prosseguiu ao longo dos tempos. como uma referência marcante, alçada à condição de arranjo ideal (em detrimento dos demais) e não como uma possibilidade dentre outras. Conforme Uziel ${ }^{266}$ afirma, a ideia de uma família natural, formada por pai, mãe e filhos, prossegue. Ou seja, continua-se a utilizar o ideal heterossexista como ideal de família e a família homoparental tem que seguir, de alguma maneira, tais parâmetros tanto para se sustentar enquanto família - grupo vincular afetivamente "indissolúvel" e "seguro" , como para conseguir reconhecimento social e jurídico. O que implica que nem se trata de uma família tão 'estranha' ou 'diferente', mas também não se trata de uma família como outra qualquer, isto é, modelar, ideal, a mais frequente, normatizada.

Então, o que das famílias normatizadas, heterossexuais, permanece nas famílias homoparentais? O exercício das funções parentais? O desempenho dos papéis? É possível uma singularidade aí? E até que ponto ela é culturalmente tolerável?

A família, como visto, se constitui como uma estrutura psíquica e simbólica, em que um elemento fundamental intragrupal necessita existir para que se configure e possa continuar existindo como tal: a lei simbólica; a interdição do incesto - que demarca o lugar das gerações e de cada membro, garantindo a autoridade dos ascendentes sobre os descendentes e a transmissão de valores culturais primordiais necessários para as trocas e estabelecimentos de laços afetivos e sociais. Isso, em nossa cultura, precisa ser mantido e, na medida do possível, garantido para que se mantenha essa estrutura tida como célula primordial de constituição e desenvolvimento do sujeito - ao mesmo tempo, singular e social (e político inclusive), não importando que sexo tenha aqueles personagens que vão encarnar essas figuras de referência para o pequeno sujeito a se constituir.

Quanto ao grande temor - sintomático e fantasístico, a nosso ver - do apagamento da diferença sexual nos casais homossexuais, trata-se, provavelmente, de formações derivadas do temor à diferença, à ameaça que o "novo" - se é que o é tão novo assim - traz às tradições, enquanto ameaça de dissolução, enquanto também

\footnotetext{
${ }^{266}$ UZIEL, A.P. (2007) Homossexualidade e Adoção. RJ: Garamond, 2007.
} 
fantasia homofóbica por parte até mesmo de alguns psicanalistas que se 'agarram' fortemente a certas ideias e a certos referenciais, como forma, talvez, de assegurar a própria 'identidade', ou mesmo tentar fixá-las e estabilizá-las, aplacando a angústia da incerteza, de morte, destruição, ou de perda de si. Entretanto, como visto, assim como "o homossexual" foi uma figura criada pelo próprio campo médico-psicológico, enquanto categoria patológica como forma de identificar um 'inimigo', um 'diferente',- tal como Foucault desmascara essa estratégia dos "discursos de poder",- e, quando se desmitifica essa figura, ela se torna mais tolerável, o mesmo acontece quando esses homossexuais demonstram desejar e serem capazes de criar filhos e constituir uma família com outro do mesmo sexo. O preço a se pago, a priori, pela condição/identidade homossexual - a esterilidade - passa a ser questionado, contestado e revogado, provocando uma desestabilização naqueles que sustentam uma determinação seja natural, biológica e até mesmo religiosa, sagrada da instituição familiar e, por generalização indutiva, da cultura. Os novos pais gays e lésbicos, no entanto, não pretendiam questionar os dois grandes interditos fundadores das leis do parentesco: proibição do incesto, interdito do distúrbio das gerações.

Para lésbicas e gays, todavia, a conjugalidade e a parentalidade parecem não ter sexo, gênero ou orientação sexual, sendo concebidas apenas como materialização do amor e da busca de felicidade e alegria de viver.

Enquanto psicanalistas, será que temos algum 'poder/saber' definitivo do que é uma família, um pai ou uma mãe? Ou será que as próprias teorias analíticas estão fundamentadas em pressupostos culturais 'naturalizantes'?

Viu-se também que, mais disjuntas ainda estão as categorias parentais - pai e mãe - do sexo anatômico, tendo em vista que, enquanto funções psíquicas, tal qual colocado pela psicanálise lacaniana, elas obedecem a outros elementos determinantes que não necessariamente se coadunam com o sexo biológico daquele que encarna e exerce a função para a criança. Se a função materna está relacionada ao Outro, enquanto campo de significantes constituinte do eu imaginário do sujeito, de cifração de sua demanda, alienando-a ao desejo do Outro, e a paterna ao elemento significante que interdita, limita e barra o gozo desse Outro, ou seja, o significante Nome-do-Pai, que representa a Lei simbólica, trata-se de funções simbólicas, carregadas de afeto, 
significativas e de efeitos importantes, constituintes da estrutura subjetiva, mas primordialmente abstratas, e, como tais, passíveis de serem 'desempenhadas' por qualquer ser falante, de linguagem, que tenha um vínculo libidinal e simbólico com o sujeito e que, consciente e inconscientemente, instituído pelo sujeito a esse lugar, transmita e simbolize o desejo, que aponta para os ideais, e a lei que barra o gozo e simboliza a castração, dando algumas possibilidades (mas não todas) para o sujeito lidar com o Real do sexo e da morte.

De forma geral, o pai, na perspectiva cultural e de forma imaginária, antes de o ser, é um homem, quer dizer, possui uma identidade masculina constituída em torno da negatividade de três aspectos: da passividade, da feminilidade, da homossexualidade. Do ponto de vista psicanalítico, o sujeito homem é aquele que está referenciado ao falo simbólico e totalmente submetido à norma fálica e ao gozo dito fálico.

O nascimento de um filho, assim como a maternidade, constitui um marco na trajetória de um homem. Mas podemos pensar se a paternidade se origina no momento de nascimento de um filho ou na adoção de uma criança? Se a mãe é sempre certa e o pai, incerto, este último, do ponto de vista psicanalítico, se constitui como um nome. Como tal, o pai é aquele a quem a mãe assim o nomeia. Mesmo antes do nascimento, na grande maioria das vezes, a mãe, por um ato de linguagem, elege o parceiro como o pai do filho. O homem, ou parceiro nomeado, por sua vez, por motivos conscientes e inconscientes, pode aceitar ou não ocupar este lugar e, a partir da convivência com o filho, exercer este papel.

Acontece que, assim como diferentes atores podem interpretar um mesmo personagem de distintas maneiras, cada homem, enquanto pai, exerce seu papel de modo singular. Ou seja, cada um poderá ocupar o lugar de pai e exercer seu papel a partir do que pôde receber enquanto filho, ou seja, de Ter podido se reconhecer neste lugar, enquanto devedor de uma dívida para com sua família de origem, para com seu próprio pai.

A partir da distinção entre o pai real - o ator , o pai imaginário - o personagem e o pai simbólico - o significante, a palavra que o designa -, torna-se possível o entendimento de que uma mulher possa, de repente, numa situação de casal de mulheres, ocupar o lugar e exercer o papel e a função de pai de um filho ou uma filha 
ao lado de outra mulher. Segundo visto na teoria psicanalítica, não é a pessoa real, de um homem, por exemplo, a condição necessária para fazer operar a função fundamental para a constituição subjetiva, que é a função paterna, mas sim o nome que o designa apontado pela mãe, Outro primordial, que aponta para um terceiro a função de dar o nome do pai que organiza para o sujeito a estrutura de sua filiação. A pessoa a ocupar o lugar de pai real ou a imagem do pai, seu semblante, exercendo este papel, quando investida pela mãe faz operar a função paterna instalada pelo significante, instaurando a lei simbólica que interdita o gozo do sujeito com a mãe. Portanto, é a partir da linguagem que a função paterna pode operar. É o discurso materno, porém, que deve permitir e apontar para aquele (ou aquela) que fará a lei. O sujeito que se predispõe a ocupar tal lugar, precisa fazer crer e valer a efetividade dessa função de forma a operacionalizá-la. Em outras palavras, é desejável que a pessoa que se imbui da tarefa de exercer a paternidade de uma criança possa, por exemplo, fazer a função de pôr limites aos desejos do filho, como forma de imaginarizar a função simbólica da lei.

Seja num casal de homens ou num casal de mulheres, as duas funções parentais podem ou não estar presentes e operantes, assim como em qualquer outro casal de homem e mulher. Como visto, a maternidade e a paternidade não depende do ato biológico de tornar-se pai ou mãe, mas de ocupar esses lugares e papéis simbólicos para uma criança, colocando-a no lugar de filho. Não fosse dessa forma, as adoções de criança seriam impossíveis. Em casos de família monoparental, onde apenas um dos membros, em geral a mulher, do casal parental está presente, ambas as funções podem estar presentes no mesmo sujeito, ou até mesmo, a função paterna pode estar referenciada a um terceiro, para além da relação do sujeito infante com a mãe.

Mostrou-se ao longo do trabalho, porém, ser de extrema importância que ambas as funções, paterna e materna, sejam elas desempenhadas por um homem e uma mulher, respectivamente, sejam por duas mulheres ou por dois homens, estejam presentes e operantes na constituição subjetiva de uma criança. É só a partir destes dois lugares simbólicos que o lugar de filho pode ser colocado e ocupado por um sujeito que, futuramente, poderá ser também um pai ou uma mãe. E, vale reafirmar, essas funções não dependem do sexo, gênero, orientação ou identidade sexual de quem vai 
exercê-la. Tampouco essas funções são equivalentes aos papéis, aos semblantes de pai ou de mãe, histórica e socioculturalmente determinados. É a partir da efetividade das funções - psíquicas - materna e paterna que os determinantes socioculturais, para um determinado indivíduo e sujeito, terão suas influências, através da socialização, da escolarização, da mídia, da profissionalização, entre outras. Ou seja, o sujeito faz suas escolhas na vida e na cultura a partir das suas referências parentais - conscientes ou inconscientes, negadas ou admitidas.

Afirmar que um casal homoparental não possui condições para criar um filho meramente pela orientação sexual dos pais, seria o mesmo que usar este critério para julgar a competência profissional de alguém, sua capacidade para gerenciar conflitos, seu gosto por comida, gênero de filme. Funções parentais e sexualidade são esferas distintas da subjetividade que se cruzam por uma contingência. A reprodução, muito atrelada à sexualidade, pode ser um dos fatores que dêem sentido à proximidade dessas duas esferas, bem como à conjugalidade, a afetividade. São aspectos comuns, como poderíamos encontrar se buscássemos em qualquer outra relação.

É preciso tomar consciência das transformações que estão ocorrendo nos sujeitos, na cultura e na sociedade, ao que se refere à família e à homossexualidade, sendo preciso ampliar o leque de questionamentos a respeito das relações que se podem estabelecer entre a forma de organização da sociedade e o lugar de afeto e esta expressão da sexualidade. É preciso desconfiar da facilidade em relacionar as duas esferas. O sentido de discutir sobre a homossexualidade dos pais não está dado.

A pertinência em se tratar de homossexualidade quando o tema é família não tem uma resposta simples. É fato que hoje homossexuais ocupam não apenas o lugar dos filhos, mas o de pais, na estrutura familiar. A discussão a respeito não inaugura essa realidade social, dá apenas visibilidade a tal condição e a inclui na pauta da conquista de direitos, concorrendo para a extensão da concepção de entidade familiar.

Quanto à experiência dos casais homossexuais com filhos, é possível pensar que em alguns depoimentos de um dos membros de casais homossexuais, houve a menção de temores em relação aos olhares enviesados que os discriminam. Eles dizem pelos filhos que os mesmos não teriam problemas com a conjugalidade dos pais, caso não fossem vistos como estranhos e como produtos de uma ilegalidade. Mas 
talvez tal preocupação tende a se dissipar ou se minimizar com as atuais mudanças em relação a sentenças jurídicas - jurisprudências - a favor da adoção e do reconhecimento das uniões homossexuais, o caminho inverso de uma mudança social, que, em tese, costuma levar a alteração da lei para se adequar àquela, por ter- se tornado desatualizada. No caso da homoparentalidade, as decisões judiciais, bem como suas repercussões na mídia provocam mudanças de opiniões e auxiliam na maior tolerância a essa nova configuração familiar, uma vez que esta vai perdendo a imagem de ilegalidade ou imoralidade.

A discriminação dessas crianças, se não causa danos psíquicos (não temos constatações empíricas), certamente produz muito sofrimento, o que é inadmissível em uma sociedade libertária que, a rigor, deveria potencializar uma expressão mais livre da sexualidade e dos afetos. É inútil prenunciar destinos funestos, quando se trata de relações complexas que envolvem múltiplas dimensões psicossociais, a não ser que haja empenho na manutenção de uma consciência moral rígida que nega o inconsciente, como instância que abriga processos psíquicos flexíveis - e, muitas vezes, inacessíveis - e que, por isso mesmo, desafiam e transgridem a moral vigente em diferentes aspectos.

Precisamos acreditar que a rapidez com a qual a sociedade, e mais particularmente a família, tem se transformado possa, igualmente, produzir mudanças de mentalidade. Só assim seria possível eliminar os temores e as ameaças (re)apresentados hoje pelos sujeitos da homoparentalidade. Se os preconceitos são prejudiciais a estes sujeitos, são também a todos nós. Afinal, negar o diferente é excluir uma parte de si mesmo. Provavelmente aquela mais importante, ou com a qual o sujeito tem maior dificuldade em lidar.

Costuma-se polemizar sobre a influência que possa vir a ter - ou não - a orientação sexual dos pais sobre seus filhos ou filhas. A pergunta a respeito é: importa a orientação sexual dos pais? (e se é assim, de que forma?) Os efeitos sociais derivados da heteronormatividade limitam as considerações teóricas feitas a propósito do exercício parental não inscrito em tal modelo. As relações não-heterossexuais seguem como uma prática estigmatizável porque reconhecemos os perigos políticos que implicam assinalar que os filhos ou filhas com pais não-heterossexuais, possam 
ampliar os umbrais de permissividade a respeito de seus desejos eróticos ou de identidades de gênero. Porque o argumento negativo segue sendo o mesmo afinal de contas, a não-heterossexualidade. Inevitavelmente, os filhos ou filhas compartilham da maioria dos privilégios e preconceitos sociais que se associam a seus pais. Porém se o preconceito social fosse tomado como o critério para restringir os direitos de parentalidade a casais não-heterossexuais, só um limitado grupo de adultos seria elegível para exercê-la. Passar o umbral do que o pensamento liberal tem considerado como "direitos negativos" (como sustenta Meccia, a partir de considerar a homossexualidade como uma prática confinada À ordem da intimidade e do privado, a mesma não é nem deve converter-se às claras à intervenção estatal nem religiosa. É neste sentido que o direito À homossexualidade integra a lista dos "direitos negativos"; isto é, o direito a não ser molestado sempre e quando não se incitem atos de violência ou considerados impudicos publicamente) para considerar a importância de exercer livremente o direito a ser pais a casais não heterossexuais, implica fortes considerações que excedem inclusive o campo do jurídico. Romper com o essencialismo da heteronormatividade, e seus efeitos sociais discriminatórios, é seguramente uma das primeiras tarefas a analisar.

A paternidade foi construída historicamente, numa estreita vinculação com 0 modelo de ser homem e, consequentemente, de ser macho, na tentativa de estabelecer formas ideais de identidade de gênero e fortalecer os dispositivos de controle sobre a mulher, sobre a sexualidade e sobre a família.

O distanciamento da homossexualidade das relações de parentesco e da possibilidade de constituição familiar aumentou ainda mais o controle homofóbico acerca desta experiência, produzindo representações negativas para a paternidade homossexual ao aferir a essa vivência suspeitas de corrompimento sexual, aberração, anomalia (UZIEL $\left.{ }^{267}, 2007\right)$.

A paternidade se apresenta, para os sujeitos da pesquisa, como possibilidades variadas: como forma de transmissão de valores e crenças e descendentes, como cumprimento de missões e designações divinas, como busca de reconhecimento social, como cumprimento de regras culturais, definidas para homens e para mulheres. Diante

${ }^{267}$ UZIEL, A.P. (2007), op. cit. 
de cada uma delas, é possível perceber importantes mudanças na vida de cada sujeito, imputadas pelo aparecimento dos filhos e pela necessidade em reposicionar-se no tecido social e familiar.

As reconfigurações que cada sujeito propõe para suas vidas ainda se dão, entre outros fatores, pela omissão legislativa, que não garante diversos direitos civis a homossexuais, entre eles, o de adoção conjunta. Essa legislação ainda representa dispositivo de controle e vigilância que, legitimando o preconceito e a homofobia, impossibilita que o homossexual tenha acesso aos direitos de filiação que reconhece e à concretização da paternidade a partir de um projeto de adoção.

O debate acerca da sexualidade promovido pelos movimentos sociais atribuiu um caráter político a esta dimensão, colocando nas discussões públicas aquilo que, até então, era atributo de resoluções privadas. A partir daí, as estruturas familiares e identidades sexuais historicamente segregadas começam a receber visibilidade, provocando, inclusive, questões para a academia e para os tramites legislativos.

A atenção aumenta, cada vez mais, em torno da problemática homossexual, apontando para uma necessidade de se ampliar as discussões e reflexões acerca da vivência homoparental.

A crítica à patologização da homossexualidade se torna imprescindível para uma análise ética e politicamente comprometida com a transformação social, mais especificamente com a experiência de homens e mulheres homossexuais.

Tem-se ainda um longo exercício de democracia pela frente e, sobretudo, de respeito à diversidade sexual humana. Esperamos que a psicanálise e a ciência possam estar sempre ativas e articuladas tentando cumprir o papel: buscar os fatos, as evidências, sem se esquecer dos paradigmas epistemológicos que sustentam e constróem suas interpretações e métodos de investigação. Com tais pesquisas, faz-se necessário primordialmente a consideração dos aspectos éticos e do respeito à cidadania de todas as pessoas, sem que se exclua ninguém por conta de sua raça/etnia, credo, gênero, orientação sexual, ou qualquer outra categoria inventada por nós. 


\section{REFERÊNCIAS}

ALBERTI, Sônia (org.) - A Sexualidade na aurora do século XXI. Rio de Janeiro: Companhia de Freud, 2008.

ANDRÉ, Serge. - O que Quer uma Mulher? Rio de Janeiro: Jorge Zahar Ed., s.d.

APPOA (Associação Psicanalítica de Porto Alegre), CALLIGARIS, Contardo. (org.) Educa-se uma criança? Porto Alegre: Artes e Ofícios, 2010

ARÁN, Márcia. - "Políticas do desejo na atualidade: o reconhecimento social do casal homossexual". (Texto extraído da Internet, pelo buscador "Google", abril -2008).

AULETE, Caldas. - Minidicionário contemporâneo da língua portuguesa. Rio de Janeiro: Nova Fronteira, 2004.

BADINTER, Elisabeth. - Um amor conquistado - o mito do amor materno. Rio de Janeiro: Nova Fronteira, 1985.

. - Um é o outro. RJ: Nova Fronteira, 1986.

BALANCHO, L. S. F. "Ser pai: Transformações intergeracionais na paternidade". Análise Psicológica, jun. 2004, vol.22, no.2, p.377-386. Instituto Superior de Psicologia Aplicada, Lisboa, 2004. - Google Acadêmico - Acesso pelo buscador “Google acadêmico”, Revista 'Scielo', em 21-11-2010).

BARBERO, Graciela Haydée. - Homossexualidade e Perversão na Psicanálise - uma resposta aos 'gays and lesbians studies'. São Paulo: Casa do Psicólogo, 2005.

BETTS, Jaime Alberto. "Missão impossível? Sexo, educação e ficção científica". In: APPOA (Associação Psicanalítica de Porto Alegre). CALLIGARIS, Contardo. (org.) Educa-se uma criança? Porto Alegre: Artes e Ofícios, 2010, p.61.

BOZON, Michel. - Sociologia da Sexualidade._São Paulo: Editora FGV, 2006.

BUTLER, Judith. - Problemas de Gênero - Feminismo e subversão da identidade. Tradução: Renato Aguiar. Rio de Janeiro: Civilização Brasileira, 2003. 
CARRARA, Sergio. e SIMÕES, Julio Assis. - "Sexualidade, cultura e política: a trajetória da identidade homossexual masculina na antropologia brasileira". In: Cadernos Pagu. Dossiê: Sexualidades Disparatadas. n.28.Campinas, jan./jun.,2007.

CECARELLI, Paulo Roberto. - "Diferenças Sexuais...? Quantas existem?". In: CECARELLI, P. R. (org.) - Diferenças Sexuais. São Paulo: Escuta, 1999 (b). (Coleção Biblioteca de Psicopatologia Fundamental).

CECARELLI, Paulo Roberto. - "Teorias psicanalíticas da identidade de gênero". In: CECARELLI, P. R. (org.) - Diferenças Sexuais. São Paulo: Escuta, 1999 (a). (Coleção Biblioteca de Psicopatologia Fundamental).

CESAROTTO, Oscar. - O Que é Psicanálise - segunda visão. São Paulo: Brasiliense, 1992. (Coleção Primeiros Passos, vol. 133)

CRUGLAK, Clara. - Clínica da Identificação. RJ: Companhia de Freud, 2001.

DIAS, Maria Berenice. - "A paternidade homoparental". In GROENINGA, G. e CUNHA PEREIRA, R. (ORGS.). - Direito de Família e Psicanálise - rumo a uma nova epistemologia. RJ: Imago, 2003, pp. 269/275

DINIZ, A. G. R.; BORGES, C. A. M. "Possíveis Interlocuções entre Parentesco e Identidade Sexual: Paternidade vivenciada por Homens Homo/Bisexuais". In GROSSI, M.P. et. al. (orgs.) - Conjugalidades, Parentalidades e Identidades Lésbicas, Gays e Travestis. RJ: Garamond, 2007. (Pp. 253-274).

DOR, Joël - O Pai e sua função em Psicanálise. RJ: Jorge Zahar Ed., 1991.

DUMONT, Louis. - O Individualismo - uma perspectiva antropológica da ideologia moderna. Trad. Álvaro Cabral. RJ: Rocco, 1985.

FACCHINI, Regina. - Sopa De Letrinhas -Movimento Homossexual E Produção De Identidades Coletivas Nos Anos 90. RJ: Garamond, 2005 (Coleção Sexualidade, Gênero e Sociedade - Homossexualidade e Cultura)

FERREIRA, Aurélio Buarque de Holanda. - Dicionário Aurélio Básico da Língua Portuguesa. RJ: Nova Fronteira; Folha de São Paulo, 1988.(Obra em 19 fascículos semanais encartados no jornal Folha de São Paulo, de outubro de1994 a fevereiro de 1995). 
FINK, Bruce. - O Sujeito Lacaniano: entre a linguagem e o gozo. Rio de Janeiro: Jorge Zahar Ed., 1998.

FOLHA DE SÃO PAULO - "Maioria é contra adoção por casal gay" - Matéria publicada em 4 de junho de 2010, Caderno 'Cotidiano', p. C1, assinada por Cláudia Collucci. SP: 2010.

FOUCAULT, Michel. - História da Sexualidade, vol. 1: a vontade de saber. Tradução: Maria Thereza da C. Albuquerque. Rio de Janeiro: Graal, 1985.

- História da Sexualidade, vol. 3: o cuidado de si. Tradução: Maria Thereza da C. Albuquerque. Rio de Janeiro: Graal, 1985.

FREUD, Sigmund. - Edição Standard Brasileira das Obras Psicológicas Completas de Sigmund Freud. RJ: Imago, s.d. 1 CD-ROM '

- (1910) 'Um Tipo Especial de Escolha de Objeto Feita Pelos Homens

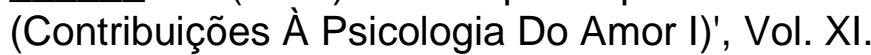

- (1921) 'Psicologia de Grupo e Análise do Ego', Vol. XVIII. Cap. VII - 'A Identificação'.

. - (1923) 'A Organização Genital Infantil', vol. XIX.

. - (1924) 'A Dissolução do Complexo de Édipo', vol. XIX.

- (1925) 'Algumas Conseqüências Psíquicas da Distinção Anatômica entre os Sexos' vol. XIX.

GARCIA, M. R. V.; WOLF, A. G.; et. al. - "“Não Podemos Falhar": a busca pela normalidade em famílias homoparentais". In GROSSI, M. et al. (org.) Conjugalidades, Parentalidades e identidades gays, lésbicas e travestis. Rio de Janeiro: Garamond, 2004

GRAÑA, Roberto B. (org.) - Homossexualidade: formulações psicanalíticas atuais. Porto Alegre: Artes Médicas, 1998. 
GREEN, James N. (org.) - Homossexualismo em São Paulo e outros escritos. São Paulo: Ed. UNESP, 2005.

GROENINGA, Giselle E PEREIRA, Rodrigo da Cunha - Direito de Família e Psicanálise -Rumo a uma Nova Epistemologia. RJ: Imago, 2003.

GROSSI, Miriam Pillar; UZIEL, Anna Paula; MELLO, Luiz. (orgs.) - Conjugalidades, Parentalidades e identidades gays, lésbicas e travestis. Rio de Janeiro: Garamond, 2004.

GROSSI, Miriam Pilar. - "Gênero e parentesco: famílias gays e lésbicas no Brasil". In Revista. Cadernos Pagu, n.21. Publicação do Núcleo de Estudos de Gênero - Pagu, da Universidade de Campinas - Unicamp. Campinas, 2003. (Acessado através do buscador 'Google Acadêmico', palavra-chave: 'família homoparental', em 14/02/2010).

HADDAD, Gisela. - Amor e Fidelidade. SP: Casa do Psicólogo, 2009.

HAMAD, Nazir - A Criança adotiva e suas famílias. RJ: Cia de Freud, 2002.

HANNS, Luis Alberto. - Dicionário Comentado do Alemão de Freud. RJ: Imago, 1996, pp.339.

HEILBORN, Maria Luisa. - Dois é Par - gênero e identidade sexual em contexto igualitário. RJ: Garamond, 2004.

HERRERA, Florencia. - 'A Outra Mamãe': Mães Não Biológicas No Casal Lésbico (Tradução Minha De "La Outra Mamá: Madres No Biológicas En La Pareja Lésbica") In: GROSSI, M.P.; MELLO, L.; UZIEL, A.P. (orgs.) - Conjugalidades, Parentalidades e Identidades Lésbicas, Gays e Travestis. RJ: Garamond, 2007, (PP. 213 - 231).

JULIEN, Phillipe. - "O Desafio de Outra Cultura" In: REVISTA INTERNACIONAL, № 4 - A Clínica Lacaniana - as homossexualidades. [Trad. Procópio Abreu; Editor: José Nazar]. RJ: Companhia de Freud, 2005.

KAMERS, Michelle. - "As novas configurações da família e o estatuto simbólico das funções parentais". In: Estilos $\mathbf{d}^{\mathbf{a}}$ Clinica, Vol. XI, №21, SP, IP-USP 2006,

KEHL, Maria Rita. - A Mínima Diferença - Masculinidade e Feminilidade na Cultura. Rio de Janeiro: Imago, s.d. 
KNUDSEN, Patricia Porchat. - Gênero, Psicanálise e Judith Butler - do Transexualismo à Política. São Paulo, 2007. Tese (Doutorado). Instituto de Psicologia, Universidade de São Paulo.

LA CAUSE FREUDIENNE - Revue de Psychanalyse. Publication de L'École de La Cause Freudienne - Des gays en analyse? - N. 55, Octobre 2003. Paris: Huysmans, 2003.

LACAN, Jacques. - Nomes-do-Pai. [Trad. André Telles; Ver. Técnica Vera Lopes Besset.] RJ: Jorge Zahar Ed., 2005.

"Os complexos familiares na formação do indivíduo" (1938). In Outros Escritos. RJ: Zahar, 2003.

. - O Seminário, livro IV: a relação de objeto (1956-1957). Rio de Janeiro: Jorge Zahar Ed., 1996.

- O Seminário, livro V: as formações do inconsciente. (1957-58). [Tradução de Vera Ribeiro; revisão de Marcus André Vieira]. - RJ: Jorge Zahar, 1999.

- O Seminário, livro IX: a identificação (1961-1962). Recife: Centro de Estudos Freudianos do Recife, 2003. (Publicação não comercial).

. - O Seminário, livro XI: os quatro conceitos fundamentais da psicanálise (1964). RJ: Zahar, 1989.

- O Seminário, livro XX: mais, ainda (1972-1973). Rio de Janeiro: Jorge Zahar Ed., 1985, 2. ed.

LAPLANCHE, Jean e PONTALIS, Jean-Bertrand. - Vocabulário de Psicanálise. São Paulo: Martins Fontes, 1988.

LÉVI-STRAUSS, Claude. - As estruturas elementares de parentesco. RJ: Vozes, 2003.

LIBSON, Micaela. - "Yo opino... Construcciones Discursivas acerca de la Homoparentalidad". In GROSSI, M. et al. (org.) - Conjugalidades, Parentalidades e Identidades Lésbicas, Gays e Travestis. RJ: Garamond, 2007. 
MACHADO, Z. L. - "Masculinidades e violências. Gênero e mal-estar na sociedade contemporânea". In: SCHPUN, M. R. (org.) - Masculinidades. São Paulo: Boitempo Editorial; Santa Cruz do Sul, Edunisc, 2004.

MELLO, Luis. (2005) -"Outras famílias: a construção social da conjugalidade homossexual no Brasil”. In Revista. Cadernos Pagu, n.24, jan./jun. Publicação do Núcleo de Estudos de Gênero - Pagu, da Universidade de Campinas - Unicamp. Campinas, 2005. (Acessado através do buscador 'Google Acadêmico', palavra-chave: 'família homoparental', em 14/02/2010).

MELLO, Luis. - Novas Famílias - conjugalidade homossexual no Brasil contemporâneo. RJ: Garamond, 2005.

MORICI, Silvia. "Homossexualidade: um lugar na História da intolerânca social, um lugar na clínica". In: GRAÑA, Roberto B. (org.) - Homossexualidade: formulações psicanalíticas atuais. Porto Alegre: Artes Médicas, 1998.

NARVAZ, Martha Giudice; KOLLER, Sílvia Helena - "Famílias e patriarcado: da prescrição normativa à subversão criativa". Psicologia Social. Vol.18 no.1 Porto Alegre, U.F.R.G.S., Jan./Apr. 2006. (Acesso pelo buscador "Google acadêmico", Revista 'Scielo', em 21-11-2010).

NASIO, Juan- David. - Lições sobre os sete conceitos cruciais da psicanálise. RJ: Jorge Zahar, 1997, p. 130.

NASIO, Juan-David. - Cinco lições sobre a teoria de Jacques Lacan. RJ: Jorge Zahar, 1993.

NAZAR, José. (ed.) - A Clínica Lacaniana - As Homossexualidades. Revista Internacional, n. 4. Rio de Janeiro: Companhia de Freud, 2005.

NAZAR, Maria Tereza Palazzo (org.). - Psicanálise e Pesquisa: A Função Paterna. RJ: Cia. de Freud: Escola Lacaniana de Psicanálise, 2008. (Psicanalise e Conexões, Vol. 1).

OLIVEIRA, Silvia Broxado. - Loucos por Sexo: Um Estudo sobre a Vulnerabilidade dos Usuários dos Serviços de Saúde Mental para o HIV. Rio de Janeiro, 1998. Dissertação (Mestrado). Instituto de Psiquiatria da UFRJ/IPUB,

PAIVA, Leila Dutra. - Adoção. Significados e possibilidades. São Paulo: Casa do Psicólogo, 2004. 
PARKER, Richard. (org.) - Sexualidades Brasileiras. Rio de Janeiro: Relume Dumará, s.d.

PASSOS, Maria Consuelo. - "Homoparentalidade- uma entre outras formas de ser família". In: Revista Psicologia Clínica, Rio de Janeiro, v.17, n.2, pp.31-40, 2005. (Texto extraído da Internet, no buscador Google, abril 2008).

- "Funções Materna E Paterna Nas Famílias Homoparentais". In: FÉRESCARNEIRO, T. (org.) - Família e Casal: Saúde, Trabalho e Modos De Vinculação. São Paulo: Casa Do Psicólogo, 2007.

PERELSON, Simone. A Parentalidade Homossexual: uma exposição do debate psicanalítico no cenário francês atual. Revista de Estudos Feministas, set-dez, ano/vol. 14, número 3. UFSC/UFRJ, Rio de Janeiro, Brasil, 2006. Pp. 709-730. (extraído da Internet pelo site: www.ufsc.br/ref)

PERSON, E.; OVESEY, L. - "Teorias psicanalíticas da identidade de gênero". In: CECARELLI, Paulo Roberto. (org.) - Diferenças Sexuais. São Paulo: Escuta, 1999. (Coleção Biblioteca de Psicopatologia Fundamental).

PINTO, Elisabeth Batista. - 'A pesquisa qualitativa em Psicologia Clínica e a pesquisa em Psicanálise'. Revista Psicologia USP. São Paulo, v. 15, n. 1-2, pp. 71-80, 2004.

POLI, Maria Cristina - Feminino/Masculino. RJ: Jorge Zahar Ed., 2007. (Coleção Psicanálise Passo-a-Passo, v.76).

POMMIER, Gérard. - "Existe uma distribuição lógica das homossexualidades?". In: Revista Internacional, № 4_- A Clínica Lacaniana - as homossexualidades. [Trad. Procópio Abreu; Editor: José N̄azar]. RJ: Companhia de Freud, 2005.

- Do Bom Uso Erótico da Cólera. Rio de Janeiro: Jorge Zahar Ed., s.d. (Coleção Transmissão da Psicanálise).

PRADO, Marco Aurelio Maximo e MACHADO, Frederico Viana - Preconceito Contra Homossexualidades: a hierarquia da invisibilidade. São Paulo: Cortez, 2008.

PRATES E SILVA, Ana Laura Bicalho. - A Mulher: não existe? Um estudo sobre a feminilidade e suas implicações na clínica psicanalítica. São Paulo, 1996. Dissertação (Mestrado em Psicologia Clínica). Instituto de Psicologia, Universidade de São Paulo. 
PREZOTTO, Zélia e MARCONI, Marina. - Antropologia - Uma Introdução. SP: Atlas, 2007.

RODRIGUEZ, B. C.; PAIVA, M. L. S. C. - Um estudo sobre o exercício da parentalidade em contexto homoparental. Universidade Presbiteriana Mackenzie, São Paulo. Brasil, 2009. (Texto extraído da Internet, buscador 'Google', abril 2010).

ROUDINESCO, Elisabeth. - A Família em desordem. Rio de Janeiro: Jorge Zahar, 2003.

RUBIN, Gayle. - "Pensando sobre sexo -Notas para uma teoria radical da política da sexualidade". In: ABELOVE,Henry; BARALE, Michèle Aina e HALPERIN, David. The Lesbian and Gay Studies Reader. London/New York, Routledge, 1992. Gayle S.Rubin, Publicado pela primeira vez em VANCE, Carole S. (ed.) Pleasure and Danger: Exploring Female Sexuality, 1984.

SARTI, Cinthia Andersen. - "A Família como Ordem Simbólica". In Psicologia USP, v.15, n.3, 2004. São Paulo.

SEVERINO, Antonio Joaquim. - Metodologia do Trabalho Científico. 22. Ed. rev. e ampl. de acordo com a ABNT. SP: Cortez, 2002.

SOLLER, Colette. - O que Lacan dizia das Mulheres. Rio de Janeiro: Jorge Zahar, 2006.

STOLLER, Robert J. - Masculinidade e Feminilidade: apresentações de gênero. Porto Alegre: Artmed, 1993.

TARNOVSKI, Luis. - "Pai é tudo igual?': significado da paternidade para homens que se autodefinem como homossexuais". In: PISCITELLI, A. GREGORI, M. F. e CARRARA S. (orgs.) Sexualidade e saberes: convenções fronteiras. RJ: Garamond, 2004. Pp. 385-414.

TEIXEIRA FILHO, Fernando S.; TOLEDO, L. G. e GODINHO, P. H.. "A homofobia na representação de mães heterossexuais sobre a homoparentalidade". In GROSSI, M. et al. (org.) - Conjugalidades, Parentalidades e Identidades Lésbicas, Gays e Travestis. RJ: Garamond, 2007.

TOLEDO, Luis Celso Castro de. - A família no discurso dos membros de famílias homoparentais. São Paulo, 2008. Tese (Doutorado em Psicologia Social). IP-USP. 
TORRÃO FILHO, Amílcar. - "Uma questão de gênero: onde o masculino e o feminino se cruzam". In Cadernos Pagu, n.24. Campinas jan.jun. 2005.

TURATO, Egberto Ribeiro. - Tratado da metodologia da pesquisa clínicoqualitativa: construção teórico-epistemológica, discussão comparada e aplicação nas áreas da saúde e humanas. Petrópolis, RJ: Vozes, 2003.

UZIEL, Anna Paula. - Homossexualidade e Adoção. RJ: Garamond, 2007.

ZAMBRANO, Elizabeth (2006). "Parentalidades 'impensáveis': pais/mães homossexuais, travestis e transexuais". In Revista. Horizontes antropológicos. Direitos sexuais. Porto Alegre, ano 12, n. 16, jul/dez: publicação do Programa de PósGraduação em Antropologia Social da Universidade Federal do Rio Grande do Sul. (Acessado através do buscador 'Google Acadêmico', palavra-chave: homoparentalidade, em 14/02/2010). 